\title{
Rainfall and Runoff Quantity and Quality Characteristics of Four Urban Land-Use Catchments in Fresno, California, Ociower 1981 to April 1983
}

United States

Geological

Survey

Water-Supply

Paper 2335

Prepared in cooperation with the Fresno Metropolitan Flood Control District
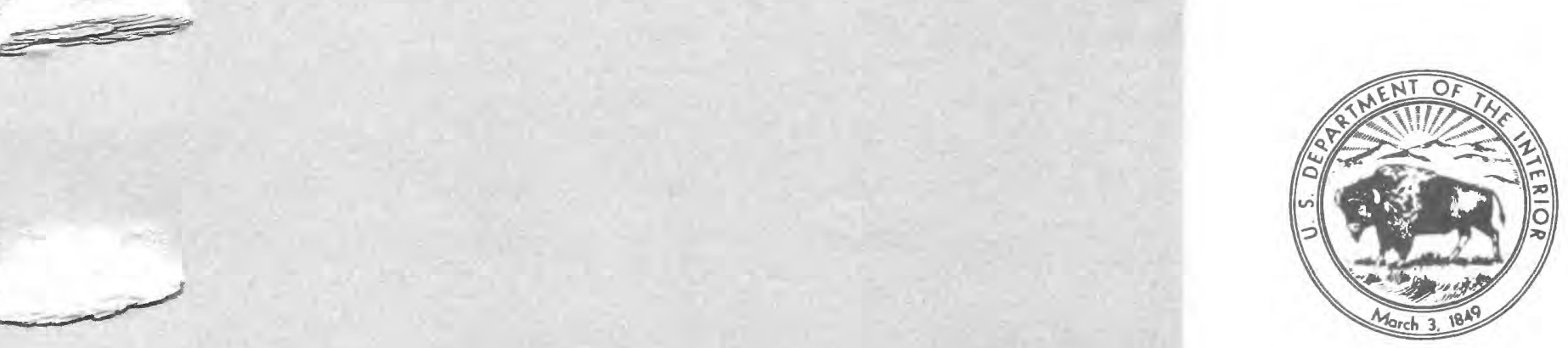


\section{AVAILABILITY OF BOOKS AND MAPS OF THE U.S. GEOLOGICAL SURVEY}

Instructions on ordering publications of the U.S. Geological Survey, along with prices of the last offerings, are given in the current-year issues of the monthly catalog "New Publications of the U.S. Geological Survey." Prices of available U.S. Geological Survey publications released prior to the current year are listed in the most recent annual "Price and Availability List." Publications that are listed in various U.S. Geological Survey catalogs (see back inside cover) but not listed in the most recent annual "Price and Availability List" are no longer available.

Prices of reports released to the open files are given in the listing "U.S. Geological Survey Open-File Reports," updated monthly, which is for sale in microfiche from the U.S. Geological Survey, Books and Open-File Reports Section, Federal Center, Box 25425, Denver, CO 80225 . Reports released through the NTIS may be obtained by writing to the National Technical Information Service, U.S. Department of Commerce, Springfield, VA 22161; please include NTIS report number with inquiry.

Order U.S. Geological Survey publications by mail or over the counter from the offices given below.

\section{BY MAIL}

\section{Books}

Professional Papers, Bulletins, Water-Supply Papers, Techniques of Water-Resources Investigations, Circulars, publications of general interest (such as leaflets, pamphlets, booklets), single copies of Earthquakes \& Volcanoes, Preliminary Determination of Epicenters, and some miscellaneous reports, including some of the foregoing series that have gone out of print at the Superintendent of Documents, are obtainable by mail from

\section{U.S. Geological Survey, Books and Open-File Reports Federal Center, Box 25425 Denver, CO 80225}

Subscriptions to periodicals (Earthquakes \& Volcanoes and Preliminary Determination of Epicenters) can be obtained ONLY from the

\section{Superintendent of Documents \\ Government Printing Office \\ Washington, D.C. 20402}

(Check or money order must be payable to Superintendent of Documents.)

\section{Maps}

For maps, address mail orders to

$$
\begin{gathered}
\text { U.S. Geological Survey, Map Distribution } \\
\text { Federal Center, Box } 25286 \\
\text { Denver, CO } 80225
\end{gathered}
$$

Residents of Alaska may order maps from

\author{
Alaska Distribution Section, U.S. Geological Survey, \\ New Federal Building - Box 12 \\ 101 Twelfth Ave., Fairbanks, AK 99701
}

\section{OVER THE COUNTER}

\section{Books}

Books of the U.S. Geological Survey are available over the counter at the following Geological Survey Public Inquiries Offices, all of which are authorized agents of the Superintendent of Documents:

- WASHINGTON, D.C.--Main Interior Bldg., 2600 corridor, 18 th and C Sts., NW.

- DENVER, Colorado--Federal Bldg., Rm. 169, 1961 Stout St.

- LOS ANGELES, Callfornia--Federal Bldg., Rm. 7638, 300 N. Los Angeles St.

- MENLO PARK, California--Bldg. 3 (Stop 533), Rm. 3128, 345 Middlefield $\mathrm{Rd}$.

- RESTON, Virginia--503 National Center, Rm. 1C402, 12201 Sunrise Valley Dr.

- SALT LAKE CITY, Utah--Federal Bldg., Rm. 8105, 125 South State St.

- SAN FRANCISCO, California--Customhouse, Rm. 504, 555 Battery St.

- SPOKANE, Washington--U.S. Courthouse, Rm. 678, West 920 Riverside Ave.

- ANCHORAGE, Alaska--Rm. 101, 4230 University Dr.

- ANCHORAGE, Alaska--Federal Bldg, Rm. E-146, 701 C St.

\section{Maps}

Maps may be purchased over the counter at the U.S. Geological Survey offices where books are sold (all addresses in above list) and at the following Geological Survey offices:

- ROLLA, Missourl--1400 Independence Rd.

- DENVER, Colorado--Map Distribution, Bldg. 810, Federal Center

- FAIRBANKS, Alaska--New Federal Bldg., 101 Twelfth Ave. 


\section{Rainfall and Runoff Quantity and Quality Characteristics of Four Urban Land-Use Catchments in Fresno, California, October 1981 to April 1983}

By RICHARD N. OLTMANN and MICHAEL V. SHULTERS

Prepared in cooperation with the

Fresno Metropolitan Flood Control District

U.S. GEOLOGICAL SURVEY WATER-SUPPLY PAPER 2335 


\section{DEPARTMENT OF THE INTERIOR}

MANUEL LUJAN, JR., Secretary

\section{U.S. GEOLOGICAL SURVEY}

\section{Dallas L. Peck, Director}

Any use of trade, product, or firm names

in this publication is for descriptive purposes only

and does not imply endorsement by the U.S. Government

For sale by the

Books and Open-File Reports Section

U.S. Geological Survey

Federal Center, Box 25425

Denver, CO 80225

\section{Library of Congress Cataloging-in-Publication Data}

Oltmann, R.N. (Richard N.)

Rainfall and runoff quantity and quality characteristics of four urban landuse catchments in Fresno, California, October 1981 to April 1983 / by Richard $\mathrm{N}$. Oltmann and Mitchael V. Shulters : prepared in cooperation with the Fresno Metropolitan Flood Control District.

p. cm.-(U.S. Geological Survey water-supply paper ; 2335)

Bibliography: $p$.

Supt. of Docs. no.: | 19.13:2335

1. Water quality management-California-Fresno Region. 2. Watershed management-California-Fresno Region. 3. Rain and rainfall-CaliforniaFresno Region. 4. Runoff-California-Fresno Region. 5. Pesticides-Environmental aspects-California-Fresno Region. I. Shulters, M.V., 1950-

II. Fresno Metropolitan Flood Control District. III. Title. IV. Series: Watersupply paper (Washington, D.C.) ; 2335.

TC801.U2 no. 2335

[TD225.F85]

$553.7^{\prime} 0973 \mathrm{~s}-\mathrm{dc} 19$

[363.7'394'0979482] 


\title{
CONTENTS
}

\author{
Abstract 1 \\ Introduction 1 \\ Background 1 \\ Objectives and scope 2 \\ Description of study area 2 \\ Site selection and description 2 \\ Data types and data collection 2 \\ Description of hydrologic conditions during data collection period 4 \\ Data analysis 5 \\ Rainfall and runoff quantity data 5 \\ 1981-83 storm characteristics 5 \\ Rainfall-runoff regression analysis 9 \\ Rainfall-runoff response 13 \\ Rainfall quality samples 13 \\ Comparison of rainfall quality 13 \\ Computation of rainfall constituent loads 14 \\ Runoff quality samples 16 \\ Comparison of catchment runoff quality using discrete sample data 16 \\ Variation of constituent concentrations throughout a storm 19 \\ Regression analysis of constituent concentrations 25 \\ Computation of runoff constituent loads 26 \\ Characterization and regression analysis of constituent event mean \\ concentrations 27 \\ Estimation of land-use mean annual constituent unit loads $\mathbf{3 1}$ \\ Dry-weather runoff samples $\mathbf{3 1}$ \\ Atmospheric dry-deposition quality samples $\mathbf{3 2}$ \\ Street-surface particulate quality samples 32 \\ Comparison of rainfall and runoff quality data 33 \\ Pesticides 35 \\ Comparison with water-quality criteria and standards 37 \\ Summary 38 \\ Selected References 45
}

\section{FIGURES}

1. Index map of California showing Fresno study area 3

2. Photograph of multiple-use stormwater retention basin with inundated baseball diamond 4

3. Map showing location of catchments and rainfall and runoff monitoring sites 5

4. Maps showing monitored catchments 6

5. Graphs showing daily rainfall and storms for which rainfall or runoff quality data were collected 10

6. Graphs showing results of rainfall-runoff regression analysis for each of four monitored catchments 11

7. Flow hydrographs and hyetographs for each of four monitored catchments for a typical storm (November 17, 1981) 
8. Schematic plots of four rainfall constituents that were determined to be significantly different 15

9. Schematic plots showing comparison between catchments for selected constituents using runoff quality data 17

10. Pie diagrams of average concentrations of dissolved major ions for runoff for each of the four monitored catchments 20

11. Typical constituent concentration plots and flow hydrographs for two residential and commercial catchments 21

12. Typical constituent concentration plots and flow hydrographs for industrial catchments 24

13. Graph showing relation of dissolved ammonia plus organic nitrogen and specific conductance using discrete runoff data for multiple-dwelling residential catchment 25

14-16. Graphs showing results of constituent concentration and specific conductance regression analysis for the:

14. Single-dwelling residential catchment $\mathbf{2 6}$

15. Multiple-dwelling residential catchment 27

16. Commercial catchment 28

17. Graph showing computation of runoff load using LOADS program 29

18-20. Graphs showing comparison of constituent event mean concentrations and:

18. Number of days since first storm of rain season 29

19. Number of dry hours since last storm $\mathbf{3 0}$

20. Runoff volume $\mathbf{3 0}$

21. Graph showing comparison of total recoverable lead for atmospheric dry deposition and total dry-deposition material rate with time for the industrial and single-dwelling residential sites $\mathbf{3 3}$

22. Graph showing comparison of constituent atmospheric dry-deposition concentrations with time for the industrial and single-dwelling residential sites $\mathbf{3 4}$

23. Pie diagram of average concentrations of dissolved major ions for rainfall for all monitored rainfall sites $\mathbf{3 5}$

24. Chronological bar chart of diazinon and parathion concentrations in stormcomposite rainfall samples collected at industrial and single-dwelling residential sites 36

25. Time-series plot showing parathion concentration, parathion loading, and storm rainfall totals at the single-dwelling residential site $\mathbf{3 7}$

26-28. Chronological bar charts of:

26. Malathion concentrations in storm composite rainfall samples collected at industrial and single-dwelling residential sites $\mathbf{3 7}$

27. Organochlorine insecticide concentrations in storm-composite rainfall samples collected at industrial and single-dwelling residential sites 38

28. 2,4-D concentrations in storm-composite rainfall samples collected at industrial and single-dwelling residential sites $\mathbf{3 8}$

29. Schematic plots showing comparison of runoff quality data and criteria values for constituents that have primary drinking water standards 39

30. Schematic plots showing comparison of runoff quality data and criteria values for constituents that have secondary drinking water standards $\mathbf{4 2}$

\section{TABLES}

1. Characteristics of the four monitored urban runoff catchments $\mathbf{4 8}$

2. Quality constituents analyzed for in rainfall, runoff, atmospheric dry-deposition, and street-surface particulate samples 49

3. Average monthly rainfall totals for Fresno, California, compared to study period monthly rainfall totals $\mathbf{5 1}$ 
4. Storm characteristics for storms monitored at four catchments $\mathbf{5 2}$

5. Statistical summary of storm characteristics for storms monitored at four catchments $\mathbf{5 7}$

6. Statistical summary of rainfall quality data: industrial site $\mathbf{5 8}$

7. Statistical summary of rainfall quality data: single-dwelling residential site $\mathbf{5 9}$

8. Statistical summary of rainfall quality data: laboratory site 61

9. Results of statistical comparison testing between sites for composite rainfall quality samples 63

10. Rainfall constituent event mean concentrations and loads for storms monitored at industrial site 64

11. Rainfall constituent event mean concentrations and loads for storms monitored at single-dwelling residential site $\mathbf{6 5}$

12. Statistical summary of discrete runoff sample data: industrial catchment $\mathbf{6 7}$

13. Statistical summary of discrete runoff sample data: single-dwelling residential catchment 69

14. Statistical summary of discrete runoff sample data: multiple-dwelling residential catchment $\mathbf{7 1}$

15. Statistical summary of discrete runoff sample data: commercial catchment $\mathbf{7 3}$

16. Results of statistical comparison testing between catchments using discrete runoff quality data $\mathbf{7 5}$

17. Results of linear regression analysis using discrete runoff sample data $\mathbf{7 6}$

18. Constituent storm runoff loads: industrial catchment $\mathbf{7 7}$

19. Constituent storm runoff loads: single-dwelling residential catchment $\mathbf{8 0}$

20. Constituent storm runoff loads: multiple-dwelling residential catchment $\mathbf{8 4}$

21. Constituent storm runoff loads: commercial catchment 89

22. Significant variables affecting constituent event mean concentrations 94

23. Results of linear regression analysis using runoff event mean concentration data 95

24. Statistical summary of runoff event mean concentration data for all monitored catchments 96

25. Estimated average annual constituent unit loads for each land-use type 99

26. Statistical summary of atmospheric dry-deposition quality data: industrial site $\mathbf{1 0 0}$

27. Statistical summary of atmospheric dry-deposition quality data: single-dwelling residential site 101

28. Statistical summary of street-surface particulate quality samples: industrial catchment 103

29. Statistical summary of street-surface particulate quality samples: single-dwelling residential catchment 104

30. Statistical summary of street-surface particulate quality samples: multiple-dwelling residential catchment 105

31. Statistical summary of street-surface particulate quality samples: commercial catchment 107

32. Percentage of runoff load attributable to rainfall load for the industrial and two residential catchments 109

33. Summary of pesticides detected in rainfall, runoff, atmospheric dry-deposition, and street-surface particulate samples $\mathbf{1 1 2}$

34. Statistical summary of pesticides detected in rainfall samples $\mathbf{1 1 3}$

35. Statistical summary of most frequently detected pesticides in runoff for each catchment 114 


\section{METRIC CONVERSION FACTORS}

In this report some measurements are given in inch-pound units and some laboratory data are reported in metric units. Conversion factors from inch-pound units to International System of Units (SI) are given below.

\begin{tabular}{|c|c|c|}
\hline Multiply & By & To obtain \\
\hline acres & 0.4047 & $\mathrm{hm}^{2}$ (square hectometers) \\
\hline $\mathrm{ft}$ (feet) & 0.3048 & m (meters) \\
\hline $\mathrm{ft} / \mathrm{mi}$ (feet per mile) & 0.18948 & $\mathrm{~m} / \mathrm{km}$ (meters per kilometer) \\
\hline $\mathrm{ft}^{3} / \mathrm{s}$ (cubic feet per second) & 0.0283 & $\mathrm{~m}^{3} / \mathrm{s}$ (cubic meters per second) \\
\hline inches & 25.4 & mm (millimeters) \\
\hline mi (miles) & 1.609 & km (kilometers) \\
\hline mi $^{2}$ (square miles) & 2.590 & $\mathrm{~km}^{2}$ (square kilometers) \\
\hline lb (pounds) & 0.4536 & kg (kilograms) \\
\hline lb/acre (pounds per acre) & 1.1208 & $\mathrm{~kg} / \mathrm{hm}^{2}$ (kilograms per square hectometer) \\
\hline
\end{tabular}

Other Abbreviations Used

$\mathrm{meq} / \mathrm{L}$

$\mathrm{mg} / \mathrm{L}$

$\mu \mathrm{g} / \mathrm{d}$

$\mu \mathrm{g} / \mathrm{L}$

$\mu \mathrm{S} / \mathrm{cm}$ at $25{ }^{\circ} \mathrm{C}$ milliequivalents per liter

milligrams per liter

micrograms per day

micrograms per liter

microsiemens per centimeter at 25 degrees Celsius 


\title{
Rainfall and Runoff Quantity and Quality Characteristics of Four Urban Land-Use Catchments in Fresno, California, October 1981 to April 1983
}

\author{
By Richard N. Oltmann and Michael V. Shulters
}

\section{Abstract}

Rainfall and runoff quantity and quality were monitored for industrial, single-dwelling residential, multiple-dwelling residential, and commercial land-use catchments during the 1981-82 and 1982-83 rain seasons. Storm-composite rainfall and discrete runoff samples were analyzed for numerous inorganic, biological, physical, and organic constituents. Atmospheric dry-deposition and street-surface particulate samples also were collected and analyzed.

With the exception of the industrial catchment, the highest runoff concentrations for most constituents occurred during the initial storm runoff and then decreased throughout the remainder of the storm, independent of hydraulic conditions. Metal concentrations were high during initial runoff, but also increased as flow increased. Constituent concentrations for the industrial catchment fluctuated greatly during storms.

Statistical tests showed higher ammonia plus organic nitrogen, ammonia, $\mathrm{pH}$, and phenol concentrations in rainfall at the industrial site than at the single-dwelling residential and laboratory sites. Statistical testing of runoff quality data showed higher concentrations for the industrial catchment than for the two residential and commercial catchments for most constituents. Total recoverable lead was one of the few constituents that had lower concentrations for the industrial catchment than for the other three catchments. The two residential catchments showed no significant difference in runoff concentrations for 50 of the 57 constituents used in the statistical analysis. The commercial catchment runoff concentrations for most constituents generally were similar to the residential catchments.

Although constituent concentrations generally were higher for the industrial catchment than for the commercial catchment, constituent storm loads from the commercial catchment were similar to the industrial catchment because of the greater runoff volume from the highly impervious commercial catchment. Between 10 and 50 percent of the constituent runoff loads for the two residential catchments were attributed to the rainfall load, with the percentages generally considerably less for the industrial catchment.

Event mean concentrations (EMC) for most constituents for all but the industrial catchment were highest for the first two or three storms of the rain season after which they became almost constant. Constituent event mean concentrations for the industrial catchment generally did not show any pattern throughout a rain season. Multiple-regression predictor equations for event mean concentrations were developed for several constituents for all sites. Average annual constituent unit loads were computed for 18 constituents for each catchment.

The organophosphorus compounds, diazinon, malathion, and parathion were the most prevalent pesticides detected in rainfall. Diazinon was detected in all 54 rainfall samples. Parathion and malathion were detected in 49 and 50 samples, respectively. Other pesticides detected in rainfall included chlordane, lindane, methoxychlor, endosulfan, and 2,4-D. Of these, only methoxychlor and endosulfan were not consistently detected in runoff.

\section{INTRODUCTION}

\section{Background}

Fresno Metropolitan Flood Control District (FMFCD) has routed urban stormwater runoff to local manmade retention basins since 1956. The stormwater runoff is allowed to percolate through the underlying soils, thereby (1) disposing of the excess stormwater runoff, and (2) recharging the aquifer which underlies the city of Fresno and is the city's domestic water source.

Public Law 92-500 (the Clean Water Act) and Public Law 93-523 (the Safe Drinking Water Act) set forth national priorities concerning the identification and control of constituents discharged into waters of the United States, and for ensuring the preservation of the Nation's drinking water supplies. Section 208 of Public Law 92-500 identifies urban stormwater runoff as a potential source of pollutants. Section 1421 of Public Law 93-523 decreed the U.S. Environmental Protection Agency (EPA) to establish regulations to control underground injections to protect drinking water sources.

The U.S. Environmental Protection Agency initiated the National Urban Runoff Program (NURP) in order to obtain adequate data to assess urban stormwater effects and to evaluate and develop effective management and control practices. NURP consists of 28 individual urban runoff studies across the country characterizing urban runoff, determining constituent loads, and evaluating effects and control practices. The FMFCD applied for and received a NURP grant from 
EPA through the California State Water Resources Control Board to investigate the potential environmental effects associated with the recharge of urban stormwater runoff in manmade basins. The aquifer that underlies Fresno and receives the urban runoff has been designated by the EPA as a "sole source" aquifer. Only 1 of the other 28 studies investigated ground water as an urban runoff receiving water.

The objectives of the Fresno NURP are to:

1. Determine the character of urban stormwater runoff from different land-use areas, identifying nonpoint sources and concentrations of the constituents.

2. Determine the effects of the retention and recharge of urban storm runoff and its related constituents on the receiving ground water and soils.

3. Identify management practices which insure the safe, controlled disposal of urban storm runoff in retention/ recharge basins.

The FMFCD requested the U.S. Geological Survey to complete objective 1 . Objective 2 is to be completed by the Agricultural Research Service, U.S. Department of Agriculture, and objective 3 is to be completed by Brown and Caldwell Consulting Engineers.

\section{Objectives and Scope}

The objectives of the Geological Survey's study and this report are to:

1. Determine the rate of runoff for the following land uses: industrial, single-dwelling residential, multiple-dwelling residential, and commercial.

2. Identify the type and volume of constituents transported by the runoff water from the four different selected land-use types.

3. Determine the concentrations of nonpoint source constituents (rainfall, atmospheric dry deposition, streetsurface particulate) transported by the runoff water.

4. Determine the time relations between runoff quantity and quality.

The scope of the study included monitoring the quantity, quality, and rate of rainfall and stormwater runoff from four selected land-use catchments during the 1981-82 and 1982-83 rain seasons (October to April). Rainfall and runoff samples were analyzed for inorganic, biological, physical, and organic constituents. Atmospheric dry-deposition and street-surface particulate samples also were collected and analyzed for inorganic, physical, and organic constituents. Of the 28 NURP studies, the Fresno study is one of the few that investigated urban runoff associated with a particular land use; it also includes one of only two industrial catchments investigated under the NURP.

\section{DESCRIPTION OF STUDY AREA}

The city of Fresno is located about 160 miles southeast of San Francisco, California (fig. 1), within the predominantly agricultural San Joaquin Valley. The valley is bounded by the
Coast Ranges on the west and the Sierra Nevada on the east. Fresno is subject to winter storms that move onshore from the Pacific Ocean, over the Coast Ranges, and into the valley. The average annual rainfall for the study area is about 10 inches, nearly all of which falls during October to April.

The topography of the study area is virtually flat with an average gradient of about $8 \mathrm{ft} / \mathrm{mi}$. Because of the flat terrain and lack of adequate water courses through the city, manmade stormwater retention basins have been constructed. The basins average 10 to 15 acres in size, each servicing about $1 \mathrm{mi}^{2}$ of urbanized area. Most of the basins are designed for multiple use, such as parks, athletic fields (fig. 2), and groundwater recharge facilities, during the nonrain season.

The city of Fresno occupies about $150 \mathrm{mi}^{2}$, of which about 27 percent is residential; 4 percent, commercial; and 6 percent, industrial land use (City of Fresno, written commun., April 1978). The remaining land uses consist of agricultural, transportation, public facilities, and vacant land. The city is surrounded by agricultural land with the primary crops consisting of grapes, figs, cotton, alfalfa, peaches, and almonds. Heavy industrial areas do not exist in Fresno, and there is not a predominant industry.

\section{SITE SELECTION AND DESCRIPTION}

Catchments were selected for runoff monitoring for industrial, single-dwelling residential, multiple-dwelling residential, and commercial land-use areas using the following criteria:

1. Catchment land use had to be about 80 - to 90 -percent homogeneous.

2. Catchment had to be 80-percent developed to avoid substantial construction activity during the period of data collection.

3. Catchment had to have a suitable site for an equipment shelter and storm-drain access.

All the selected catchments met the above criteria except the industrial catchment. Of the very few industrial catchments from which to choose, a catchment could not be found that met the 80-percent developed criteria. As shown in table 1 , which is a summary of catchment characteristics, the selected catchment was only 65.8-percent developed.

The locations of the four catchments that were monitored throughout the study period are shown in figures 3 and 4 .

\section{DATA TYPES AND DATA COLLECTION}

Four data types collected throughout the two rain seasons were:

1. Rainfall rate and quality,

2. Runoff rate and quality,

3. Atmospheric dry-deposition quality, and

4. Street-surface particulate quality.

As part of the data collection for runoff rate and quality, dry-weather runoff samples were collected during the summer months at the two residential sites. Rainfall, runoff, 
dry-deposition, street-surface particulate, and dry-weather runoff quality samples were analyzed for inorganic, biological, physical, and organic constituents as shown in table 2 .
All quality samples were analyzed at the U.S. Geological Survey Central Laboratory in Arvada, Colorado, except for biochemical oxygen demand, fecal coliform bacteria,
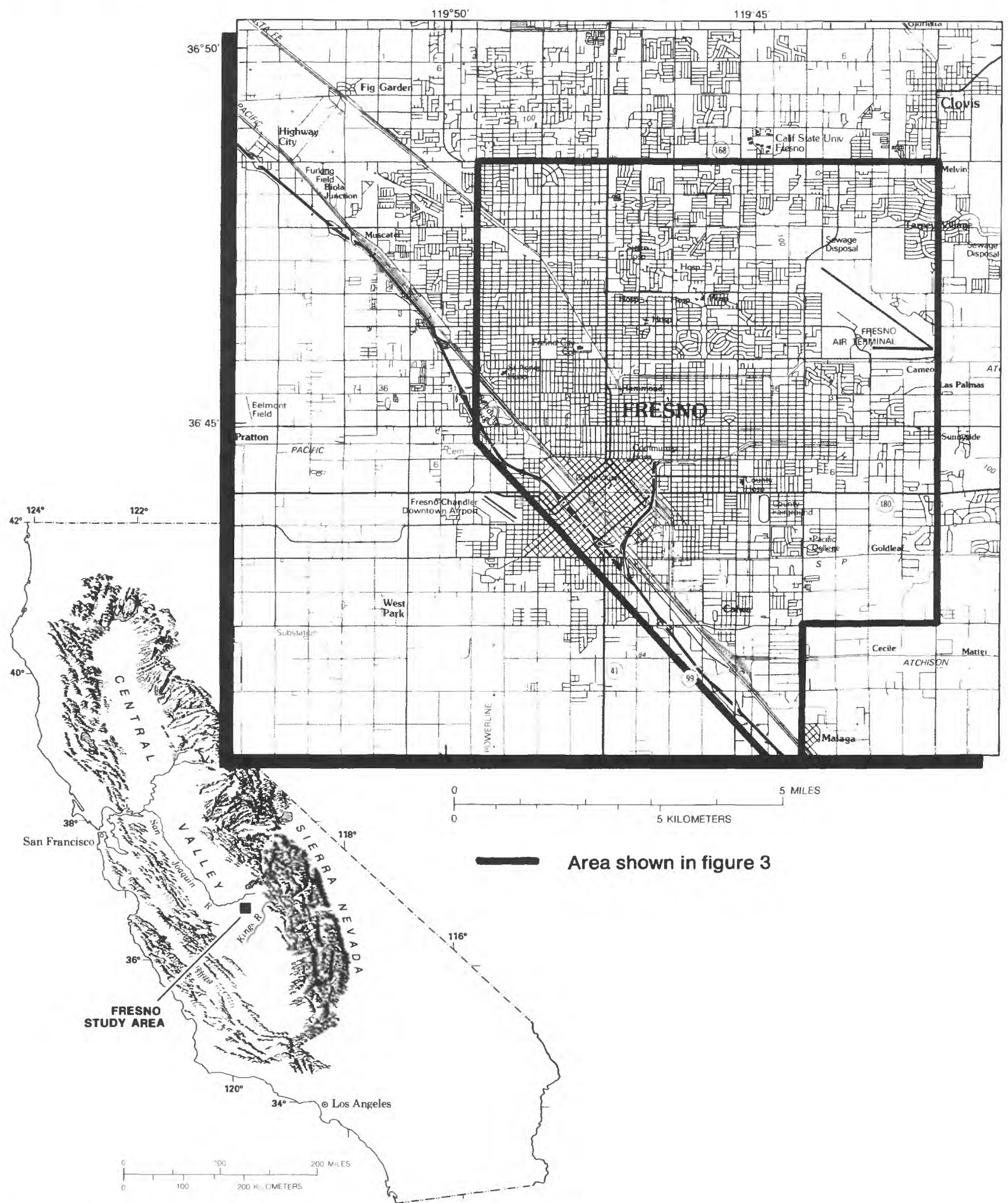

Figure 1. Index map of California showing Fresno study area. 


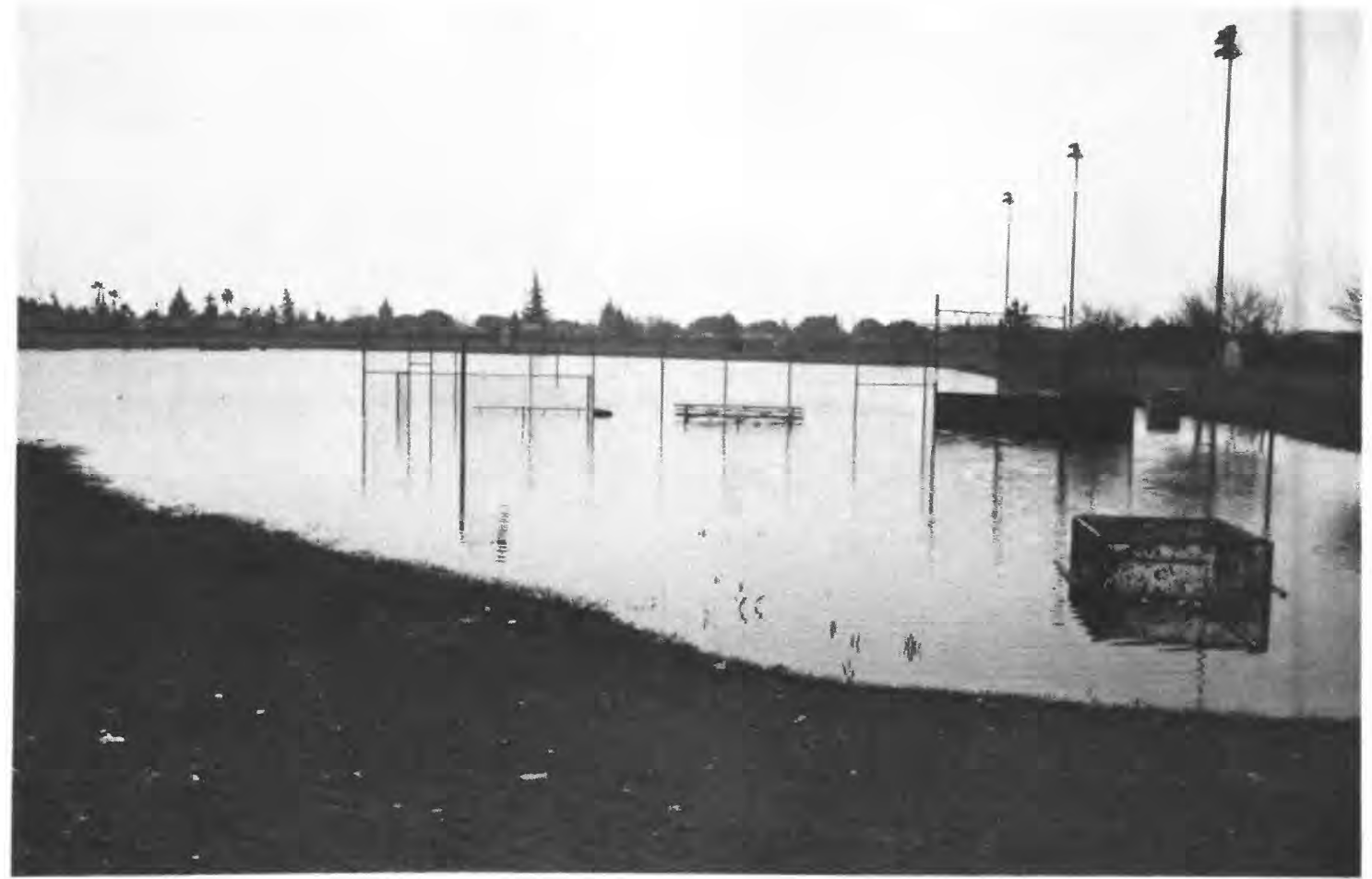

Figure 2. Multiple-use stormwater retention basin with inundated baseball diamond.

suspended sediment, and particle-size analyses. Biochemical oxygen demand samples were analyzed by BSK \& Associates of Fresno, California; fecal coliform bacteria were analyzed by project staff personnel at the project's Fresno laboratory; and sediment and particle-size analyses were performed by the U.S. Geological Survey Sediment Laboratory in Sacramento, California.

Rainfall quality samples were collected as a single bulk sample for an entire storm. Discrete runoff samples were collected throughout storms using automatic sampling equipment; however, organic samples were collected manually using glass containers. For some storms, several discrete samples per site were sent to the laboratory for analysis to provide data on the variation of constituent concentrations with time and flow, and to analyze relations of constituent concentration. For other storms, the automatic sampler was programmed to collect flow-weighted discrete samples (Oltmann and others, 1987) that were composited and sent to the laboratory for analysis for use in computing constituent storm loads.

Specific-conductance data were collected for all discrete runoff samples, including samples collected during storms that did not have samples sent to the laboratory for analysis. Most of the specific-conductance data for the storms that did not have laboratory data were used as input data to the relations of constituent concentrations and specific conductance, in order to estimate constituent concentration. The estimated constituent concentrations then were used to calculate constituent storm loads (refer to "Constituent Concentration Regression Analysis" and "Computation of Runoff Constituent Loads" sections). $\mathrm{pH}$ data were collected for most of the samples.
A discussion of the instrumentation used to collect the above listed data, the data collection and laboratory procedures used, and a listing of the data is given in Oltmann and others (1987).

\section{DESCRIPTION OF HYDROLOGIC CONDITIONS DURING DATA COLLECTION PERIOD}

According to the 104-year rainfall record collected by the National Weather Service, the average annual rainfall at the Fresno Air Terminal is 10.24 inches, of which 9.84 inches ( 96 percent) occur between September and April (table 3) (National Oceanic and Atmospheric Administration, 1981). The rainfall total during the first rain season of this study (1981-82) was near the average (110 percent of average); however, 44 percent of the rainfall total occurred in March (294 percent of monthly average). The second rain season of the study (1982-83) began about a month early with the occurrence of tropical storm Olivia on September 24-25, 1982. This was the start of a recordbreaking rain season that resulted in the September through April monthly rainfall totals exceeding monthly averages with the exception of December, which was 93 percent of the monthly average. The resulting rainfall total for this 8 -month period was 239 percent of average.

During the first rain season, 56 storms occurred with 22 of these resulting in less than 0.10 inch of rain. The remaining 34 storms averaged 0.28 inch of rain. The second rain season had 67 storms through April 14, 1983 (monitoring equipment removal date), with 23 of these resulting in 
less than 0.10 inch of rain. The remaining 44 storms averaged 0.45 inch of rain, or 161 percent of the first rain season storms.

A plot of daily rainfall during the study period as measured by the National Weather Service at the Fresno Air Terminal is shown in figure 5. Also noted in the figure are storms for which rainfall and (or) runoff quality data were collected.

\section{DATA ANALYSIS}

\section{Rainfall and Runoff Quantity Data}

\section{1-83 Storm Characteristics}

Storm characteristics were determined for all storms throughout the study period for each of the four monitored catchments that had complete rainfall and runoff records. The

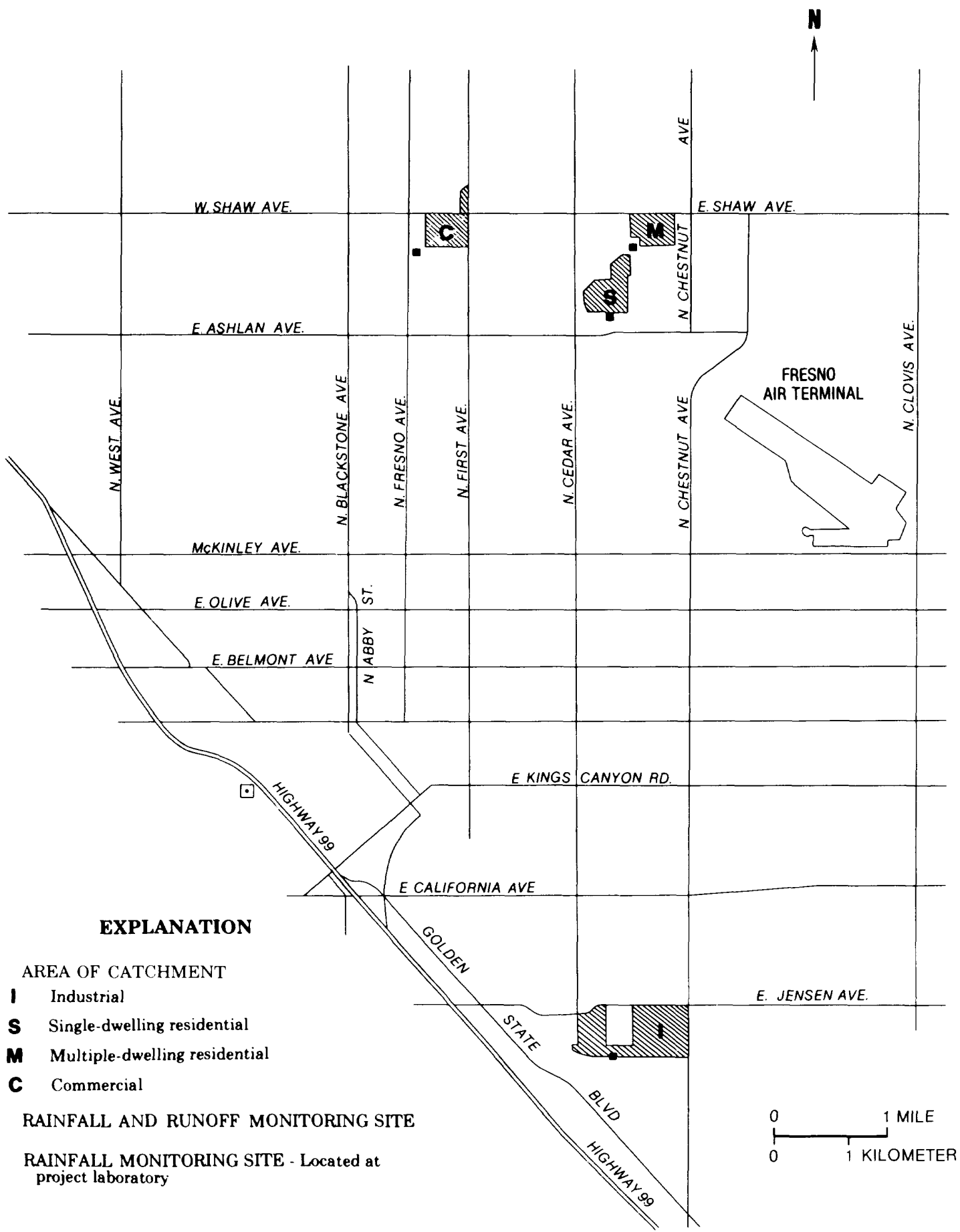

Figure 3. Location of catchments and rainfall and runoff monitoring sites. 
storm characteristics include rainfall total, runoff volume, rainfall-runoff coefficient, maximum 20-minute rainfall total, peak flow, and rainfall and runoff duration. These storm characteristics and two additional variables, number of hours since the previous storm and the number of days since the first storm of the rain season, are listed in table 4 .

Runoff volumes for each storm were computed using the runoff record and the RRLIST computer program documented by Doyle and Lorens (1982). The rainfall-runoff coefficient was determined by dividing the runoff volume (runoff depth) by the rainfall total (rainfall depth). Rainfall duration represents the time in minutes from the first recorded
0.01 inch of rainfall to the last 0.01 inch of rainfall for a storm. The storm-runoff duration represents the time in minutes that the storm-drain flow was about $0.01 \mathrm{ft}^{3} / \mathrm{s}$ (approximate flow-recording threshold) or greater. The number of hours since the previous storm represents the approximate time in hours between the last 0.01 inch of rainfall of the previous storm and the start of storm-drain flow (about 0.1 $\mathrm{ft}^{3} / \mathrm{s}$ ) for the following storm.

The rainfall-runoff coefficient should range between 0 and 1 ; however, some of the calculations for the multipledwelling residential and commercial catchments resulted in coefficients greater than 1. Coefficients greater than 1

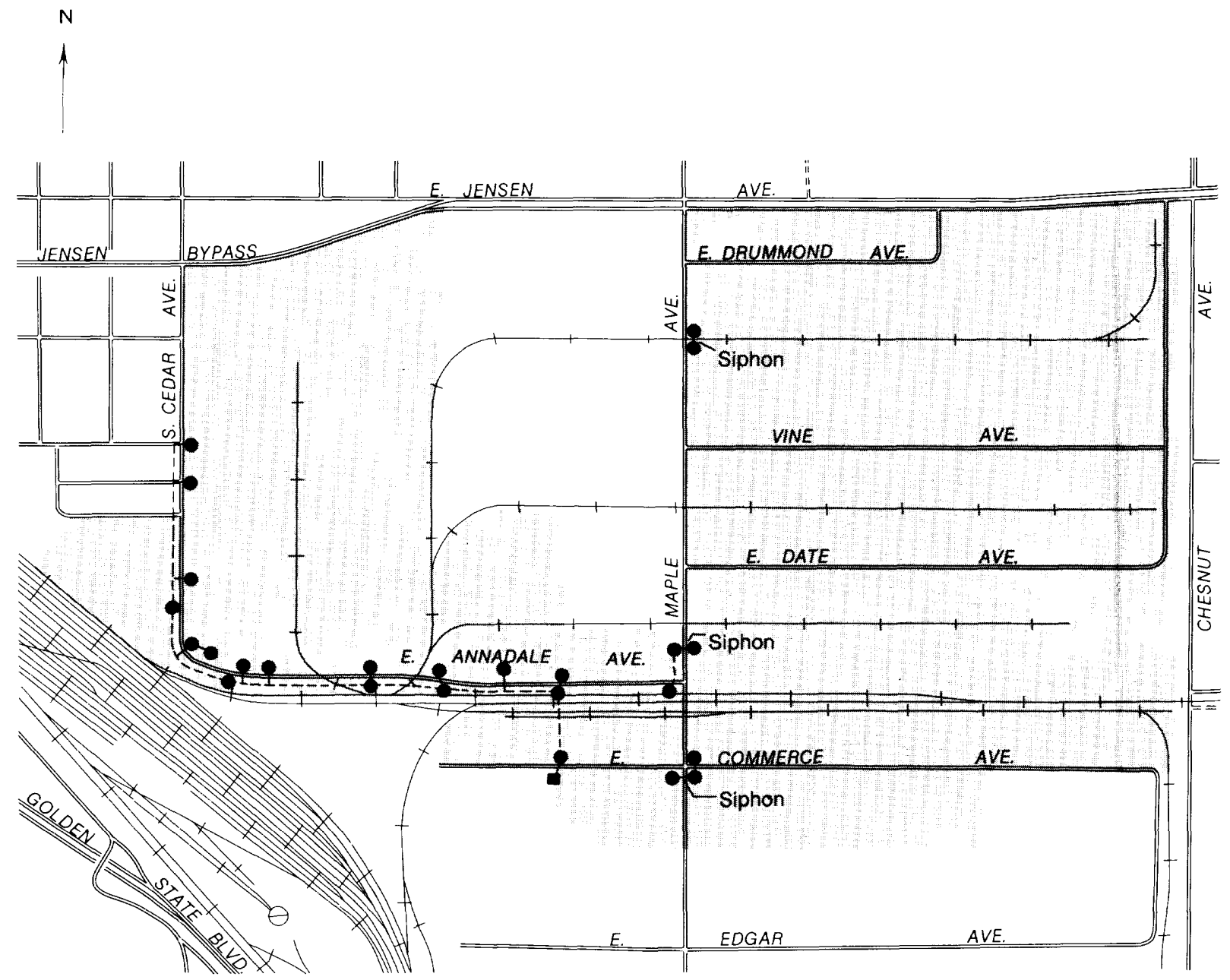

\section{A, Industrial catchment}

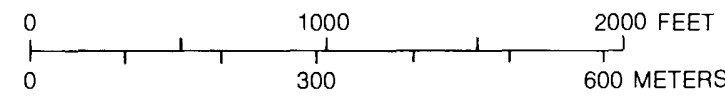

\section{EXPLANATION}

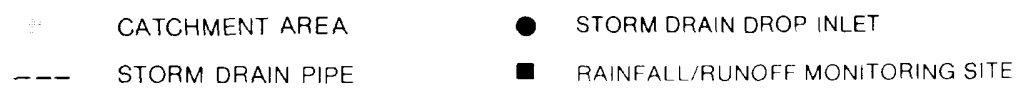

Figure 4. Monitored catchments. $A$, Industrial catchment. $B$, Single-dwelling residential catchment. $C$, Multiple-dwelling residential catchment. $D$, Commercial catchment. 


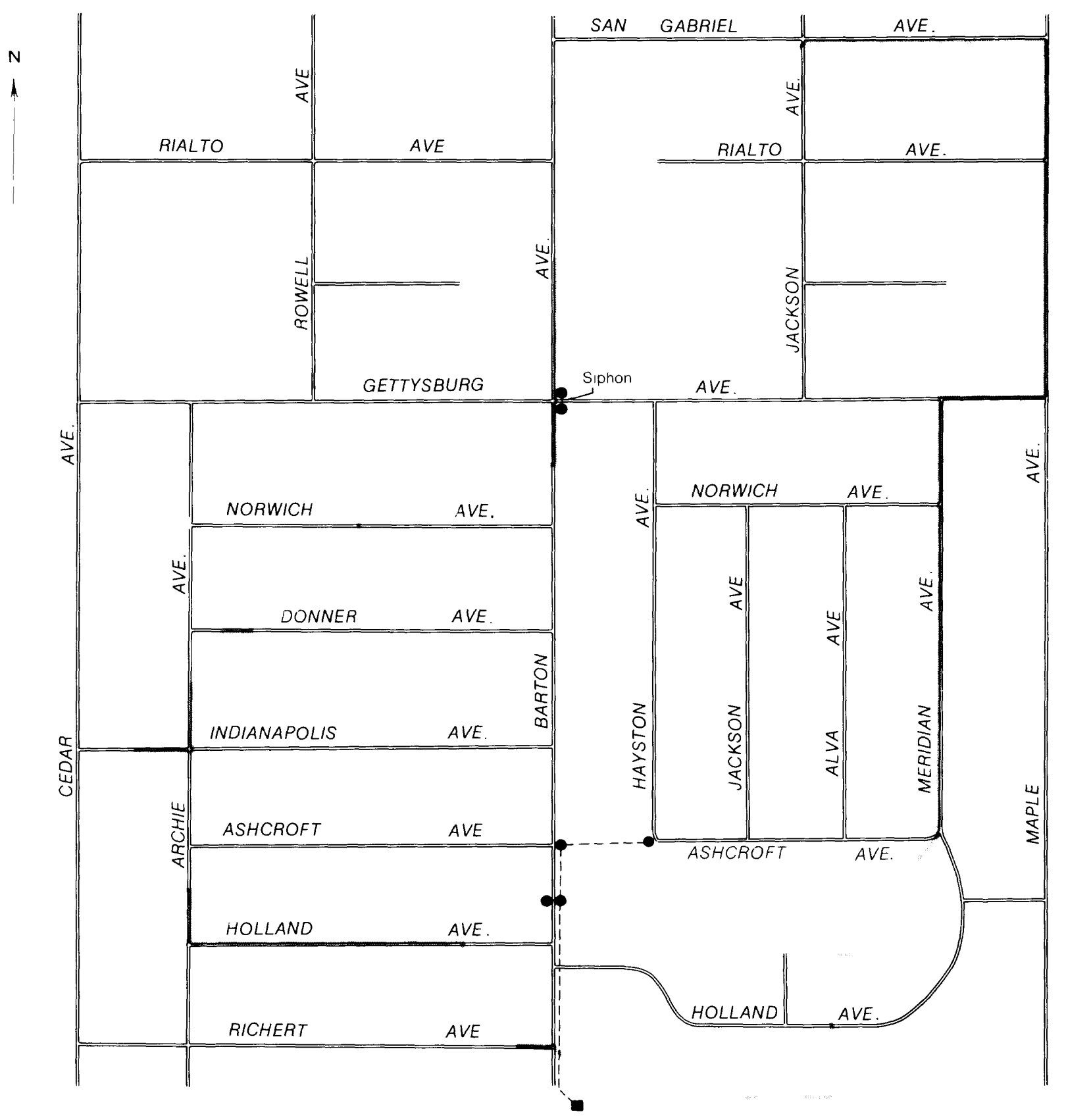

B, Single-dwelling residential catchment

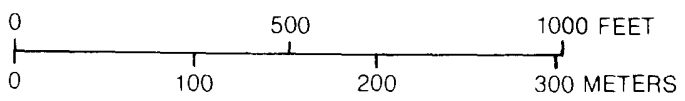

\section{EXPLANATION}

CATCHMENT BOUNDARY

- - $\quad$ STORM DRAIN PIPE
- Storm dRain dRop inLet

- RaINFALl/RUNOFF MONITORING Site

Figure 4. Continued. 
probably occur for the commercial catchment because of a combination of data collection inaccuracies and a 98.9percent impervious catchment surface (table 1). Because of the high percentage of impervious surface, nearly all rainfall that lands on the catchment should drain off. Therefore, data collection inaccuracies become critical in this near-continuity situation. For example, if the recorded rainfall, which is collected at one location in or near the catchment, is less than the actual average rainfall over the catchment, a coefficient greater than 1 will result. Other data collection inaccuracies that could contribute to a coefficient greater than 1 include errors in collection of the storm-drain stage record, determination of stage discharge relation (Oltmann and others, 1987), and determination of the catchment drainage area.

Coefficients greater than 1 also were obtained for two storms for the multiple-dwelling residential site (1.01 on
January 22 and 1.05 on February 28, 1983). Both storms were high rainfall intensity storms that caused the storm drain to flow full, therefore, the flow records were estimated for these periods (Oltmann and others, 1987). Another possible cause for the coefficients to be greater than 1 is that the highintensity rainfall caused runoff from an adjacent catchment to enter the monitored catchment.

Table 5 represents a statistical summary of the storm characteristics data shown in table 4 . Because of the unusually high rainfall total during the second rain season, the mean storm characteristics data shown in table 5 (except for the commercial catchment) probably are higher than the actual mean storm characteristics values. The effect of the high rainfall total on the mean rainfall-runoff coefficient is discussed in the section "Estimation of Land-Use Average Annual Constituent Unit Loads."

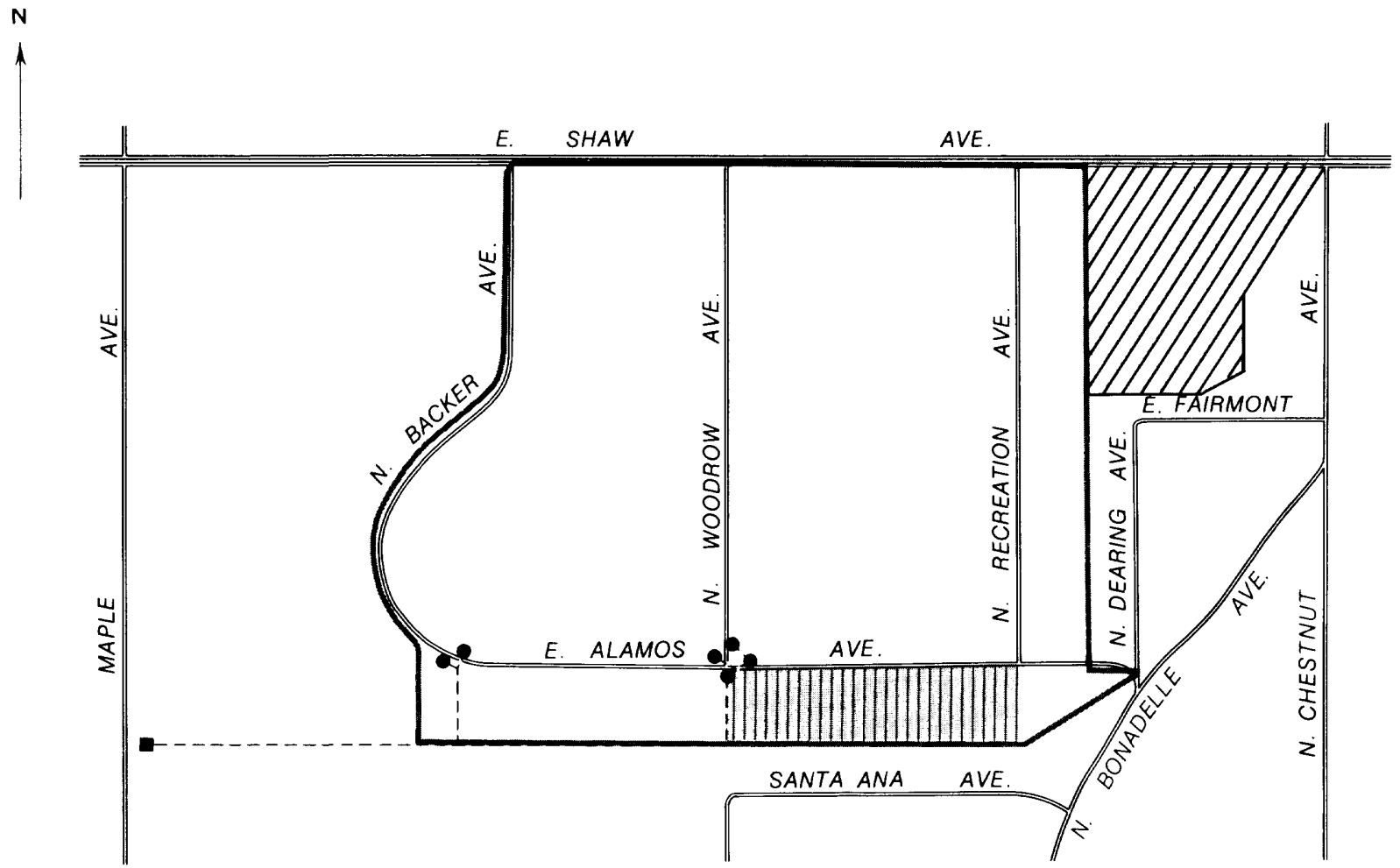

C, Multiple-dwelling residential catchment

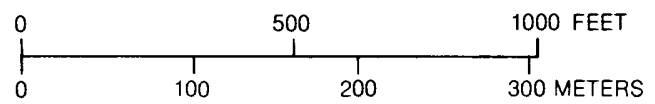

\section{EXPLANATION}
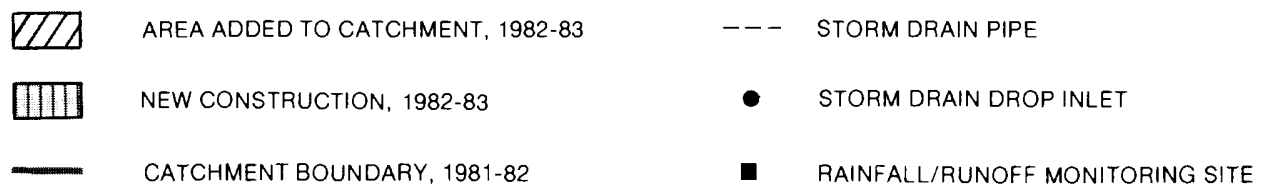

Figure 4. Continued. 


\section{Rainfall-Runoff Regression Analysis}

Multiple linear-regression analysis for each of the four catchments was done using the data in table 4 and REG pro- cedure of the computerized statistical analysis system, SAS (Helwig and Council, 1979). The dependent variable was designated as runoff and regressed against the independent variables rainfall total, maximum 20 -minute rainfall total

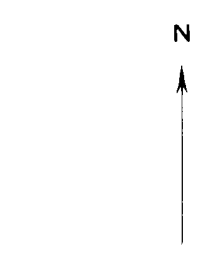

N

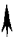

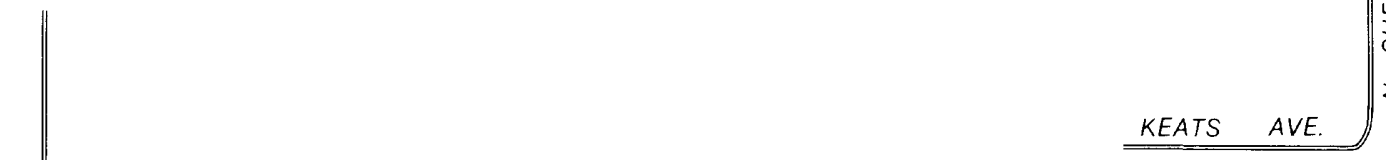

z

\section{SHAW}

AVE
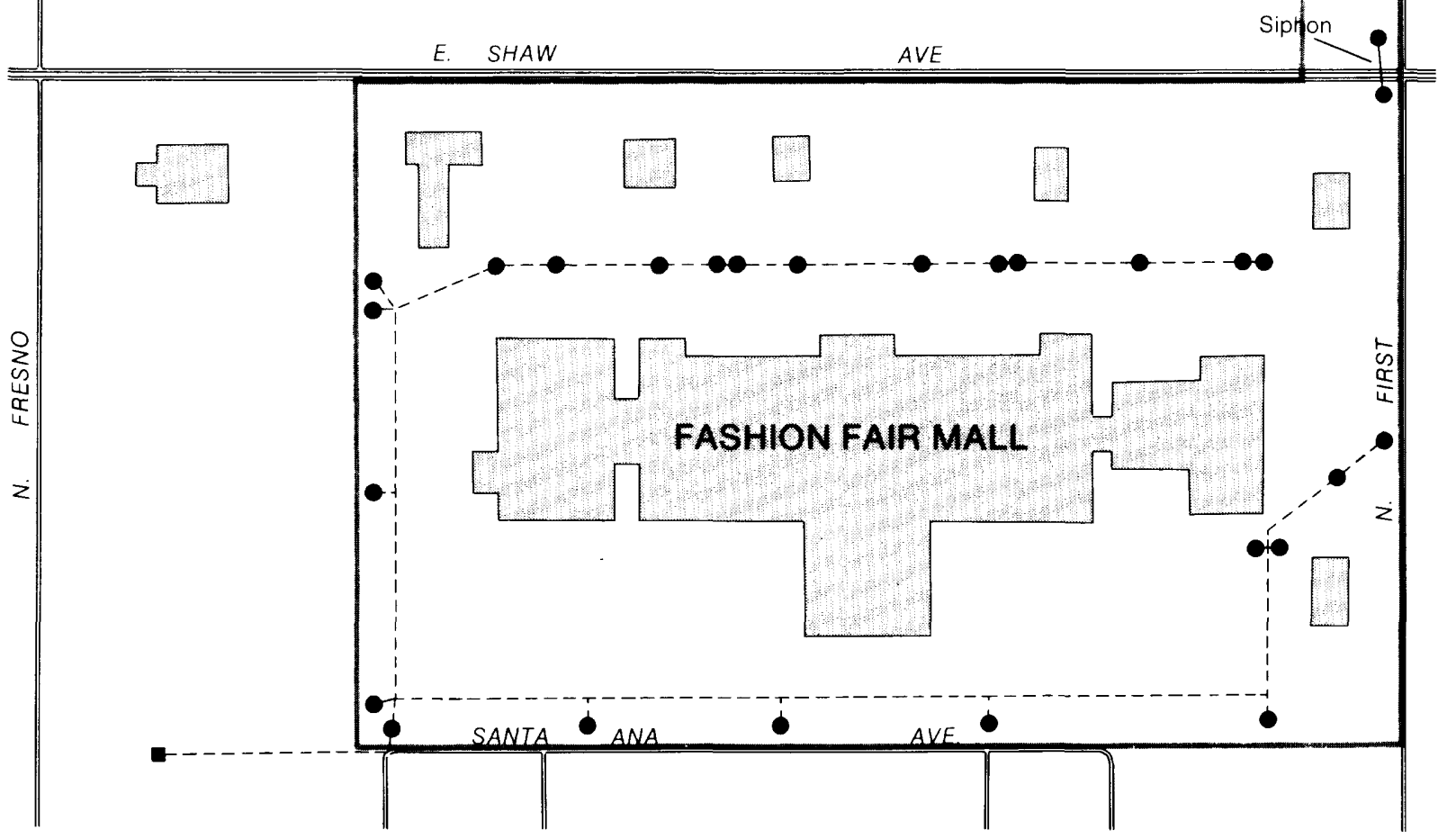

D, Commercial catchment

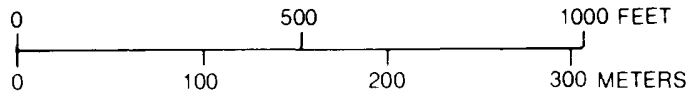

EXPLANATION

\section{- CATCHMENT BOUNDARY}

- - STORM DRAIN PIPE
- storm dRain dROP INLET

- rainfall/Runoff monitoring site

Figure 4. Continued. 
(MAX20), and number of hours since the previous storm (DRYHRS).

If DRYHRS is a significant independent variable, an appreciable part of the catchment surface has soil areas that need to reach saturation before runoff occurs from these areas, and (or) significant depression areas must be filled before runoff occurs. If MAX20 is a significant variable, the catchment soils have a high infiltration rate, and the rainfall rate must exceed the infiltration rate in order for runoff to occur from the pervious soil areas.

The regression results indicate that the significance of the three independent variables differed between catchments. Regression results for each of the four catchments are shown in figure 6, which includes the regression equation for estimating runoff volume, percent of variation of dependent variable explained by the independent variables adjusted for sample size $\left(R^{2}\right)$, root mean square error, and a comparison plot of predicted and measured runoff.

The analysis for the commercial catchment produced a simple linear regression equation as the best model, with rainfall total being the only independent variable that was significant at the 0.05 -significance level $(\alpha=0.05)$. This result is again the direct result of the 98.9-percent impervious catchment surface.

The analysis for the other three catchments resulted in multiple logarithmic-linear regression equations. The only significant independent variables for the equations for the single-dwelling residential and industrial catchments were rainfall total and DRYHRS. All three independent variables were significant for the multiple-dwelling residential catchment. These results are consistent with the catchment characteristics data shown in table 1. All three catchments have a large
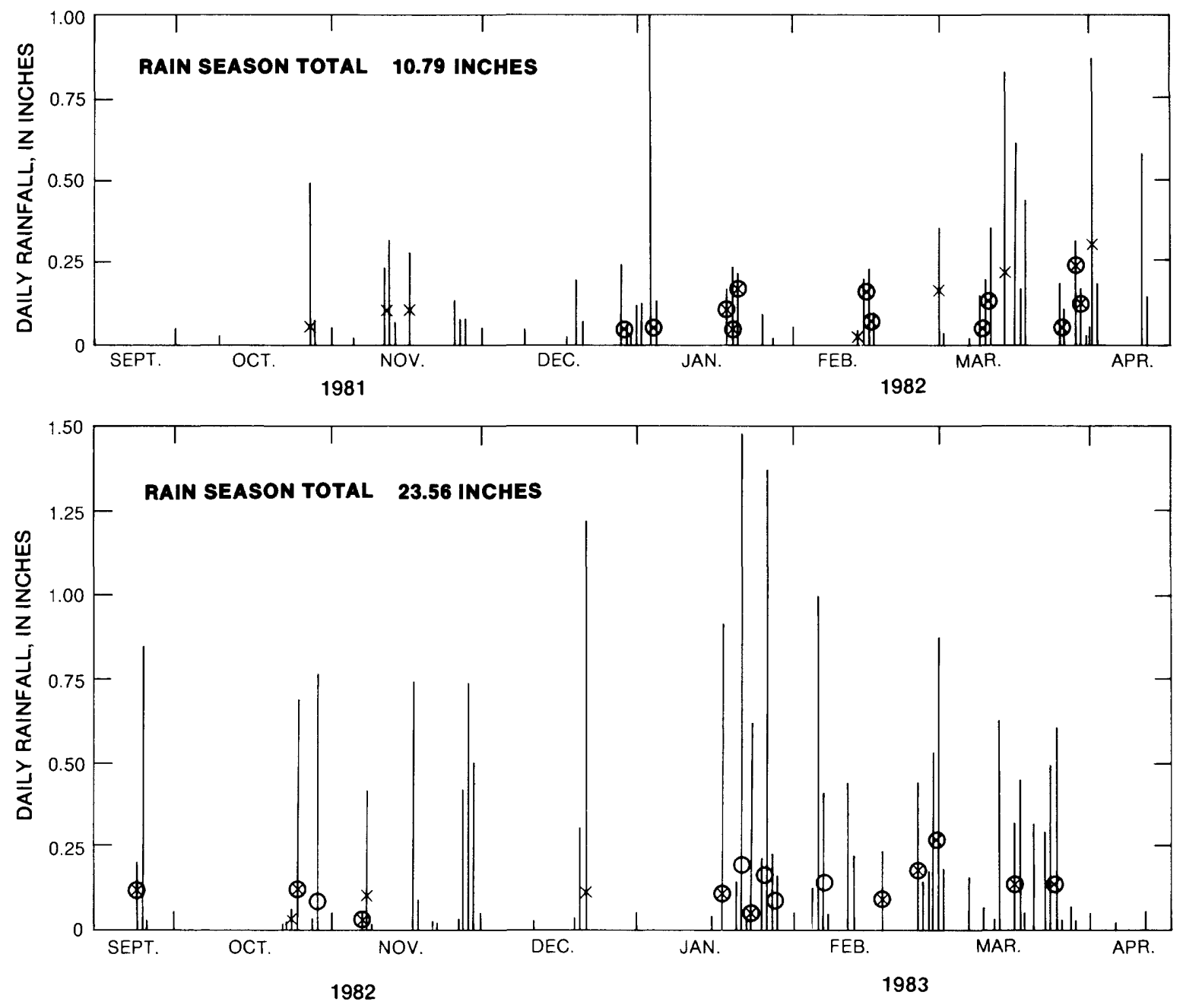

EXPLANATION

RAINFALL QUALITY DATA OTHER THAN SPECIFIC CONDUCTANCE AND pH

$\times \quad$ RUNOFF QUALITY DATA OTHER THAN SPECIFIC CONDUCTANCE AND $P H$

Figure 5. Daily rainfall and storms for which rainfall or runoff quality data were collected. (Daily rainfall totals measured at the Fresno Air Terminal by the National Weather Service.) 

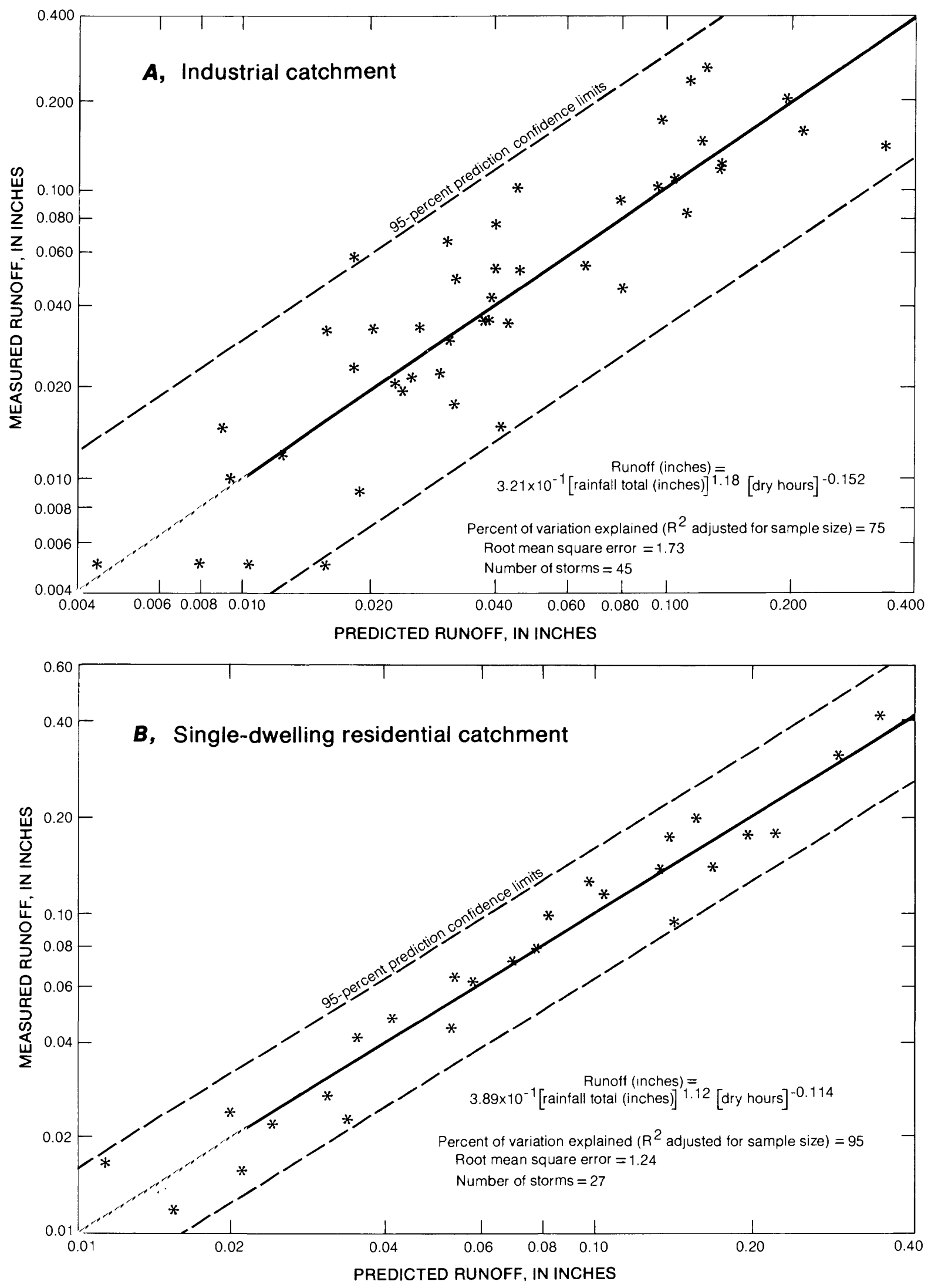

Figure 6. Results of rainfall-runoff regression analysis for each of four monitored catchments. $A$, Industrial catchment. $B$, Single-dwelling residential catchment. $C$, Multiple-dwelling residential catchment. $D$, Commercial catchment. 

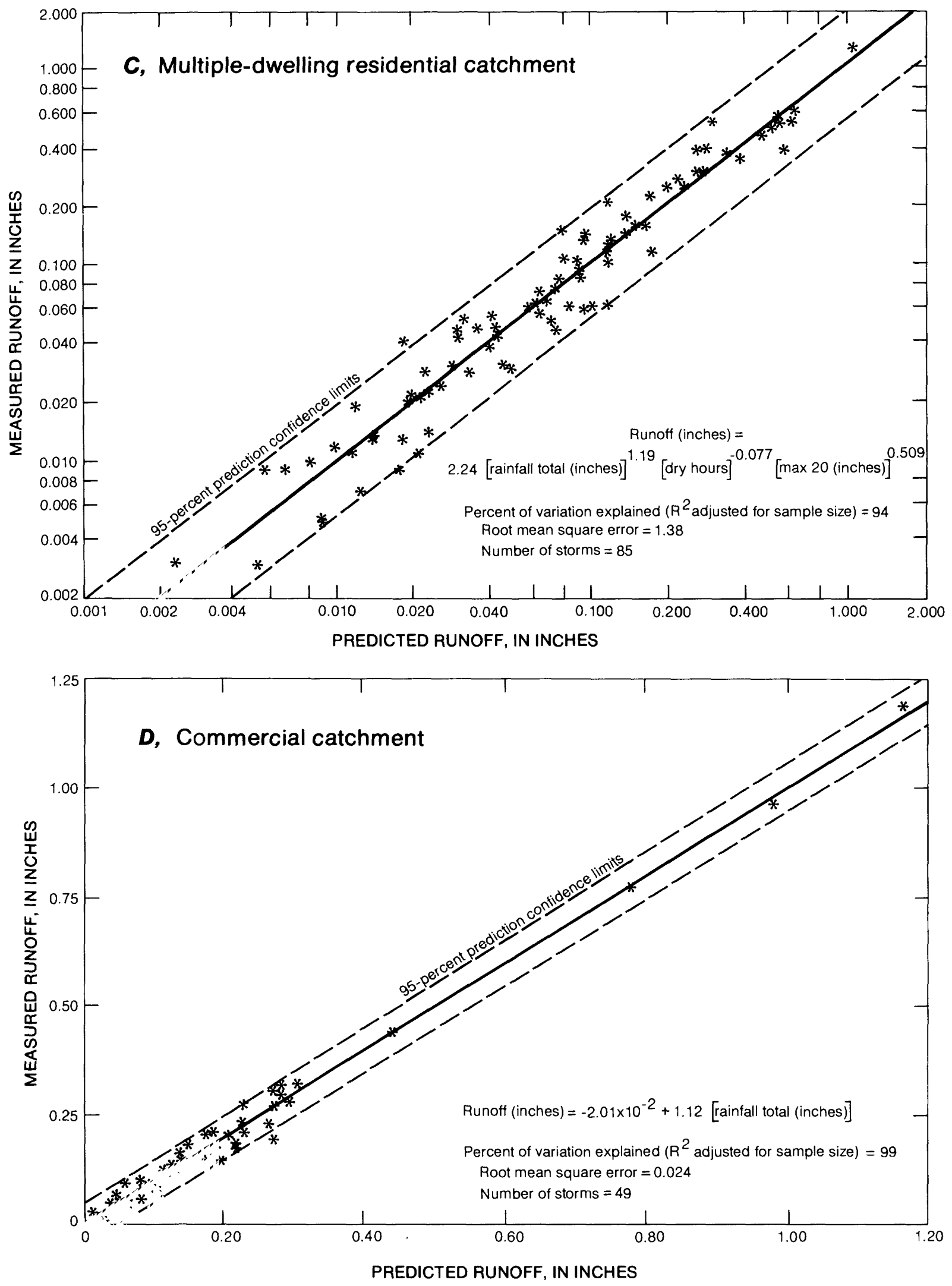

Figure 6. Continued. 
percentage of pervious surface (signified by DRYHRS as an independent variable), and the multiple-dwelling residential catchment consists of soil with a higher infiltration rate (soil group A) than the other two catchments (soil group B), which is signified by the independent variable MAX20.

The regression equation for the commercial catchment for rainfall totals greater than 0.17 inch calculates a runoff volume which exceeds the rainfall total. This anomaly is due to data collection inaccuracies as discussed earlier. Only data for the first rain season for the commercial catchment were used in the regression analysis because of the inaccuracies of the flow record in the second rain season caused by the construction activities adjacent to the catchment as discussed in Oltmann and others (1987).

The percent of variation explained for the industrial catchment ( 75 percent) is lower than the other three catchments ( 94 percent and higher) because the industrial catchment has a larger percentage of idle and vacant land (table 1) and has more depression storage compared to the other three catchments. Field observations during storms revealed a larger quantity of depression storage in the industrial catchment compared to the other three catchments, especially in the storm-drain system. Depression storage also was observed on some of the vacant industrial lands.

\section{Rainfall-Runoff Response}

The magnitude and response of runoff from a catchment are related to the amount of effective impervious area in the catchment. Effective impervious areas drain directly to water conveyance channels that route the runoff to the monitoring location. Noneffective impervious areas drain to pervious areas and therefore do not contribute to the runoff hydrograph unless infiltration demands have been met.

If all of the impervious areas in a catchment are effective impervious areas, the percentage of rainfall that drains off a catchment (rainfall-runoff coefficient multiplied by 100) will be about equal to the percentage of impervious area in the catchment. Comparison of the mean rainfall-runoff coefficients for each catchment (table 5) and the percentage of impervious area (table 1) indicates that a large part of the impervious area for the two residential and industrial catchments are not effective impervious areas. The impervious area for the commercial catchment is almost entirely an effective impervious area.

To graphically compare rainfall-runoff response for the four catchments, flow hydrographs and rainfall bar graphs (hyetographs) for a typical storm (November 17, 1981) are shown in figure 7 . The hydrographs show that the highly impervious commercial catchment responds faster to rainfall than the other catchments, which results in steeper rising and falling hydrograph limbs, and higher peak flows. The high percentage of effective impervious area for the commercial catchment also produces a much greater runoff volume even though the industrial and single-dwelling residential catchments have larger drainage areas.

\section{Rainfall Quality Samples}

Numerous storm-composite (bulk) rainfall samples were collected on a storm basis at the industrial and single-dwelling residential sites during the 1981-82 and 1982-83 rain seasons. In addition, a third rainfall quality collection site was established at the project's laboratory (fig. 3) during the 1982-83 rain season. This third collection site was initiated because there was concern that the rainfall quality at the single-dwelling residential site might be affected by its proximity to the Fresno Airport (fig. 3), and that the rainfall quality at the industrial site might be affected by its surrounding environment. If the two concerns were true, neither site's data would be suitable for use in future studies to estimate rainfall quality for the remaining majority of the Fresno urbanized area. This does not imply that the laboratory rainfall data would be truly representative of the remaining urbanized area, but these data should not be affected by the above-mentioned interferences. The laboratory site was a rainfall quality site only; total rainfall data were not collected.

Rainfall quality usually will vary throughout a storm. The measurements made of a storm-composite sample could be considerably different from measurements of discrete samples of rainfall collected during that storm. This may be particularly true for $\mathrm{pH}$. However, the objective was to obtain results that were representative of the entire storm. Therefore, the results represent rainfall event mean concentrations (EMC).

Statistical summaries of all the rainfall quality data including the number of samples and the mean, median, standard error of mean, standard deviation, maximum, and minimum values for analyzed constituents are presented for each of the three sites in tables 6 through 8 .

\section{Comparison of Rainfall Quality}

Statistical testing was used to determine if rainfall quality (constituent concentrations) differed between the two rain seasons and among sampling sites. In order to determine which statistical comparison test would be used, the UNIVARIATE procedure of SAS (Helwig and Council, 1979) was used to evaluate the data distribution of the constituent concentrations. Depending on the number of samples, the UNIVARIATE procedure uses the Shapiro Wilk W-statistic $(N \leqslant 50)$ or a modified version of the Kolmogorov-Smirnov D-statistic (N>50) to test whether or not the data are normally distributed. If the data were not normally distributed, a nonparametric statistical procedure, the Kruskal-Wallis (chi-square approximation) test was used for testing. If the data were normally distributed, a parametric statistical procedure, ANOVA (analysis of variance) was used. Both tests are included in the NPAR1WAY procedure of SAS (Helwig and Council, 1979).

Results of the statistical comparison testing between rain seasons showed no significant difference $(\alpha=0.05)$ for any of the constituents measured at the single-dwelling residential site. At the industrial site, only dissolved phosphorus and dissolved organic carbon were significantly different between 
the first and second rain seasons. After this initial testing between years, all of the data from both years were combined into one data set for each site, except for the two constituents that differed between years at the industrial site. The results of testing between sites are shown in table 9. Most of the differences occurred between the industrial and singledwelling residential sites. Schematic plots for four of the constituents that did show significant differences- $\mathrm{pH}$, dissolved nitrogen ammonia, dissolved ammonia plus organic nitrogen, and phenols-are shown in figure 8.

The results shown in table 9 indicate that rainfall quality at the three different sites generally is comparable. However, microclimatic variations that occur in the urban area and localized air pollutants may affect rainfall quality in some areas. Of the five constituents that differed significantly between the industrial and single-dwelling residential sites, three $-\mathrm{pH}$, dissolved nitrogen ammonia, and dissolved ammonia plus organic nitrogen-could conceivably result from industrial plant emissions being discharged in and near the industrial catchment. There is not enough evidence at this time to confirm this conclusion.

The overall quality of the rainfall probably is affected more by regional inputs such as those from the agricultural lands surrounding Fresno than by localized effects. This conclusion is strengthened by some results of pesticides analysis, which will be discussed later.

\section{Computation of Rainfall Constituent Loads}

Storm rainfall and runoff constituent loads were not computed for all of the monitored quality constituents listed in table 2. Rainfall loads were computed for the 15 constituents listed below (runoff loads also were computed for these
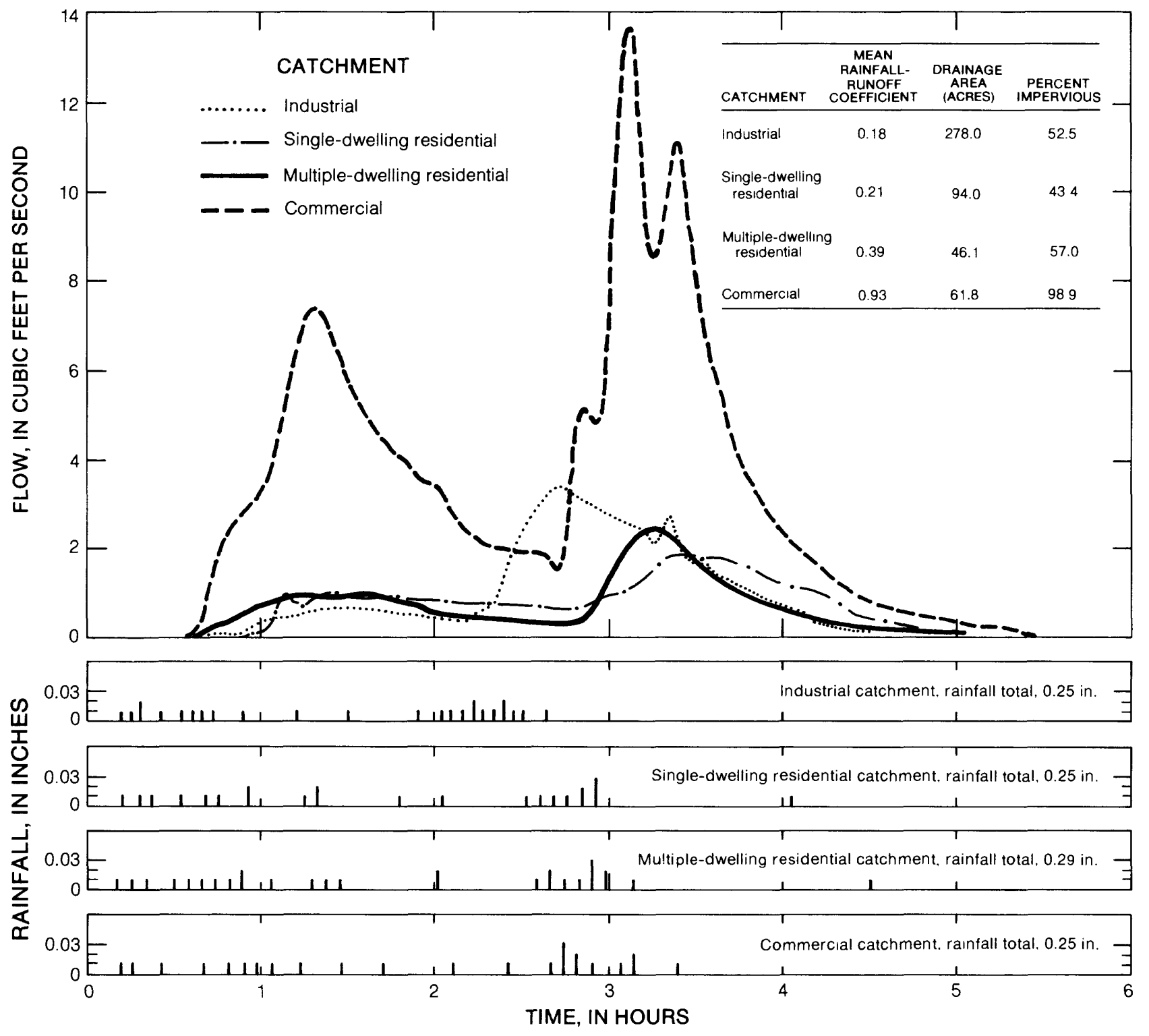

Figure 7. Flow hydrographs and hyetographs for each of four monitored catchments for a typical storm (November 17, 1981). 

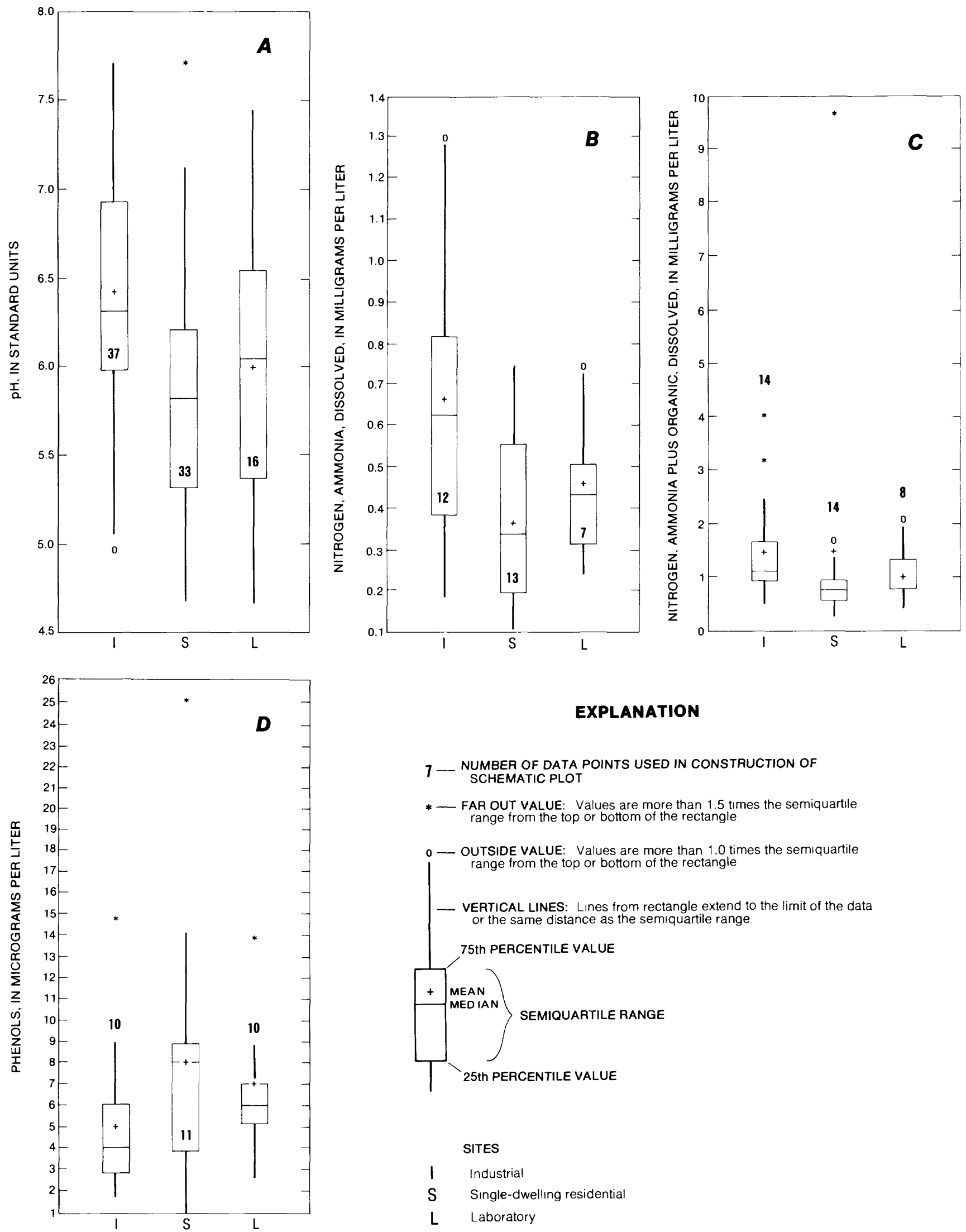

\section{EXPLANATION}

$$
\begin{aligned}
& 7 \text { - NUMBER OF DATA POINTS USED IN CONSTRUCTION OF } \\
& \text { SCHEMATIC PLOT } \\
& \text { * FAR OUT VALUE: Values are more than } 1.5 \text { times the semiquartile } \\
& \text { range from the top or bottom of the rectangle }
\end{aligned}
$$

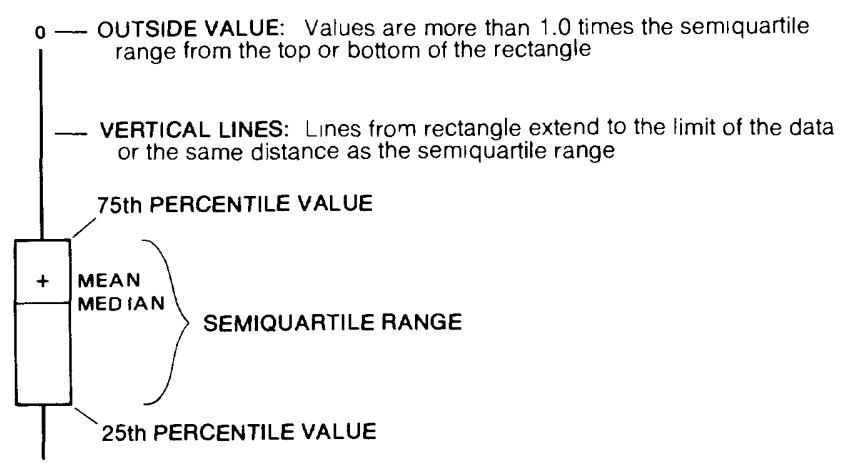

SITES

I Industrial

S Single-dwelling residential

L Laboratory

Figure 8. Four rainfall constituents that were determined to be significantly different. $A, \mathrm{pH} . B, \mathrm{Dissolved}$ nitrogen ammonia. $C$, Dissolved nitrogen (ammonia plus organic). D, Phenols. 
15 constituents in addition to 3 other constituents; refer to

"Computation of Runoff Constituent Loads" section): nitrogen, nitrite plus nitrate, dissolved nitrogen, ammonia plus organic, dissolved phosphorus, dissolved oxygen demand, chemical carbon, organic, dissolved aluminum, total recoverable arsenic, total chromium, total recoverable copper, total recoverable iron, total recoverable lead, total recoveraable manganese, total recoverable mercury, total recoverable nickel, total recoverable zinc, total recoverable

Rainfall constituent loads were computed using the following relation:

where

$$
L=0.2266(R \times D A \times C O N C),
$$

$L$ is rainfall load, in pounds;

$R$ is rainfall total, in inches;

$D A$ is catchment drainage area, in acres;

CONC is constituent concentration, in milligrams per liter; and

0.2266 is units conversion factor.

The resultant load is the quantity of a constituent, in pounds, that fell on the catchment for a given storm. The constituent concentration is the laboratory analyses concentration of the bulk rainfall sample collected for that storm (event mean concentration).

All the calculated storm rainfall constituent loads are given in tables 10 and 11. Loads were not computed for the laboratory site because rainfall quantity data were not available. Rainfall unit loads (for example, pounds per acre) were not computed or shown in the table because of the resultant very small numbers, and unit loads using square miles were possibly too large an extrapolation of the point data. Rainfall loads are compared to runoff loads in the "Comparison of Rainfall and Runoff Quality Data" section.

\section{Runoff Quality Samples}

Numerous discrete runoff samples were collected at the four monitoring sites during the two rain seasons of the study. Statistical summaries of these data including number of samples, mean, median, standard error of mean, standard deviation, maximum, and minimum are presented for each of the four catchments in tables 12 through 15 .

\section{Comparison of Catchment Runoff Quality Using Discrete Sample Data}

Comparison of land-use runoff quality was done by applying statistical tests to the discrete runoff constituent con- centration data. In order to compare catchment runoff quality, only sample results for common storms should be compared. However, because of the external electromagnetic field interference at the single-dwelling residential site during the first rain season and the construction activities adjacent to the commercial catchment during the second rain season, only a few storms have usable sample data for all four catchments (Oltmann and others, 1987). Therefore, in order to provide a larger data base for statistical comparison purposes, two data sets were formed each using storms common to only three catchments. The first data set included five storms common to the industrial, multiple-dwelling residential, and commercial catchments (Nov. 17, 1981; Jan. 4, 1982; Mar. 9-10, 1982; Mar. 10-11, 1982; Mar. 25-26, 1982). The second data set included eight storms common to the industrial, single-dwelling residential, and multiple-dwelling residential catchments (Nov. 12, 1981; Nov. 17, 1981; Mar. 9-10, 1982; Mar. 10-11, 1982; Mar. 25-26, 1982; Sept. 24, 1982; Oct. 25, 1982; Jan. 18, 1983). Statistical comparison testing was applied to each of these data sets with the results used to implicitly compare the single-dwelling residential and commercial catchments. Therefore, if there was no statistical difference between the data properties and values for a particular constituent for the three catchments in data set 1 , and no statistical difference for the same constituent for the three catchments in data set 2 , then the assumption could be made that there was no statistical difference of the data properties and values for that particular constituent between the singledwelling residential and commercial catchments.

The same statistical procedures described previously for rainfall quality were used for these analyses.

The runoff quality constituents that were determined to have no statistical difference $(\alpha=0.05)$ in concentration values for the catchments are shown in table 16 . Two significant conclusions can be drawn from the data in table 16: (1) The two residential catchments are quite similar with respect to quality of runoff (50 of the 57 constituents are similar), and (2) the industrial catchment runoff is quite different from the other three catchments (10 constituents are similar with at least one of the other catchments). The schematic plots for selected constituents shown in figure 9 present a visual comparison between catchments of the runoff quality constituent data.

Typical plots of nutrient data are shown in figure $9 A$, $B$; both show the conclusions stated above. Although some nutrient data for the commercial catchment are not statistically similar to any of the other three catchments, the plots do show that nutrient data for the commercial catchment are more representative of the two residential catchments than of the industrial catchment.

Typical plots of metal data are shown in figure $9 C-E$. The data for total recoverable copper and total recoverable zinc (plots not shown in fig. 9) are similar to total arsenic (fig. 9C); each shows markedly higher concentrations for the industrial catchment. The information shown in figure 
$9 D$, total recoverable lead, is unique in that it shows the industrial catchment concentrations to be lower than the other three catchments. The data for plots of total recoverable
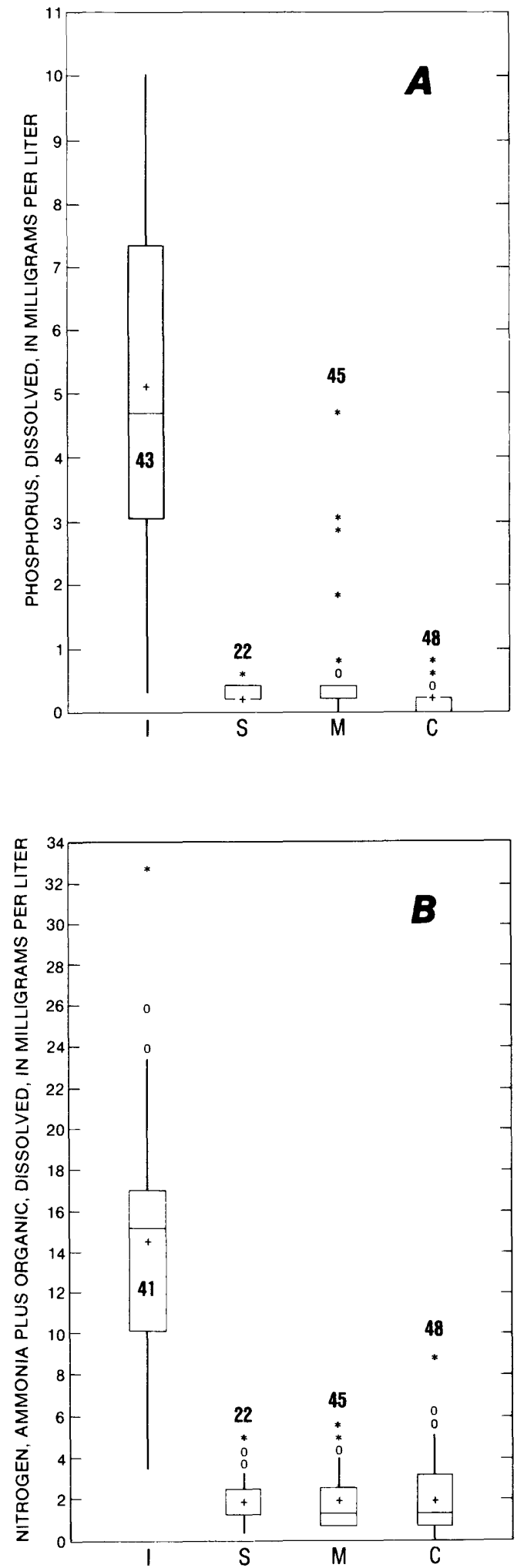

aluminum, manganese, and nickel (not shown in fig. 9) show the same relation to total recoverable iron (fig. $9 E$ ) of high concentrations at the industrial and multiple-dwelling residen-
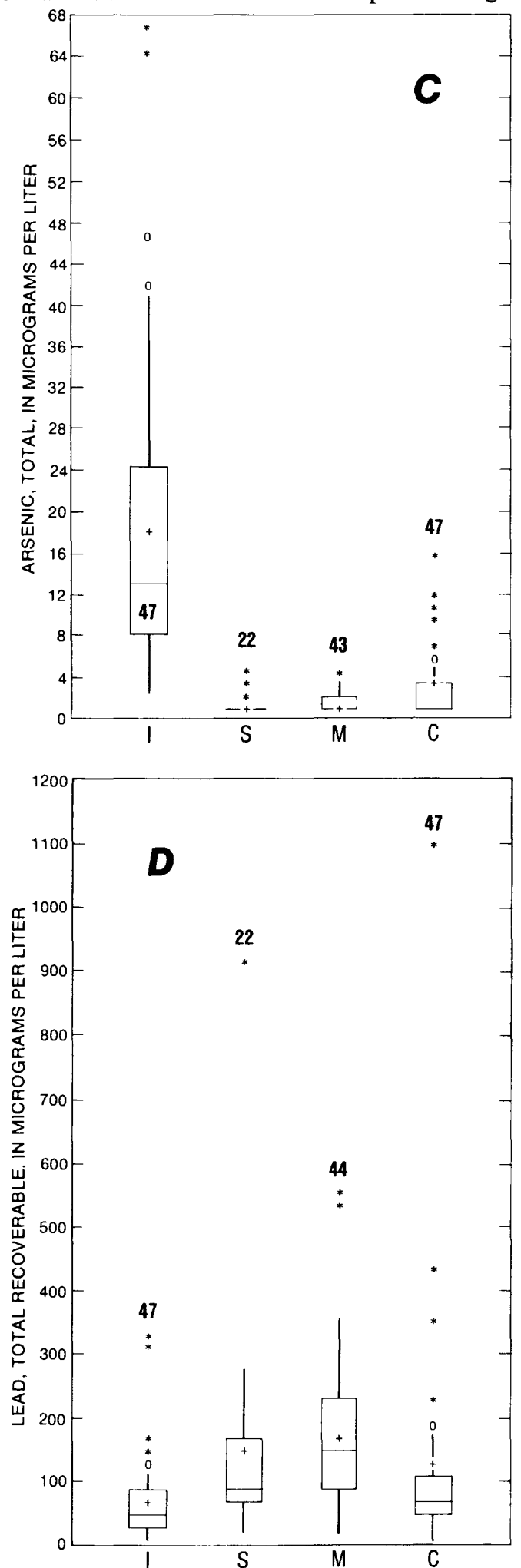

Figure 9. Comparison between catchments for selected constituents using runoff quality data. $A$, Dissolved phosphorous. $B$, Dissolved nitrogen (ammonia plus organic). $C$, Total arsenic. $D$, Total recoverable lead. $E$, Total recoverable iron. $F$, Suspended sediment. $G$, Chemical oxygen demand. $H$, Biochemical oxygen demand. 
tial catchments and low concentrations at the single-dwelling residential and commercial catchments. Comparing these plots with the suspended sediment (fig. $9 F$ ) indicates the same
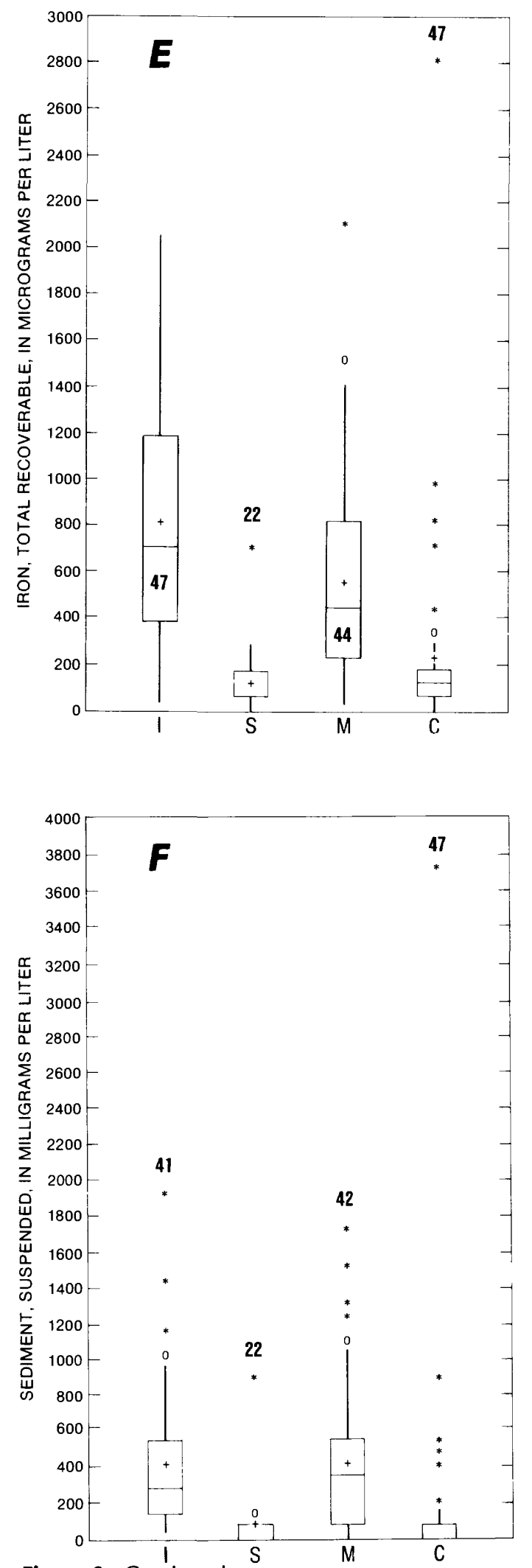

relation. Both the industrial and multiple-dwelling residential catchments have undeveloped land where soil erosion could take place, thus causing the higher suspended-sediment
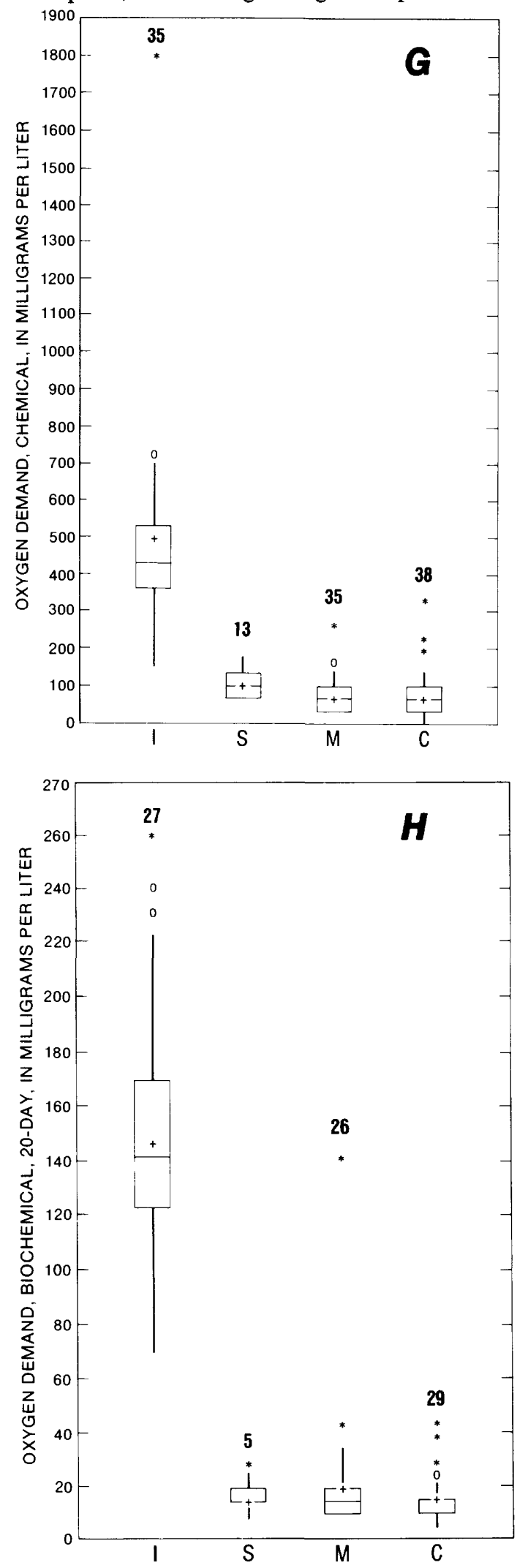

Figure 9. Continued. 
concentrations and metal concentrations because these metals are abundant in soils. Therefore, these metal data may not be typical of runoff from a fully developed multiple-dwelling residential or industrial catchment. Data shown for chemical oxygen demand (fig. 9G) and 20-day biochemical oxygen demand (fig. $9 \mathrm{H}$ ) are typical of most constituent concentration plots, with the industrial catchment concentrations far exceeding the concentrations at the other three catchments.

The cations (calcium, alkalinity, magnesium, sodium, and potassium) and the anions (chloride, sulfate, bicarbonate, nitrate, and ammonia) are shown for each catchment in figure 10. These pie diagrams show average ion concentrations in milliequivalents per liter (meq/L) for all analyses for each catchment. In an ideal situation, the total cations in milliequivalents per liter will equal the total anions in the same units within 1 or 2 percent. In instances where the anion plus cation total is less than about $5.00 \mathrm{meq} / \mathrm{L}$, larger percentage errors sometimes occur (Hem, 1970). Urban runoff samples are particularly troublesome because chemical transformations are occurring rapidly as the dilute rainfall rapidly mixes with solids on the ground. This explains the slight cationanion imbalances seen in the pie diagrams. In spite of the imbalances, comparisons can be made of the general water types discharging from each catchment.

As with other inorganic and organic constituents, a difference between the industrial catchment and the other three catchments is noticeable. The predominance of sodium and

\section{EXPLANATION}

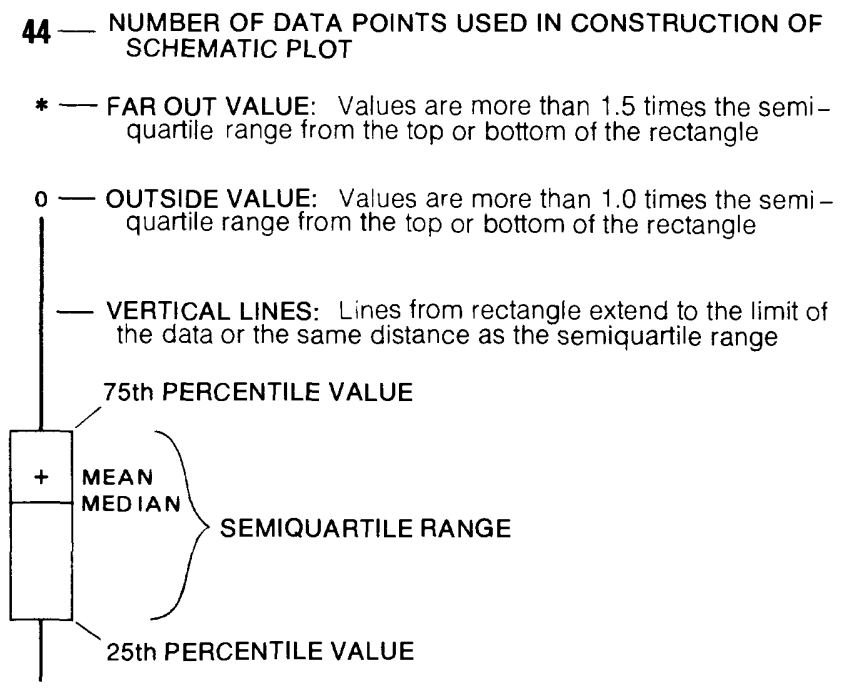

CATCHMENTS

I Industrial

S Single-dwelling residential

M Multiple-dwelling residential

C Commercial

Figure 9. Continued. chloride from the industrial catchment contrasts sharply with the more balanced ionic composition of runoff from the single-dwelling residential, multiple-dwelling residential, and commercial catchments. The large proportion of sodium chloride in solution from the industrial catchment is indicative of the unusual conditions that exist in an industrial catchment. For the other three catchments, the cation calcium and the anion bicarbonate account for about 50 percent of the total composition, and the ionic composition for each catchment is similar.

Comparison testing of the fecal-coliform bacteria data was not done because of the small unbalanced data set, and the uncertainty of the data. The 6-hour sampling-toprocessing time constraint for fecal-coliform bacteria caused numerous logistic problems that limited the number of samples that could be analyzed for fecal-coliform bacteria. When samples were collected and analyzed within the 6-hour time limit, a large percentage resulted in culture plates with colonies too numerous to count. The variability of urban runoff made it difficult to select a range of sample volumes that would result in an ideal colony count.

During the first rain season only, 26 dibromochloropropane (DBCP) samples were collected from the four catchments. The analytical results for 21 of the 26 samples were less than the detection limit of 0.003 microgram per liter $(\mu \mathrm{g} / \mathrm{L})$. Each catchment had at least one sample concentration greater than the detection limit, with the exception of the commercial catchment that had two results greater than the detection limit, including the $0.01-\mu \mathrm{g} / \mathrm{L}$ maximum.

During the second rain season only, 22 volatile organic samples were collected from the four catchments. The samples were analyzed for benzene, chlorobenzene, and ethylbenzene. The analytical results did not produce any concentrations greater than the detection limit of $1.0 \mu \mathrm{g} / \mathrm{L}$.

\section{Variation of Constituent Concentrations Throughout a Storm}

Most constituent concentrations were highest in the initial runoff of a storm. Constituents accumulated on the catchment since the previous storm and located near the monitoring site are washed off by the initial storm runoff. Therefore, the initial runoff results in high constituent concentrations because of the low runoff volumes that transport the collected constituents. Constituents that have collected on the catchment at greater distances from the monitoring site also are first transported by small quantities of initial runoff, but usually are well diluted by the time they reach the monitoring site resulting in lower constituent concentrations. Therefore, high constituent concentrations associated with initial washoff are a localized phenomenon.

Constituent concentrations vary during a runoff event depending upon the type of constituent. Nutrient concentrations generally are highest at the beginning of storm runoff and then steadily decrease throughout the runoff event irrespective to variation in flow (fig. 11). Metal concentrations generally are higher at the beginning of runoff, but vary 
thereafter depending on velocity. This variation probably is because metals are associated with sediment particles (Gibbs, 1977), and larger sediment particles are transported by higher velocities. Therefore, the highest metal and sediment concentrations usually are found on the rising limb of a hydrograph (fig. 11). Chemical oxygen demand, 20-day

\section{A, Industrial catchment}

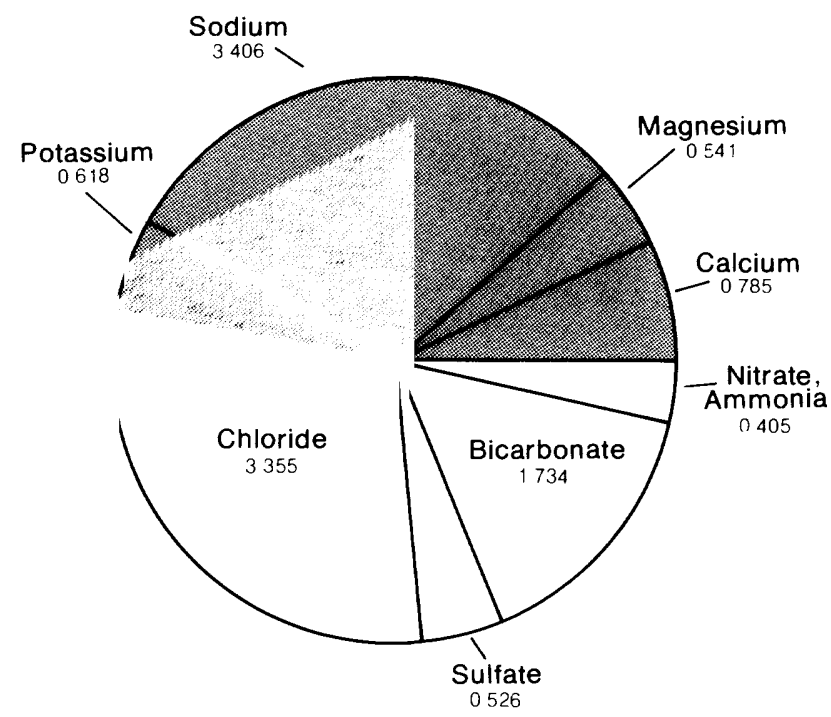

\section{B, Single-dwelling residential catchment}

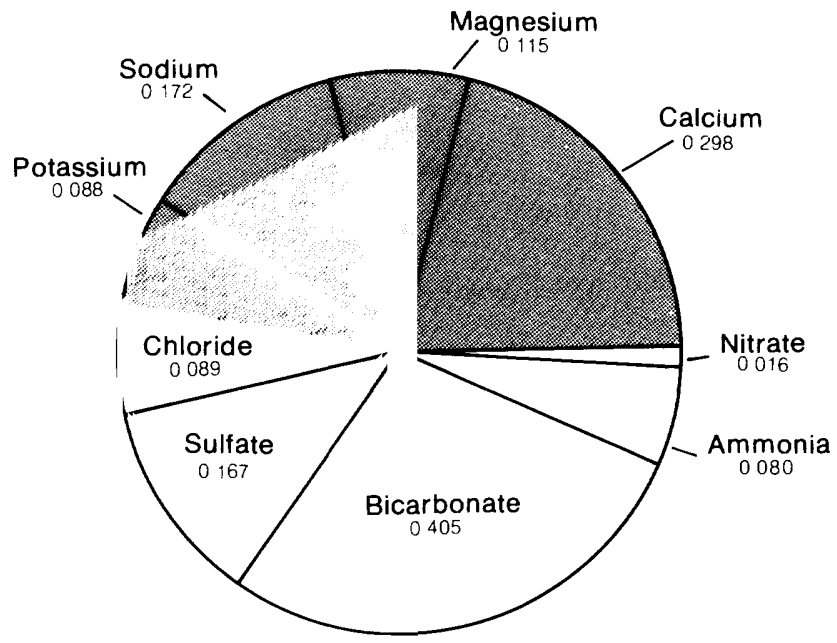

biochemical oxygen demand, and specific conductance (related to ion concentrations) all vary throughout a hydrograph similar to nutrient constituents (fig. 11).

The plots shown in figure 11 are typical of all the monitored catchments except for the industrial catchment, which did not demonstrate constituent concentration patterns

\section{C, Multiple-dwelling residential catchment}

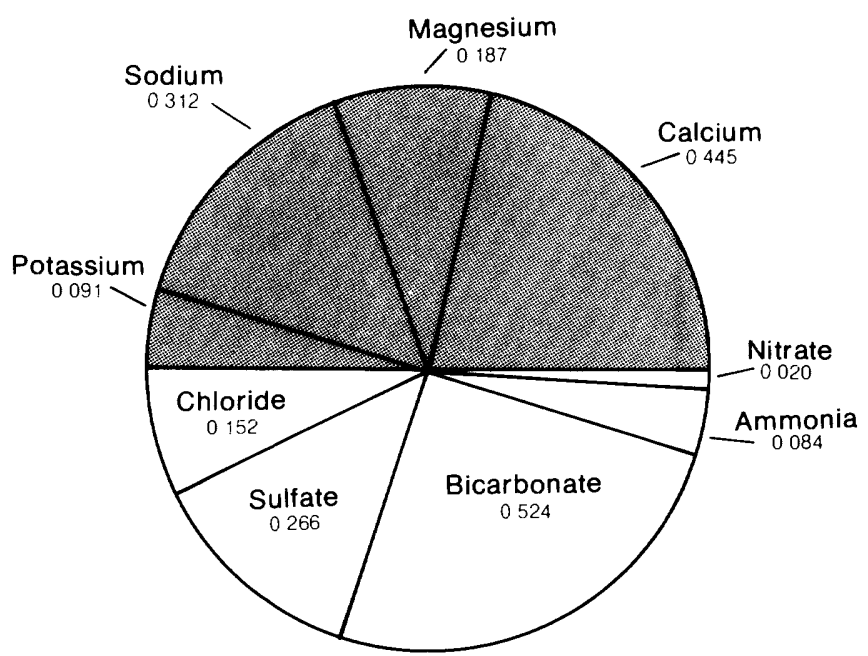

D, Commercial catchment

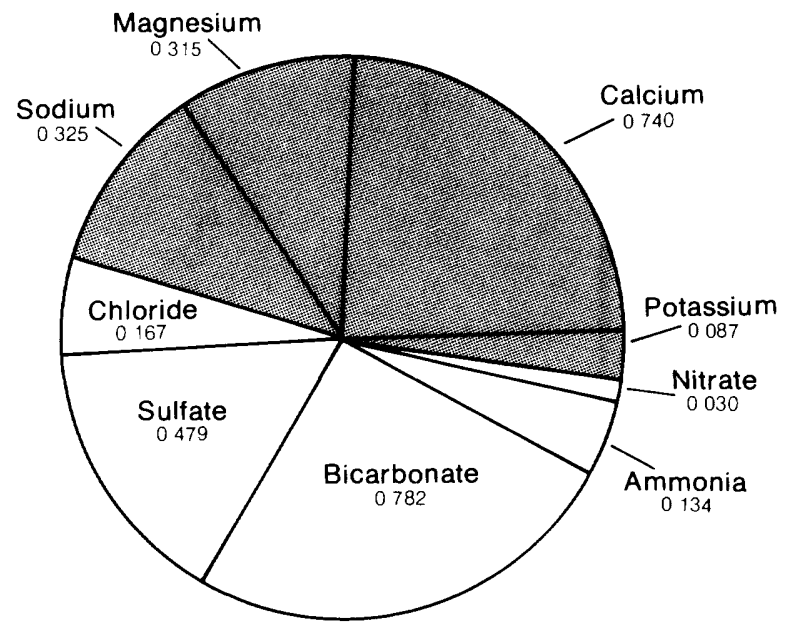

AVERAGE OF ALL SAMPLES, IN MILLIEQUIVALENTS PER LITER

CATIONS

ANIONS

Figure 10. Average concentrations of dissolved major ions for runoff for each of four monitored catchments. 
throughout a storm. A typical constituent concentration plot for the industrial catchment is shown in figure 12 . The plot shows the highest concentrations of phosphorus and chemical oxygen demand occurred unexpectedly in the middle of the hydrograph and were not associated with a peak flow. Numerous high specific-conductance spikes were recorded for the industrial catchment during the study period, the largest of which occurred October 25, 1982, when the specific conductance rose from 666 to 9,960 microsiemens per centimeter $(\mu \mathrm{S} / \mathrm{cm})$ in 8 minutes, and then receded to $1,025 \mu \mathrm{S} / \mathrm{cm} 24$ minutes later. These random concentration spikes were common for the industrial catchment and
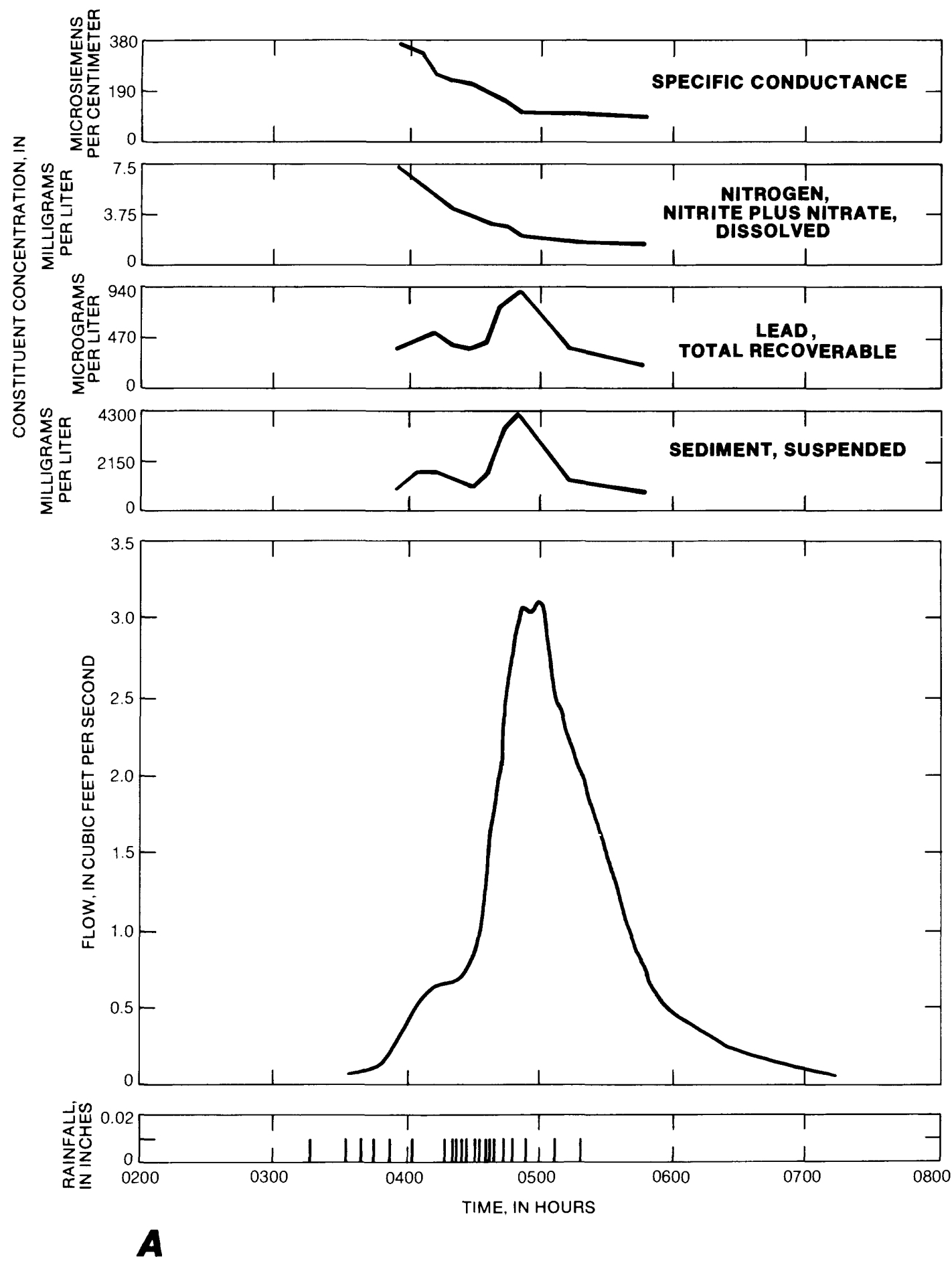

Figure 11. Typical constituent concentration plots and flow hydrographs. A, Multiple-dwelling residential catchment, September 24, 1982. B, Multiple-dwelling residential catchment, January 18-19, 1983. C, Commercial catchment, November 17, 1981. 

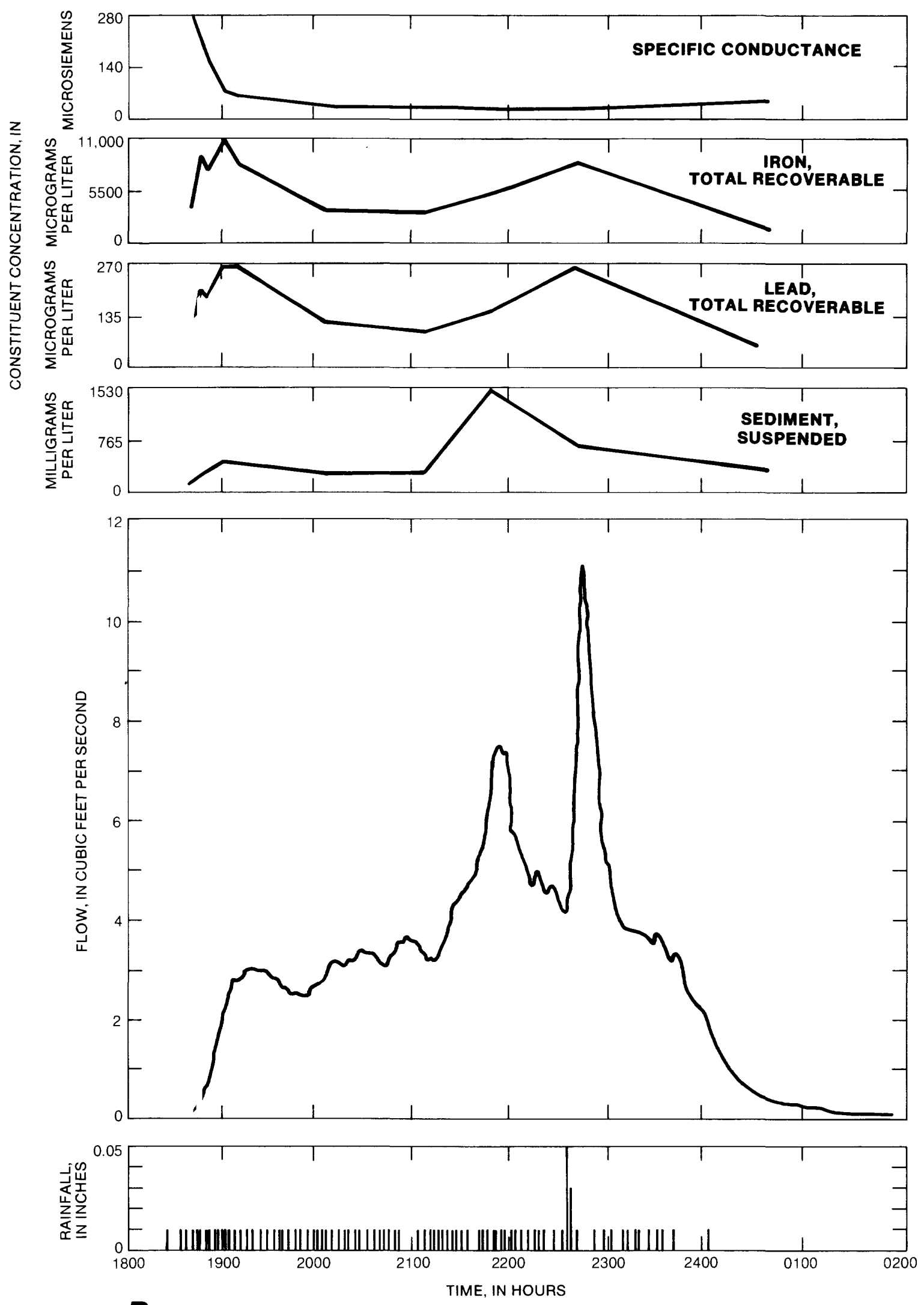

B

Figure 11. Continued. 
probably were due to runoff from various point sources in the catchment. The arrival time was therefore dependent on the travel time between the point source and the monitoring point.

On January 11,1983 , an attempt was made to verify that the high constituent concentrations collected at the beginning of a storm are associated with catchment washoff and are not a result of flushing the storm-drain monitoring pipe of residue deposited since the last storm. The test consisted of simulating storm runoff at the multiple-dwelling residential site by discharging fire-hydrant water into the monitoring storm-drain pipe at the point where storm runoff enters the pipe. Samples were collected using the automatic sampling equipment in the same manner as if there was actual
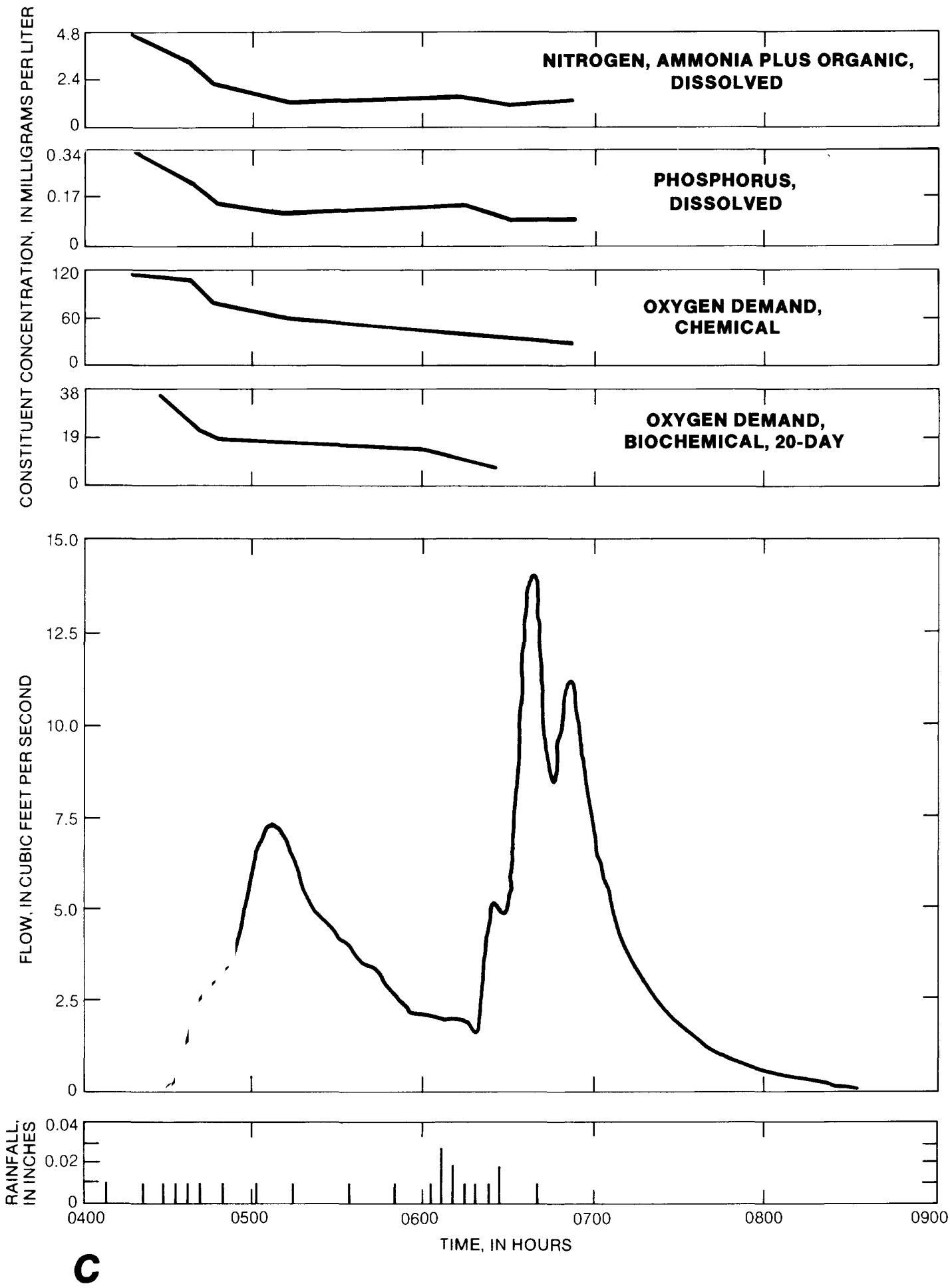

Figure 11. Continued. 

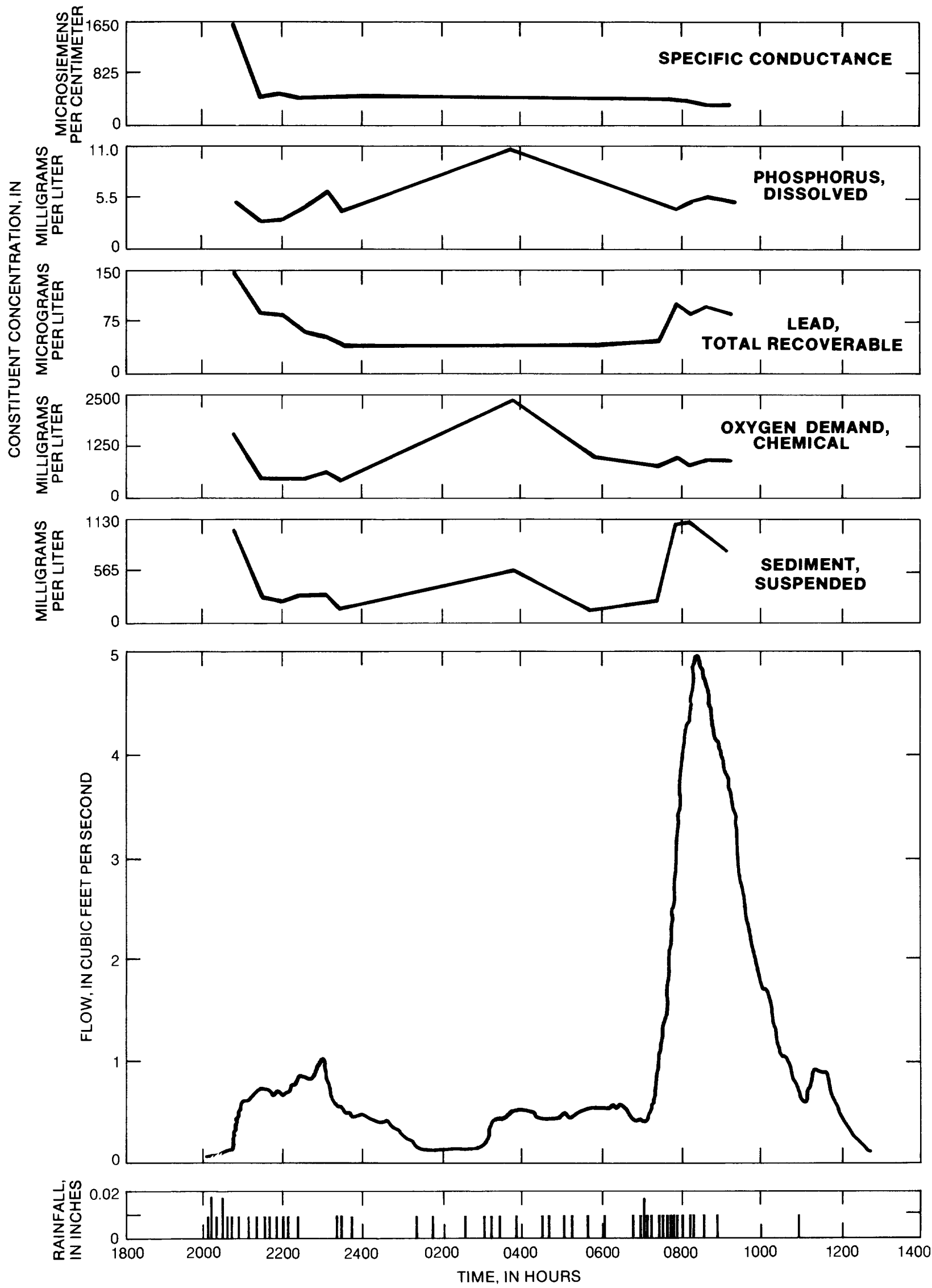

Figure 12. Typical constituent concentration plots and flow hydrographs for industrial catchment, November 12-13, 1981. 
storm runoff. The first two collected samples along with the seventh sample (3-minute collection interval between samples) were sent to the laboratory for analysis of assorted nutrient and metal constituents. The seventh sample was selected as a control sample representative of the quality of the hydrant water. Comparing the laboratory results of the first two collected samples and the control sample indicated minimal differences in concentrations. Specific-conductance readings taken of all seven collected samples also showed minimal differences. The first hydrant water to reach the monitoring point was observed to be murky, but by the time the flow was deep enough to submerge the automatic sampler intake, the water was clear.

The results of this one-time test indicate that constituent concentrations for samples collected during storms probably are not biased by storm-drain pipe residue. Although this test was done at only one location, the results are believed to be transferable to the industrial and commercial sites because their storm-drain pipes and monitoring systems were similar to the multiple-dwelling residential site. This conclusion is not transferable to the single-dwelling residential site because the storm-drain pipe generally was full of water; tests were not made for this site.

\section{Regression Analysis of Constituent Concentrations}

Simple linear regression analysis was used to investigate possible relations between constituent concentrations for each catchment. This was done using the discrete sample data and the REG procedure of SAS (Helwig and Council, 1979). Relations between specific conductance and constituent concentrations also were investigated with the intent of using the relations with specific-conductance data for storms that did not have laboratory-analyzed constituent concentrations. The estimated concentrations then were to be used in conjunction with runoff data to calculate storm constituent loads (refer to "Computation of Runoff Constituent Loads" section) for use in additional data analysis.

The regression analysis results provided relations between nutrient species concentrations, and between specific conductance and nutrient, alkalinity, and dissolved-solids concentrations for all catchments except the industrial catchment (table 17). Relations for the industrial catchment could not be determined because of unexplained variance in the specific-conductance data. Determination of relations between dissolved and total recoverable metal concentrations, and relations between specific conductance and metals, chemical oxygen demand, and dissolved and suspended organic carbon concentrations were attempted but produced no usable results except for the specific conductance and chemical oxygen demand relation shown in table 17 for the single-dwelling residential catchment.

Before developing the nutrient and specific conductance relations, initial washoff samples for all storms were eliminated from the data set. Initial concentration plots of specific conductance and nutrient concentrations indicated that a linear relation existed between the constituents, but that there also were several outlier data points that usually plotted to the right of the indicated relation line (fig. 13). Further analysis revealed that most of these outlier data were initial washoff samples, indicating that the relation does not apply during this period. These data were omitted in order to avoid having these few outlier data points that result from a small part of the total hydrograph affect the calculation of the relation that would be applied to estimate concentrations for the entire storm hydrograph. The omission of these initial washoff data points produces a relation that estimates an initial washoff nutrient concentration that probably is higher than what would be measured. However, the error associated with eliminating initial washoff sample points has a small effect on the computed total storm constituent load.

A simple linear relation did not adequately fit the dissolved nitrite plus nitrate and specific-conductance data for the single-dwelling residential catchment. Therefore, as shown in table 17, a polynomial equation was found to provide the best fit. This was the only constituent or catchment where a nonlinear relation with specific conductance occurred. Also for the single-dwelling residential catchment, one relation for each rain season was determined for dissolved ammonia plus organic nitrogen and specific conductance. These relations were found to be statistically different $(\alpha=0.05)$.

Only the first rain season data were used for developing the relations for the commercial catchment. The second rain season's data were not used because of possible adverse effects to the data caused by the construction activity adjacent to the commercial catchment (Oltmann and others, 1987).

The regression relations and the 95-percent prediction confidence limits for specific conductance and dissolved phosphorus, dissolved ammonia plus organic nitrogen, dissolved nitrite plus nitrate, and dissolved solids are shown

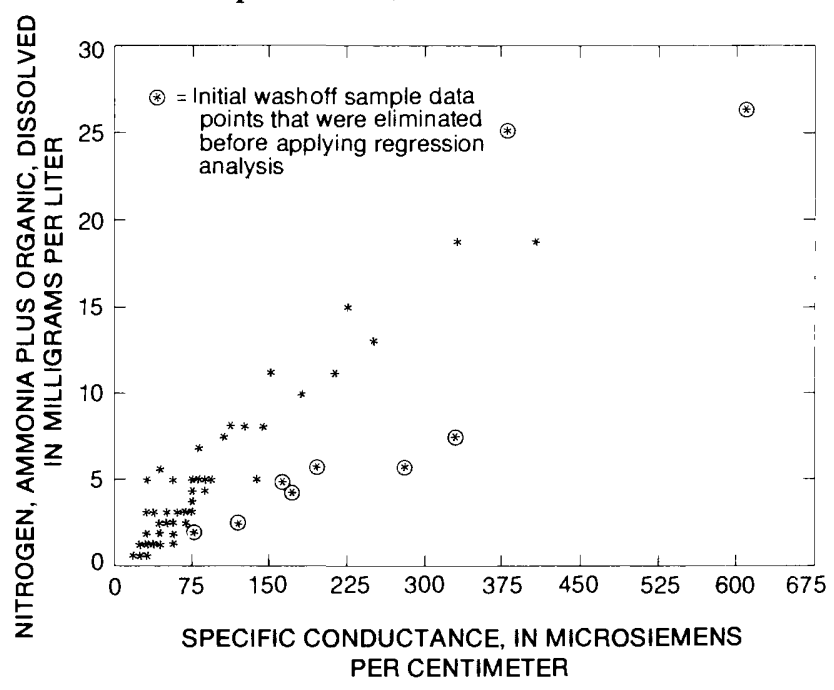

Figure 13. Relation of dissolved ammonia plus organic nitrogen and specific conductance using discrete runoff data for multipledwelling residential catchment. 
graphically in figures 14 through 16 . For the nonlinear relation between specific conductance and dissolved nitrite plus nitrate for the single-dwelling residential catchment, the predicted dissolved nitrite plus nitrate, calculated from the polynomial equation shown in table 17 , is plotted against the measured dissolved nitrite plus nitrate. These relations were used in conjunction with specific-conductance readings (Oltmann and others, 1987, table 14) to estimate constituent concentrations for use in calculating storm constituent loads.

\section{Computation of Runoff Constituent Loads}

Storm event constituent loads were computed by using runoff data and one of the three following approaches:

1. Discrete laboratory constituent concentration data and the LOADS computer program documented by Doyle and Lorens (1982).

2. Estimated constituent concentration data and the LOADS computer program.

3. Laboratory flow-weighted composited samples.
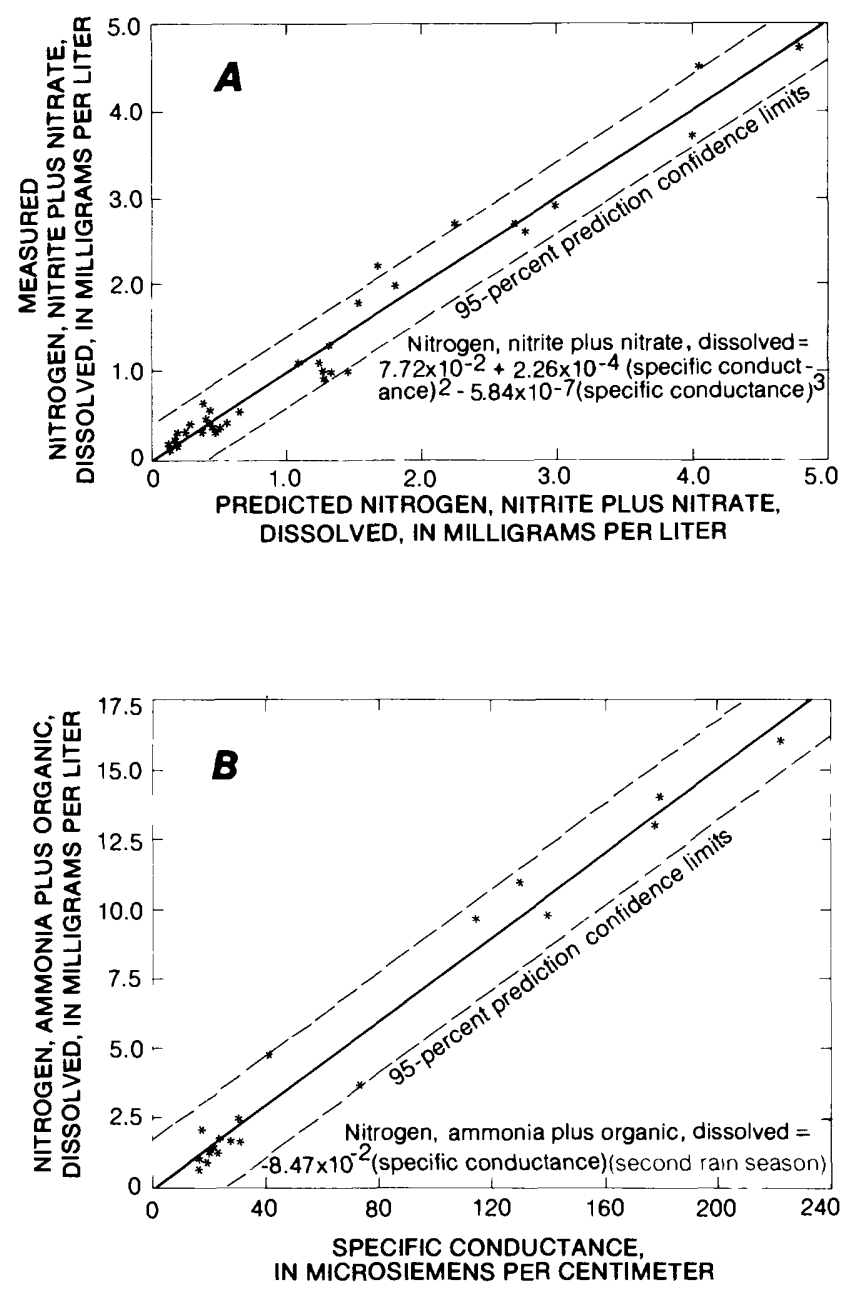

Storm-runoff constituent loads were computed for the 15 constituents for which rainfall loads were computed in addition to loads for suspended sediment, suspended organic carbon, and dissolved solids. Runoff pesticide loads were not computed because only one or two grab samples were collected per storm. The major ion pie diagrams shown in figure 10 also can be used in conjunction with the dissolvedsolids loads to provide estimates of individual ion unit loads.

The LOADS program computes a constituent load assuming that the constituent concentration varies linearly between known concentration data points. This may not be true for all cases, but if there are adequate concentration data covering the entire runoff hydrograph, the assumption is within acceptable practice. The assumption may be more precarious when using metals and suspended-sediment data because of the variation of these constituent concentrations with velocity, whereas most other constituent concentrations tend to decrease uniformly throughout the hydrograph after initial washoff (fig. 11).

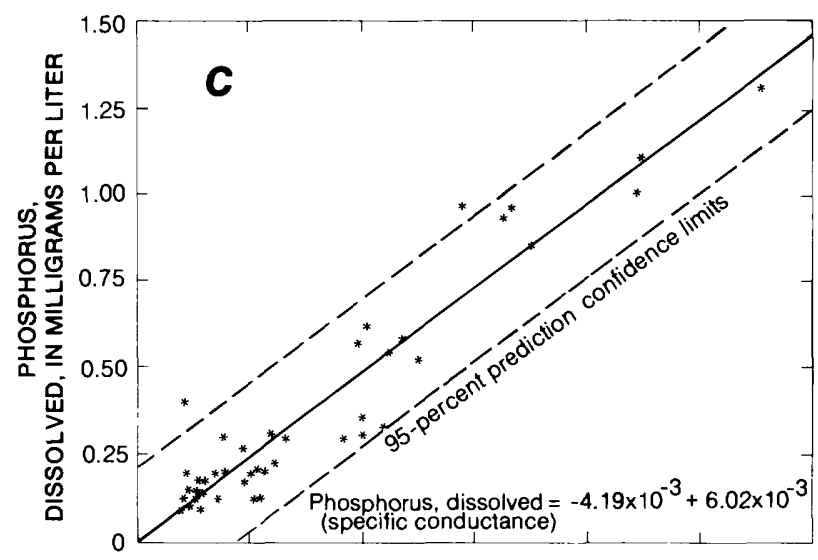

Figure 14. Results of constituent concentration and specific conductance regression analysis for the single-dwelling residential catchment. $A$, Dissolved nitrogen (nitrite plus nitrate). B, Dissolved nitrogen (ammonia plus organic). $C$, Dissolved phosphorus. $D$, Dissolved solids. 
The LOADS program computes an interval load for each runoff data point by multiplying the interval runoff volume by the constituent concentration for that data point (fig. 17). The interval runoff volume is calculated by multiplying the runoff rate by the data-record interval. For calculating interval loads before the first known concentration point, the first known concentration value is used; for points after the last known concentration point, the last known concentration value is used. The summation of the interval loads equals the storm load.

The constituent concentration data used in the LOADS program were either the results of laboratory analysis or estimated. Constituent concentrations were estimated using regression equations and field measured specific conductance, as discussed in the previous section.

Due to analytical costs, not all monitored storms could have selected discrete samples collected throughout the hydrograph analyzed individually. Instead, the sampling equipment was programmed to collect flow-weighted samples
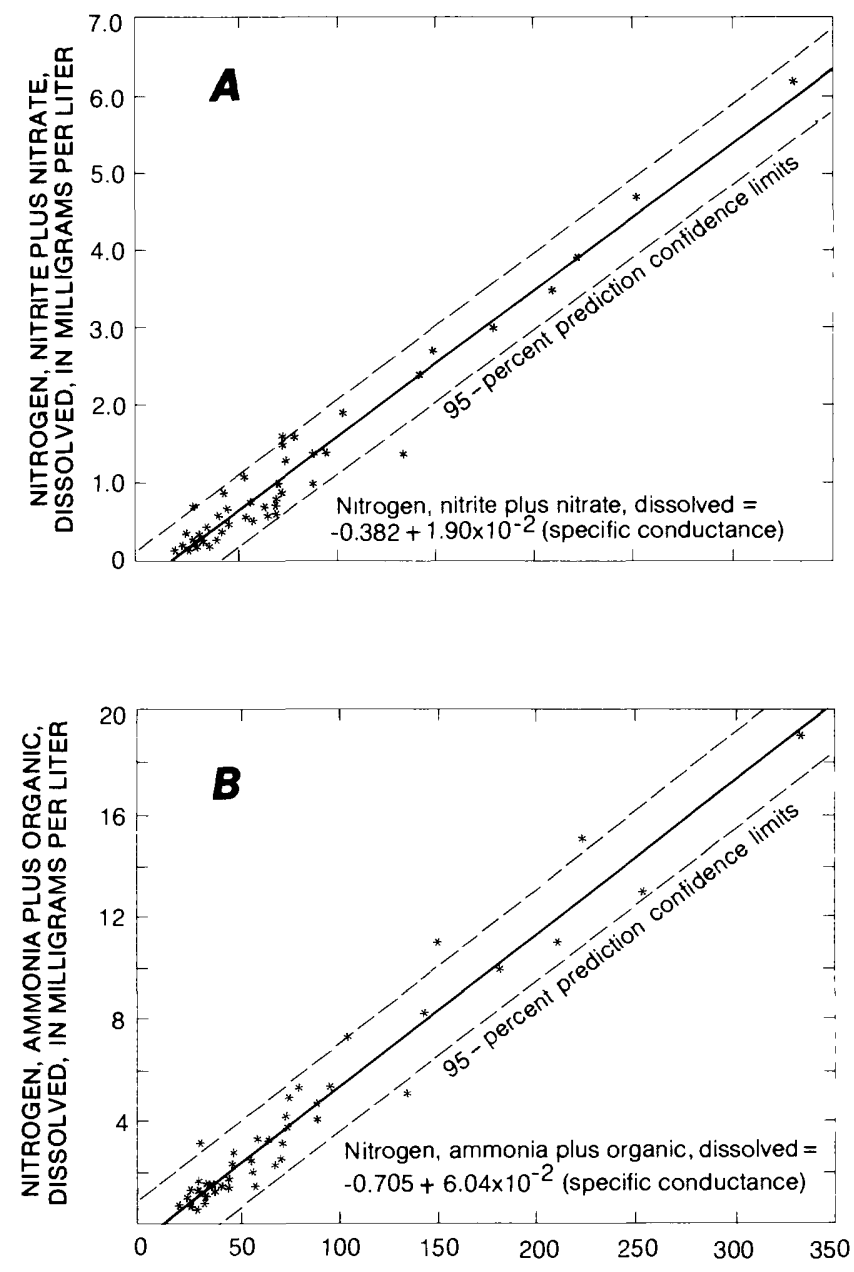

(Oltmann and others, 1987) that were composited for each site upon completion of the storm and sent to the laboratory for analysis. The laboratory constituent concentration results, equivalent to the event mean concentration (EMC), then were multiplied by the computed storm-runoff volume (table 4) to produce a storm-runoff constituent load.

All computed constituent storm loads are listed in tables 18 to 21. The EMC's for storm loads not determined from composite samples were calculated by dividing the total constituent mass discharge (load) by the runoff volume. This calculation is an attempt to eliminate some data variability caused by storm volume variability.

\section{Characterization and Regression Analysis of Constituent Event Mean Concentrations}

The first step in characterizing constituent event mean concentrations (EMC) for each catchment was to determine which variables affect a constituent EMC. Therefore, the storm characteristic data in table 4 and the constituent EMC
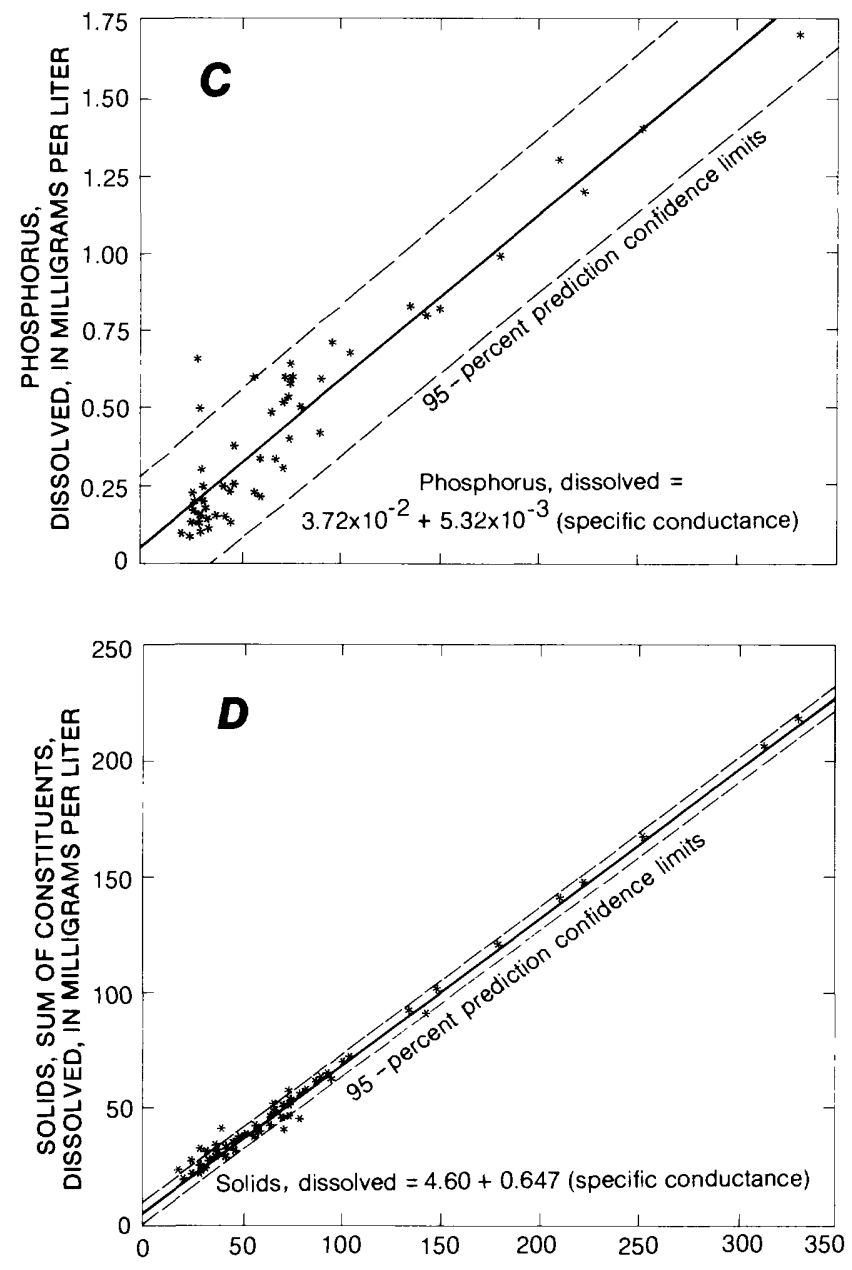

SPECIFIC CONDUCTANCE, IN MICROSIEMENS PER CENTIMETER

Figure 15. Results of constituent concentration and specific conductance regression analysis for the multiple-dwelling residential catchment. A, Dissolved nitrogen (nitrite plus nitrate). B, Dissolved nitrogen (ammonia plus organic). C, Dissolved phosphorus. $D$, Dissolved solids. 
data in tables 18 to 21 were combined and plots generated which compare EMC's and (1) number of days since first storm of rain season (SFIRST), (2) number of dry hours since last storm (DRYHRS), (3) storm-runoff volume (RUNOFF), and (4) maximum 20-minute rainfall total (MAX20).

The EMC compared to number of days since first storm of rain season (SFIRST) plots for all but the industrial catchment show that the highest EMC's for most constituents occur for the first two or three storms of the year and then tend to become quasi-constant for the remainder of the rain season (fig. 18). This seems to indicate that at least two or three storms are required to wash off the constituents that have accumulated on the catchment throughout the dry months (usually May through September) preceding the rain season. All three nutrient species plots showed this high early-storm EMC pattern as did the plots for dissolved solids and suspended sediment and most of the metal plots. The organic
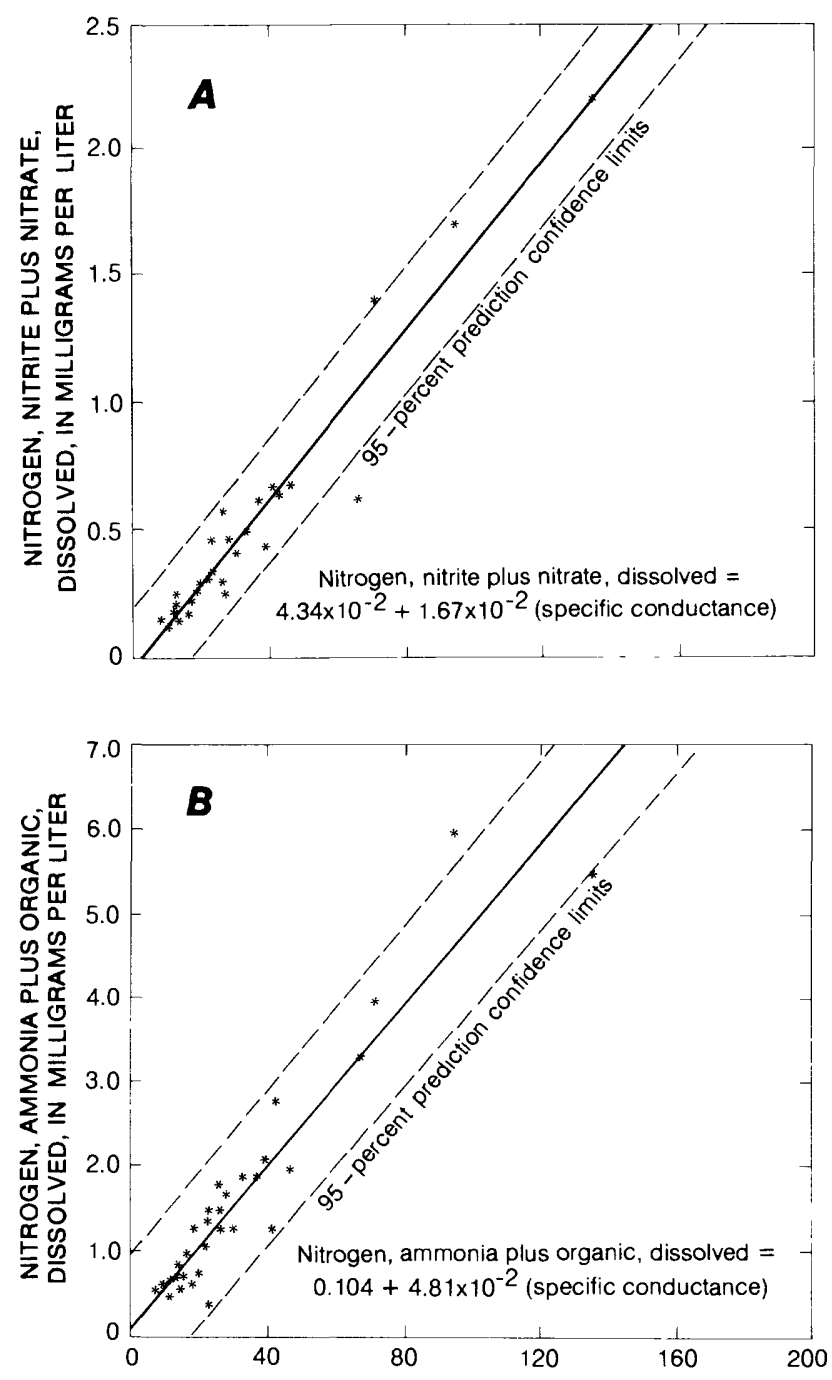

carbon, chromium, and mercury plots did not show any pattern, as did most of the industrial catchment plots.

The EMC compared to DRYHRS showed the expected trend of large EMC values associated with larger DRYHRS (fig. 19). This relation indicates that the catchment begins accumulating atmospheric dry deposition, vehicular deposition, and other sources of constituents immediately after a storm, and that the longer the time since the last storm, the more material available to be washed off.

The EMC compared to storm-runoff volume plots showed the inverse trend of smaller EMC values associated with larger runoff volumes (fig. 20). This relation indicates that if a small storm occurs that washes off only part of the accumulated pollutants, the EMC will be higher than if a large storm occurs washing off all the available pollutants. This difference in the EMC is a result of the greater degree of dilution associated with the larger runoff volumes. This
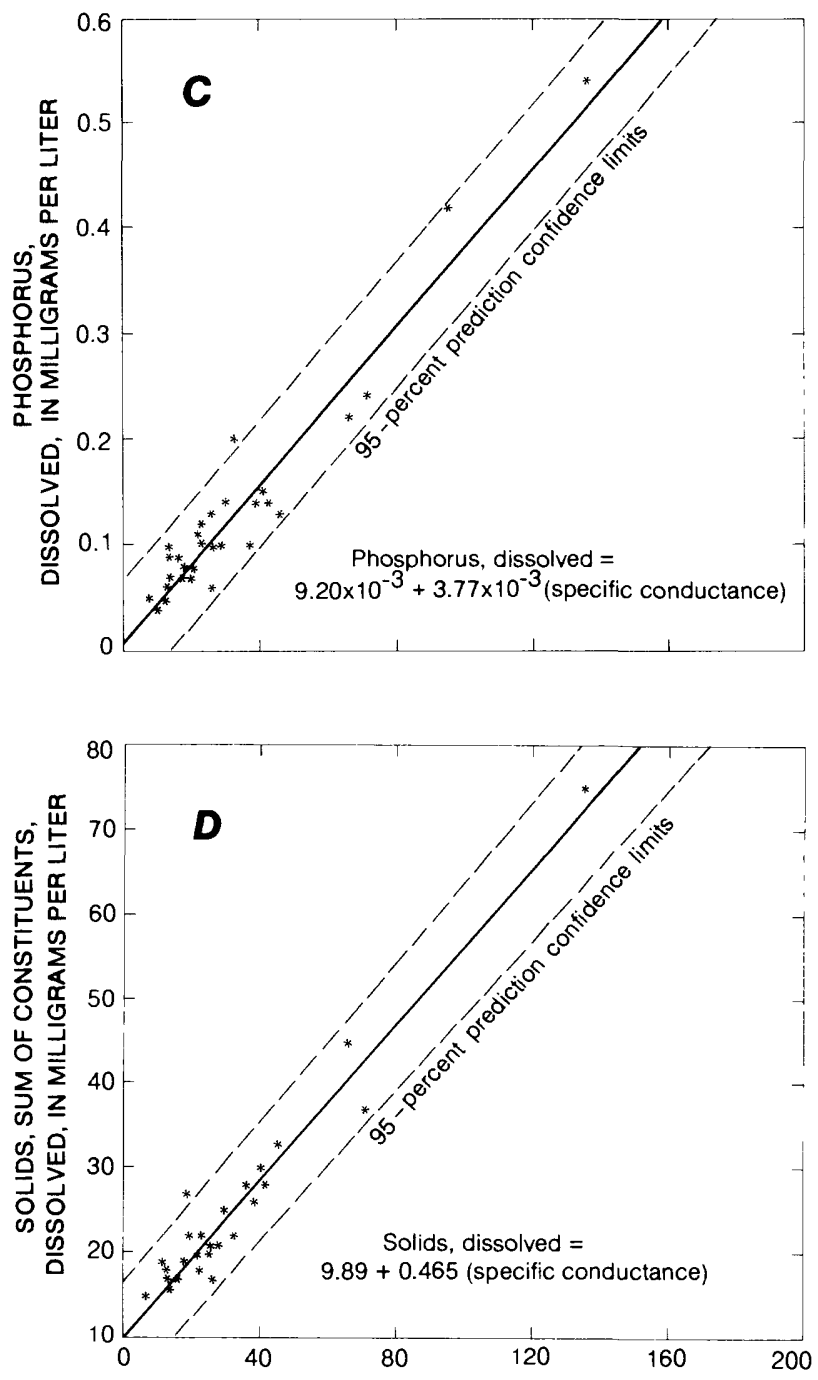

SPECIFIC CONDUCTANCE, IN MICROSIEMENS PER CENTIMETER

Figure 16. Results of constituent concentration and specific conductance regression analysis for the commercial catchment. $A$, Dissolved nitrogen (nitrite plus nitrate). B, Dissolved nitrogen (ammonia plus organic). C, Dissolved phosphorus. D, Dissolved solids. 


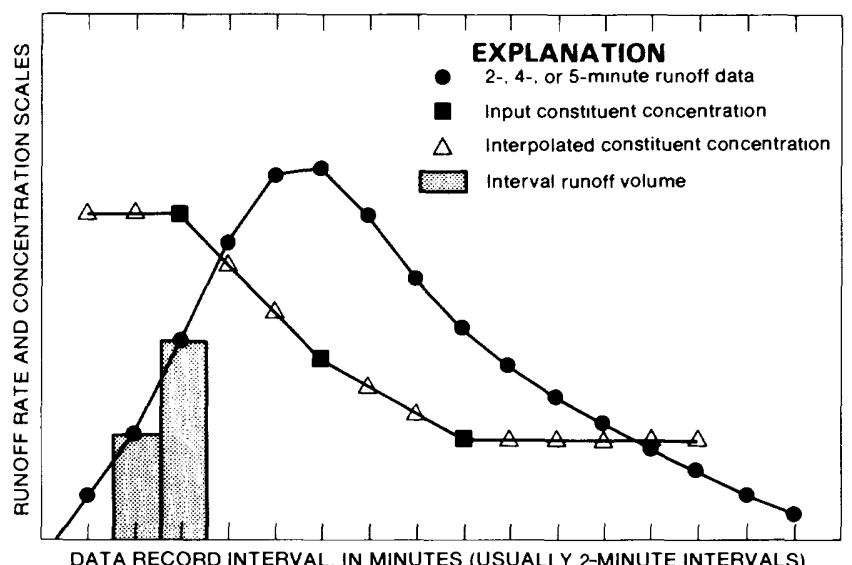

Figure 17. Computation of runoff load using LOADS program.

relation is particularly evident in the case of a highly impervious catchment, such as the commercial catchment where the accumulated constituents are rapidly washed off; as the storm progresses, the discrete constituent concentrations approach the concentrations of the rainfall. Therefore, the longer the rainfall continues, the larger the runoff volume and the lower the resulting EMC.

The EMC compared to maximum 20-minute rainfall total plots did not show any trends.

After completion of plotting the EMC data, multiple linear regression was used with constituent EMC's as dependent variables regressed against the independent variables SFIRST, DRYHRS, and storm-runoff volume. The intent of this regression analysis was to further characterize the EMC data, and to develop equations that could be used to estimate constituent EMC's for each of the different landuse types. The resultant estimated EMC could be combined with a storm-runoff volume estimated from the rainfall-runoff equations shown in figure 6 to produce constituent stormrunoff load estimates for use in future evaluation or design studies.

Before applying regression analysis, the one or two large EMC values associated with the first few storms of the rain season were eliminated from the catchment data sets. These large EMC values were eliminated because their inclusion would produce a regression equation that would provide a positive bias to EMC estimates calculated for most of a rain season's storms. In other words, the equations would be applicable for all but 2 or 3 of a rain season's 30 to 50 storms and would not be affected by those 2 or 3 storms. Because of the limited number of constituent EMC values for early rain season storms, development of EMC estimating equations for early rain season storms was not attempted.

The results of regression analyses indicated that all three independent variables were significant for some constituent EMC's for some catchments, and none of the variables were significant for other constituents. The independent variables for each catchment that were significant $(\alpha=0.05$ ) for all but 2 of the 18 constituents that have com- puted runoff loads are shown in table 22. EMC regression relations were not attempted for aluminum and manganese because of the small number of EMC values.

The predominant significant independent variables that affect nutrient EMC's are DRYHRS and RUNOFF. This indicates that material accumulates on the catchment with
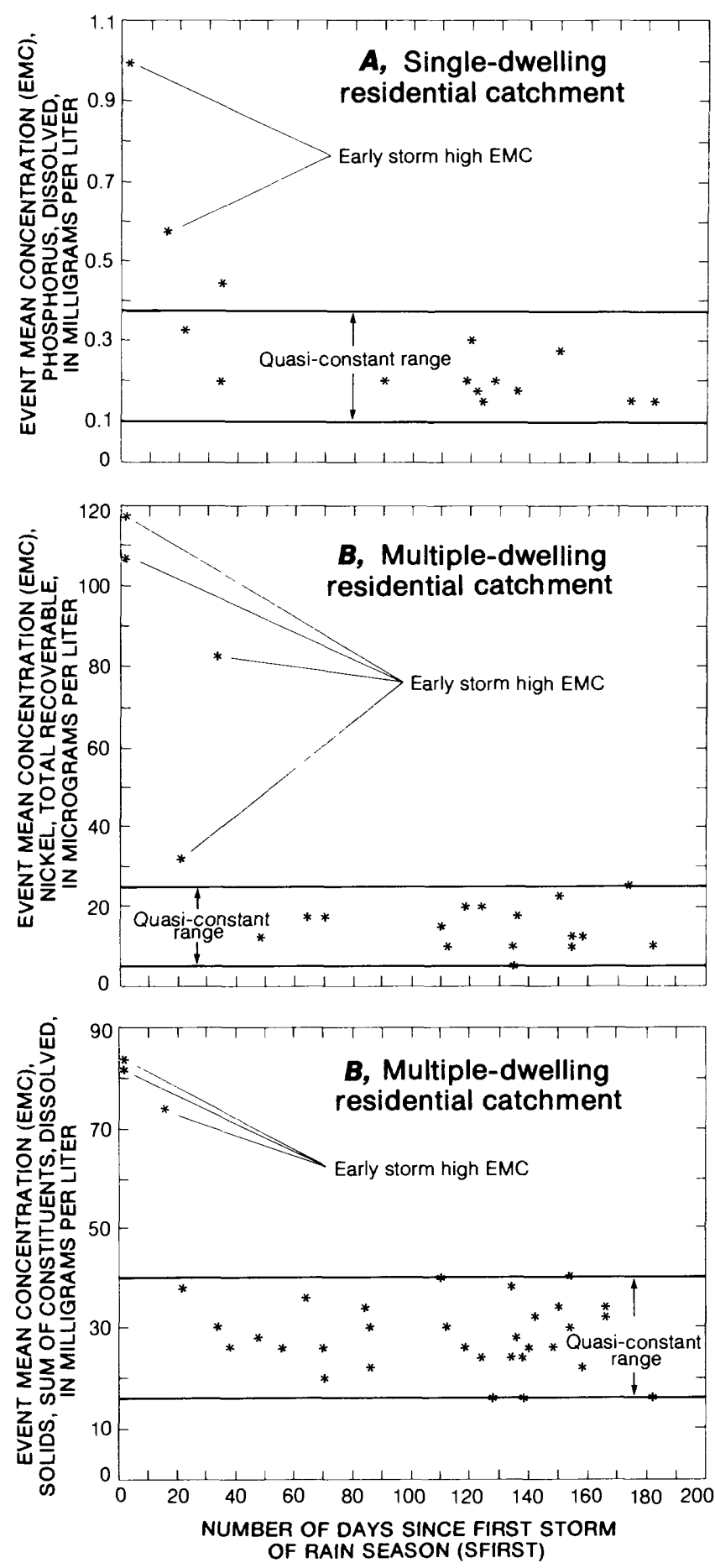

Figure 18. Comparison of constituent event mean concentrations and number of days since first storm of rain season. $A$, Single-dwelling residential catchment. $B$, Multiple-dwelling residential catchment. 
respect to time between storms (DRYHRS), and is fairly easily washed off by a storm with the EMC dependent upon the volume of runoff that dilutes the accumulated material (RUNOFF).

SFIRST is the predominant significant independent variable for the metal EMC's for the two residential catchments. SFIRST also is the only significant variable for suspended sediment. Metals are transported in association with sediment particles (Gibbs, 1977). Therefore, the significance of SFIRST seems to indicate that the entire rain season may be needed to wash the summer accumulated sediments and metals from the catchment, because sediment is more difficult to transport than other constituents. The commercial catchment is washed of summer accumulated metals during the early storms. Afterwards, only a few metal EMC's (copper and zinc) are affected by DRYHRS, indicating that these metals accumulate on the catchment between storms.

The EMC's of total arsenic, total recoverable nickel, and dissolved organic carbon were not significantly related to the three independent variables for any of the four catchments. The significant independent variables for chemical oxygen demand, suspended organic carbon, and dissolved solids varied between catchments.

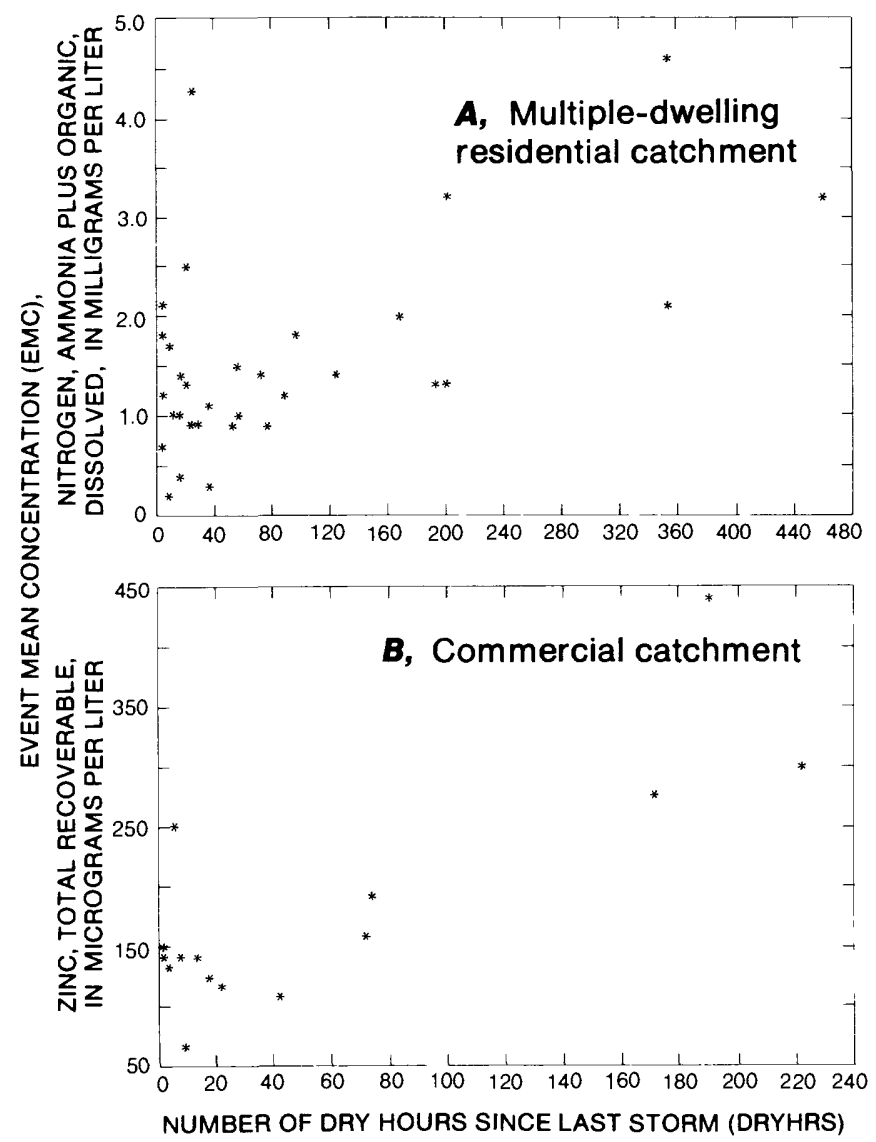

Figure 19. Comparison of constituent event mean concentrations and number of dry hours since last storm. $A$, Multipledwelling residential catchment. $B$, Commercial catchment.
The results of the EMC estimate regression analysis for each catchment are listed in table 23 for each constituent that has a significant independent variable (table 22). The "percentage of variation explained" $\left(R^{2}\right.$ adjusted for sample size) for many of the relations is fairly low; however, the estimated EMC provided by the regression equations are better estimates than using the mean of the EMC's. This is apparent by looking at how $R^{2}$ is computed:

where

$$
R^{2}=\left(S S_{t o t}-S S_{r e s}\right) / S S_{t o t},
$$

$S S_{\text {tot }}$ is the sum of the squares of the residuals about the mean of the dependent variable EMC, and

$S S_{\text {res }}$ is the sum of the squares of the residuals about the EMC regression.

Therefore, the smaller $S S_{\text {res }}$, the better the relation, and the higher the percentage of variation explained. However, unless $S S_{r e s}=S S_{t o t}$, the regression equation explains some of the variance of the dependent variable and is a better predictor of the dependent variable than using the mean of the dependent variable. The independent variables used in the regressions are shown to be statistically significant, but the $R^{2}$ values are low because there probably are other
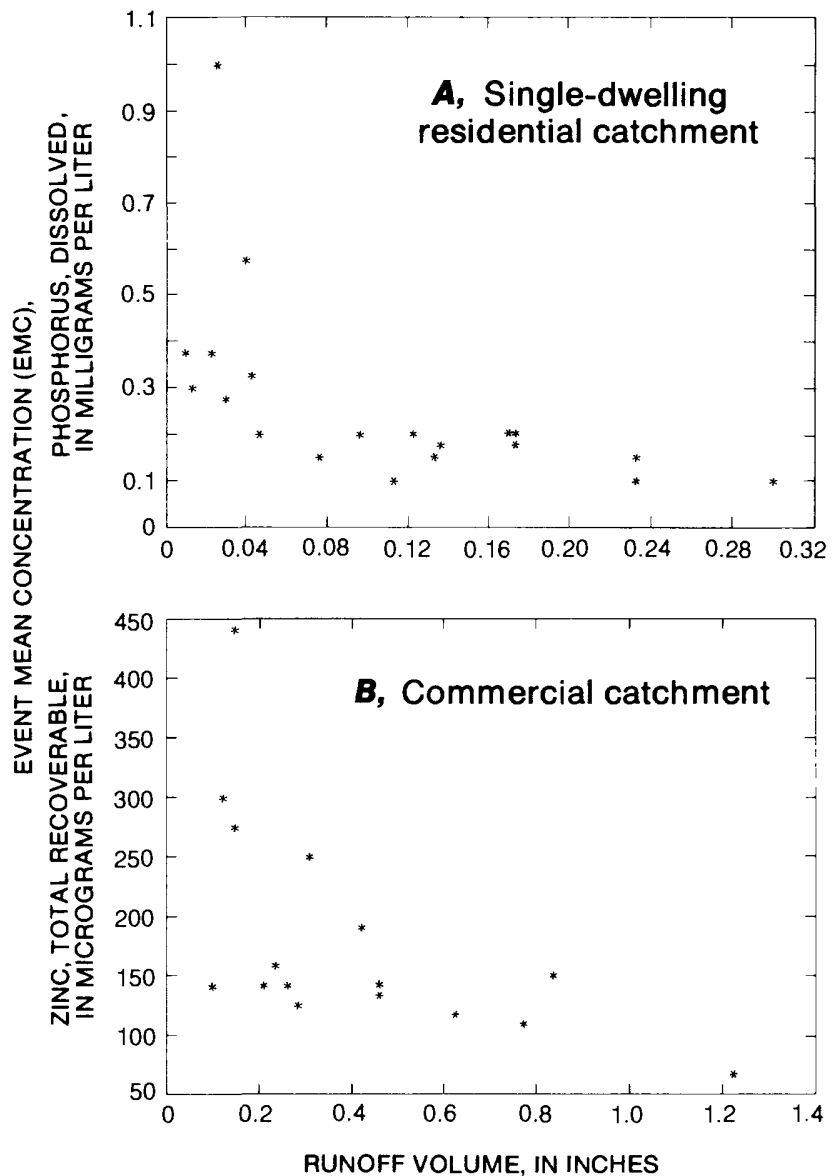

Figure 20. Comparison of constituent event mean concentrations and runoff volume. $A$, Single-dwelling residential catchment. $B$, Commercial catchment. 
variables which affect constituent EMC's for which data are not available and, therefore, were not included in the analysis.

If regression analysis did not produce useful results, the mean EMC would have to be used to estimate the EMC. A statistical summary, including means of the EMC data shown in tables 18 to 21 , is shown in table 24 . The maximum EMC for the study period also is shown in table 24 . The calculation of the mean excludes the early season high EMC's as also was done before regression analysis.

Because of the unusually high rainfall total during the second rain season, the calculated mean EMC's for some constituents and for some catchments probably are lower than the normal constituent EMC. The low mean EMC is due to the greater degree of dilution associated with the larger runoff volumes during the second rain season as previously discussed.

Inspection of the calculated EMC's for the second rain season for the commercial catchment indicates substantial increases in the EMC of suspended sediment, and total recoverable lead, iron, and nickel compared to the EMC for the first rain season. These increases probably are due to the adjacent construction activity and, therefore, were not included in the statistical summary.

\section{Estimation of Land-Use Mean Annual Constituent Unit Loads}

Estimates of mean annual constituent unit loads (pounds per acre) for each land-use catchment were calculated using the mean annual Fresno rainfall, mean rainfall-runoff coefficient, and mean constituent event mean concentrations (EMC's). Constituent unit loads were estimated for the 18 constituents that had calculated storm loads (tables 18 to 21). The estimated mean annual constituent unit loads for each catchment are shown in table 25 .

Unit load estimates were computed by multiplying the mean rainfall-runoff coefficient for each catchment (table 5) by the mean annual rainfall of 10.24 inches to produce the average annual catchment runoff. The mean annual catchment runoff was multiplied by the mean of the constituent EMC's listed in table 24 with the resultant product divided by the catchment drainage area to produce the constituent unit load.

In deriving these estimates, no attempt was made to eliminate the bias of the rainfall-runoff coefficient and EMC data caused by the extreme high rainfall total during the second rain season. The two biases were assumed to cancel each other, and that any residual effect would not significantly affect the estimates.

The rainfall-runoff coefficient data for the second rain season has a positive bias because the coefficient tends to increase with increased quantities of rainfall. This increase is due to a larger quantity of rainfall draining off the catchment after the soils become saturated and the depression areas become full. Therefore, as shown by the data in table 4 , the larger a storm, the higher the rainfall-runoff coefficient.
As previously discussed, the mean EMC data shown in table 24 probably has a negative bias. This bias is due to the greater degree of constituent dilution associated with larger runoff volumes.

It must be emphasized that transfer of these land-use constituent unit load estimates to other catchments outside and even within the Fresno area must be done with extreme caution. The monitored catchments are assumed to be representative land-use catchments for the Fresno area; however, this has not been verified. Also, data are not available from a similar land-use catchment in Fresno that could be used for comparing data variability between similar land-use catchments.

Even though most constituent concentrations for the industrial catchment are substantially higher compared to the commercial catchment, the data in table 25 shows that most unit loads for the two catchments are similar. This is due to the large difference in runoff volume from the two catchments. Phosphorus was the only constituent that had a unit load at one catchment substantially different from the other three catchments; the industrial catchment unit load is about 10 times higher than for the other catchments.

\section{Dry-Weather Runoff Samples}

During the months of August and September 1982, stage records of dry-weather runoff were periodically collected at the two residential sites in an attempt to estimate the volume of runoff during the summer months. The record for the multiple-dwelling residential catchment was fairly consistent from day to day because of the runoff from early morning lawn watering by automatic sprinkler systems. The data for the single-dwelling residential catchment were more sporadic with respect to flow periods. Based on the periodic stage records, the monthly dry-weather runoff volume for each of the residential catchments was estimated to be about 1 percent of the total annual runoff volume.

On September 3, 1982, grab samples of dry-weather runoff were collected at each of the two residential sites. The samples were sent to the laboratory for analysis of the constituents shown in table 2 . The laboratory results were compared with the mean constituent concentrations of the discrete runoff samples shown in tables 13 and 14 . The comparison showed that the dry-weather nutrient concentrations were all less, except for nitrate and nitrite plus nitrate, than the mean storm-runoff concentrations for the multiple-dwelling residential catchment. This also was true for the results of the single-dwelling residential dry-weather nutrient concentration, except for all the phosphorus species, which had concentrations two to three times higher than the mean stormrunoff concentrations.

Dry-weather metal concentrations for both catchments generally were less than the mean storm-runoff concentrations, except for arsenic which were about double.

All dry-weather major-ion concentrations for both catchments were about four to five times higher than the mean 
storm-runoff major-ion concentrations. This probably is because the dry-weather runoff water is predominantly municipal supply water taken directly from the aquifer underlying Fresno.

Only two pesticides, diazinon and malathion, had substantially higher dry-weather concentrations compared to the mean storm-runoff concentrations. The diazinon dryweather concentrations were about three times higher than the mean storm-runoff concentrations, and malathion concentrations were about double. Both pesticides commonly are used by homeowners.

\section{Atmospheric Dry-Deposition Quality Samples}

Atmospheric dry-deposition samples were collected on an approximate 60-day interval from November 25, 1981, through April 19, 1983, at one site in the industrial and single-dwelling residential catchments. A statistical summary of these samples for each of the two sites is presented in tables 26 and 27.

Dry-deposition data are quite variable. Experience has shown that the amount of material collected in a drydeposition collector bucket is highly affected by the location of the bucket with respect to the ground and street, wind conditions, and the activity in the surrounding area. The two deposition collectors used in this study were mounted in similar positions about 10 feet above the ground on the roof of the studies' instrumentation shelters and about 30 to $\mathbf{4 0}$ feet from light traffic-density streets. This similar positioning decreases some of the data collection variability between sites, but the collected data are unlikely to represent dry deposition over the entire catchment; therefore, catchment dry-deposition loads were not computed. Because of the variability of dry-deposition data, the following discussion will be more of a qualitative nature than quantitative even though quantitative numbers will be used.

The conventional reporting units for dry-deposition data are mass-concentration units (tables 26 and 27). Interpretation of the data using these units can be misleading. Plots of total recoverable lead from dry deposition in massconcentration units compared to time for the two sites are shown in figure 21 . The plots show the highest lead concentrations occurring during the first few months of the rain season with the lowest concentrations occurring during the spring months. The other plot shown on the figure is the deposition rate for the sample collection period of the total dry-deposition material collected. These plots show the total dry-deposition rate to be higher during the dry-weather periods than during the wet-weather periods. They also show that the total dry-deposition rate plots are completely out of phase from the mass-concentration plots. A lead deposition rate was calculated for each sample. The results showed a mean deposition rate range of 1.3 to $3.3 \mu \mathrm{g} / \mathrm{d}$ for the industrial site and 2.1 to $4.8 \mu \mathrm{g} / \mathrm{d}$ for the single-dwelling residential site. These small ranges indicate that the lead deposition rate is fairly uniform throughout the year. Therefore, the lead mass-concentration data and all other constituent mass-concentration data are significantly affected by the bulk dry-mass deposition rate at the sampling location.

It is noteworthy that the lead mass-concentration plots for the two sites show the same cyclic pattern as did plots of other constituent mass concentrations with time (fig. 22). This cyclic pattern implies that the deposition rate of most of the constituents also is fairly uniform throughout the year. The consistency of the plots for the two sites indicate that the patterns of dry deposition at the two sites are quite similar.

\section{Street-Surface Particulate Quality Samples}

Street-surface particulate samples were collected using a stainless steel canister shop vacuum and a random stratified data collection network (Oltmann and others, 1987) for each of the four catchments. The initial intent of collecting the samples was to define a catchment particulate buildup curve, and to determine which constituents at what concentrations are present on the street surfaces. It became evident very early that the definition of a particulate buildup curve was not possible because of the inaccuracies of data collection. For example, the 20 to 25 curb-to-curb samples (Oltmann and others, 1987) collected for each catchment and composited for laboratory analysis represents only about 0.1 percent of the catchment street-surface area. The multipledwelling residential and industrial catchments often had small sand and silt deposits in the gutters because of erosion from adjacent slopes. If the vacuum got too close to these deposits, the large amount of material which could be inadvertently collected compared to the amount collected from the other curb-to-curb samples could bias the sample. Because of these types of errors, no street-surface particulate loads will be computed. A statistical summary by catchment of the laboratory constituent concentration data for the analyzed samples is presented in tables 28 through 31 .

The high constituent concentrations for some of the metals and organic constituents obtained at the commercial catchment probably are a result of the parking lot being commercially swept daily. The sweeper removes the large gravelsize material, but is unable to remove all the fine-grained material. There is a greater percentage of particulate surface area per volume of material for fine-grained material compared to large-grained material. Metals and organics tend to adsorb to the surface of fine-grained particulate material; therefore, the constituent mass concentration values for the commercial catchment are considerably higher than for the other three catchments. These data do not signify, however, that the surface of the commercial catchment contains larger amounts of constituents than the surface of the other three catchments. 


\section{Comparison of Rainfall and Runoff Quality Data}

Constituent rainfall loads (tables 10 and 11 ) and runoff loads (tables 18 to 20) for the industrial, single-dwelling residential, and multiple-dwelling residential catchments were combined into one data set to investigate the relation between catchment constituent rainfall and runoff loads. Rainfall quality data are available only at the industrial and singledwelling residential sites, but because the single-dwelling
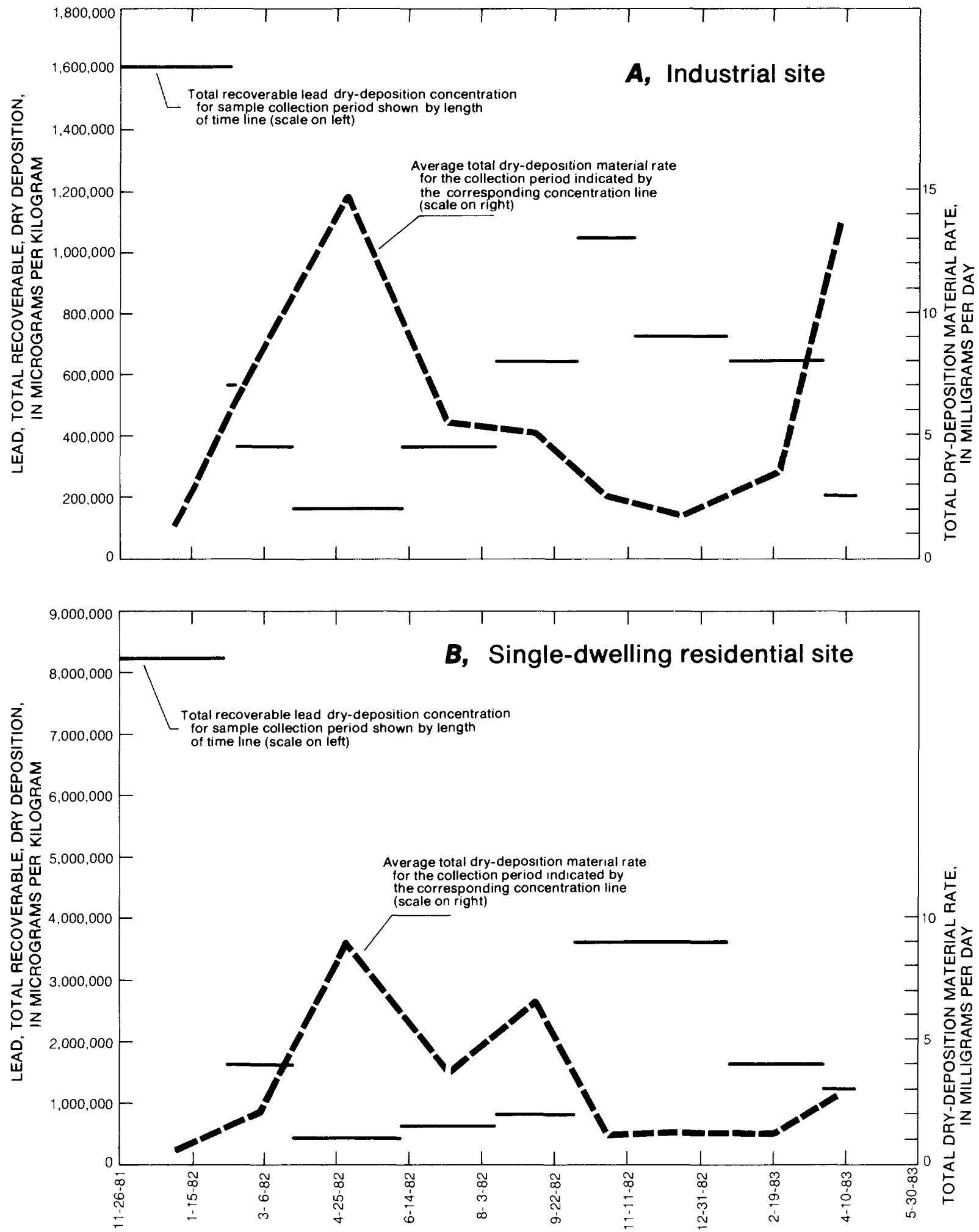

Figure 21. Comparison of total recoverable lead for atmospheric dry deposition and total dry-deposition material rate with time. $A$, Industrial site. $B$, Single-dwelling residential site. 
residential and multiple-dwelling residential catchments are less than 0.75 mile apart, the rainfall quality data collected at the single-dwelling residential site are assumed representative of the rainfall quality for the multiple-dwelling residential catchment. Rainfall quality data for the single-dwelling residential site were not used for the commercial catchment because the catchments are 2 miles apart, and the rainfall quality data may not be transferable for that distance.

The comparison between rainfall loads and runoff loads was done assuming that the rainfall load constituents would
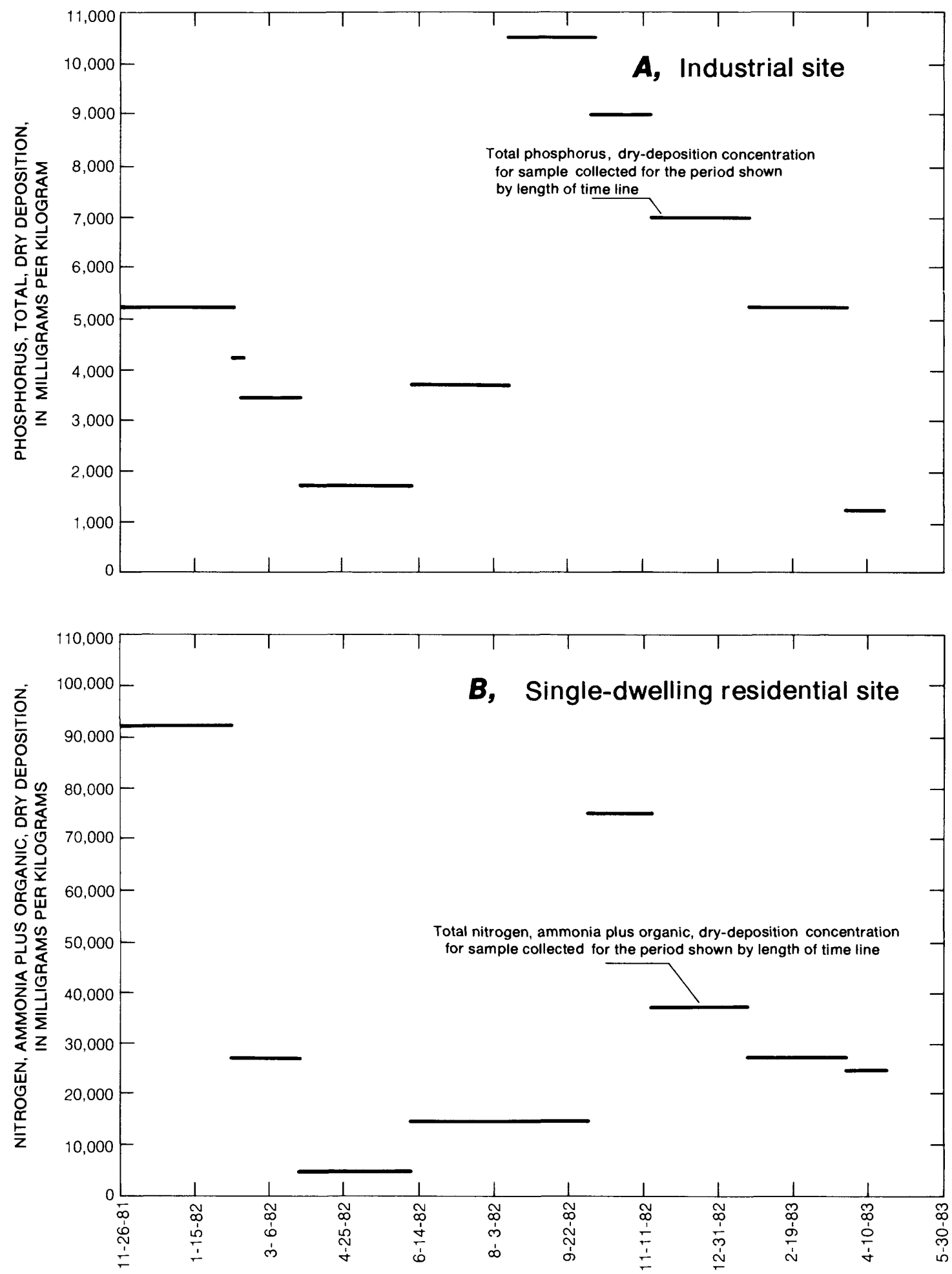

Figure 22. Comparison of constituent atmospheric dry-deposition concentrations with time. $A$, Industrial site. $B$, Single-dwelling residential site. 
not be altered in any way during runoff. The rainfall loads shown in tables 10 and 11 represent the total amount (in pounds) of a constituent that landed on the catchment for that particular storm. In order to compare these loads with runoff loads, the rainfall load was multiplied by the rainfall-runoff coefficient (table 4) for that particular storm to provide that part of the rainfall load which drained off the catchment. These rainfall drainoff loads and runoff loads for selected constituents for the industrial and two residential catchments, and the percentage of the runoff constituent load attributable to rainfall are shown in table 32 . The rainfall loads of the multiple-dwelling residential catchments were determined by adjusting the rainfall loads for the single-dwelling residential catchment (table 11) based on drainage area difference before multiplying by the rainfall-runoff coefficient. Rainfall constituents for which most of the concentrations were less than the analytical detection limit were not used. Because of the high degree of unexplained variability in the percentage rainfall load data and the small number of observations, the median value was chosen for comparison purposes.

Comparing the median percentage rainfall-load data for organic nitrogen plus ammonia and nitrite plus nitrate indicate that the two residential catchments are similar. Both show that a high percentage of the runoff load for these two constituents is attributable to rainfall (single-dwelling residential, 47 and 42 percent, respectively; multiple-dwelling residential, 56 and 44 percent, respectively). The median percentage rainfall load for the industrial catchment for these two constituents showed much lower values (10 and 25 percent, respectively) compared to the two residential catchments. Because a statistical difference was not found between the rainfall quality data for the industrial and single-dwelling residential sites for nitrite plus nitrate (table 9), the rainfall loads also should be equivalent. Therefore, the lower percentages are due to the higher nitrite plus nitrate runoff loads for the industrial catchment compared to the residential catchments. Ammonia plus organic nitrogen was statistically different in rainfall between sites (table 9). However, the runoff load for the industrial catchment is about five times larger than for the single-dwelling residential catchment (table 25), which explains the large difference in percentage of runoff load attributable to rainfall. Phosphorus shows the same relation between catchments as the nitrogen species, however, the rainfall percentages are all 10 percent or less.

The remaining constituent data shown in table 32 also show that the rainfall load contribution is smaller for the industrial catchment than the residential catchments, except for total recoverable lead. This reversal of the trend is because lead is one of the few constituents that has lower runoff concentrations for the industrial catchment compared to the residential catchments (table 24 ). The difference between constituent median rainfall percentage for the two residential catchments is due to the variation in the constituent runoff loads at the two catchments. For example, the multipledwelling residential catchment event mean concentration
(EMC) for total recoverable iron (table 24) is almost three times higher than for the single-dwelling residential catchment. Therefore, the median rainfall percentage for the multiple-dwelling residential catchment is about one-third that of the single-dwelling residential catchment.

The difference between the rainfall drainoff load and the storm-runoff load represents the load attributable to catchment washoff. Some of the sources that contribute to this washoff load consist of atmospheric dry deposition, vehicular deposition, animal waste, fertilizers, and overland flow of erosion material.

Average ion concentrations in milliequivalents per liter for all sampled storms during the study at the three rainfall sampling sites are shown in a pie diagram (fig. 23). When comparing this diagram with those shown for runoff in figure 10 , it is evident that the rainfall composition is quite different from the composition of runoff from the industrial catchment, but similar to the other three land-use sites. The effects of basin washoff on ionic composition is much greater for the industrial catchment than any of the other three catchments and is indicative of the land-use characteristics in the industrial catchment.

\section{Pesticides}

Because Fresno is in the highly agricultural San Joaquin Valley, pesticides commonly used in the area were analyzed for in runoff from each catchment, rainfall, atmospheric dry-deposition, and street-surface particulates. For catchment runoff, discrete grab samples were collected during storms to avoid contamination by the organic-based components of the automatic sampling equipment. Precipitation

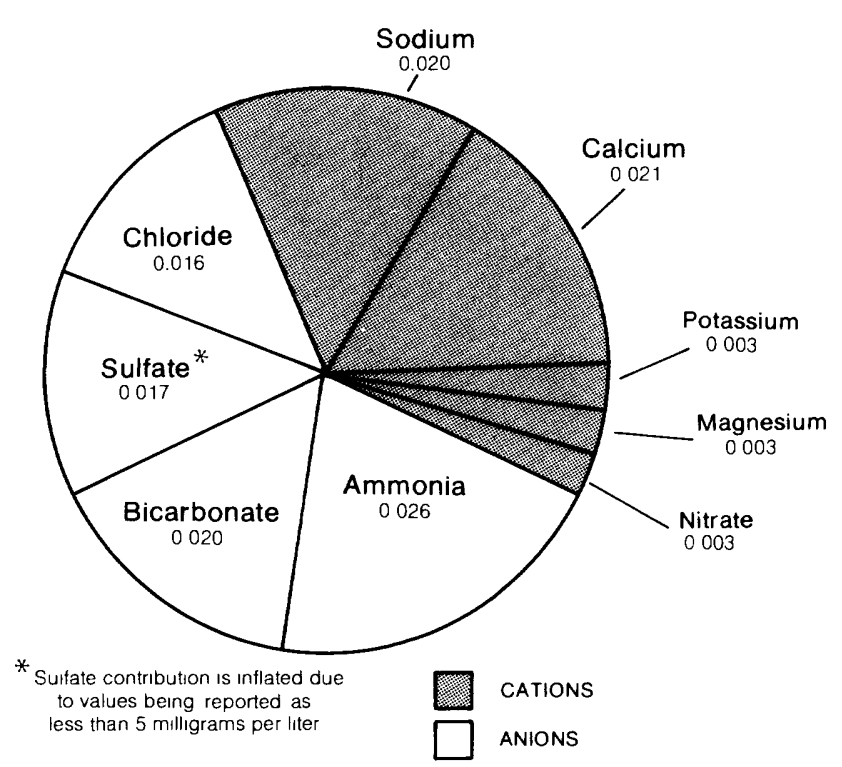

(AVERAGE OF ALL SAMPLES, IN MILLIEQUIVALENTS PER LITER)

Figure 23. Average concentrations of dissolved major ions for rainfall for all monitored rainfall sites. 
and dry-deposition samples were collected using metal and glass samplers that were placed in position by hand before and after storms. Dry-deposition samples were difficult to collect because of trace amounts of precipitation that would unexpectedly occur, washing the sample off the collector. Automatic wetfall/dryfall collectors were not used for the same reasons mentioned above for catchment-runoff samples. Street-surface particulate samples were collected using a high-powered stainless steel vacuum at selected locations in each basin. A detailed discussion of collection methods is in Oltmann and others (1987).

The pesticides analyzed during the study for each of the four data types are shown in table 33. Not all the pesticides in the list were analyzed for each data type (rainfall, runoff, dry deposition, and street particulate). A statistical summary of pesticides identified in samples from all three of the rainfall monitoring sites is shown in table 34 . Comparisons between these sites showed no statistically significant difference $(\alpha=0.05)$ for any of these pesticides. See page 13 for a discussion of the statistical techniques used.

Results from the laboratory monitoring site are not used in the following discussion because data were collected only during the second year to verify results at the other two sites. The organophosphorus compounds, parathion, malathion, and diazinon, were the most prevalent in the rainfall during the study period. The occurrences of parathion and diazinon were shown to be correlated $(R=0.71)$ using PROC CORR of SAS (Helwig and Council, 1979). These two insecticides are used in the San Joaquin Valley primarily as dormant sprays on fruit trees, which probably accounts for their occurrence in the rain. The most common application method used is a high-volume, truck-mounted sprayer that tends to suspend large quantities of spray into the air, facilitating movement by wind currents. Some diazinon was detected in the early season storms in September, October, and November (fig. 24), but parathion did not become evident until the late December and January storms (fig. 24). Both compounds were detected throughout the remainder of the rain season. The concentrations observed seem to be dependent on the storm rainfall total and the length of time since the last storm. Concentrations generally were higher during the first year, but loadings generally were higher during the second year due to the higher storm rainfall totals. An example of this can be seen for parathion in figure 25. Malathion, whose usage has decreased in recent years, occurred in low concentrations during the study, and its occurrence was more variable than either parathion or diazinon (fig. 26).

The organochlorine insecticides and the chlorophenoxy acid herbicide, 2,4-D, were not detected as often or in as large a concentration as parathion or diazinon. Insecticides in the organochlorine group and 2,4-D are applied primarily by aircraft in the San Joaquin Valley. Organochlorine insecticides have been reported in rainfall in previous studies including Bevenue and others (1972), Eisenreich and others (1981), and Strachan and Huneault (1979). Most of the oc- currences in this study were during the first year when there was considerably less rainfall than during the second year. Chlordane was detected during the first sampled storm of the study and once subsequent to that at the industrial site. The rest of the time it was at or less than the detection limit of $0.10 \mu \mathrm{g} / \mathrm{L}$ (fig. 27). Methoxychlor was greater than the detection limit only during March of both years (fig. 27). Endosulfan was detected during March of both years and at the single-dwelling residential site in October of the second year (fig. 27). Lindane was detected only once at the singledwelling residential site and seven times at the industrial site, five of those times coming during the first year of the study (fig. 27). The chlorophenoxy acid herbicide, 2,4-D, was detected during January to March of both years (fig. 28).

Of the eight pesticides detected in the rain, only parathion, diazinon, malathion, chlordane, lindane, and 2,4-D occurred regularly in the catchment runoff grab samples. A statistical summary of the six pesticides in runoff is shown in table 35. All other pesticides detected in runoff occurred very infrequently in each of the four catchments. Chlordane occurred more frequently in the catchment runoff than it did in the rainfall. The use of this product in urban areas to con-

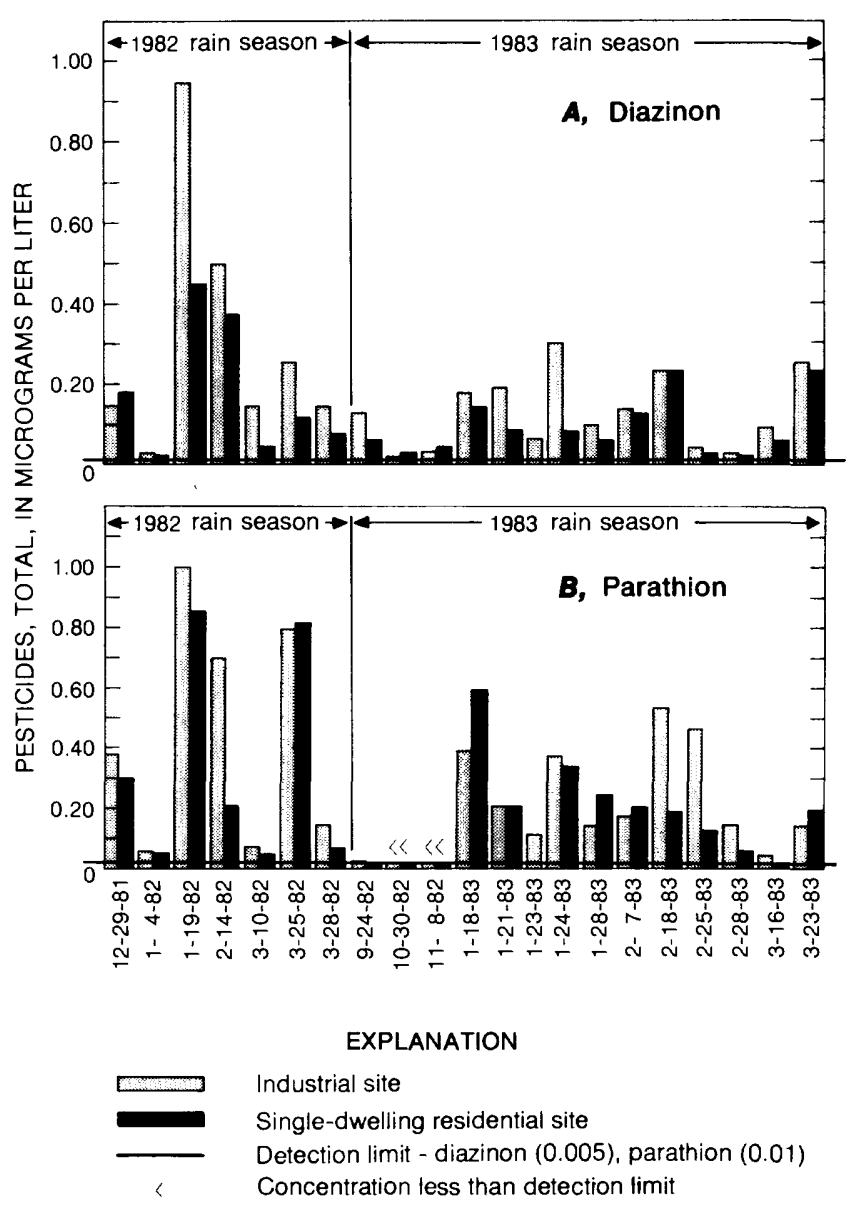

Figure 24. Diazinon and parathion concentrations in stormcomposite rainfall samples collected at industrial and singledwelling residential sites. $A$, Diazinon. $B$, Parathion. 


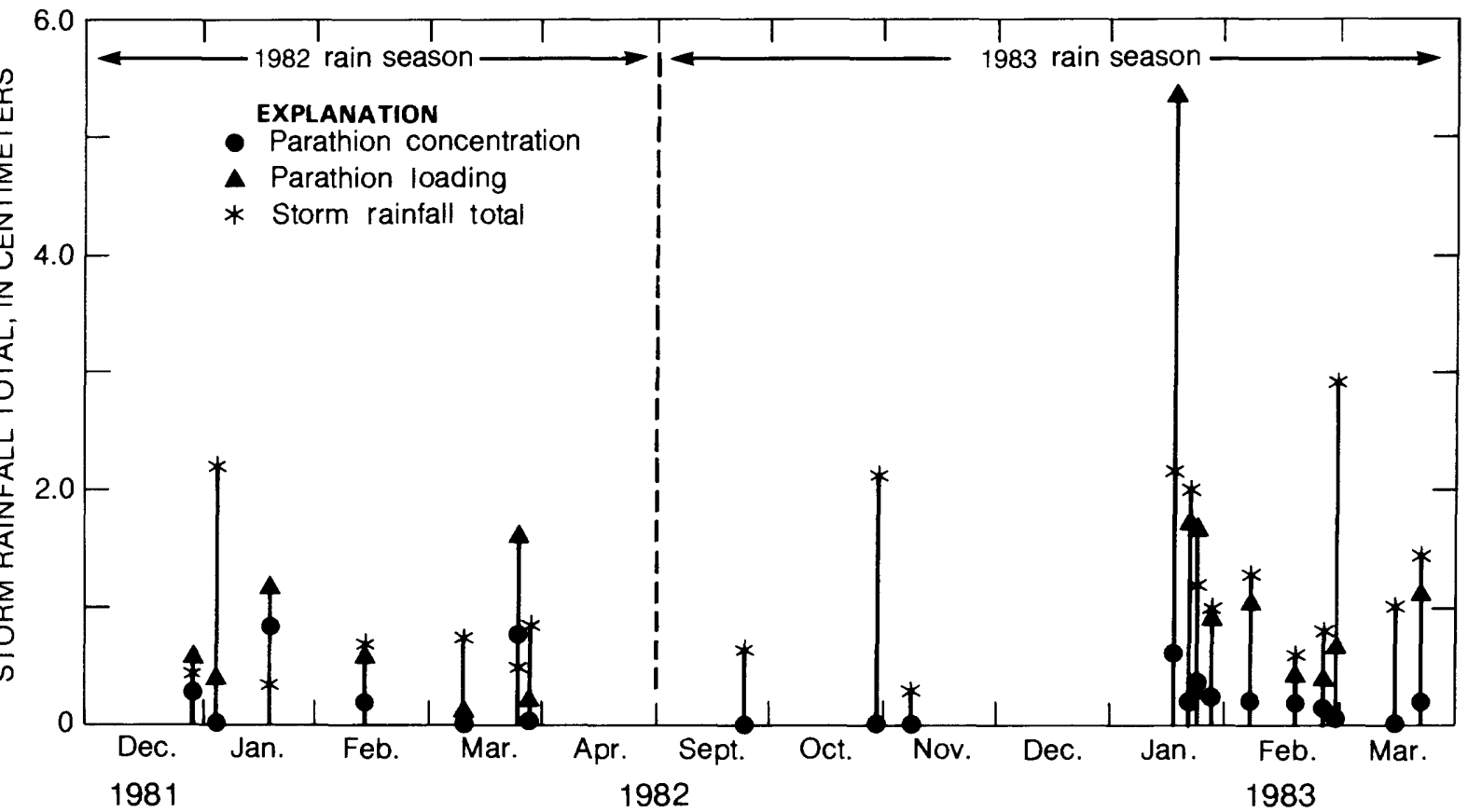

Figure 25. Parathion concentration, parathion loading, and storm rainfall totals at the single-dwelling residential site.

trol ants and termites may be the reason that its occurrence is more frequent in runoff. Diazinon and malathion are readily available products for use in yards and gardens in urban areas as well as being used extensively in agriculture. Both of these occurred as frequently in runoff from all four catchments as they did in the rain. Parathion also occurred frequently in runoff from each catchment. Because of its primarily commercial agricultural uses and high concentrations in the rainfall, it probably is being imported into the urban area from surrounding agricultural areas. Lindane is used in residential and structural pest control. The herbicide 2,4-D is used commercially in the surrounding agricultural communities.

The only pesticide that seems to correlate with land use is chlordane. The single-dwelling residential, multipledwelling residential, and commercial catchments all had more frequent occurrences of chlordane than did the industrial catchment.

All of the pesticides detected in atmospheric dry deposition also were detected in catchment runoff and rainfall (table 33). In addition, most pesticides detected in the street-surface particulate samples were detected in the catchment runoff (table 33). A complete listing of all pesticide data are given in Oltmann and others (1987).

\section{COMPARISON WITH WATER-QUALITY CRITERIA AND STANDARDS}

The city of Fresno gets its drinking water from ground water that is in part recharged by urban runoff collected in recharge basins. Because of this, there is interest in how the quality of the urban runoff compares with drinking water standards. Water that exceeds specific criteria prior to recharge will not necessarily pose problems to the groundwater supply, but may require close monitoring. Schematic plots and criteria values of constituents for which there are drinking water regulations established by the U.S.

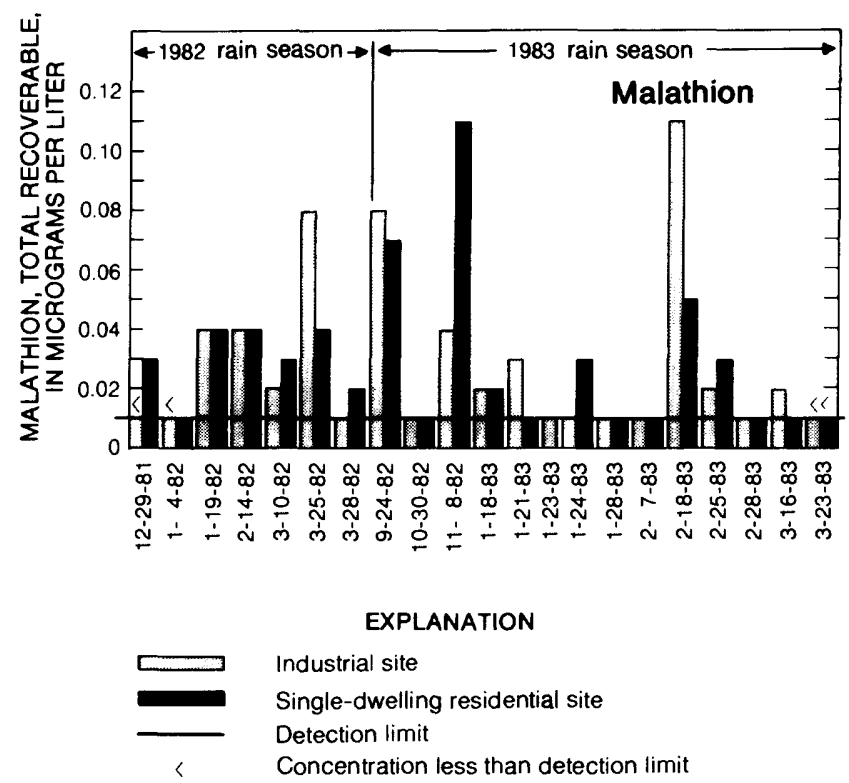

Figure 26. Malathion concentrations in storm-composite rainfall samples collected at industrial and single-dwelling residential sites. 

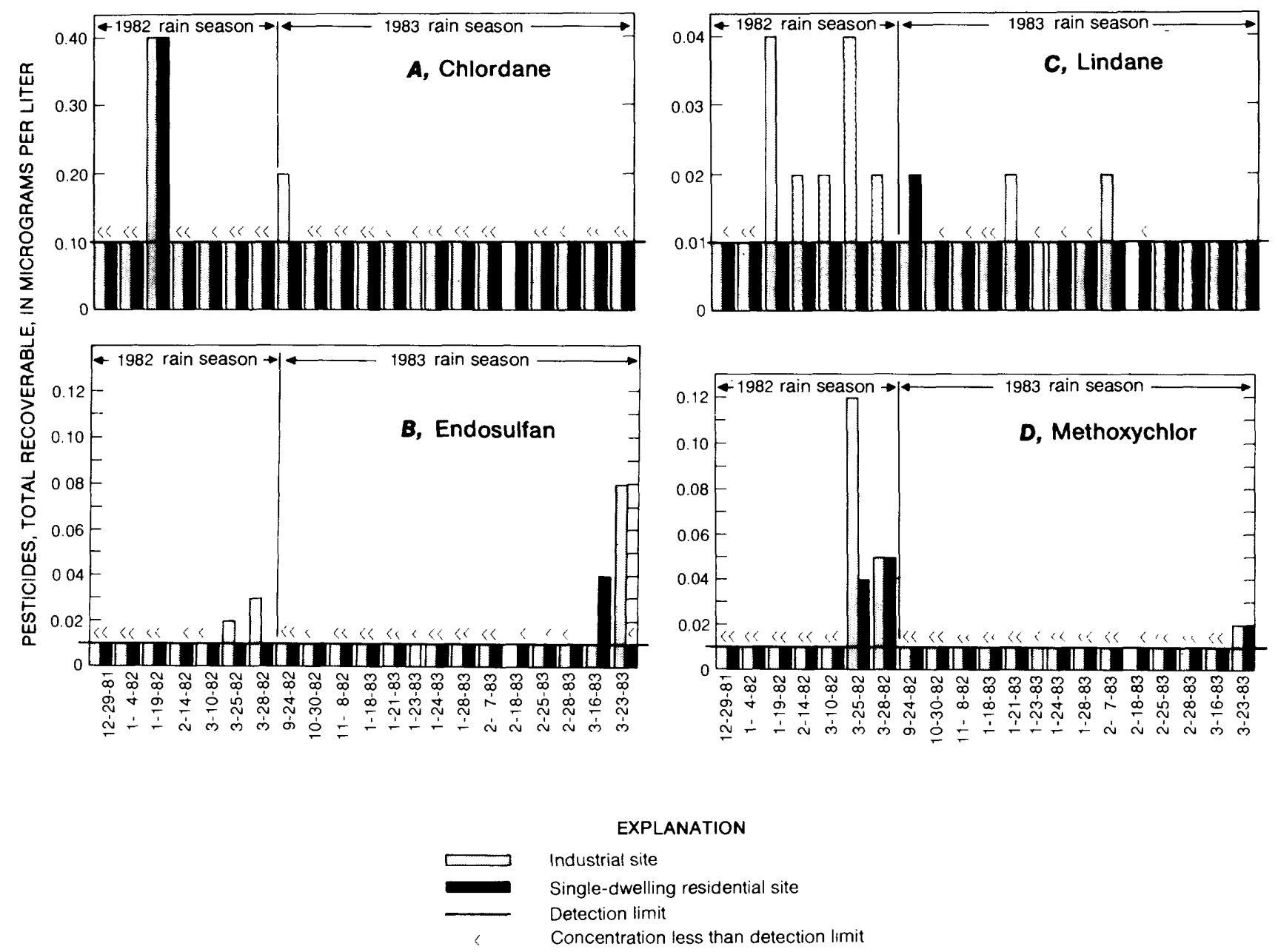

Figure 27. Organochlorine insecticide concentrations in storm-composite rainfall samples collected at industrial and single-dwelling residential sites. A, Chlordane, B, Endosulfan. C, Lindane. D, Methoxychlor.

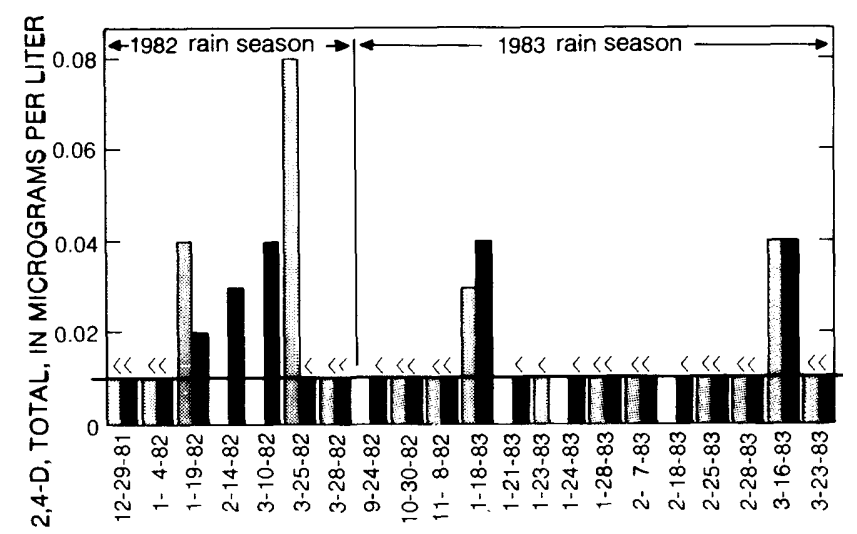

EXPLANATION

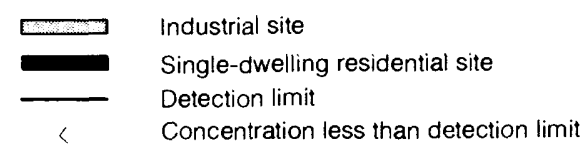

Figure 28. 2,4-D concentration in storm-composite rainfall samples collected at industrial and single-dwelling residential sites.
Environmental Protection Agency $(1977,1979)$ in the Safe Drinking Water Act, Title 40, parts 141 (primary) and 143 (secondary) are shown in figures 29 and 30 . Mandatory limits in the Safe Drinking Water Act are referred to as primary drinking water regulations (fig. 29), and the recommended limits are referred to as secondary drinking water regulations (fig. 30).

\section{SUMMARY}

The Fresno Metropolitan Flood Control District (FMFCD) has routed urban stormwater runoff to local manmade retention basins since 1956 . These 10 - to 15 -acre basins allow the runoff water to percolate through the underlying soil where it recharges the aquifer that underlies the city of Fresno. The aquifer is the source of the city's domestic water supply and has been designated as a "Sole-Source Aquifer" by the U.S. Environmental Protection Agency (EPA).

FMFCD received a grant from EPA under the National Urban Runoff Project (NURP) to investigate the potential environmental effects associated with recharge of urban 
stormwater runoff. FMFCD requested the U.S. Geological Survey to characterize stormwater runoff from four different land-use catchments and requested the U.S. Department of
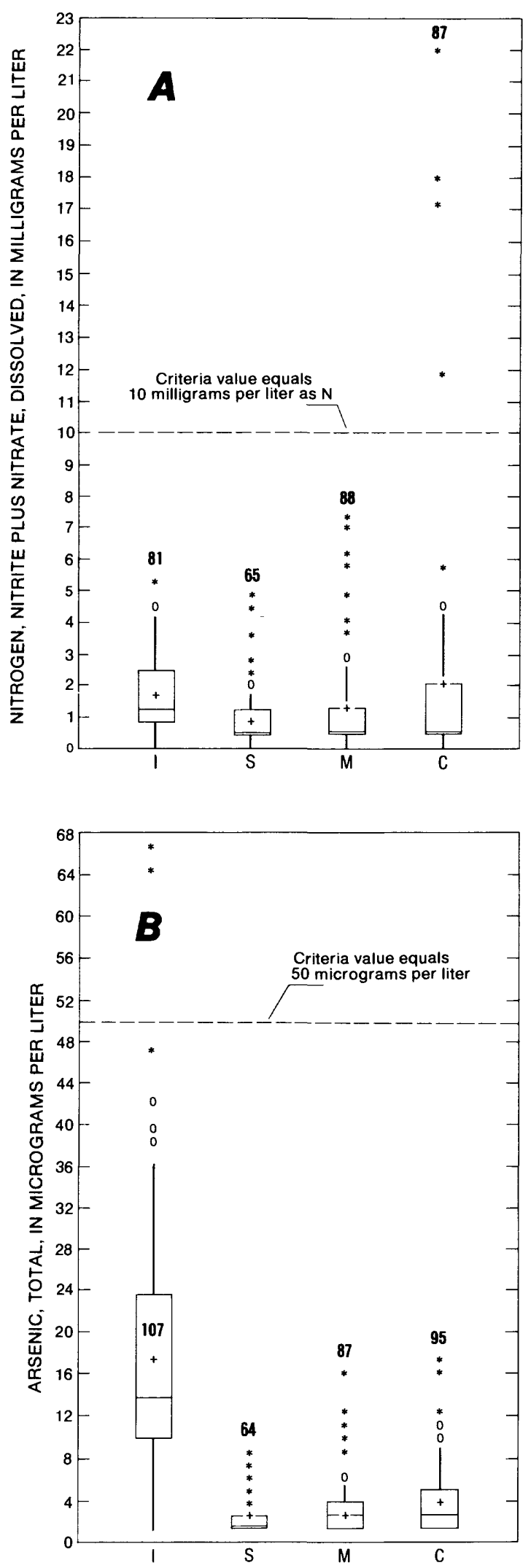

Agriculture in Fresno to investigate the effects of stormwater runoff and its constituents on the ground-water supply and local soils.

\section{EXPLANATION}

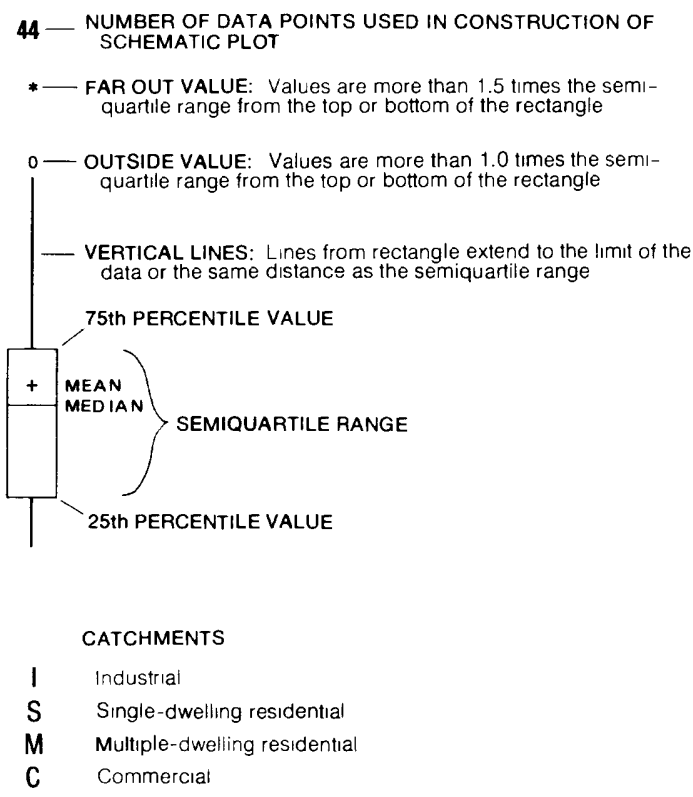

Figure 29. Comparison of runoff quality data and criteria values for constituents that have primary drinking water standards. $A$, Dissolved nitrogen (nitrite plus nitrate). $B$, Total arsenic. $C$, Total recoverable cadmium. $D$, Total recoverable chromium. $E$, Total recoverable lead. $F$, Total recoverable lindane. $G$, Total recoverable mercury. $H$, Total recoverable methoxychlor. I, Total recoverable silvex. I, Total recoverable 2,4-D. 
Rainfall and runoff quantity and quality from an industrial, single-dwelling residential, multiple-dwelling residential, and commercial land-use catchment were monitored during the 1981-82 and 1982-83 rain seasons. Discrete runoff samples were collected throughout storms in addition to storm composite rainfall samples, and were analyzed for
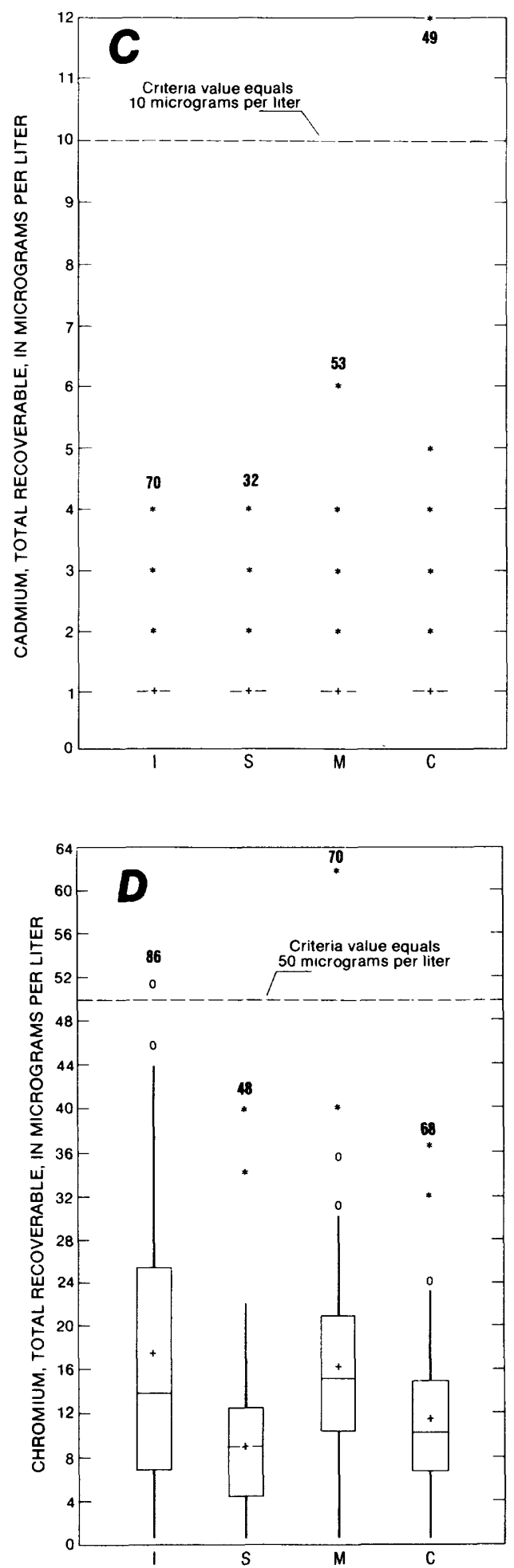

numerous physical, inorganic, organic, and biological constituents. Atmospheric dry-deposition and street-surface particulate samples were collected and analyzed.

Storm characteristics data were calculated and compiled for the two rain seasons. Rainfall total, number of dry hours since last storm, and maximum 20-minute rainfall intensity
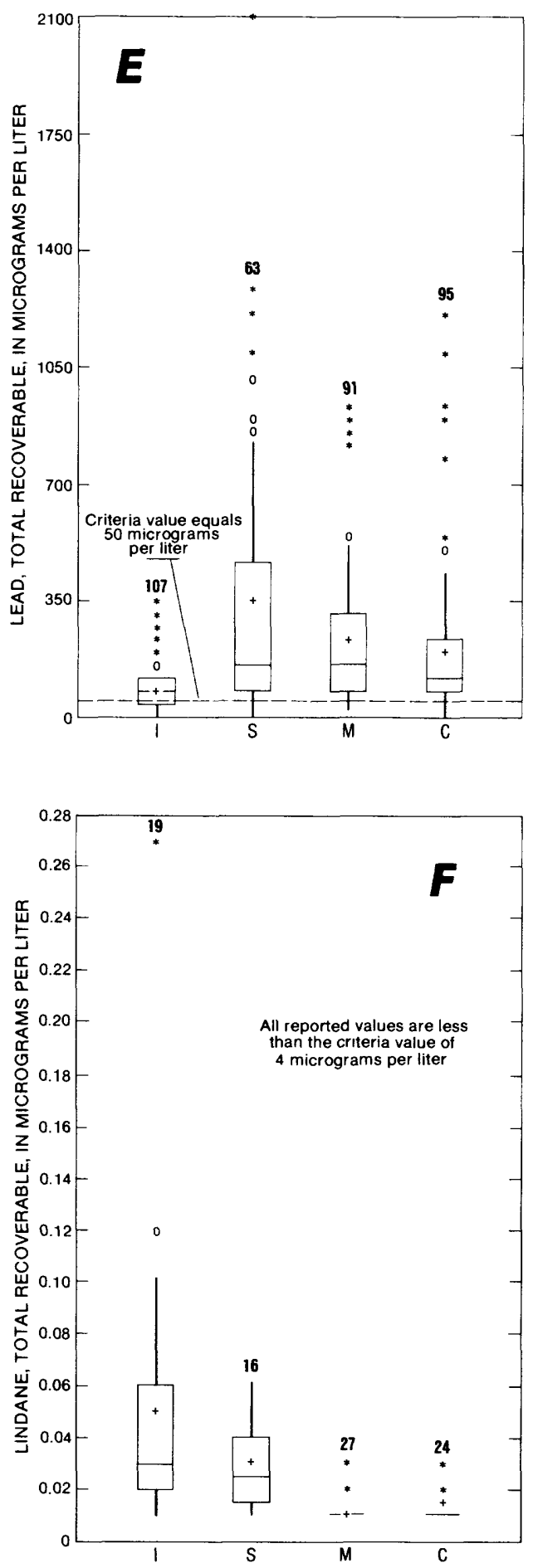

Figure 29. Continued. 
were used as independent variables to develop rainfall-runoff multiple regression equations for all four catchments. Rainfall total was the only statistically significant independent variable at the 0.05 -significance level for the commercial catchment. All three variables were significant for the multiple-dwelling residential catchment. Rainfall total and number of dry hours since last storm were the only significant variables for the single-dwelling residential and industrial catchments.
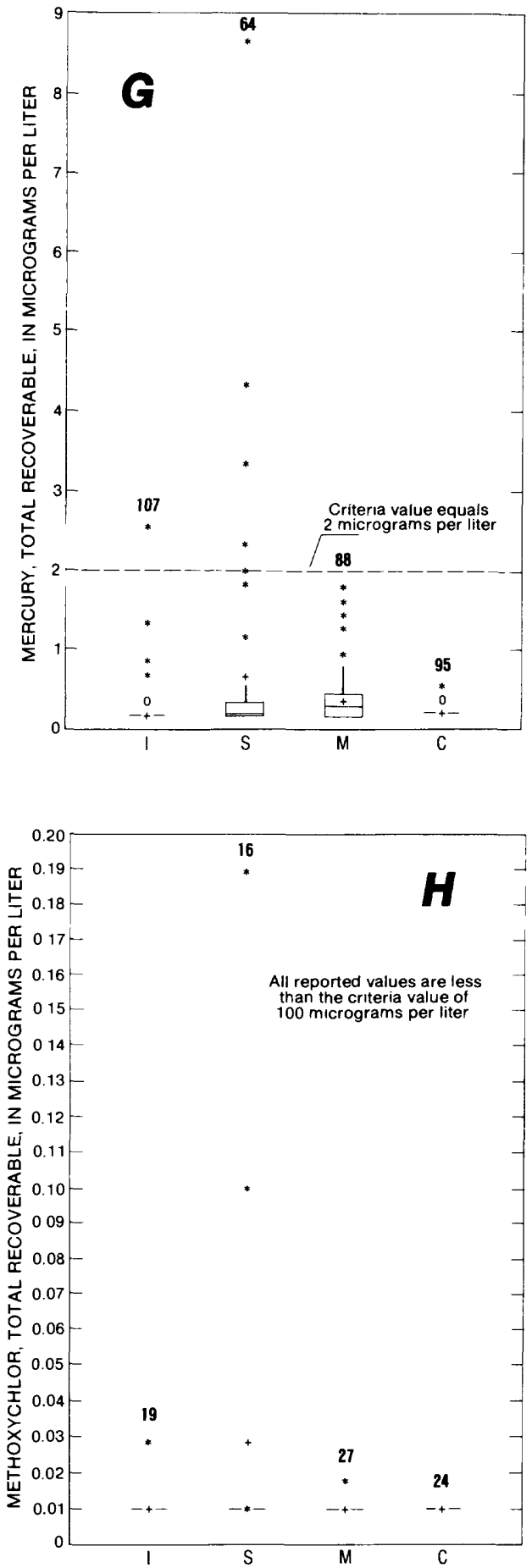

Figure 29. Continued.
Results of nonparametric statistical comparison testing showed there was no statistical difference at the 0.05 significance level for rainfall constituent concentrations between rain seasons at the single-dwelling residential site. At the industrial site, only dissolved phosphorus and dissolved organic carbon were statistically different between rain seasons. Results of comparison testing among rainfall sites showed significantly higher concentrations of ammonia plus organic nitrogen, ammonia, $\mathrm{pH}$, and phenols in rain-
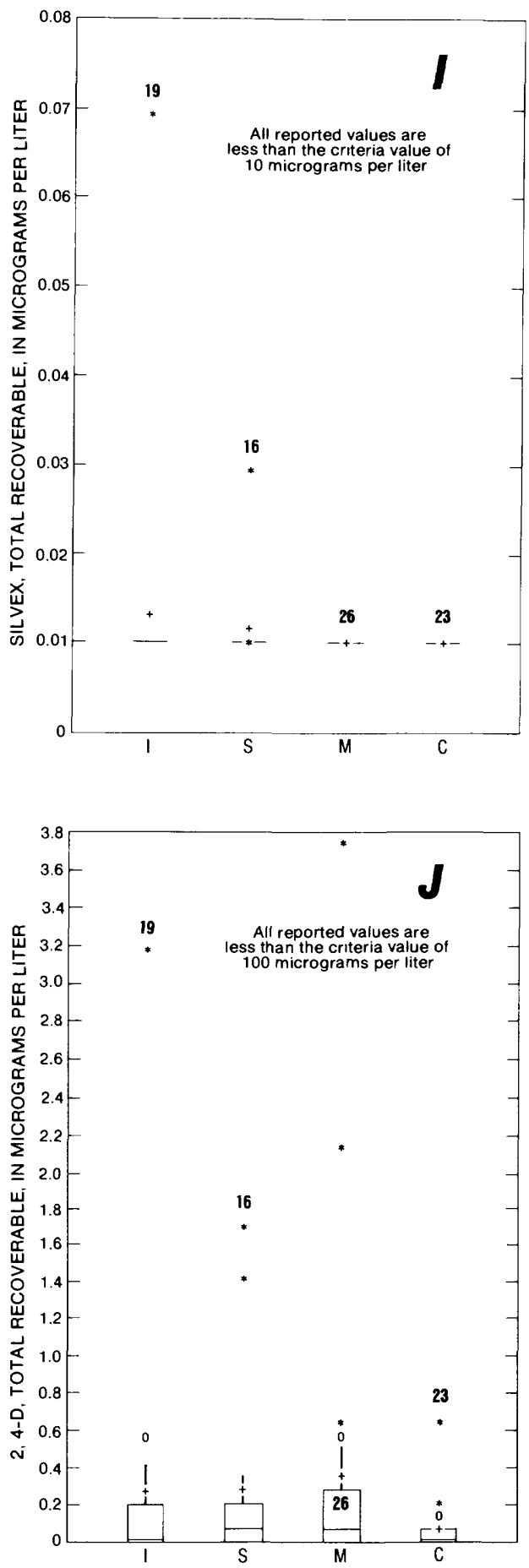

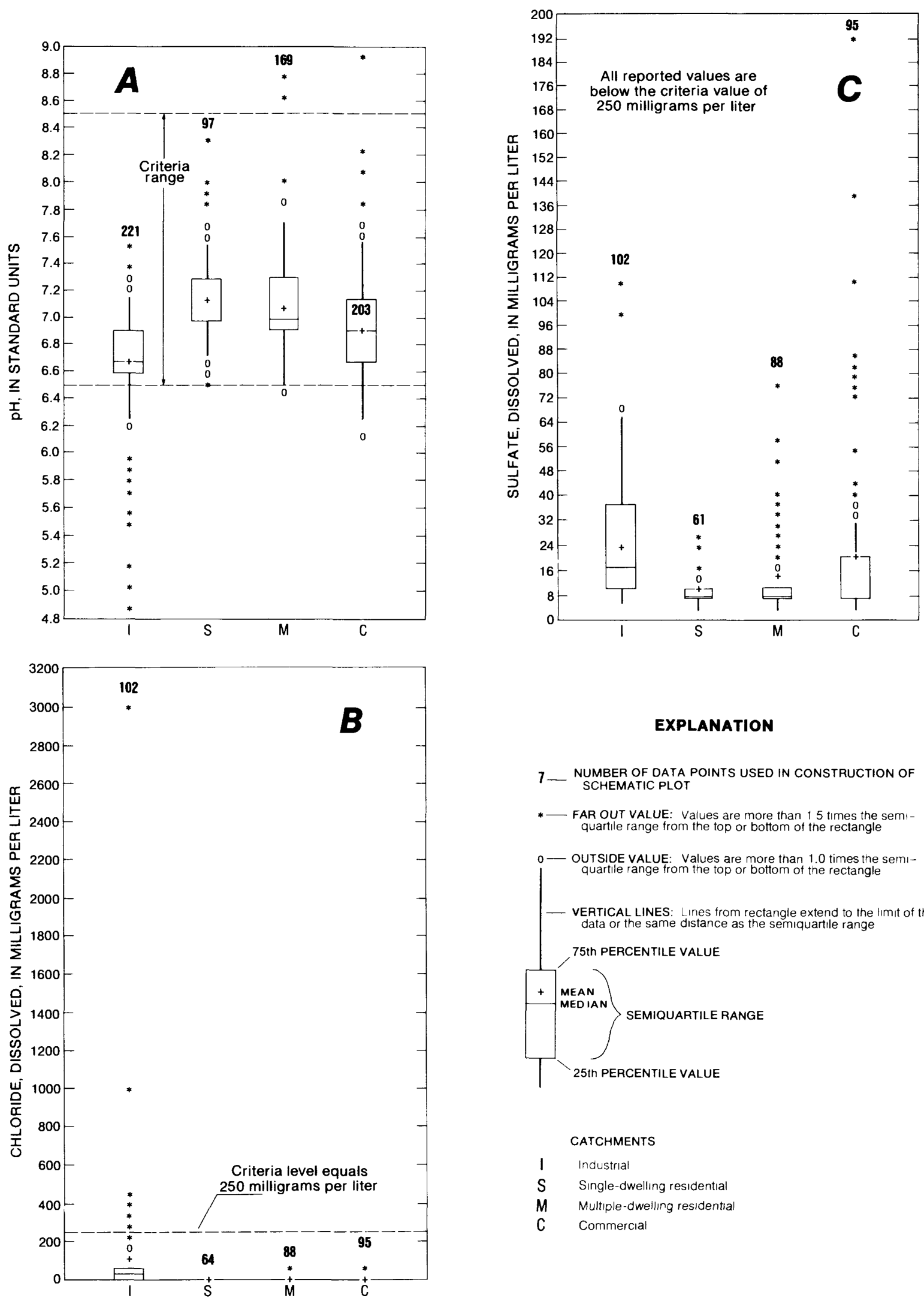

EXPLANATION

7 - NUMBER OF DATA POINTS USEO IN CONSTRUCTION OF SCHEMATIC PLOT

* - Far out VAlue: Values are more than 15 times the semiquartile range from the top or bottom of the rectangle

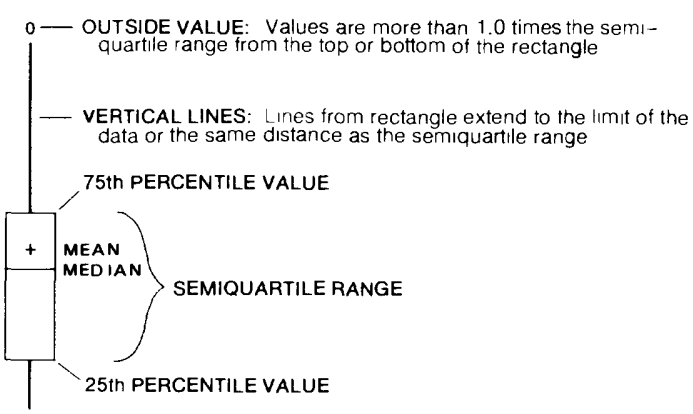

CATCHMENTS

I Industriat

S Single-dwelling residential

M Multiple-dwelıng resıdential

C Commercial

Figure 30. Comparison of runoff quality data and criteria values for constituents that have secondary drinking water standards. $A, \mathrm{pH}$. $B$, Dissolved chloride. $C$, Dissolved sulfate. $D$, Total recoverable copper. $E$, Total recoverable iron. $F$, Total recoverable manganese. $G$, Total recoverable zinc. 

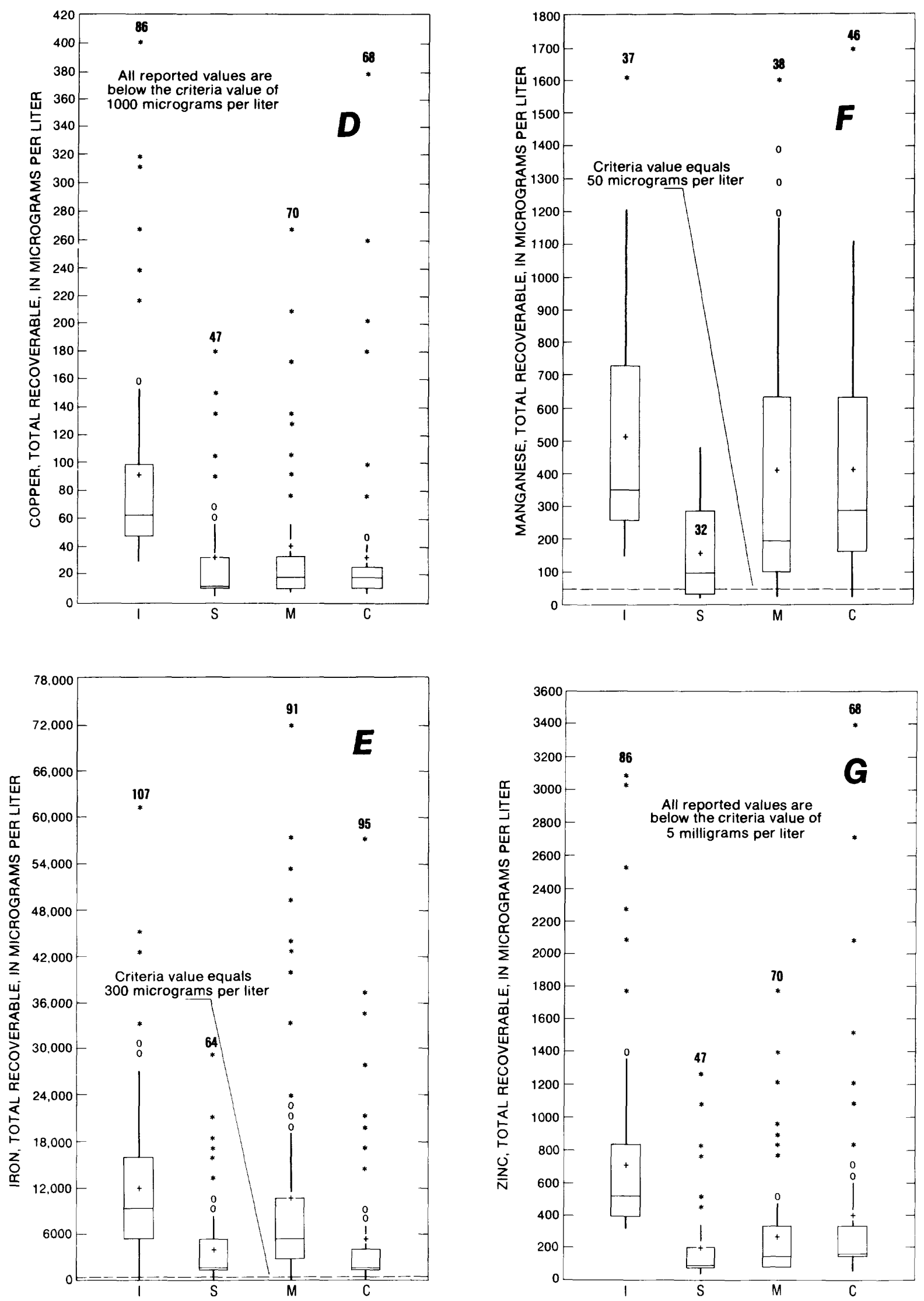

Figure 30. Continued. 
fall at the industrial site than for the two residential sites.

The highest runoff concentrations for most constituents from the residential and commercial catchments occurred during the initial storm runoff and then decreased throughout the remainder of the storm, independent of hydraulic conditions. Metal concentrations generally were higher during initial runoff, but also increased as flow increased. Most runoff constituent concentrations from the industrial catchment fluctuated greatly during storms; numerous unexplained concentration spikes were monitored.

Results of nonparametric statistical comparison testing of runoff constituent data showed significantly higher concentrations for the industrial catchment compared to the residential and commercial catchments for almost all 62 monitored nonpesticide constituents. Of the 62 monitored constituents, only 10 were determined to have comparable concentrations between the industrial catchment and at least one of the other three catchments. Total recoverable lead was one of the very few constituents that had lower concentrations for the industrial catchment compared to the other three catchments. Sodium and $\mathrm{pH}$ were the only constituents that had significantly different concentrations for all four catchments. For the two residential catchments, 50 of the 57 monitored constituents were determined to have statistically equivalent runoff concentrations. Of the 12 constituents determined to be significantly different, the higher suspended sediment, iron, aluminum, and manganese concentrations for the multiple-dwelling residential catchment probably are the result of soil erosion from undeveloped land areas and, therefore, are not really representative of urban runoff. The commercial catchment runoff concentrations for most constituents generally were similar to concentrations for the residential catchments.

Numerous constituent concentration relations were developed for all but the industrial catchment using linear regression analysis. The most noteworthy relations were those between specific conductance and dissolved organic nitrogen plus ammonia, dissolved nitrite plus nitrate, and dissolved phosphorus. The lowest "percentage of variation explained" for these nine relations was 86 percent. These equations were used to estimate concentrations that were then used to compute storm constituent loads.

Constituent event mean concentrations (EMC's) were calculated from computed storm-runoff loads. The EMC for most constituents for all but the industrial catchment were highest for the first two or three storms of the year after which they became quasi-constant for the remainder of the rain season. The industrial constituent EMC's generally did not show any pattern.

EMC multiple regression predictor equations were developed for some constituents using number of dry hours since last storm, runoff volume, and number of days since first storm of rain season as independent variables. Number of dry hours since last storm and runoff volume were the predominant independent variables, which indicates that material accumulates on the catchment with time between storms, and that the EMC is dependent upon the volume of runoff that washes off and dilutes the accumulated material.

Average annual constituent unit loads were computed for 18 constituents for each catchment using the average Fresno annual rainfall total, the average rainfall-runoff coefficient for each catchment, and the average constituent EMC's for each catchment. Although most constituent concentrations for the industrial catchment are substantially higher compared to the commercial catchment, the unit loads for the two catchments are similar because of the large difference in catchment runoff volume. Phosphorus is the only constituent that has a unit load for one catchment that is substantially different from the other three catchments; the industrial catchment unit load is about 10 times higher than that for the other catchments.

Forty to fifty percent of the nitrogen runoff loads for the two residential catchments were attributed to the rainfall load. In the case of phosphorus, 10 percent or less of the runoff load was attributable to rainfall. These percentages are considerably less for the industrial catchment because of the larger runoff nutrient loads for the industrial catchment compared to the residential catchments. The same can be said for other constituents, except for lead which is one of the very few constituents that had lower runoff concentrations for the industrial catchment compared to the residential catchments. Rainfall metal load percentages generally were smaller than for nutrients.

The difference between the rainfall load and the runoff load represents the load attributable to catchment washoff. Some of the sources that contribute to this washoff load consist of atmospheric dry deposition, vehicular deposition, animal waste, fertilizers, and overland flow erosion material. Because of the uncertainty of collecting atmospheric drydeposition and street-surface particulate data, the samples collected of these types of data were not used to compute catchment loads for use in catchment pollutant budget analysis.

The conventional use of mass-concentration units for the reporting of atmospheric dry-deposition and street-surface particulate constituent concentrations can be misleading. Time-series plots of dry-deposition constituent concentrations show a cyclic pattern throughout the year. However, timeseries plots of total dry-mass deposition rate also are cyclic, but totally out of phase from the concentration plots. This indicates that dry-deposition mass-concentration data are significantly affected by the bulk dry-mass deposition rate.

The street-surface particulate mass-concentration data for some of the metal and organic constituents for the commercial catchment are considerably higher than for the other three catchments. These higher concentrations are due to the removal of the large gravel-size material by a daily commercial sweeping service and are not indicative of larger amounts of these constituents on the surface of the commercial catchment compared to the other three catchments. The 
sweeper is unable to remove all the fine-grained material, which has a greater percentage of particulate surface area per volume of material compared to the coarse-grained material. Metal and organic constituents tend to adsorb to the surface of fine-grained particulate material, thus resulting in higher mass concentrations.

The organophosphorus compounds, parathion, diazinon, and malathion were the most prevalent pesticides detected in rainfall. Other detected pesticides in rainfall included chlordane, lindane, methoxychlor, endosulfan, and 2,4-D. Of these, only methoxychlor and endosulfan were not consistently detected in the runoff. Chlordane occurred more frequently in runoff than in rainfall. In addition, pesticides detected in atmospheric dry-deposition and street-surface particulate samples were detected in rainfall and runoff.

\section{SELECTED REFERENCES}

Bevenue, A., Ogata, J.N., and Hylin, J.W., 1972, Organochlorine pesticides in rainwater, Oahu, Hawaii, 1971-1972: Bulletin of Environmental Contamination and Toxicology, v. 8, no. 4, p. 238-241.

Doyle, W.H., Jr., and Lorens, J.A., 1982, Data management system for urban hydrology studies program: U.S. Geological Survey Open-File Report 82-442, 272 p.

Eisenreich, W.J., Looney, B.B., and Thornton, J.D., 1981, Airborne organic contaminants in the Great Lakes ecosystem: Environmental Science and Technology, v. 15, no. 1, p. 30-38.
Gibbs, R.J., 1977, Transport phases of transition metals in the Amazon and Yukon Rivers: Geological Society of America Bulletin, v. 88, p. 829-843.

Helwig, J.T., and Council, K.A., eds., 1979, SAS user's guide: SAS Institute, Inc., Raleigh, North Carolina, 494 p.

Hem, J.D., 1970, Study and interpretation of the chemical characteristics of natural water: U.S. Geological Survey WaterSupply Paper 1473, 363 p.

National Oceanic and Atmospheric Administration, 1981, Climatological data, annual summary, California, 1981: v. 85, no. 13.

Oltmann, R.N., Guay, J.R., and Shay, J.M., 1987, Rainfall and runoff quantity and quality data collected at four urban landuse catchments in Fresno, California: October 1981 to April 1983: U.S. Geological Survey Open-File Report 84-718, 139 p.

Strachan, W.M.J., and Huneault, H., 1979, Polychlorinated biphenyls and organochlorine pesticides in Great Lakes precipitation: Journal of Great Lakes Research, v. 5, no. 1, p. 61-68.

U.S. Environmental Protection Agency, 1977, National interim primary drinking water regulations: U.S. Environmental Protection Agency, Office of Water Supply, EPA 570/9-76-003, $159 \mathrm{p}$.

1979, National secondary drinking water regulations: Federal Register, v. 44 , no. 140 , July 19, 1979, p. 4219542202.

Wershaw, R.L., Fishman, M.F., Grabbe, R.R., and Lowe, L.E., 1983, Methods for the determination of organic substances in water and fluvial sediments: U.S. Geological Survey Techniques of Water-Resources Investigations, Book 5, Chapter A3, $173 \mathrm{p}$. 

TABLES 1-35 
Table 1. Characteristics of the four monitored urban-runoff catchments

[., no data available]

\begin{tabular}{|c|c|c|c|c|}
\hline \multirow[b]{2}{*}{ Catchment characteristic } & \multicolumn{4}{|c|}{ Catchment } \\
\hline & Industrial & $\begin{array}{c}\text { Single- } \\
\text { dwelling } \\
\text { residential }\end{array}$ & $\begin{array}{l}\text { Multiple- } \\
\text { dwelling } \\
\text { residential }\end{array}$ & Commercial \\
\hline \multicolumn{5}{|l|}{ Contributing drainage area } \\
\hline (acres)--- & 278 & 94.0 & 46.1 & 61.8 \\
\hline \multicolumn{5}{|l|}{ Impervious area (percentage of } \\
\hline drainage area)-- & 52.5 & 43.4 & 57.0 & 98.9 \\
\hline Average basin slope $(\mathrm{ft} / \mathrm{mi})-$ & 8.00 & 7.90 & 7.03 & 13.8 \\
\hline Main conveyance slope (ft/mi)----- & 8.00 & 28.6 & 9.96 & 5.70 \\
\hline \multicolumn{5}{|l|}{ Permeability of a horizon of } \\
\hline soil profile (inches/hour) - & 2.70 & 3.75 & 7.50 & . \\
\hline \multicolumn{5}{|l|}{ Soil-water capacity (inch of } \\
\hline water/inch of soil) - & 0.12 & 0.12 & 0.07 & - \\
\hline Soil-water $\mathrm{pH}$ of the A horizon----- & 6.7 & 6.7 & 6.7 & • \\
\hline \multirow{2}{*}{\multicolumn{5}{|c|}{ Hydrologic soil group, SCS }} \\
\hline & B & B & A & - \\
\hline Population density (person $/ \mathrm{mi}^{2}$ ) - - & 0 & 7,700 & 16,400 & 0 \\
\hline \multicolumn{5}{|l|}{$\begin{array}{l}\text { Land use, percentage of drainage } \\
\text { area: }\end{array}$} \\
\hline Low-density residential-- & 0 & 9.0 & 0 & 0 \\
\hline Medium-density residential-_---- & 0 & 87.3 & 0 & 0 \\
\hline High-density residential-- & 0 & 0 & 87.0 & 0 \\
\hline Commercial-_- & 0 & 0 & 0 & 100.0 \\
\hline Industrial---_- & 65.8 & 0 & 0 & 0 \\
\hline Idle or vacant-- & 34.2 & 3.7 & 13.0 & 0 \\
\hline \multicolumn{5}{|l|}{$\begin{array}{l}\text { Detention storage, within catch- } \\
\text { ment associated with storage }\end{array}$} \\
\hline facilities (acre-feet of storage) & 0 & 0 & 0 & 0 \\
\hline \multicolumn{5}{|l|}{ Percentage of area drained by } \\
\hline storm-sewer system- & 100.0 & 100.0 & 100.0 & 100.0 \\
\hline \multicolumn{5}{|l|}{ Percentage of streets with curb } \\
\hline and gutter drainage- & 47.0 & 100.0 & 96.3 & 100.0 \\
\hline \multirow{2}{*}{$\begin{array}{l}\text { Percentage of streets with ditch } \\
\text { and swale drainage- }\end{array}$} & & & & \\
\hline & 53.0 & 0 & 3.7 & 0 \\
\hline
\end{tabular}

${ }^{1}$ Soil Conservation Service (SCS) designations: A, soils having a high infiltration rate; $B$, soils having a moderate infiltration rate. 
Table 2. Quality constituents analyzed for in rainfall, runoff, atmospheric dry-deposition, and street-surface particulate samples

[Type of sample: $x$, analyzed for during both rain seasons; 1, analyzed for during 1981-82 rain season only; 2, analyzed for during 1982-83 rain season only; 3, analyzed for September 3, 1982; ., no data available. Atmospheric dry deposition: Material was washed from a collection bucket with deionized water and then analyzed as a water sample. Street-surface particulate: All constituents are total recoverable from dry samples. Atmospheric dry-deposition and street-surface particulate samples are reported in mass concentration units]

\begin{tabular}{|c|c|c|c|c|c|}
\hline \multirow[b]{2}{*}{ Property or constituent } & \multicolumn{5}{|c|}{ Type of sample } \\
\hline & Rainfall & Runoff & $\begin{array}{c}\text { Atmospheric } \\
\text { dry } \\
\text { deposition }\end{array}$ & $\begin{array}{c}\text { Street- } \\
\text { surface } \\
\text { particulate }\end{array}$ & $\begin{array}{l}\text { Dry- } \\
\text { weather } \\
\text { runoff }\end{array}$ \\
\hline \multicolumn{6}{|l|}{ INORGANICS } \\
\hline Specific conductance & $\mathbf{x}$ & $\mathbf{x}$ & - & . & 3 \\
\hline $\mathrm{pH}-\cdots-m_{1}$ & $\mathrm{x}$ & $\mathrm{x}$ & • & . & 3 \\
\hline \multicolumn{6}{|l|}{ Major ions } \\
\hline *Hardness, total (as $\mathrm{CaCO}_{3}$ ) & • & $\mathbf{x}$ & . & . & 3 \\
\hline Calcium, dissolved- & $\mathbf{x}$ & $\mathbf{x}$ & $\mathbf{x}$ & $\mathbf{x}$ & 3 \\
\hline Magnesium, dissolved & $\mathbf{x}$ & $\mathbf{x}$ & $\mathbf{x}$ & $\mathbf{x}$ & 3 \\
\hline Sodium, díssolved & $\mathbf{x}$ & $\mathbf{x}$ & $\mathbf{x}$ & $\mathbf{x}$ & 3 \\
\hline Potassium, dissolved & $\mathbf{x}$ & $\mathbf{x}$ & $\mathbf{x}$ & $\mathbf{x}$ & 3 \\
\hline Alkalinity, total (as $\left.\mathrm{CaCO}_{3}\right)$ & $\mathbf{x}$ & $\mathbf{x}$ & . & . & 3 \\
\hline Sulfate, dissolved & $\mathbf{x}$ & $\mathbf{x}$ & $\mathbf{x}$ & . & 3 \\
\hline Chloride, dissolved & $\mathbf{x}$ & $\mathbf{x}$ & $\mathbf{x}$ & - & 3 \\
\hline Silica, dissolved & $\mathbf{x}$ & $\mathbf{x}$ & $\mathbf{x}$ & . & 3 \\
\hline \multicolumn{6}{|l|}{ Nutrients } \\
\hline Nitrogen, nitrate, dissolved (as $\mathrm{N}$ ) & . & 1 & • & - & - \\
\hline Nitrogen, nitrite, dissolved (as N) & $\mathrm{x}$ & . & . & $\mathrm{x}$ & . \\
\hline Nitrogen, nitrite plus nitrate, & & & & & \\
\hline dissolved (as $\mathrm{N}$ ) & $\mathbf{x}$ & $\mathbf{x}$ & $\mathbf{x}$ & $\mathbf{x}$ & 3 \\
\hline Nitrogen, ammonia, total (as $\mathrm{N}$ ) & . & - & $\mathbf{x}$ & $\mathbf{x}$ & . \\
\hline Nitrogen, ammonia, dissolved (as $\mathrm{N}$ ) & $\mathbf{x}$ & $\mathbf{x}$ & - & - & 3 \\
\hline Nitrogen, ammonia plus organic, total (as N) & - & $\mathbf{x}$ & $\mathbf{x}$ & $\mathbf{x}$ & 3 \\
\hline Nitrogen, ammonia plus organic, & 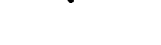 & & 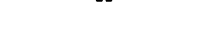 & & \\
\hline dissolved (as $\mathrm{N}$ ) & $\mathbf{x}$ & $\mathbf{x}$ & . & . & 3 \\
\hline *Nitrogen, organic, total (as $\mathrm{N}$ ) & - & - & $\mathbf{x}$ & - & - \\
\hline *Nitrogen, organic, dissolved (as N) & $\mathbf{x}$ & $\mathbf{x}$ & - & - & 3 \\
\hline Nitrogen, total (as $\mathrm{N}$ ) & - & - & - & $\mathbf{x}$ & - \\
\hline *Nitrogen, dissolved (as $\mathrm{N}$ ) & $\mathbf{x}$ & $\mathbf{x}$ & . & . & 3 \\
\hline Phosphorus, total (as P) & . & $\mathbf{x}$ & $\mathrm{x}$ & $\mathrm{x}$ & 3 \\
\hline Phosphorus, dissolved (as P) & $\mathbf{x}$ & $\mathbf{x}$ & . & . & 3 \\
\hline Phosphorus, orthophosphate, total (as P) & . & $\mathrm{x}$ & $\mathrm{x}$ & . & 3 \\
\hline Phosphorus, orthophosphate, dissolved (as P) & $\mathbf{x}$ & $\mathbf{x}$ & - & - & 3 \\
\hline \multicolumn{6}{|l|}{ Metals } \\
\hline Aluminum, total recoverable and dissolved........... & 2 & 2 & 2 & 2 & - \\
\hline Arsenic, total- & 2 & $\mathrm{x}$ & 2 & $\mathbf{x}$ & 3 \\
\hline Arsenic, dissolved & . & $\mathbf{x}$ & . & . & 3 \\
\hline Cadmium, total recoverable and dissolved & . & 1 & . & 1 & 3 \\
\hline Chromium, total recoverable & 2 & $\mathbf{x}$ & 2 & 1 & 3 \\
\hline Chromium, dissolved & . & $\mathbf{x}$ & . & . & 3 \\
\hline Copper, total recoverable and dissolved & 2 & $\mathrm{x}$ & 2 & $\mathbf{x}$ & 3 \\
\hline Iron, total recoverable and dissolved & 2 & $\mathbf{x}$ & 2 & $\mathbf{x}$ & 3 \\
\hline Lead, total recoverable and dissolved & $\mathbf{x}$ & $\mathrm{x}$ & $\mathrm{x}$ & $\mathrm{x}$ & 3 \\
\hline Manganese, total recoverable and dissolved-..... & 2 & 2 & 2 & 2 & . \\
\hline Mercury, total recoverable & 2 & $\mathbf{x}$ & 2 & $\mathbf{x}$ & 3 \\
\hline Mercury, dissolved & . & $\mathbf{x}$ & . & . & 3 \\
\hline Nickel, total recoverable and dissolved & 2 & $\mathbf{x}$ & 2 & $\mathrm{x}$ & 3 \\
\hline Zinc, total recoverable and dissolved & 2 & $\mathrm{x}$ & 2 & $\mathbf{x}$ & 3 \\
\hline BIOLOGICAL & & & & & \\
\hline Coliform, fecal, 0.7 um-MF & - & $\mathbf{x}$ & - & - & 3 \\
\hline OXYGEN DEMAND & & & & & \\
\hline Oxygen demand, chemical, $0.25 \mathrm{~N}$ dichromate-... & $\mathbf{x}$ & $\mathbf{x}$ & . & $\mathbf{x}$ & 3 \\
\hline
\end{tabular}


Table 2. Quality constituents analyzed for in rainfall, runoff, atmospheric dry-deposition, and street-surface particulate samplesContinued

\begin{tabular}{|c|c|c|c|c|c|}
\hline Property or constituent & Rainfall & Runoff & $\begin{array}{c}\text { Type of samp } \\
\text { Atmospheric } \\
\text { dry } \\
\text { deposition }\end{array}$ & $\begin{array}{l}\text { le } \\
\begin{array}{l}\text { Street- } \\
\text { surface }\end{array} \\
\text { particulate }\end{array}$ & $\begin{array}{l}\text { Dry- } \\
\text { weather } \\
\text { runoff }\end{array}$ \\
\hline \multicolumn{6}{|l|}{$\begin{array}{l}\text { OXYGEN DEMAND--Continued } \\
\text { Oxygen demand, biochemical, carbonaceous, }\end{array}$} \\
\hline $\begin{array}{l}5 \text {-day at } 20^{\circ} \mathrm{C} \\
\text { Oxygen demand, biochemical, carbonaceous, }\end{array}$ & • & $\mathbf{x}$ & • & - & • \\
\hline 20 day $-\cdots$ & - & $\mathrm{x}$ & - & - & - \\
\hline \multicolumn{6}{|l|}{ PHYSICAL PROPERTIES } \\
\hline Turbidity, NTU- & . & $\mathrm{x}$ & . & . & 3 \\
\hline 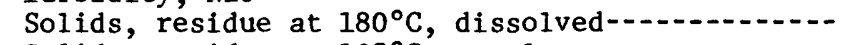 & . & $\mathrm{x}$ & - & - & 3 \\
\hline Solids, residue at $105^{\circ} \mathrm{C}$, total- & - & . & $\mathrm{x}$ & $\mathbf{x}$ & - \\
\hline *Solids, sum of constituents, dissolved-...... & - & $\mathrm{x}$ & $\mathrm{x}$ & - & 3 \\
\hline Sediment, suspended & - & $\mathrm{x}$ & - & - & 3 \\
\hline \multicolumn{6}{|l|}{ ORGANICS } \\
\hline Carbon, organic, dissolved & $\mathrm{x}$ & $\mathrm{x}$ & $\mathbf{x}$ & • & 3 \\
\hline Carbon, organic, suspended & . & $\mathrm{x}$ & . & . & . \\
\hline Carbon, inorganic plus organic, total-n.- & - & . & - & $\mathbf{x}$ & . \\
\hline Carbon, inorganic, total- & . & - & - & $\mathbf{x}$ & . \\
\hline Cyanide, total and dissolved- & - & 2 & - & - & - \\
\hline Oil and grease, total recoverable, gravimetric--- & $\dot{0}$ & $\mathrm{x}$ & - & - & - \\
\hline Phenols, total recoverable & 2 & 2 & - & - & - \\
\hline Polychlorinated biphenyls, total recoverable-...- & $\mathbf{x}$ & $\mathrm{x}$ & 2 & $\mathbf{x}$ & 3 \\
\hline Polychlorinated naphthalenes, total recoverable-- & $\mathbf{x}$ & $\mathrm{x}$ & 2 & $\mathbf{x}$ & 3 \\
\hline Dibromochloropropane, total recoverable & - & 1 & - & - & - \\
\hline \multicolumn{6}{|l|}{ Volatile organics } \\
\hline Benzene, total recoverable- & • & 2 & • & • & • \\
\hline 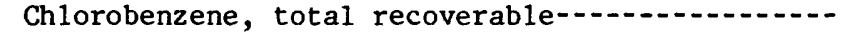 & . & 2 & • & . & . \\
\hline Ethylbenzene, total recoverable & - & 2 & - & - & - \\
\hline \multicolumn{6}{|l|}{ Organochlorine compounds } \\
\hline Aldrin, total recoverable & $\mathbf{x}$ & $\mathbf{x}$ & 2 & $\mathrm{x}$ & 3 \\
\hline Chlordane, total recoverable & $\mathbf{x}$ & $\mathbf{x}$ & 2 & $\mathbf{x}$ & 3 \\
\hline DDD, total recoverable & $\mathbf{x}$ & $\mathbf{x}$ & 2 & $\mathbf{x}$ & 3 \\
\hline $\mathrm{DDE}$, total recoverable- & $\mathbf{x}$ & $\mathbf{x}$ & 2 & $\mathbf{x}$ & 3 \\
\hline DDT, total recoverable & $\mathbf{x}$ & $\mathbf{x}$ & 2 & $\mathbf{x}$ & 3 \\
\hline Dieldrin, total recoverable & $\mathrm{x}$ & $\mathrm{x}$ & 2 & $\mathbf{x}$ & 3 \\
\hline Endosulfan, total recoverable & $\mathbf{x}$ & $\mathrm{x}$ & 2 & $\mathbf{x}$ & 3 \\
\hline Endrin, total recoverable- & $\mathbf{x}$ & $\mathbf{x}$ & 2 & $\mathbf{x}$ & 3 \\
\hline Heptachlor, total recoverable & $\mathbf{x}$ & $\mathbf{x}$ & 2 & $\mathbf{x}$ & 3 \\
\hline Heptachlor epoxide, total recoverable-..... & $\mathbf{x}$ & $\mathbf{x}$ & 2 & $\mathbf{x}$ & 3 \\
\hline Lindane, total recoverable & $\mathbf{x}$ & $\mathbf{x}$ & 2 & $\mathbf{x}$ & 3 \\
\hline 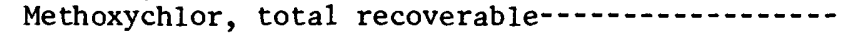 & $\mathbf{x}$ & $\mathbf{x}$ & 2 & $\mathbf{x}$ & 3 \\
\hline Mirex, total recoverable & $\mathbf{x}$ & $\mathbf{x}$ & 2 & $\mathbf{x}$ & 3 \\
\hline Perthane, total recoverable & $\mathbf{x}$ & $\mathbf{x}$ & 2 & $\mathbf{x}$ & 3 \\
\hline Toxaphene, total recoverable & $\mathbf{x}$ & $\mathrm{x}$ & 2 & $\mathbf{x}$ & 3 \\
\hline \multicolumn{6}{|l|}{ Organophosphorus compounds } \\
\hline Diazinon, total recoverable- & $\mathbf{x}$ & $\mathrm{x}$ & 2 & $\mathbf{x}$ & 3 \\
\hline Ethion, total recoverable & $\mathbf{x}$ & $\mathbf{x}$ & 2 & $\mathbf{x}$ & 3 \\
\hline Malathion, total recoverable-co & $\mathbf{x}$ & $\mathrm{x}$ & 2 & $\mathbf{x}$ & 3 \\
\hline Methyl parathion, total recoverable- & $\mathbf{x}$ & $\mathbf{x}$ & 2 & $\mathbf{x}$ & 3 \\
\hline Methyl trithion, total recoverable & $\mathbf{x}$ & $\mathbf{x}$ & 2 & $\mathbf{x}$ & 3 \\
\hline Parathion, totaí recoverable & $\mathrm{x}$ & $\mathbf{x}$ & 2 & $\mathbf{x}$ & 3 \\
\hline Trithion, total recoverable-c. & $\mathrm{x}$ & $\mathrm{x}$ & 2 & $x$ & 3 \\
\hline \multicolumn{6}{|l|}{ Carbamate insecticides } \\
\hline 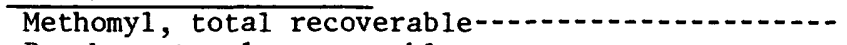 & 1 & 1 & - & . & • \\
\hline Propham, total recoverable & 1 & $\overline{1}$ & . & . & . \\
\hline Sevin, total recoverable- & $\overline{1}$ & 1 & . & . & . \\
\hline \multicolumn{6}{|l|}{ Chlorophenoxy acid herbicides } \\
\hline Silvex, total recoverable-- & $\mathbf{x}$ & $\mathbf{x}$ & 2 & . & 3 \\
\hline $2,4-\mathrm{D}$, total recoverable-n & $\mathrm{x}$ & $\mathrm{x}$ & 2 & $\mathbf{x}$ & 3 \\
\hline $2,4-D P$, total recoverable & $\mathbf{x}$ & $\mathbf{x}$ & 2 & . & 3 \\
\hline $2,4,5-\mathrm{T}$, total recoverable & $\mathbf{x}$ & $\mathrm{x}$ & 2 & - & 3 \\
\hline
\end{tabular}


Table 3. Average monthly rainfall totals for Fresno, California, compared to study period monthly rainfall totals

[National Weather Service data collected at Fresno Air Terminal]

\begin{tabular}{|c|c|c|c|c|c|c|c|c|c|}
\hline \multirow[t]{2}{*}{$\begin{array}{c}\text { Rainfall } \\
\text { record }\end{array}$} & \multicolumn{9}{|c|}{ Monthly rainfall totals, in inches } \\
\hline & Sept & Oct & Nov & Dec & Jan & $\mathrm{Feb}$ & Mar & Apr & $\begin{array}{c}\text { 8-month } \\
\text { total }\end{array}$ \\
\hline \multirow{3}{*}{$\begin{array}{l}\text { 104-year } \\
\text { average }\end{array}$} & \multicolumn{9}{|c|}{ Fresno Air Terminal } \\
\hline & 0.07 & 0.42 & 1.22 & 1.71 & 1.84 & 1.72 & 1.62 & 1.24 & 9.84 \\
\hline & \multicolumn{9}{|c|}{ Study period } \\
\hline $1981-82$ & 0.00 & 0.58 & 1.22 & 0.65 & 2.11 & 0.58 & 4.76 & 0.89 & 10.79 \\
\hline $1982-83$ & 1.10 & 1.58 & 3.16 & 1.59 & 5.14 & 3.70 & 4.53 & 2.76 & 23.56 \\
\hline
\end{tabular}


Table 4. Storm characteristics for storms monitored at four catchments

[Abbreviations: in., inch; $\mathrm{ft}^{3} / \mathrm{s}$, cubic foot per second; min, minute; $\mathrm{h}$, hour; d, day; ., no data available]

Total runoff volume: Runoff volume not computed for some small storms; depth in inches covering the catchment drainage area.

Rainfall-runoff coefficient: Coefficient range 0 to 1; see page 17 for discussion of coefficients that are greater than 1 .

Peak flow: If value is not shown, pipe flowed full and peak flow estimate was not considered reliable. The flow record for the single-dwelling residential catchment was affected by external electromagnetic field. Time--

Since previous storm: Number of dry hours was not determined for first storms of each rain season. Leader line is separation of rain seasons.

\begin{tabular}{|c|c|c|c|c|c|c|c|c|c|c|c|c|}
\hline \multicolumn{4}{|c|}{ Storm duration } & \multirow{3}{*}{$\begin{array}{l}\text { Rain- } \\
\text { fall } \\
\text { total } \\
\text { (in.) }\end{array}$} & \multirow{3}{*}{ 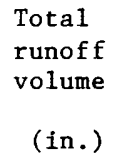 } & \multirow{3}{*}{$\begin{array}{l}\text { Rainfall- } \\
\text { runoff } \\
\text { coeffi- } \\
\text { cient }\end{array}$} & \multirow{3}{*}{$\begin{array}{l}\text { Maximum } \\
20 \text {-minute } \\
\text { rainfall } \\
\text { total } \\
\text { (in.) }\end{array}$} & \multirow{3}{*}{$\begin{array}{l}\text { Peak } \\
\text { flow } \\
\left.\text { (ft } \mathrm{ft}^{3} / \mathrm{s}\right)\end{array}$} & \multirow{3}{*}{$\begin{array}{c}\text { Rainfall } \\
\text { duration } \\
\text { (min) }\end{array}$} & \multirow{3}{*}{$\begin{array}{l}\text { Runoff } \\
\text { duration } \\
\text { (min) }\end{array}$} & \multicolumn{2}{|c|}{ Time } \\
\hline First $r$ & nfall & End of & unoff & & & & & & & & \multirow{2}{*}{$\begin{array}{l}\text { Since } \\
\text { previous } \\
\text { storm } \\
\text { (h) }\end{array}$} & \multirow{2}{*}{$\begin{array}{l}\text { Since } \\
\text { first } \\
\text { storm } \\
\text { (d) }\end{array}$} \\
\hline Date & Time & Date & Time & & & & & & & & & \\
\hline
\end{tabular}

\begin{tabular}{|c|c|c|c|c|c|c|c|c|c|c|c|c|}
\hline \multicolumn{13}{|c|}{ Industrial catchment } \\
\hline $10-28-81$ & 0350 & $10-28-81$ & 1200 & 0.30 & 0.022 & 0.07 & 0.11 & 4.8 & 325 & 250 & . & 1 \\
\hline $11-12-81$ & 2000 & $11-13-81$ & 1232 & 0.58 & 0.054 & 0.09 & 0.06 & 1.0 & 764 & 956 & 352 & 16 \\
\hline $11-17-81$ & 0404 & $11-17-81$ & 0856 & 0.25 & 0.018 & 0.07 & 0.07 & 3.4 & 164 & 248 & 72 & 21 \\
\hline $11-28-81$ & 1044 & $11-28-81$ & 1840 & 0.15 & 0.009 & 0.06 & 0.02 & 0.8 & 296 & 348 & 45 & 32 \\
\hline $12-29-81$ & 1440 & $12-29-81$ & 2230 & 0.18 & 0.024 & 0.13 & 0.03 & 2.7 & 342 & 380 & 194 & 63 \\
\hline $01-01-82$ & 2342 & $01-02-82$ & 0140 & 0.10 & 0.001 & 0.01 & 0.07 & 0.2 & 52 & 48 & 75 & 66 \\
\hline $01-04-82$ & 0718 & $01-04-82$ & 2114 & 0.62 & 0.169 & 0.27 & 0.04 & 7.4 & 646 & 744 & 49 & 69 \\
\hline $01-04-82$ & 2116 & $01-05-82$ & 0320 & 0.16 & 0.042 & 0.26 & 0.04 & 4.1 & 176 & 364 & 1 & 69 \\
\hline $01-19-82$ & 2154 & $01-20-82$ & 0144 & 0.11 & 0.010 & 0.09 & 0.04 & 2.3 & 60 & 188 & 358 & 84 \\
\hline $01-20-82$ & 0710 & $01-20-82$ & 1942 & 0.17 & 0.023 & 0.14 & 0.04 & 3.3 & 700 & 580 & 8 & 85 \\
\hline $01-21-82$ & 0228 & $01-21-82$ & 0640 & 0.06 & 0.005 & 0.08 & 0.03 & 0.9 & 80 & 210 & 15 & 86 \\
\hline $01-26-82$ & 1310 & $01-26-82$ & 1736 & 0.04 & . & . & 0.01 & 0.3 & 116 & 146 & 129 & 91 \\
\hline $02-13-82$ & 1454 & $02-14-82$ & 0208 & 0.06 & 0.005 & 0.08 & 0.01 & 0.5 & 456 & 260 & 432 & 109 \\
\hline $02-14-82$ & 1743 & $02-15-82$ & 0930 & 0.28 & 0.052 & 0.19 & 0.05 & 4.4 & 668 & 910 & 19 & 110 \\
\hline $02-15-82$ & 1942 & $02-16-82$ & 1006 & 0.25 & 0.075 & 0.30 & 0.03 & 5.0 & 564 & 812 & 18 & 111 \\
\hline $03-01-82$ & 0924 & $03-01-82$ & 1610 & 0.21 & 0.033 & 0.16 & 0.04 & 4.0 & 168 & 358 & 316 & 125 \\
\hline $03-01-82$ & 2026 & $03-02-82$ & 0326 & 0.13 & 0.021 & 0.16 & 0.05 & 2.3 & 186 & 344 & 5 & 125 \\
\hline $03-09-82$ & 1900 & $03-10-82$ & 0946 & 0.33 & 0.035 & 0.11 & 0.06 & 2.5 & 590 & 838 & 173 & 133 \\
\hline $03-10-82$ & 2004 & $03-11-82$ & 0706 & 0.20 & 0.048 & 0.24 & 0.07 & 6.2 & 414 & 432 & 15 & 134 \\
\hline $03-11-82$ & 0708 & $03-11-82$ & 1654 & 0.09 & 0.032 & 0.36 & 0.01 & 1.7 & 500 & 578 & 4 & 135 \\
\hline $03-11-82$ & 1654 & $03-11-82$ & 2332 & 0.06 & . & . & 0.04 & 3.9 & 328 & 396 & 5 & 135 \\
\hline $03-14-82$ & 0458 & $03-14-82$ & 1828 & 0.73 & 0.233 & 0.32 & 0.06 & 16 & 548 & 754 & 59 & 138 \\
\hline $03-16-82$ & 0508 & $03-16-82$ & 1426 & 0.22 & 0.065 & 0.30 & 0.04 & 5.5 & 330 & 388 & 39 & 140 \\
\hline $03-16-82$ & 1926 & $03-17-82$ & 0646 & 0.25 & 0.100 & 0.40 & 0.06 & 6.5 & 414 & 658 & 9 & 140 \\
\hline $03-17-82$ & 2148 & $03-18-82$ & 1200 & 0.13 & 0.057 & 0.44 & 0.03 & 3.7 & 564 & 846 & 21 & 141 \\
\hline $03-18-82$ & 1312 & $03-18-82$ & 1712 & 0.05 & 0.015 & 0.30 & 0.03 & 3.8 & 240 & 224 & 2 & 142 \\
\hline $03-18-82$ & 1746 & $03-19-82$ & 0238 & 0.18 & 0.053 & 0.29 & 0.04 & 8.1 & 272 & 430 & 2 & 142 \\
\hline $03-25-82$ & 2054 & $03-26-82$ & 0422 & 0.24 & 0.033 & 0.14 & 0.05 & 4.8 & 308 & 362 & 168 & 149 \\
\hline $03-28-82$ & 0808 & $03-28-82$ & 1208 & 0.09 & 0.005 & 0.06 & 0.02 & 1.1 & 110 & 162 & 50 & 152 \\
\hline $03-28-82$ & 1300 & $03-28-82$ & 1616 & 0.17 & 0.015 & 0.09 & 0.16 & 4.5 & 194 & 194 & 1 & 152 \\
\hline $03-28-82$ & 1616 & $03-28-82$ & 2202 & 0.47 & 0.117 & 0.25 & 0.22 & 18 & 170 & 342 & 1 & 152 \\
\hline $03-28-82$ & 2154 & $03-29-82$ & 0118 & 0.06 & 0.012 & 0.20 & 0.05 & 2.8 & 48 & 196 & 1 & 152 \\
\hline $03-29-82$ & 1112 & $03-29-82$ & 1738 & 0.23 & 0.035 & 0.15 & 0.06 & 7.1 & 202 & 284 & 13 & 153 \\
\hline $03-31-82$ & 1636 & $04-01-82$ & 0826 & 1.01 & 0.136 & 0.14 & 0.13 & 5.8 & 864 & 916 & 1 & 155 \\
\hline $04-10-82$ & 0430 & $04-10-82$ & 0902 & 0.23 & 0.020 & 0.09 & 0.07 & 4.1 & 184 & 240 & 216 & 165 \\
\hline $04-10-82$ & 1122 & $04-10-82$ & 1508 & 0.16 & 0.030 & 0.19 & 0.07 & 5.5 & 122 & 212 & 4 & 165 \\
\hline $04-10-82$ & 1834 & $04-10-82$ & 2340 & 0.22 & 0.034 & 0.16 & 0.04 & 4.1 & 192 & 240 & 5 & 165 \\
\hline $09-24-82$ & 0138 & $09-24-82$ & 0800 & 0.20 & 0.005 & 0.02 & 0.05 & 0.7 & 334 & 230 & . & 1 \\
\hline $10-25-82$ & 0038 & $10-25-82$ & 0556 & 0.19 & 0.002 & 0.01 & 0.14 & 0.6 & 242 & 190 & 720 & 32 \\
\hline $10-26-82$ & 0200 & $10-26-82$ & 1202 & 0.59 & 0.106 & 0.18 & 0.22 & 4.5 & 334 & 562 & 22 & 33 \\
\hline $10-30-82$ & 0038 & $10-30-82$ & 1134 & 0.67 & 0.099 & 0.15 & 0.08 & 8.2 & 474 & 574 & 89 & 37 \\
\hline $11-09-82$ & 1134 & $11-09-82$ & 1828 & 0.45 & 0.045 & 0.10 & 0.06 & 7.4 & 242 & 378 & 18 & 47 \\
\hline $11-18-82$ & 0540 & $11-18-82$ & 1248 & 0.17 & 0.009 & 0.05 & 0.03 & 1.2 & 288 & 260 & 115 & 56 \\
\hline $11-18-82$ & 1640 & $11-19-82$ & 0130 & 0.52 & 0.082 & 0.16 & 0.18 & 13 & 520 & 414 & 6 & 56 \\
\hline $11-29-82$ & 1416 & $11-29-82$ & 2154 & 0.50 & 0.090 & 0.18 & 0.07 & 11 & 380 & 373 & 39 & 67 \\
\hline $12-22-82$ & 0141 & $12-22-82$ & 1436 & 0.64 & 0.199 & 0.31 & 0.06 & 15 & 646 & 666 & 1 & 90 \\
\hline $01-18-83$ & 1642 & $01-19-83$ & 0328 & 0.78 & 0.257 & 0.33 & 0.11 & 28 & 418 & 502 & 56 & 117 \\
\hline $01-22-83$ & 1608 & $01-22-83$ & 2236 & 0.84 & 0.154 & 0.18 & 0.39 & 20 & 190 & 356 & 4 & 121 \\
\hline & & & & & & & & 10 & & & OR & \\
\hline
\end{tabular}


Table 4. Storm characteristics for storms monitored at four catchments-Continued

\begin{tabular}{|c|c|c|c|c|c|c|c|c|c|c|c|c|}
\hline \multicolumn{4}{|c|}{ Storm duration } & \multirow{3}{*}{$\begin{array}{l}\text { Rain- } \\
\text { fall } \\
\text { total } \\
\text { (in.) }\end{array}$} & \multirow{3}{*}{$\begin{array}{l}\text { Total } \\
\text { runoff } \\
\text { volume } \\
\text { (in.) }\end{array}$} & \multirow{3}{*}{$\begin{array}{l}\text { Rainfall- } \\
\text { runoff } \\
\text { coeffi- } \\
\text { cient }\end{array}$} & \multirow{3}{*}{$\begin{array}{l}\text { Maximum } \\
\text { 20-minute } \\
\text { rainfall } \\
\text { total } \\
\text { (in.) }\end{array}$} & \multirow{3}{*}{$\begin{array}{l}\text { Peak } \\
\text { flow } \\
\left(\mathrm{ft}^{3} / \mathrm{s}\right)\end{array}$} & \multirow{3}{*}{$\begin{array}{c}\text { Rainfall } \\
\text { duration } \\
\text { (min) }\end{array}$} & \multirow{3}{*}{$\begin{array}{c}\text { Runoff } \\
\text { duration } \\
\text { (min) }\end{array}$} & \multicolumn{2}{|c|}{ Time } \\
\hline First & rainfall & End of & runoff & & & & & & & & previous & first \\
\hline Date & Time & Date & Time & & & & & & & & (h) & (d) \\
\hline
\end{tabular}

Single-dwelling residential catchment

\begin{tabular}{|c|c|c|c|c|c|c|c|c|c|c|c|}
\hline $10-28-81$ & 0650 & $10-28-81$ & 1015 & 0.30 & $\star 0.041$ & 0.14 & 0.14 & - & 125 & 160 & • \\
\hline $11-12-81$ & 1944 & $11-13-81$ & 0040 & 0.27 & $\star 0.041$ & 0.15 & 0.06 & - & 224 & 268 & 334 \\
\hline $11-13-81$ & 0100 & $11-13-81$ & 1004 & 0.30 & $* 0.083$ & 0.28 & 0.03 & - & 440 & 452 & 2 \\
\hline $11-17-81$ & 0400 & $11-17-81$ & 0756 & 0.25 & $\star 0.044$ & 0.18 & 0.04 & • & 192 & 196 & 72 \\
\hline $03-25-82$ & 2056 & $03-26-82$ & 0240 & 0.20 & $\star 0.031$ & 0.15 & 0.03 & • & 252 & 244 & 168 \\
\hline $03-28-82$ & 1254 & $03-28-82$ & 1412 & 0.09 & $\star 0.018$ & 0.20 & 0.09 & • & 8 & 66 & 3 \\
\hline $03-28-82$ & 1556 & $03-28-82$ & 1714 & 0.16 & $* 0.037$ & 0.23 & 0.15 & • & 24 & 74 & 3 \\
\hline $03-29-82$ & 1122 & $03-29-82$ & 1606 & 0.17 & $* 0.032$ & 0.19 & 0.04 & • & 212 & 166 & 19 \\
\hline $03-29-82$ & 1704 & $03-29-82$ & 1828 & 0.03 & $* 0.005$ & 0.17 & 0.02 & - & 24 & 62 & 2 \\
\hline $03-31-82$ & 1628 & $03-31-82$ & 2320 & 0.95 & $* 0.235$ & 0.25 & 0.09 & • & 388 & 392 & 48 \\
\hline $04-10-82$ & 0446 & $04-10-82$ & 0834 & 0.16 & $\star 0.023$ & 0.14 & 0.04 & • & 186 & 192 & 204 \\
\hline
\end{tabular}

\begin{tabular}{|c|c|c|c|c|c|c|c|c|c|c|c|c|}
\hline $09-24-82$ & 0120 & $09-24-82$ & 0550 & 0.22 & $* 0.028$ & 0.13 & 0.08 & - & 192 & 128 & - & 1 \\
\hline $09-25-82$ & 0948 & $09-25-82$ & 2220 & 0.91 & $\star 0.234$ & 0.26 & 0.06 & - & 712 & 620 & 31 & 2 \\
\hline $10-25-82$ & 0220 & $10-25-82$ & 0432 & 0.09 & $* 0.010$ & 0.11 & 0.08 & - & 46 & 94 & 699 & 32 \\
\hline $10-26-82$ & 0148 & $10-26-82$ & 0512 & 0.69 & $* 0.173$ & 0.25 & 0.20 & - & 146 & 178 & 23 & 33 \\
\hline $12-21-82$ & 1238 & $12-21-82$ & 1606 & 0.10 & 0.017 & 0.17 & 0.04 & 1.2 & 106 & 160 & 511 & 89 \\
\hline $12-21-82$ & 1748 & $12-21-82$ & 2340 & 0.17 & 0.047 & 0.28 & 0.03 & 2.0 & 308 & 322 & 3 & 89 \\
\hline $12-22-82$ & 1446 & $12-22-82$ & 1732 & 0.37 & 0.124 & 0.34 & 0.23 & 15 & 80 & 152 & 5 & 90 \\
\hline $01-18-83$ & 1734 & $01-19-83$ & 0106 & 0.85 & 0.171 & 0.20 & 0.11 & 5.5 & 390 & 380 & 56 & 117 \\
\hline $01-21-83$ & 2100 & $01-22-83$ & 0110 & 0.10 & 0.014 & 0.14 & 0.03 & 1.1 & 172 & 154 & 71 & 120 \\
\hline $01-22-83$ & 0450 & $01-22-83$ & 1354 & 0.73 & 0.173 & 0.24 & 0.11 & 6.9 & 496 & 524 & 5 & 121 \\
\hline $01-24-83$ & 0006 & $01-24-83$ & 0710 & 0.27 & 0.063 & 0.23 & 0.06 & 2.5 & 366 & 412 & 29 & 123 \\
\hline $01-24-83$ & 0830 & $01-24-83$ & 1136 & 0.47 & 0.172 & 0.37 & 0.36 & 19 & 100 & 180 & 3 & 123 \\
\hline $01-26-83$ & 1938 & $01-27-83$ & 1138 & 1.39 & 0.404 & 0.29 & 0.12 & 8.8 & 936 & 908 & 58 & 125 \\
\hline $01-28-83$ & 2124 & $01-29-83$ & 0418 & 0.39 & 0.097 & 0.25 & 0.05 & 4.7 & 386 & 372 & 35 & 127 \\
\hline $02-06-83$ & 0530 & $02-06-83$ & 2400 & 0.85 & 0.138 & 0.16 & 0.07 & 3.6 & 1088 & 1000 & 195 & 136 \\
\hline $02-07-83$ & 2142 & $02-08-83$ & 0104 & 0.44 & 0.113 & 0.26 & 0.14 & 8.5 & 116 & 192 & 16 & 137 \\
\hline $02-12-83$ & 1114 & $02-12-83$ & 2124 & 0.33 & 0.061 & 0.18 & 0.04 & 2.4 & 574 & 538 & 108 & 142 \\
\hline $02-25-83$ & 1340 & $02-25-83$ & 1802 & 0.22 & 0.023 & 0.10 & 0.05 & 1.1 & 250 & 208 & 168 & 155 \\
\hline $02-28-83$ & 1610 & $03-01-83$ & 0438 & 1.11 & 0.301 & 0.27 & 0.16 & 17 & 646 & 638 & 31 & 158 \\
\hline $03-01-83$ & 1806 & $03-01-83$ & 2018 & 0.11 & 0.024 & 0.22 & 0.08 & 2.7 & 28 & 126 & 15 & 159 \\
\hline $03-07-83$ & 0038 & $03-07-83$ & 0420 & 0.14 & 0.016 & 0.11 & 0.03 & 0.7 & 152 & 180 & 100 & 165 \\
\hline $03-10-83$ & 1932 & $03-10-83$ & 2348 & 0.19 & 0.027 & 0.14 & 0.11 & 2.7 & 154 & 144 & 88 & 168 \\
\hline $03-13-83$ & 0554 & $03-13-83$ & 1700 & 0.70 & 0.194 & 0.28 & 0.27 & 12 & 560 & 570 & 55 & 171 \\
\hline $03-16-83$ & 1640 & $03-16-83$ & 2040 & 0.40 & 0.077 & 0.19 & 0.10 & 5.1 & 148 & 218 & 74 & 174 \\
\hline $03-17-83$ & 1836 & $03-18-83$ & 0028 & 0.46 & 0.091 & 0.20 & 0.09 & 5.0 & 326 & 254 & 2 & 175 \\
\hline $03-20-83$ & 1908 & $03-20-83$ & 2352 & 0.29 & 0.044 & 0.15 & 0.05 & 2.5 & 208 & 238 & 64 & 178 \\
\hline $03-22-83$ & 0844 & $03-22-83$ & 1252 & 0.14 & 0.022 & 0.16 & 0.03 & 1.0 & 192 & 200 & 34 & 180 \\
\hline $03-22-83$ & 1634 & $03-22-83$ & 1818 & 0.08 & 0.012 & 0.15 & 0.08 & 1.2 & 10 & 98 & 5 & 180 \\
\hline $03-23-83$ & 1924 & $03-23-83$ & 2346 & 0.57 & 0.134 & 0.24 & 0.10 & 8.2 & 140 & 226 & 27 & 181 \\
\hline $03-24-83$ & 0750 & $03-24-83$ & 1010 & 0.30 & 0.071 & 0.24 & 0.25 & 8.6 & 32 & 140 & 10 & 182 \\
\hline $03-24-83$ & 1358 & $03-24-83$ & 1808 & 0.16 & 0.041 & 0.26 & 0.06 & 2.4 & 222 & 194 & 6 & 182 \\
\hline
\end{tabular}

Multiple-dwelling residential catchment

\begin{tabular}{|c|c|c|c|c|c|c|c|c|c|c|c|c|}
\hline $10-28-81$ & 0650 & $10-28-81$ & 1105 & 0.34 & 0.155 & 0.46 & 0.19 & 12 & 125 & 240 & • & 1 \\
\hline $10-28-81$ & 2005 & $10-28-81$ & 2250 & 0.05 & - & . & 0.03 & 0.5 & 55 & 115 & 9 & 1 \\
\hline $10-29-81$ & 0140 & $10-29-81$ & 0400 & 0.04 & - & . & 0.03 & 0.3 & 70 & 115 & 3 & 2 \\
\hline $11-12-81$ & 1944 & $11-13-81$ & 0100 & 0.27 & 0.045 & 0.17 & 0.06 & 1.0 & 228 & 292 & 352 & 16 \\
\hline $11-13-81$ & 0104 & $11-13-81$ & 0940 & 0.33 & 0.060 & 0.18 & 0.03 & 0.7 & 436 & 516 & 1 & 17 \\
\hline $11-13-81$ & 2228 & $11-14-81$ & 0036 & 0.13 & 0.029 & 0.22 & 0.09 & 2.0 & 44 & 112 & 13 & 17 \\
\hline $11-17-81$ & 0400 & $11-17-81$ & 0800 & 0.29 & 0.061 & 0.21 & 0.10 & 2.5 & 216 & 224 & 71 & 21 \\
\hline $11-26-81$ & 1300 & $11-26-81$ & 1624 & 0.11 & 0.011 & 0.10 & 0.04 & 0.3 & 152 & 168 & 221 & 30 \\
\hline $11-27-81$ & 0704 & $11-27-81$ & 1056 & 0.09 & 0.009 & 0.10 & 0.03 & 0.3 & 160 & 116 & 14 & 31 \\
\hline $12-20-81$ & 0332 & $12-20-81$ & 0958 & 0.09 & 0.013 & 0.14 & 0.03 & 0.4 & 302 & 122 & 241 & 54 \\
\hline $12-20-81$ & 1350 & $12-20-81$ & 1630 & 0.06 & 0.019 & 0.32 & 0.03 & 0.7 & 60 & 136 & 4 & 54 \\
\hline
\end{tabular}


Table 4. Storm characteristics for storms monitored at four catchments-Continued

\begin{tabular}{|c|c|c|c|c|c|c|c|c|c|c|c|c|}
\hline \multicolumn{4}{|c|}{ Storm duration } & \multirow{3}{*}{$\begin{array}{l}\text { Rain- } \\
\text { fall } \\
\text { total } \\
\text { (in.) }\end{array}$} & \multirow{3}{*}{$\begin{array}{l}\text { Total } \\
\text { runoff } \\
\text { volume } \\
\text { (in.) }\end{array}$} & \multirow{3}{*}{$\begin{array}{l}\text { Rainfall- } \\
\text { runoff } \\
\text { coeffi- } \\
\text { cient }\end{array}$} & \multirow{3}{*}{$\begin{array}{l}\text { Maximum } \\
\text { 20-minute } \\
\text { rainfal1 } \\
\text { total } \\
\text { (in.) }\end{array}$} & \multirow{3}{*}{$\begin{array}{l}\text { Peak } \\
\text { flow } \\
\left(\mathrm{ft}^{3} / \mathrm{s}\right)\end{array}$} & \multirow{3}{*}{$\begin{array}{l}\text { Rainfall } \\
\text { duration } \\
\text { (min) }\end{array}$} & \multirow{3}{*}{$\begin{array}{l}\text { Runoff } \\
\text { duration } \\
\text { (min) }\end{array}$} & \multicolumn{2}{|c|}{ Time } \\
\hline First & rainfa11 & End of & runoff & & & & & & & & previous & first \\
\hline Date & Time & Date & Time & & & & & & & & (h) & (d) \\
\hline
\end{tabular}

Multiple-dwelling residential catchment--Continued

\begin{tabular}{|c|c|c|c|c|c|c|c|c|c|c|c|c|}
\hline $12-21-81$ & 0552 & $12-21-81$ & 0908 & 0.06 & 0.007 & 0.12 & 0.04 & 0.3 & 118 & 78 & 14 & 55 \\
\hline $12-29-81$ & 1354 & $12-29-81$ & 2042 & 0.24 & 0.049 & 0.20 & 0.07 & 0.9 & 360 & 350 & 198 & 63 \\
\hline $12-30-81$ & 0146 & $12-30-81$ & 0408 & 0.14 & 0.030 & 0.21 & 0.06 & 1.0 & 130 & 126 & 5 & 64 \\
\hline $01-01-82$ & 0114 & $01-01-82$ & 0354 & 0.08 & 0.013 & 0.16 & 0.05 & 0.7 & 70 & 104 & 46 & 66 \\
\hline $01-01-82$ & 2330 & $01-02-82$ & 0202 & 0.08 & 0.014 & 0.18 & 0.07 & 0.6 & 76 & 108 & 21 & 66 \\
\hline $01-04-82$ & 0656 & $01-04-82$ & 2008 & 0.83 & 0.289 & 0.35 & 0.04 & 2.1 & 694 & 724 & 50 & 69 \\
\hline $01-04-82$ & 2110 & $01-05-82$ & 0304 & 0.33 & 0.140 & 0.42 & 0.06 & 3.2 & 248 & 354 & 2 & 69 \\
\hline $01-19-82$ & 2202 & $01-02-82$ & 0052 & 0.14 & 0.045 & 0.32 & 0.05 & 1.7 & 74 & 148 & 351 & 84 \\
\hline $01-20-82$ & 0752 & $01-20-82$ & 1306 & 0.18 & 0.052 & 0.29 & 0.03 & 1.4 & 242 & 272 & 9 & 85 \\
\hline $01-21-82$ & 0232 & $01-21-82$ & 0456 & 0.06 & 0.011 & 0.18 & 0.03 & 0.5 & 72 & 106 & 7 & 86 \\
\hline $01-21-82$ & 1336 & $01-21-82$ & 1622 & 0.27 & 0.058 & 0.22 & 0.06 & 5.7 & 164 & 120 & 10 & 86 \\
\hline $02-14-82$ & 1740 & $02-14-82$ & 2012 & 0.11 & 0.028 & 0.26 & 0.05 & 1.6 & 80 & 120 & 461 & 110 \\
\hline $02-14-82$ & 2028 & $02-15-82$ & 0130 & 0.17 & 0.046 & 0.27 & 0.03 & 0.8 & 254 & 274 & 3 & 110 \\
\hline $02-15-82$ & 2000 & $02-16-82$ & 0102 & 0.26 & 0.105 & 0.40 & 0.05 & 2.0 & 186 & 280 & 19 & 111 \\
\hline $02-16-82$ & 0338 & $02-16-82$ & 0710 & 0.11 & 0.051 & 0.46 & 0.04 & 1.3 & 112 & 192 & 1 & 112 \\
\hline $03-09-82$ & 1846 & $03-09-82$ & 2320 & 0.16 & 0.028 & 0.18 & 0.04 & 0.6 & 194 & 218 & 199 & 133 \\
\hline $03-10-82$ & 0100 & $03-10-82$ & 0700 & 0.31 & 0.113 & 0.36 & 0.11 & 5.8 & 220 & 328 & 2 & 134 \\
\hline $03-10-82$ & 2306 & $03-11-82$ & 0330 & 0.25 & 0.084 & 0.34 & 0.07 & 3.2 & 202 & 232 & 16 & 134 \\
\hline $03-11-82$ & 0626 & $03-11-82$ & 0900 & 0.05 & 0.012 & 0.24 & 0.03 & 0.5 & 46 & 124 & 3 & 135 \\
\hline $03-11-82$ & 1320 & $03-11-82$ & 1910 & 0.19 & 0.060 & 0.32 & 0.05 & 1.6 & 330 & 308 & 5 & 135 \\
\hline $03-14-82$ & 0146 & $03-14-82$ & 1550 & 0.92 & 0.428 & 0.46 & 0.10 & 8.9 & 750 & 608 & 55 & 138 \\
\hline $03-16-82$ & 0456 & $03-16-82$ & 1316 & 0.44 & 0.153 & 0.35 & 0.07 & 3.8 & 396 & 384 & 37 & 140 \\
\hline $03-16-82$ & 1948 & $03-17-82$ & 0248 & 0.31 & 0.113 & 0.36 & 0.06 & 2.3 & 312 & 438 & 7 & 140 \\
\hline $03-18-82$ & 0350 & $03-18-82$ & 0910 & 0.20 & 0.060 & 0.30 & 0.04 & 1.2 & 208 & 292 & 6 & 142 \\
\hline $03-18-82$ & 1308 & $03-18-82$ & 1600 & 0.17 & 0.073 & 0.43 & 0.09 & 4.9 & 54 & 152 & 4 & 142 \\
\hline $03-18-82$ & 1836 & $03-18-82$ & 2220 & 0.10 & 0.022 & 0.22 & 0.03 & 0.6 & 148 & 174 & 3 & 142 \\
\hline $03-25-82$ & 2100 & $03-26-82$ & 0348 & 0.26 & 0.063 & 0.24 & 0.05 & 1.1 & 256 & 324 & 167 & 149 \\
\hline $03-28-82$ & 0818 & $03-28-82$ & 1152 & 0.06 & 0.010 & 0.17 & 0.02 & 0.4 & 100 & 156 & 52 & 152 \\
\hline $03-28-82$ & 1246 & $03-28-82$ & 1510 & 0.06 & 0.020 & 0.33 & 0.06 & 1.7 & 16 & 122 & 1 & 152 \\
\hline $03-29-82$ & 1104 & $03-29-82$ & 1700 & 0.27 & 0.092 & 0.34 & 0.06 & 2.8 & 236 & 306 & 20 & 153 \\
\hline $03-29-82$ & 1702 & $03-29-82$ & 2024 & 0.10 & 0.042 & 0.42 & 0.09 & 2.9 & 30 & 200 & 1 & 153 \\
\hline $03-31-82$ & 1630 & $04-01-82$ & 1030 & 1.07 & 0.580 & 0.54 & 0.12 & 6.2 & 942 & 1080 & 44 & 155 \\
\hline $04-01-82$ & 1602 & $04-01-82$ & 1844 & 0.15 & 0.055 & 0.37 & 0.10 & 3.0 & 48 & 162 & 6 & 156 \\
\hline $04-10-82$ & 0448 & $04-10-82$ & 0920 & 0.17 & 0.046 & 0.27 & 0.04 & 1.0 & 172 & 272 & 202 & 165 \\
\hline $04-10-82$ & 1056 & $04-10-82$ & 1444 & 0.19 & 0.059 & 0.31 & 0.08 & 2.5 & 134 & 192 & 2 & 165 \\
\hline $04-10-82$ & 1834 & $04-10-82$ & 2332 & 0.25 & 0.083 & 0.33 & 0.04 & 1.8 & 202 & 264 & 4 & 165 \\
\hline $04-11-82$ & 0108 & $04-11-82$ & 0258 & 0.04 & 0.009 & 0.22 & 0.02 & 0.3 & 40 & 104 & 2 & 166 \\
\hline $04-11-82$ & 0516 & $04-11-82$ & 0810 & 0.10 & 0.042 & 0.42 & 0.05 & 1.5 & 66 & 168 & 2 & 166 \\
\hline $09-24-82$ & 0144 & $09-24-82$ & 0658 & 0.23 & 0.069 & 0.30 & 0.08 & 3.1 & 208 & 208 & - & 1 \\
\hline $09-24-82$ & 0658 & $09-24-82$ & 1022 & 0.05 & 0.005 & 0.10 & 0.02 & 0.2 & 158 & 118 & 1 & 1 \\
\hline $09-25-82$ & 1024 & $09-25-82$ & 1150 & 0.02 & 0.003 & 0.15 & 0.02 & 0.2 & 86 & 62 & 23 & 2 \\
\hline $09-25-82$ & 1200 & $09-26-82$ & 0232 & 0.99 & 0.364 & 0.37 & 0.07 & 4.9 & 814 & 850 & 1 & 2 \\
\hline $10-25-82$ & 0146 & $10-25-82$ & 0458 & 0.09 & 0.021 & 0.23 & 0.08 & 1.5 & 72 & 118 & 652 & 32 \\
\hline $10-26-82$ & 0150 & $10-26-82$ & 0602 & 0.71 & 0.528 & 0.74 & 0.21 & 22 & 150 & 226 & 23 & 33 \\
\hline $10-30-82$ & 0032 & $10-30-82$ & 0956 & 0.65 & 0.242 & 0.37 & 0.06 & 3.2 & 472 & 506 & 89 & 37 \\
\hline $10-30-82$ & 1416 & $10-30-82$ & 1732 & 0.27 & 0.242 & 0.90 & 0.23 & 20 & 118 & 180 & 6 & 37 \\
\hline $11-09-82$ & 1028 & $11-09-82$ & 1744 & 0.45 & 0.170 & 0.38 & 0.04 & 4.4 & 324 & 340 & 16 & 47 \\
\hline $11-18-82$ & 0508 & $11-18-82$ & 1212 & 0.37 & 0.130 & 0.35 & 0.07 & 5.1 & 336 & 268 & 192 & 56 \\
\hline $11-28-82$ & 1704 & $11-28-82$ & 2328 & 0.51 & 0.290 & 0.57 & 0.12 & 12 & 288 & 286 & 21 & 66 \\
\hline $11-29-82$ & 1410 & $11-29-82$ & 2238 & 0.76 & 0.493 & 0.65 & 0.16 & 22 & 416 & 464 & 10 & 67 \\
\hline $11-30-82$ & 0002 & $11-30-82$ & 0250 & 0.09 & 0.024 & 0.27 & 0.05 & 0.7 & 86 & 154 & 3 & 68 \\
\hline $11-30-82$ & 0356 & $11-30-82$ & 0910 & 0.45 & 0.348 & 0.77 & 0.18 & 19 & 166 & 314 & 3 & 68 \\
\hline $12-21-82$ & 1238 & $12-21-82$ & 1538 & 0.11 & 0.021 & 0.19 & 0.04 & 0.7 & 86 & 146 & 504 & 89 \\
\hline $12-21-82$ & 1750 & $12-22-82$ & 0006 & 0.21 & 0.062 & 0.30 & 0.04 & 1.7 & 316 & 350 & 4 & 89 \\
\hline $12-22-82$ & 0124 & $12-22-82$ & 1404 & 0.71 & 0.330 & 0.46 & 0.08 & 6.1 & 668 & 712 & 3 & 90 \\
\hline $01-18-83$ & 1814 & $01-19-83$ & 0204 & 0.95 & 0.462 & 0.49 & 0.11 & 11 & 350 & 444 & 56 & 117 \\
\hline $01-21-83$ & 1444 & $01-21-83$ & 1802 & 0.04 & 0.003 & 0.08 & 0.02 & 0.1 & 98 & 98 & 63 & 120 \\
\hline $01-21-83$ & 2054 & $01-22-83$ & 0132 & 0.11 & 0.030 & 0.27 & 0.04 & 1.5 & 154 & 188 & 4 & 120 \\
\hline $01-22-83$ & 0320 & $01-22-83$ & 1628 & 0.86 & 0.500 & 0.58 & 0.13 & 13 & 674 & 666 & 4 & 121 \\
\hline
\end{tabular}


Table 4. Storm characteristics for storms monitored at four catchments-Continued

\begin{tabular}{|c|c|c|c|c|c|c|c|c|c|c|c|c|}
\hline \multicolumn{4}{|c|}{ Storm duration } & \multirow{3}{*}{$\begin{array}{l}\text { Rain- } \\
\text { fall } \\
\text { total } \\
\text { (in.) }\end{array}$} & \multirow{3}{*}{$\begin{array}{l}\text { Total } \\
\text { runoff } \\
\text { volume } \\
\text { (in.) }\end{array}$} & \multirow{3}{*}{$\begin{array}{l}\text { Rainfall- } \\
\text { runoff } \\
\text { coeffi- } \\
\text { cient }\end{array}$} & \multirow{3}{*}{$\begin{array}{l}\text { Maximum } \\
\text { 20-minute } \\
\text { rainfall } \\
\text { total } \\
\text { (in.) }\end{array}$} & \multirow{3}{*}{$\begin{array}{l}\text { Peak } \\
\text { flow } \\
\left(\mathrm{ft}^{3} / \mathrm{s}\right)\end{array}$} & \multirow{3}{*}{$\begin{array}{l}\text { Rainfall } \\
\text { duration } \\
\text { (min) }\end{array}$} & \multirow{3}{*}{$\begin{array}{l}\text { Runoff } \\
\text { duration } \\
\text { (min) }\end{array}$} & \multicolumn{2}{|c|}{ Time } \\
\hline First & rainfall & End of & runoff & & & & & & & & \multirow{2}{*}{$\begin{array}{l}\text { Since } \\
\text { previous } \\
\text { storm } \\
(h)\end{array}$} & \multirow{2}{*}{$\begin{array}{l}\text { Since } \\
\text { first } \\
\text { storm } \\
\text { (d) }\end{array}$} \\
\hline Date & Time & Date & Time & & & & & & & & & \\
\hline
\end{tabular}

Multiple-dwelling residential catchment--Continued

$\begin{array}{llllll}01-22-83 & 1616 & 01-22-83 & 2400 & 0.78 & 0.787 \\ 01-23-83 & 2230 & 01-24-83 & 0840 & 0.34 & 0.155 \\ 01-24-83 & 0832 & 01-24-83 & 1422 & 0.47 & 0.443 \\ 01-26-83 & 1946 & 01-27-83 & 1600 & 1.69 & 1.188 \\ 01-28-83 & 2138 & 01-29-83 & 0552 & 0.47 & 0.262 \\ 02-07-83 & 1526 & 02-08-83 & 0320 & 0.48 & 0.371 \\ 02-12-83 & 1016 & 02-13-83 & 0006 & 0.40 & 0.100 \\ 02-13-83 & 0156 & 02-13-82 & 0438 & 0.11 & 0.037 \\ 02-18-83 & 0718 & 02-18-83 & 1018 & 0.24 & 0.122 \\ 02-25-83 & 1328 & 02-25-83 & 2158 & 0.35 & 0.128 \\ 02-28-83 & 0652 & 02-28-83 & 1018 & 0.04 & 0.009 \\ 02-28-83 & 1624 & 02-28-83 & 2224 & 0.21 & 0.102 \\ 02-28-83 & 2204 & 03-01-83 & 0626 & 0.92 & 0.965 \\ 03-16-83 & 1642 & 03-16-83 & 2218 & 0.40 & 0.213 \\ 03-17-83 & 1552 & 03-18-83 & 0532 & 0.57 & 0.375 \\ 03-20-83 & 1918 & 03-21-83 & 0128 & 0.33 & 0.136 \\ 03-23-83 & 1918 & 03-24-83 & 0052 & 0.57 & 0.503 \\ 03-24-83 & 0610 & 03-24-83 & 1124 & 0.22 & 0.199 \\ 03-24-83 & 1406 & 03-24-83 & 1914 & 0.22 & 0.142 \\ 03-24-83 & 2048 & 03-24-83 & 2332 & 0.07 & 0.039\end{array}$

$\begin{array}{ll}1.01 & 0.34 \\ 0.46 & 0.10 \\ 0.94 & 0.40 \\ 0.70 & 0.12 \\ 0.56 & 0.10 \\ 0.77 & 0.12 \\ 0.25 & 0.05 \\ 0.34 & 0.08 \\ 0.51 & 0.17 \\ 0.37 & 0.05 \\ 0.22 & 0.02 \\ 0.49 & 0.09 \\ 1.05 & 0.18 \\ 0.53 & 0.10 \\ 0.66 & 0.10 \\ 0.41 & 0.05 \\ 0.88 & 0.11 \\ 0.90 & 0.14 \\ 0.65 & 0.06 \\ 0.56 & 0.05\end{array}$

$\begin{array}{cr}3.8 & 218 \\ 18 & 470 \\ 9.5 & 98 \\ 16 & 984 \\ 2.5 & 324 \\ 2.1 & 500 \\ 8.9 & 172 \\ 3.0 & 74 \\ 0.3 & 448 \\ 4.5 & 222 \\ . & 300 \\ 8.5 & 146 \\ 13 & 654 \\ 4.6 & 226 \\ 19 & 148 \\ 14 & 144 \\ 6.2 & 162 \\ 1.4 & 66\end{array}$

450
502
340
1176
466
690
680
152
178
456
174
332
480
314
800
338
294
208
272
146

$\begin{array}{rr}2 & 121 \\ 27 & 122 \\ 2 & 123 \\ 48 & 125 \\ 35 & 127 \\ 17 & 137 \\ 94 & 142 \\ 4 & 143 \\ 124 & 148 \\ 173 & 155 \\ 22 & 158 \\ 9 & 158 \\ 2 & 158 \\ 74 & 174 \\ 21 & 175 \\ 65 & 178 \\ 23 & 181 \\ 9 & 182 \\ 6 & 182 \\ 4 & 182\end{array}$

Commercial catchment

$\begin{array}{lllll}10-28-81 & 0650 & 10-28-81 & 1250 & 0.27 \\ 11-17-81 & 0356 & 11-17-81 & 0816 & 0.25 \\ 11-26-81 & 1236 & 11-26-81 & 1700 & 0.11 \\ 11-27-81 & 0752 & 11-27-81 & 1236 & 0.09 \\ 11-27-81 & 1408 & 11-27-81 & 1640 & 0.03 \\ 11-27-81 & 1752 & 11-27-81 & 2036 & 0.06 \\ 11-28-81 & 1152 & 11-28-81 & 1548 & 0.07 \\ 12-20-81 & 0326 & 12-20-81 & 1718 & 0.14 \\ 12-21-81 & 0710 & 12-21-81 & 1020 & 0.03 \\ 12-29-81 & 1414 & 12-29-81 & 2150 & 0.21 \\ 12-30-81 & 0142 & 12-30-81 & 0444 & 0.13 \\ 01-01-82 & 0128 & 01-01-82 & 0420 & 0.09 \\ 01-01-82 & 2344 & 01-02-82 & 0238 & 0.07 \\ 01-02-82 & 0558 & 01-02-82 & 0820 & 0.02 \\ 01-02-82 & 1312 & 01-02-82 & 1520 & 0.04 \\ 01-04-82 & 0732 & 01-04-82 & 2100 & 0.71 \\ 01-04-82 & 2112 & 01-05-82 & 0450 & 0.26 \\ 01-05-82 & 1356 & 01-05-82 & 1600 & 0.02 \\ 01-19-82 & 2202 & 01-20-82 & 0100 & 0.09 \\ 01-20-82 & 0754 & 01-20-82 & 1300 & 0.13 \\ 01-20-82 & 1632 & 01-20-82 & 1800 & 0.02 \\ 01-21-82 & 1326 & 01-21-82 & 1718 & 0.20 \\ 01-26-82 & 1418 & 01-26-82 & 1630 & 0.06 \\ 02-14-82 & 1744 & 02-14-82 & 2046 & 0.10 \\ 02-14-82 & 2032 & 02-15-82 & 0248 & 0.18 \\ 02-15-82 & 0812 & 02-15-82 & 1032 & 0.05 \\ 02-15-82 & 1958 & 02-16-82 & 0140 & 0.22 \\ 02-16-82 & 0314 & 02-16-82 & 1002 & 0.15 \\ 03-09-82 & 1838 & 03-09-82 & 2344 & 0.17 \\ 03-09-82 & 2350 & 03-10-82 & 0640 & 0.26 \\ 03-10-82 & 2258 & 03-11-82 & 0330 & 0.28 \\ 03-11-82 & 0624 & 03-11-82 & 1024 & 0.06 \\ 03-11-82 & 1008 & 03-11-82 & 2040 & 0.26 \\ 03-14-82 & 0312 & 03-14-82 & 1630 & 0.89 \\ 03-16-82 & 0512 & 03-16-82 & 1338 & 0.41 \\ 03-16-82 & 1946 & 03-17-82 & 0222 & 0.29 \\ 03-17-82 & 2202 & 03-18-82 & 0028 & 0.03\end{array}$

\begin{tabular}{|c|c|c|}
\hline 0.315 & 1.17 & 0.18 \\
\hline 0.234 & 0.94 & 0.08 \\
\hline 0.069 & 0.63 & 0.03 \\
\hline 0.059 & 0.66 & 0.03 \\
\hline 0.007 & 0.23 & 0.03 \\
\hline 0.032 & 0.53 & 0.06 \\
\hline 0.031 & 0.44 & 0.02 \\
\hline 0.166 & 1.19 & 0.02 \\
\hline 0.024 & 0.80 & 0.02 \\
\hline 0.183 & 0.87 & 0.04 \\
\hline 0.131 & 1.01 & 0.05 \\
\hline 0.084 & 0.93 & 0.05 \\
\hline 0.054 & 0.77 & 0.04 \\
\hline . & 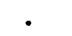 & 0.02 \\
\hline 0.009 & 0.23 & 0.03 \\
\hline 0.772 & 1.09 & 0.04 \\
\hline 0.310 & 1.19 & 0.06 \\
\hline • & - & 0.02 \\
\hline 0.085 & 0.94 & 0.03 \\
\hline 0.117 & 0.90 & 0.03 \\
\hline • & • & 0.02 \\
\hline 0.206 & 1.03 & 0.09 \\
\hline 0.048 & 0.80 & 0.03 \\
\hline 0.096 & 0.96 & 0.05 \\
\hline 0.214 & 1.19 & 0.03 \\
\hline 0.049 & 0.98 & 0.04 \\
\hline 0.274 & 1.24 & 0.05 \\
\hline 0.185 & 1.23 & 0.04 \\
\hline 0.151 & 0.89 & 0.03 \\
\hline 0.276 & 1.06 & 0.08 \\
\hline 0.285 & 1.02 & 0.06 \\
\hline 0.068 & 1.13 & 0.03 \\
\hline 0.201 & 0.77 & 0.03 \\
\hline 0.959 & 1.08 & 0.15 \\
\hline 0.439 & 1.07 & 0.06 \\
\hline 0.320 & 1.10 & 0.08 \\
\hline 0.016 & 0.53 & 0.03 \\
\hline
\end{tabular}

$\begin{array}{rr}19 & 105 \\ 14 & 160 \\ 3.1 & 168 \\ 3.4 & 104 \\ 0.8 & 36 \\ 9.5 & 8 \\ 1.4 & 144 \\ 3.7 & 692 \\ 1.7 & 22 \\ 7.0 & 338 \\ 9.3 & 54 \\ 9.0 & 66 \\ 4.0 & 60 \\ 0.6 & 20 \\ 0.6 & 32 \\ 7.2 & 656 \\ 9.8 & 230 \\ 0.8 & 8 \\ 6.1 & 58 \\ 5.4 & 226 \\ 1.0 & 4 \\ 20 & 98 \\ 4.5 & 98 \\ 7.9 & 78 \\ 4.3 & 290 \\ 3.8 & 46 \\ 7.9 & 180 \\ 6.4 & 292 \\ 4.5 & 304 \\ 14 & 390 \\ 10 & 208 \\ 3.7 & 224 \\ 5.9 & 454 \\ 30 & 664 \\ 11 & 492 \\ 15 & 298 \\ 1.6 & 152 \\ & \end{array}$

330
240
224
244
132
156
180
792
152
418
168
136
148
106
92
786
434
90
146
264
62
210
110
160
360
132
320
392
266
404
254
220
610
768
458
380
112

$\begin{array}{rr}72 & 1 \\ 222 & 21 \\ 16 & 30 \\ 4 & 31 \\ 1 & 31 \\ 16 & 32 \\ 240 & 54 \\ 16 & 55 \\ 199 & 63 \\ 6 & 64 \\ 47 & 66 \\ 21 & 66 \\ 5 & 67 \\ 7 & 67 \\ 42 & 69 \\ 3 & 69 \\ 13 & 70 \\ 341 & 84 \\ 9 & 85 \\ 5 & 85 \\ 10 & 86 \\ 119 & 91 \\ 453 & 110 \\ 1 & 110 \\ 7 & 111 \\ 11 & 111 \\ 4 & 112 \\ 189 & 133 \\ 2 & 133 \\ 18 & 134 \\ 5 & 135 \\ 3 & 135 \\ 58 & 138 \\ 39 & 140 \\ 21 & 140 \\ & 141\end{array}$


Table 4. Storm characteristics for storms monitored at four catchments-Continued

\begin{tabular}{|c|c|c|c|c|c|c|c|c|c|c|c|c|}
\hline \multicolumn{4}{|c|}{ Storm duration } & \multirow{3}{*}{$\begin{array}{l}\text { Rain- } \\
\text { fall } \\
\text { total } \\
\text { (1n.) }\end{array}$} & \multirow{3}{*}{$\begin{array}{l}\text { Total } \\
\text { runoff } \\
\text { volume } \\
\text { (in.) }\end{array}$} & \multirow{3}{*}{$\begin{array}{l}\text { Rainfall- } \\
\text { runoff } \\
\text { coeffi- } \\
\text { cient }\end{array}$} & \multirow{3}{*}{$\begin{array}{l}\text { Maximum } \\
\text { 20-minute } \\
\text { rainfall } \\
\text { total } \\
\text { (1n.) }\end{array}$} & \multirow{3}{*}{$\begin{array}{l}\text { Peak } \\
\text { flow } \\
\left(\mathrm{ft}^{3} / \mathrm{s}\right)\end{array}$} & \multirow{3}{*}{$\begin{array}{c}\text { Rainfall } \\
\text { duration } \\
\text { (min) }\end{array}$} & \multirow{3}{*}{$\begin{array}{l}\text { Runoff } \\
\text { duration } \\
\text { (min) }\end{array}$} & \multicolumn{2}{|c|}{ Time } \\
\hline \multicolumn{2}{|c|}{ First rainfall } & \multicolumn{2}{|c|}{ End of runoff } & & & & & & & & \multirow{2}{*}{$\begin{array}{l}\text { Since } \\
\text { previous } \\
\text { storm } \\
\text { (h) }\end{array}$} & \multirow{2}{*}{$\begin{array}{c}\text { Since } \\
\text { first } \\
\text { storm } \\
\text { (d) }\end{array}$} \\
\hline Date & Time & Date & Time & & & & & & & & & \\
\hline \multicolumn{13}{|c|}{ Commercial catchment--Continued } \\
\hline $03-18-82$ & 0348 & $03-18-82$ & 0956 & 0.22 & 0.211 & 0.96 & 0.04 & 5.9 & 296 & 342 & 5 & 142 \\
\hline $03-18-82$ & 1308 & $03-18-82$ & 1600 & 0.14 & 0.151 & 1.08 & 0.08 & 13 & 146 & 150 & 4 & 142 \\
\hline $03-18-82$ & 1834 & $03-18-82$ & 2328 & 0.09 & 0.101 & 1.12 & 0.03 & 4.8 & 120 & 246 & 4 & 142 \\
\hline $03-25-82$ & 2208 & $03-26-82$ & 0250 & 0.19 & 0.148 & 0.78 & 0.04 & 4.9 & 190 & 252 & 170 & 149 \\
\hline $03-28-82$ & 0836 & $03-28-82$ & 1108 & 0.06 & 0.029 & 0.48 & 0.03 & 2.2 & 80 & 106 & 55 & 152 \\
\hline $03-28-82$ & 1232 & $03-28-82$ & 1430 & 0.07 & 0.053 & 0.76 & 0.05 & 6.0 & 24 & 98 & 2 & 152 \\
\hline $03-28-82$ & 1548 & $03-28-82$ & 1724 & 0.11 & 0.079 & 0.72 & 0.11 & 12 & 16 & 92 & 3 & 152 \\
\hline $03-29-82$ & 1140 & $03-29-82$ & 1658 & 0.17 & 0.210 & 1.24 & 0.05 & 9.5 & 288 & 282 & 13 & 153 \\
\hline $03-29-82$ & 1700 & $03-29-82$ & 1910 & 0.07 & 0.101 & 1.44 & 0.05 & 12 & 28 & 126 & 2 & 153 \\
\hline $03-31-82$ & 1630 & $04-01-82$ & 0920 & 1.05 & 1.179 & 1.12 & 0.12 & 20 & 900 & 1006 & 49 & 155 \\
\hline $04-01-82$ & 1544 & $04-01-82$ & 1908 & 0.27 & 0.297 & 1.10 & 0.20 & 30 & 80 & 184 & 8 & 156 \\
\hline $04-10-82$ & 0444 & $04-10-82$ & 0934 & 0.18 & 0.174 & 0.97 & 0.05 & 8.0 & 182 & 258 & 216 & 165 \\
\hline $04-10-82$ & 1112 & $04-10-82$ & 1434 & 0.17 & 0.159 & 0.94 & 0.07 & 11 & 146 & 190 & 5 & 165 \\
\hline $04-10-82$ & 1846 & $04-11-82$ & 0020 & 0.22 & 0.231 & 1.05 & 0.04 & 8.1 & 190 & 306 & 8 & 165 \\
\hline $04-11-82$ & 0106 & $04-11-82$ & 0320 & 0.04 & & . & 0.03 & 2.3 & 30 & 122 & 28 & 166 \\
\hline $04-11-82$ & 0516 & $04-11-82$ & 0836 & 0.12 & 0.121 & 1.01 & 0.07 & 7.5 & 82 & 196 & 5 & 166 \\
\hline $09-24-82$ & 0132 & $09-24-82$ & 0812 & 0.24 & 0.231 & 0.96 & 0.09 & 16 & 200 & 338 & . & 1 \\
\hline $10-24-82$ & 0548 & $10-24-82$ & 0902 & 0.02 & 0.007 & 0.35 & 0.02 & 0.3 & 26 & 122 & 675 & 31 \\
\hline $10-25-82$ & 0244 & $10-25-82$ & 0518 & 0.05 & 0.052 & 1.04 & 0.05 & 5.0 & 18 & 142 & 18 & 32 \\
\hline $10-26-82$ & 0146 & $10-26-82$ & 0626 & 0.61 & 0.844 & 1.38 & 0.20 & 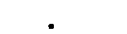 & 148 & 278 & 23 & 33 \\
\hline $11-08-82$ & 1710 & $11-08-82$ & 2028 & 0.14 & 0.155 & 1.11 & 0.07 & 14 & 106 & 182 & 222 & 46 \\
\hline $11-09-82$ & 1020 & $11-09-82$ & 1850 & 0.47 & 0.648 & 1.38 & 0.07 & 14 & 296 & 500 & 14 & 47 \\
\hline $12-21-82$ & 1222 & $12-21-82$ & 1632 & 0.09 & 0.076 & 0.84 & 0.04 & 4.6 & 90 & 220 & 29 & 89 \\
\hline $12-21-82$ & 1744 & $12-22-82$ & 0136 & 0.18 & 0.201 & 1.12 & 0.04 & 7.2 & 326 & 454 & 4 & 89 \\
\hline $12-22-82$ & 0134 & $12-22-82$ & 1850 & 1.05 & 1.525 & 1.45 & 0.18 & . & 866 & 1032 & I & 90 \\
\hline $01-18-83$ & 1614 & $01-19-83$ & 0134 & 0.88 & 1.080 & 1.23 & 0.13 & . & 444 & 498 & 56 & 117 \\
\hline $01-24-83$ & 0002 & $01-24-83$ & 0824 & 0.30 & 0.266 & 0.89 & 0.08 & II & 370 & 486 & 27 & 123 \\
\hline $01-24-82$ & 0816 & $01-24-83$ & 1336 & 0.48 & 0.705 & 1.47 & 0.39 & . & 100 & 310 & 1 & 123 \\
\hline $02-28-83$ & 0646 & $02-28-83$ & 1040 & 0.05 & 0.027 & 0.54 & 0.02 & 1.5 & 44 & 202 & 21 & 158 \\
\hline $02-28-83$ & 1636 & $03-01-83$ & 0832 & 1.10 & 1.472 & 1.34 & 0.15 & 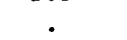 & 610 & 868 & 9 & 158 \\
\hline $03-01-83$ & 1806 & $03-02-83$ & 0048 & 0.07 & 0.101 & 1.44 & 0.06 & 8.7 & 18 & 388 & 15 & 159 \\
\hline $03-02-83$ & 0204 & $03-02-83$ & 0806 & 0.08 & 0.106 & 1.32 & 0.04 & 4.5 & 146 & 338 & 8 & 160 \\
\hline $03-16-83$ & 1640 & $03-16-83$ & 2110 & 0.40 & 0.451 & 1.13 & 0.11 & 20 & 144 & 256 & 74 & 174 \\
\hline $03-22-83$ & 1630 & $03-22-83$ & 1944 & 0.07 & 0.061 & 0.87 & 0.07 & 6.7 & 6 & 188 & 4 & 180 \\
\hline $03-22-83$ & 2104 & $03-23-83$ & 0038 & 0.03 & 0.026 & 0.87 & 0.02 & 1.3 & 30 & 186 & 5 & 180 \\
\hline $03-23-83$ & 1934 & $03-24-83$ & 0308 & 0.57 & 0.873 & 1.53 & 0.11 & . & 130 & 430 & 22 & 181 \\
\hline $03-24-83$ & 0652 & $03-24-83$ & 1116 & 0.30 & 0.394 & 1.31 & 0.24 & . & 92 & 210 & 9 & 182 \\
\hline
\end{tabular}
field.

*Calculated using rainfall-runoff equation; original flow record affected by external electromagnetic 
Table 5. Statistical summary of storm characteristics for storms monitored at four catchments

\begin{tabular}{|c|c|c|c|c|c|}
\hline Storm characteristic & Mean & $\begin{array}{l}\text { Standard } \\
\text { error of } \\
\text { mean }\end{array}$ & $\begin{array}{l}\text { Standard } \\
\text { deviation }\end{array}$ & Maximum & Minimum \\
\hline \multicolumn{6}{|c|}{ Industrial catchment (number of storms $=47$ ) } \\
\hline $\begin{array}{l}\text { Rainfall total (in.) } \\
\text { Runoff volume (in.) } \\
\text { Rainfall-runoff coefficient } \\
\text { Maximum 20-minute rainfall } \\
\text { total (in.) } \\
\text { Rainfall duration (min) } \\
\text { Runoff duration (min) }\end{array}$ & $\begin{array}{r}0.32 \\
0.060 \\
0.18 \\
\\
0.08 \\
355 \\
436\end{array}$ & $\begin{array}{r}0.04 \\
0.009 \\
0.02 \\
0.01 \\
35 \\
31\end{array}$ & $\begin{array}{r}0.24 \\
0.062 \\
0.11 \\
0.07 \\
237 \\
209\end{array}$ & $\begin{array}{r}1.01 \\
0.257 \\
0.44 \\
\\
0.39 \\
864 \\
956\end{array}$ & $\begin{array}{r}0.05 \\
0.001 \\
0.01 \\
\\
0.01 \\
48 \\
48\end{array}$ \\
\hline \multicolumn{6}{|c|}{ Single-dwelling residential catchment (number of storms $=42$ ) } \\
\hline $\begin{array}{l}\text { Rainfall total (in.) } \\
\text { Runoff volume (in.) } \\
\text { Rainfall-runoff coefficient } \\
\text { Maximum 20-minute rainfall } \\
\quad \text { total (in.) } \\
\text { Rainfall duration (min) } \\
\text { Runoff duration (min) }\end{array}$ & $\begin{array}{r}0.38 \\
0.088 \\
0.21 \\
\\
0.10 \\
270 \\
286\end{array}$ & $\begin{array}{r}0.05 \\
0.014 \\
0.01 \\
\\
0.01 \\
38 \\
33\end{array}$ & $\begin{array}{r}0.32 \\
0.088 \\
0.06 \\
0.07 \\
244 \\
215\end{array}$ & $\begin{array}{r}1.39 \\
0.404 \\
0.37 \\
0.36 \\
1,088 \\
1,000\end{array}$ & $\begin{array}{r}0.03 \\
0.005 \\
0.10 \\
0.02 \\
8 \\
62\end{array}$ \\
\hline \multicolumn{6}{|c|}{ Multiple-dwelling residential catchment (number of storms $=88$ ) } \\
\hline $\begin{array}{l}\text { Rainfall total (in.) } \\
\text { Runoff volume (in.) } \\
\text { Rainfall-runoff coefficient } \\
\text { Maximum 20-minute rainfall } \\
\quad \text { total (in.) } \\
\text { Rainfall duration (min) } \\
\text { Runoff duration (min) }\end{array}$ & $\begin{array}{r}0.32 \\
0.161 \\
0.39 \\
\\
0.08 \\
247 \\
307\end{array}$ & $\begin{array}{r}0.03 \\
0.023 \\
0.02 \\
0.01 \\
23 \\
23\end{array}$ & $\begin{array}{r}0.30 \\
0.216 \\
0.22 \\
\\
0.06 \\
214 \\
218\end{array}$ & $\begin{array}{r}1.69 \\
1.188 \\
1.05 \\
0.40 \\
984 \\
1,176\end{array}$ & $\begin{array}{r}0.02 \\
0.003 \\
0.08 \\
0.02 \\
16 \\
62\end{array}$ \\
\hline \multicolumn{6}{|c|}{ Commercial catchment ${ }^{1}$ (number of storms $=49$ ) } \\
\hline $\begin{array}{l}\text { Rainfall total (in.) } \\
\text { Runoff volume (in.) } \\
\text { Rainfall-runoff coefficient } \\
\text { Maximum 20-minute rainfall } \\
\quad \text { total (in.) } \\
\text { Rainfall duration (min) } \\
\text { Runoff duration (min) }\end{array}$ & $\begin{array}{r}0.19 \\
0.198 \\
0.93 \\
0.06 \\
206 \\
286\end{array}$ & $\begin{array}{r}0.03 \\
0.032 \\
0.04\end{array}$ & $\begin{array}{r}0.20 \\
0.226 \\
0.26\end{array}$ & $\begin{array}{r}1.05 \\
1.179 \\
1.44 \\
\\
0.20 \\
900 \\
1,006\end{array}$ & $\begin{array}{r}0.03 \\
0.007 \\
0.22 \\
\\
0.02 \\
8 \\
92\end{array}$ \\
\hline
\end{tabular}

lonly first rain season storms included because of variable backwater situation during second rain season (01tmann and others, 1987). 
Table 6. Statistical summary of rainfall quality data: Industrial site

[Statistical calculations include analytical detection limit concentration for those analyses which are reported to be less than detection limit. Other pesticides were analyzed for but not detected and are given at the end of this table. <, actual value is less than value shown]

\begin{tabular}{|c|c|c|c|c|c|c|c|}
\hline Property or constituent & $\begin{array}{l}\text { Number } \\
\text { of } \\
\text { samples }\end{array}$ & Mean & Median & $\begin{array}{c}\text { Standard } \\
\text { error } \\
\text { of mean }\end{array}$ & $\begin{array}{l}\text { Standard } \\
\text { deviation }\end{array}$ & Maximum & Minimum \\
\hline \multicolumn{8}{|l|}{ INORGANICS } \\
\hline \multicolumn{8}{|l|}{ Field measurements } \\
\hline Specific conductance $\left(\mu \mathrm{S} / \mathrm{cm}\right.$ at $\left.25^{\circ} \mathrm{C}\right)--$ & 36 & 14 & 11 & 2 & 10 & 52 & 3 \\
\hline $\mathrm{pH}$ (units) & 37 & 6.4 & $6 . \overline{3}$ & $0 . \overline{1}$ & 0.6 & 7.7 & 5.0 \\
\hline \multicolumn{8}{|l|}{ Major ions (mg/L) } \\
\hline Calcium, dissolved & 15 & 0.58 & 0.33 & 0.11 & 0.43 & 1.5 & 0.10 \\
\hline Magnesium, dissolved & 15 & 0.09 & 0.10 & 0.02 & 0.06 & 0.24 & $<0.01$ \\
\hline Sodium, dissolved- & 15 & 0.5 & 0.4 & 0.1 & 0.3 & 1.2 & 0.2 \\
\hline Potassium, dissolved & 15 & 0.2 & 0.2 & 0.1 & 0.1 & 0.6 & 0.1 \\
\hline Alkalinity, total (as $\left.\mathrm{CaCO}_{3}\right)$ & 15 & 8 & 8 & 0 & 2 & 10 & 4 \\
\hline 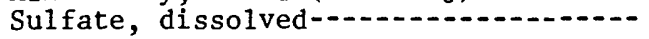 & 12 & 3.2 & $<5.0$ & 0.6 & $2 . \overline{2}$ & 5.0 & 0.6 \\
\hline Chloride, dissolved & 15 & 0.5 & 0.5 & 0.1 & 0.2 & 1.0 & 0.2 \\
\hline Silica, dissolved & 7 & 0.29 & 0.40 & 0.09 & 0.25 & 0.60 & 0.01 \\
\hline \multicolumn{8}{|l|}{ Nutrients (mg/L) } \\
\hline Nitrogen, nitrite, dissolved (as $\mathrm{N}$ )--- & 12 & 0.02 & $<0.02$ & 0.00 & 0.01 & 0.04 & $<0.02$ \\
\hline Nitrogen, nitrite plus nitrate, & & & & & & & \\
\hline dissolved (as $\mathrm{N}$ ) & 15 & 0.25 & 0.13 & 0.06 & 0.23 & 0.96 & $<0.09$ \\
\hline $\begin{array}{l}\text { Nitrogen, ammonia, dissolved (as N)--- } \\
\text { Nitrogen, ammonia plus organic }\end{array}$ & 12 & 0.66 & 0.62 & 0.09 & 0.32 & 1.3 & 0.19 \\
\hline dissolved (as N) & 14 & 1.4 & 1.1 & 0.26 & 0.97 & 4.0 & 0.59 \\
\hline Nitrogen, organic, dissolved (as N)-.- & 9 & 0.70 & 0.47 & 0.27 & 0.80 & 2.7 & 0.08 \\
\hline Nitrogen, dissolved (as $\mathrm{N}$ ) & 10 & 1.9 & 1.4 & 0.40 & 1.3 & 4.2 & 0.93 \\
\hline Phosphorus, dissolved (as P) & 15 & 0.08 & 0.05 & 0.02 & 0.08 & 0.28 & 0.01 \\
\hline Phosphorus, orthophosphate, & & & & & & & \\
\hline dissolved (as P) & 12 & 0.02 & 0.01 & 0.00 & 0.02 & 0.06 & $<0.01$ \\
\hline \multicolumn{8}{|l|}{ Metals $(\mu \mathrm{g} / \mathrm{L})$} \\
\hline 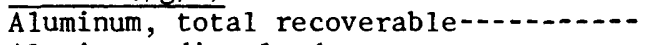 & 4 & 210 & 100 & 120 & 250 & 580 & 60 \\
\hline 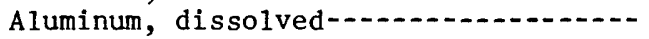 & 3 & 10 & 10 & 0 & 0 & 10 & $<10$ \\
\hline Arsenic, total & 7 & 1 & $<1$ & 0 & 0 & $<1$ & $<1$ \\
\hline Chromium, total recoverable-... & 4 & 1 & $<1$ & 0 & 0 & 1 & $<1$ \\
\hline Copper, total recoverable- & 4 & 6 & 6 & 2 & 4 & 12 & 1 \\
\hline Copper, dissolved- & 3 & 1 & 1 & 0 & 0 & 1 & $<\overline{1}$ \\
\hline Iron, total recoverable & 9 & 490 & 130 & 300 & 900 & 2,800 & 10 \\
\hline Iron, dissolved & 8 & 9 & 8 & 2 & 6 & 18 & $<3$ \\
\hline Lead, total recoverable & 15 & 11 & 7 & 3 & 12 & 51 & $<1$ \\
\hline Lead, dissolved- & 13 & 2 & 1 & 0 & 1 & 4 & $<1$ \\
\hline Manganese, total recoverable-.......... & 9 & 20 & 10 & 10 & 20 & 80 & $<10$ \\
\hline Manganese, dissolved & 8 & 5 & 2 & 2 & 7 & 21 & $<1$ \\
\hline Mercury, total recoverable & 7 & 0.1 & $<0 . \overline{1}$ & 0.0 & 0.0 & $0 . \overline{2}$ & $<0 . \overline{1}$ \\
\hline Nickel, total recoverable & 9 & 5 & 5 & 1 & 4 & 11 & $<1$ \\
\hline 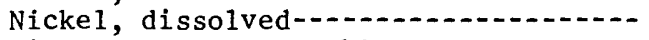 & 8 & 2 & 2 & 0 & 2 & 5 & $<1$ \\
\hline Zinc, total recoverable & 4 & 60 & 55 & 10 & 30 & 90 & 30 \\
\hline Zinc, dissolved & 3 & 24 & 22 & 5 & 9 & 34 & 17 \\
\hline \multicolumn{8}{|l|}{ OXYGEN DEMAND } \\
\hline \multicolumn{8}{|l|}{ Oygen demand, chemical, $0.25 \mathrm{~N}$} \\
\hline dichromate (mg/L) & 14 & 16 & 14 & 2 & 6 & 27 & $<10$ \\
\hline \multicolumn{8}{|l|}{ ORGANICS } \\
\hline \multicolumn{8}{|l|}{$\begin{array}{l}\text { Carbon, organic, dissolved } \\
\text { (mg/L as C) }\end{array}$} \\
\hline$(\mathrm{mg} / \mathrm{L}$ as $\mathrm{C})$ & 14 & 3.8 & 4.0 & 0.4 & 1.4 & 6.2 & 0.8 \\
\hline Phenols, total recoverable $\left(\mu_{g} / \mathrm{L}\right) \ldots$ & 10 & 5 & 4 & 1 & 4 & 15 & 2 \\
\hline
\end{tabular}


Table 6. Statistical summary of rainfall quality data: Industrial site-Continued

\begin{tabular}{|c|c|c|c|c|c|c|c|}
\hline Property or constituent & $\begin{array}{l}\text { Number } \\
\text { of } \\
\text { samples }\end{array}$ & Mean & Median & $\begin{array}{l}\text { Standard } \\
\text { error } \\
\text { of mean }\end{array}$ & $\begin{array}{l}\text { Standard } \\
\text { deviation }\end{array}$ & Maximum & Minimum \\
\hline \multicolumn{8}{|l|}{$\begin{array}{l}\text { ORGANICS--Cont inued } \\
\text { Pesticides (total recoverable, } \mu \mathrm{g} / \mathrm{L} \text { ) }\end{array}$} \\
\hline Chlordane- & 20 & 0.12 & $<0.10$ & 0.02 & 0.07 & 0.40 & $<0.10$ \\
\hline DDE-CD. & 20 & 0.01 & $<0.01$ & 0.00 & 0.00 & 0.02 & $<0.01$ \\
\hline Diazinon- & 21 & 0.18 & 0.14 & 0.04 & 0.21 & 0.93 & 0.01 \\
\hline Dieldrin- & 20 & 0.01 & $<0.01$ & 0.00 & 0.00 & 0.02 & $<0.01$ \\
\hline Endosulfan & 20 & 0.02 & $<0.01$ & 0.00 & 0.02 & 0.08 & $<0.01$ \\
\hline Lindane-1. & 20 & 0.02 & 0.01 & 0.00 & 0.01 & 0.04 & $<0.01$ \\
\hline Methoxych1or & 20 & 0.02 & $<0.01$ & 0.01 & 0.03 & 0.12 & $<0.01$ \\
\hline Malathion- & 21 & 0.03 & 0.02 & 0.01 & 0.03 & 0.11 & $<0.01$ \\
\hline Parathion- & 21 & 0.28 & 0.16 & 0.06 & 0.28 & 1.0 & $<0.01$ \\
\hline $2,4-D$ & 15 & 0.02 & $<0.01$ & 0.01 & 0.02 & 0.08 & $<0.01$ \\
\hline
\end{tabular}

Other pesticides analyzed but not detected

\begin{tabular}{|c|c|c|c|c|c|}
\hline $\begin{array}{c}\text { Pesticide } \\
\text { (total recoverable) }\end{array}$ & $\begin{array}{c}\text { Detection } \\
\text { limit } \\
(\mu \mathrm{g} / \mathrm{L})\end{array}$ & $\begin{array}{l}\text { Number } \\
\text { of } \\
\text { samples }\end{array}$ & $\begin{array}{c}\text { Pesticide } \\
\text { (total recoverable) }\end{array}$ & $\begin{array}{c}\text { Detection } \\
\text { limit } \\
(\mu g / L)\end{array}$ & $\begin{array}{l}\text { Number } \\
\text { of } \\
\text { samples }\end{array}$ \\
\hline Aldrin- & 0.01 & 20 & Methyl parathion- & 0.01 & 21 \\
\hline DDD-1 & 0.01 & 20 & Methyl trithion- & 0.01 & 21 \\
\hline DDT & 0.01 & 20 & Mirex & 0.01 & 20 \\
\hline Endrin- & 0.01 & 20 & Perthane-1..- & 0.1 & 20 \\
\hline Ethion- & 0.01 & 21 & Propham- & 2 & 5 \\
\hline Gross polychlorinated biphenyls-- & 0.01 & 20 & Sevin-- & 2 & 5 \\
\hline Gross polychlorinated & & & Silvex-1. & 0.01 & 15 \\
\hline naphthalenes & 0.1 & 20 & Toxaphene- & 1 & 20 \\
\hline Heptachlor & 0.01 & 20 & Trithion- & $0.0 \overline{1}$ & 21 \\
\hline Heptachlor epoxide & 0.01 & 20 & $2,4-D P-\ldots$ & 0.01 & 15 \\
\hline Me thomy 1- & 2 & 5 & $2,4,5-\mathrm{T} \cdots$ & 0.01 & 15 \\
\hline
\end{tabular}

Table 7. Statistical summary of rainfall quality data: Single-dwelling residential site

[Statistical calculations include analytical detection limit concentration for those analyses which are reported to be less than detection limit. Other pesticides were analyzed for but not detected and are given at the end of this table. <, actual value is less than value shown]

\begin{tabular}{|c|c|c|c|c|c|c|c|}
\hline Property or constituent & $\begin{array}{l}\text { Number } \\
\text { of } \\
\text { samples }\end{array}$ & Mean & Median & $\begin{array}{l}\text { St andard } \\
\text { error } \\
\text { of mean }\end{array}$ & $\begin{array}{l}\text { Standard } \\
\text { deviation }\end{array}$ & Maximum & Minimum \\
\hline \multicolumn{8}{|l|}{ INORGANICS } \\
\hline \multicolumn{8}{|l|}{ Field measurements } \\
\hline $\begin{array}{l}\text { Specific conductance }\left(\mu \mathrm{S} / \mathrm{cm} \text { at } 25^{\circ} \mathrm{C}\right)-- \\
\text { pH (units) }\end{array}$ & $\begin{array}{l}32 \\
33\end{array}$ & $\begin{array}{r}14 \\
5.9\end{array}$ & $\begin{array}{r}11 \\
5.8\end{array}$ & 0.2 & $\begin{array}{r}13 \\
0.8\end{array}$ & $\begin{array}{r}57 \\
7.7\end{array}$ & $\begin{array}{r}2 \\
4.7\end{array}$ \\
\hline \multicolumn{8}{|l|}{ Major ions (mg/L) } \\
\hline Calcium, dissolved & 16 & 0.48 & 0.46 & 0.08 & 0.31 & 1.3 & 0.14 \\
\hline Magnesium, dissolved & 16 & 0.08 & 0.10 & 0.01 & 0.05 & 0.18 & $<0.01$ \\
\hline Sodium, dissolved & 16 & 0.5 & 0.5 & 0.1 & 0.2 & 1.1 & $<0.2$ \\
\hline Potassium, dissolved- & 16 & 0.1 & 0.1 & 0.0 & 0.1 & 0.3 & $<0.1$ \\
\hline
\end{tabular}


Table 7. Statistical summary of rainfall quality data: Single-dwelling residential site-Continued

\begin{tabular}{|c|c|c|c|c|c|c|c|}
\hline Property or constituent & $\begin{array}{c}\text { Number } \\
\text { of } \\
\text { samples }\end{array}$ & Mean & Median & $\begin{array}{c}\text { Standard } \\
\text { error } \\
\text { of mean }\end{array}$ & $\begin{array}{l}\text { Standard } \\
\text { deviation }\end{array}$ & Maximum & Minimum \\
\hline \multicolumn{8}{|l|}{ INORGANICS--Continued } \\
\hline Alkalinity, total (as $\left.\mathrm{CaCO}_{3}\right)$ & 16 & 7 & 7 & 0 & 2 & 9 & 3 \\
\hline Sulfate, díssolved & 14 & 3.4 & 5.0 & 0.6 & 2.2 & 5.0 & 0.5 \\
\hline Chloride, dissolved & 16 & 0.5 & 0.4 & 0.1 & 0.3 & 1.2 & 0.1 \\
\hline Silica, dissolved & 8 & 0.25 & 0.24 & 0.09 & 0.25 & 0.60 & $<0.01$ \\
\hline \multicolumn{8}{|l|}{ Nutrients $(\mathrm{mg} / \mathrm{L})$} \\
\hline $\begin{array}{l}\text { Nitrogen, nitrite, dissolved (as N)--- } \\
\text { Nitrogen, nitrite plus nitrate, }\end{array}$ & 13 & 0.02 & $<0.02$ & 0.00 & 0.01 & 0.04 & $<0.02$ \\
\hline dissolved (as N) & 16 & 0.22 & 0.13 & 0.04 & 0.17 & 0.60 & 0.04 \\
\hline $\begin{array}{l}\text { Nitrogen, ammonia, dissolved (as N) --- } \\
\text { Nitrogen, ammonia plus organic, }\end{array}$ & 13 & 0.37 & 0.35 & 0.06 & 0.22 & 0.74 & 0.11 \\
\hline dissolved (as N) & 14 & 1.4 & 0.70 & 0.64 & 2.4 & 9.7 & 0.30 \\
\hline Nitrogen, organic, dissolved (as $\mathrm{N}$ )--- & 10 & 0.43 & 0.35 & 0.08 & 0.24 & 0.99 & 0.10 \\
\hline Nitrogen, dissolved (as N) & 10 & 2.0 & 1.1 & 0.90 & 2.8 & 10 & 0.40 \\
\hline Phosphorus, dissolved (as N) & 16 & 0.03 & 0.01 & 0.01 & 0.04 & 0.14 & $<0.01$ \\
\hline dissolved (as P) & 13 & 0.01 & 0.01 & 0.00 & 0.01 & 0.04 & $<0.01$ \\
\hline \multicolumn{8}{|l|}{ Metals $(\mu \mathrm{g} / \mathrm{L})$} \\
\hline Aluminum, total recoverable............ & 3 & 50 & 50 & 10 & 20 & 80 & 30 \\
\hline Aluminum, dissolved & 3 & 20 & 10 & 10 & 10 & 30 & $<10$ \\
\hline Arsenic, total- & 7 & 1 & $<1$ & 0 & 0 & $<1$ & $<1$ \\
\hline Chromium, total recoverable & 3 & 1 & $<1$ & 0 & 0 & $<1$ & $<1$ \\
\hline Copper, total recoverable- & 3 & 4 & 4 & 1 & 2 & 6 & $<1$ \\
\hline Copper, dissolved & 3 & 2 & 1 & 1 & 1 & 3 & 1 \\
\hline Iron, total recoverable & 9 & 330 & 90 & 160 & 470 & 1,400 & 10 \\
\hline Iron, dissolved- & 8 & 8 & 4 & 3 & 8 & 24 & $<3$ \\
\hline Lead, total recoverable & 16 & 12 & 8 & 4 & 14 & 61 & $<1$ \\
\hline Lead, dissolved & 14 & 2 & 1 & 1 & 3 & 11 & $<1$ \\
\hline Manganese, total recoverable & 9 & 20 & 10 & 10 & 20 & 60 & $<10$ \\
\hline Manganese, dissolved & 8 & 4 & 2 & 2 & 5 & 17 & $<1$ \\
\hline Mercury, total recoverable & 7 & 0.1 & 0.1 & 0.0 & 0.0 & 0.1 & $<0.1$ \\
\hline Nickel, total recoverable- & 9 & 7 & 5 & 1 & 4 & 12 & $<1$ \\
\hline Nickel, dissolved- & 8 & 2 & 2 & 0 & 1 & 3 & $<1$ \\
\hline Zinc, total recoverable & 3 & 50 & 60 & 10 & 20 & 60 & 30 \\
\hline Zinc, dissolved-... & 3 & 32 & 31 & 1 & 2 & 34 & 30 \\
\hline \multicolumn{8}{|l|}{ OXYGEN DEMAND } \\
\hline Oxygen demand, chemical, $0.25 \mathrm{~N}$ & & & & & & & \\
\hline dichromate $(\mathrm{mg} / \mathrm{L})$ & 15 & 14 & 12 & 2 & 6 & 30 & $<7$ \\
\hline \multicolumn{8}{|l|}{ ORGANICS } \\
\hline $\begin{array}{l}\text { Carbon, organic, dissolved } \\
\text { (mg/L as C) }\end{array}$ & & 36 & 3 & & & & \\
\hline Phenols, total recoverable $(\mu g / \mathrm{L})$ & 13 & $\begin{array}{r}3.6 \\
8\end{array}$ & $\begin{array}{r}3.3 \\
8\end{array}$ & $\begin{array}{r}0.4 \\
2\end{array}$ & $\begin{array}{r}1.4 \\
6\end{array}$ & $\begin{array}{r}6.2 \\
25\end{array}$ & $\begin{array}{r}2.1 \\
1\end{array}$ \\
\hline \multicolumn{8}{|l|}{ Pesticides (total recoverable, $\mu \mathrm{g} / \mathrm{L}$ ) } \\
\hline 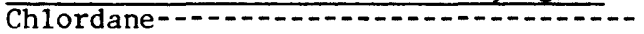 & 20 & 0.12 & $<0.10$ & 0.02 & 0.07 & 0.40 & $<0.10$ \\
\hline Diazinon- & 20 & 0.12 & 0.08 & 0.02 & 0.11 & 0.42 & 0.02 \\
\hline Endosulfan- & 20 & 0.01 & $<0.01$ & 0.00 & 0.01 & 0.04 & $<0.01$ \\
\hline Lindane- & 20 & 0.01 & 0.01 & 0.00 & 0.00 & 0.02 & $<0.01$ \\
\hline Malathion- & 20 & 0.03 & 0.03 & 0.01 & 0.03 & 0.11 & $<0.01$ \\
\hline Methoxychlor & 20 & 0.01 & $<0.01$ & 0.00 & 0.01 & 0.05 & $<0.01$ \\
\hline Parathion- & 20 & 0.23 & 0.20 & 0.06 & 0.26 & 0.86 & $<0.01$ \\
\hline $2,4-D+\cdots$ & 20 & 0.02 & $<0.01$ & 0.00 & 0.01 & 0.04 & $<0.01$ \\
\hline
\end{tabular}


Table 7. Statistical summary of rainfall quality data: Single-dwelling residential site-Continued

Other pesticides analyzed but not detected

\begin{tabular}{|c|c|c|c|c|c|}
\hline $\begin{array}{c}\text { Pesticide } \\
\text { (total recoverable) }\end{array}$ & $\begin{array}{c}\text { Detection } \\
\text { limit } \\
\left(\mu_{g} / L\right)\end{array}$ & $\begin{array}{l}\text { Number } \\
\text { of } \\
\text { samples }\end{array}$ & $\begin{array}{c}\text { Pesticide } \\
\text { (total recoverable) }\end{array}$ & $\begin{array}{l}\text { Detection } \\
\text { limit } \\
(\mu g / L)\end{array}$ & $\begin{array}{l}\text { Number } \\
\text { of } \\
\text { samples }\end{array}$ \\
\hline Aldrin- & 0.01 & 20 & Methomyl- & 2 & 5 \\
\hline 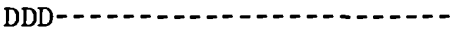 & 0.01 & 20 & Methyl parathion- & 0.01 & $\star 20$ \\
\hline DDE- & 0.01 & $\star * 20$ & 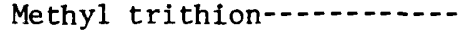 & 0.01 & 20 \\
\hline DDT-10 & 0.01 & 20 & Mirex-1 & 0.01 & 20 \\
\hline Dieldrin- & 0.01 & $* 20$ & Perthane-1. & 0.1 & 20 \\
\hline Endrin- & 0.01 & 20 & Propham- & 2 & 5 \\
\hline Ethion- & 0.01 & 20 & Sevin- & 2 & 5 \\
\hline Gross polychlorinated & & & Silvex-1. & 0.01 & 20 \\
\hline biphenyls- & 0.1 & 20 & Toxaphene-- & 1 & 20 \\
\hline Gross polychlorinated & & & Trithion- & 0.01 & 20 \\
\hline 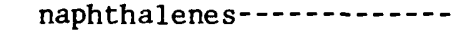 & 0.1 & 20 & $2,4-D P \ldots$ & 0.01 & 20 \\
\hline Heptachlor & 0.01 & 20 & $2,4,5-\mathrm{T} \cdots$ & 0.01 & 20 \\
\hline Heptachlor epoxide........... & 0.01 & 20 & & & \\
\hline
\end{tabular}

* One sample was equal to the detection limit.

**Three samples were equal to the detection limit.

Table 8. Statistical summary of rainfall quality data: Laboratory site

[Statistical calculations include analytical detection limit concentration for those analyses which are reported to be less than detection limit. Other pesticides were analyzed for but not detected and are given at the end of this table. ., no data available. <, actual value is less than value shown]

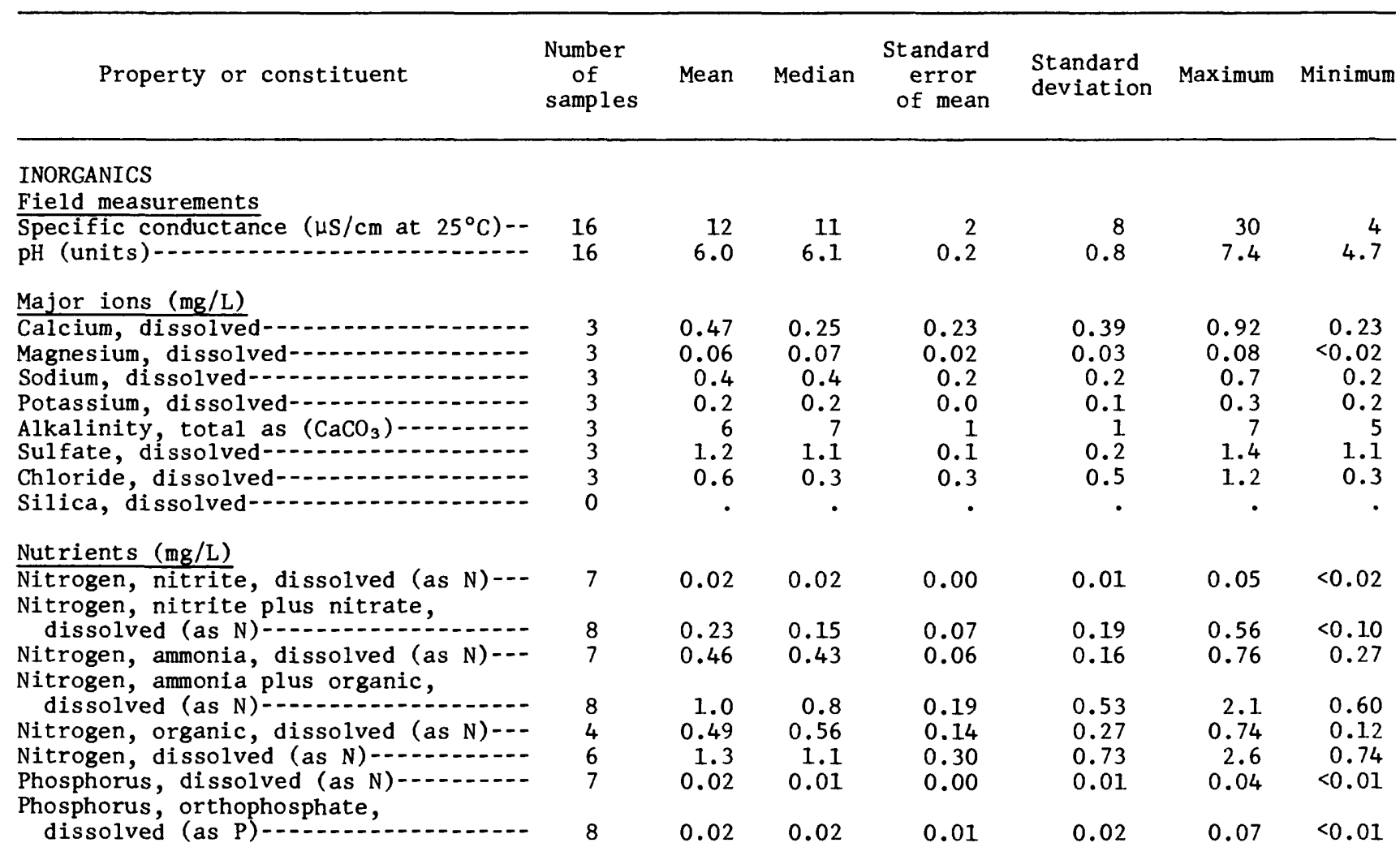


Table 8. Statistical summary of rainfall quality data: Laboratory site-Continued

\begin{tabular}{|c|c|c|c|c|c|c|c|}
\hline Property or constituent & $\begin{array}{l}\text { Number } \\
\text { of } \\
\text { samples }\end{array}$ & Mean & Median & $\begin{array}{c}\text { Standard } \\
\text { error } \\
\text { of mean }\end{array}$ & $\begin{array}{l}\text { Standard } \\
\text { deviation }\end{array}$ & Maximum & Minimum \\
\hline \multicolumn{8}{|l|}{ INORGANICS--Continued } \\
\hline Aluminum, total recoverable & 3 & 80 & 80 & 9 & 20 & 90 & 60 \\
\hline Aluminum, dissolved & 3 & 10 & $<10$ & 3 & 6 & 20 & $<10$ \\
\hline Arsenic, total & 5 & 1 & $<1$ & 0 & 0 & 1 & $<1$ \\
\hline Chromium, total recoverable-..... & 3 & 1 & $<\overline{1}$ & 0 & 0 & $<1$ & $<1$ \\
\hline Copper, total recoverable- & 3 & 4 & 2 & 2 & 3 & 8 & $<2$ \\
\hline Copper, dissolved & 3 & 1 & 1 & 0 & 1 & 2 & 1 \\
\hline Iron, total recoverable & 6 & 460 & 80 & 250 & 610 & 1,300 & 40 \\
\hline Iron, dissolved & 6 & 12 & 10 & 4 & 10 & 30 & $<3$ \\
\hline Lead, total recoverable & 6 & 11 & 5 & 7 & 16 & 44 & 2 \\
\hline Lead, dissolved & 6 & 2 & 1 & 1 & 2 & 6 & $<1$ \\
\hline Manganese, total recoverable & 6 & 20 & 10 & $\overline{0}$ & 10 & 40 & $<10$ \\
\hline 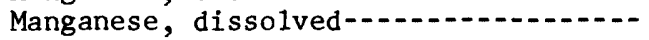 & 6 & 6 & 7 & 2 & 4 & 10 & 1 \\
\hline Mercury, total recoverable & 5 & 0.1 & $<0.1$ & 0.0 & 0.0 & 0.1 & $<0.1$ \\
\hline Nickel, total recoverable & 6 & 5 & 5 & 1 & 3 & 9 & 2 \\
\hline Nicke1, dissolved & 6 & 2 & 3 & 0 & 1 & 4 & 1 \\
\hline Zinc, total recoverable-.. & 3 & 20 & 20 & 0 & 10 & 30 & 20 \\
\hline Zinc, dissolved- & 3 & 19 & 17 & 4 & 6 & 26 & 14 \\
\hline \\
\hline $\begin{array}{l}\text { Oxygen demand, chemical, } 0.25 \mathrm{~N} \\
\text { dichromate }(\mathrm{mg} / \mathrm{L})\end{array}$ & 5 & 16 & 16 & 2 & 5 & 23 & $<10$ \\
\hline \multicolumn{8}{|l|}{ ORGANICS } \\
\hline \multicolumn{8}{|l|}{ Carbon, organic, dissolved } \\
\hline Phenols, total recoverable $(\mu \mathrm{g} / \mathrm{L}) \ldots$ & 10 & $\begin{array}{r}6.9 \\
7\end{array}$ & $\begin{array}{r}5.9 \\
6\end{array}$ & $\begin{array}{r}1.7 \\
1\end{array}$ & $\begin{array}{r}4.4 \\
4\end{array}$ & $\begin{array}{r}16.0 \\
14\end{array}$ & $\begin{array}{r}1.8 \\
2\end{array}$ \\
\hline \multicolumn{8}{|l|}{ Pesticides (total recoverable, $\mu \mathrm{g} / \mathrm{L}$ ) } \\
\hline Chlordane--no & 10 & 0.10 & $<0.10$ & 0.00 & 0.00 & $<0.10$ & $<0.10$ \\
\hline DDE- $-2-1$ & 10 & 0.01 & $<0.01$ & 0.00 & 0.00 & 0.02 & $<0.01$ \\
\hline Diazinon- & 13 & 0.13 & 0.11 & 0.02 & 0.07 & 0.26 & 0.03 \\
\hline Endosulfan- & 10 & 0.02 & $<0.01$ & 0.01 & 0.02 & 0.07 & $<0.01$ \\
\hline Lindane- -1 & 10 & 0.01 & 0.01 & 0.00 & 0.00 & 0.01 & $<0.01$ \\
\hline Malathion- & 13 & 0.04 & 0.03 & 0.01 & 0.03 & 0.10 & 0.01 \\
\hline Methoxychlor & 10 & 0.01 & $<0.01$ & 0.00 & 0.01 & 0.04 & $<0.01$ \\
\hline Parathion & 13 & 0.19 & 0.16 & 0.05 & 0.19 & 0.66 & $<0.01$ \\
\hline 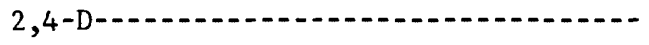 & 9 & 0.01 & $<0.01$ & 0.00 & 0.01 & 0.04 & $<0.01$ \\
\hline
\end{tabular}

Other pesticides analyzed but not detected

\begin{tabular}{|c|c|c|c|c|c|}
\hline $\begin{array}{c}\text { Pesticide } \\
\text { (total recoverable) }\end{array}$ & $\begin{array}{l}\text { Detection } \\
\text { limit } \\
(\mu g / L)\end{array}$ & $\begin{array}{l}\text { Number } \\
\text { of } \\
\text { samples }\end{array}$ & $\begin{array}{c}\text { Pesticide } \\
\text { (total recoverable) }\end{array}$ & $\begin{array}{l}\text { Detection } \\
\text { limit } \\
(\mu g / L)\end{array}$ & $\begin{array}{l}\text { Number } \\
\text { of } \\
\text { samples }\end{array}$ \\
\hline $\begin{array}{l}\text { Aldrin } \\
\text { DDDD } \\
\text { DDT } \\
\text { Dieldrin } \\
\text { Endrin } \\
\text { Ethion } \\
\text { Gross polychlorinated } \\
\text { biphenyls } \\
\text { Gross polychlorinated } \\
\text { naphthalenes } \\
\text { Heptachlor }\end{array}$ & $\begin{array}{l}0.01 \\
0.01 \\
0.01 \\
0.01 \\
0.01 \\
0.01 \\
0.1 \\
0.1 \\
0.01\end{array}$ & $\begin{array}{r}10 \\
10 \\
10 \\
* 10 \\
10 \\
* 13 \\
10 \\
10 \\
10\end{array}$ & $\begin{array}{l}\text { Heptachlor epoxide } \\
\text { Methy1 parathion } \\
\text { Methyl trithion } \\
\text { Mirex } \\
\text { Perthane } \\
\text { Silvex } \\
\text { Toxaphene } \\
\text { Trithion } \\
\text { 2,4-DP } \\
2,4,5-\mathrm{T}\end{array}$ & $\begin{array}{r}0.01 \\
0.01 \\
0.01 \\
0.01 \\
0.1 \\
0.01 \\
1 \\
0.01 \\
0.01 \\
0.01\end{array}$ & $\begin{array}{r}10 \\
* 13 \\
13 \\
10 \\
10 \\
9 \\
10 \\
13 \\
9 \\
9\end{array}$ \\
\hline
\end{tabular}

$\star$ One sample was equal to the detection limit. 
Table 9. Results of statistical comparison testing between sites for composite rainfall quality samples

[Comparison testing includes only those constituents that were consistently above analytical detection levels. 1, statistically similar at 0.05 -significance

level; 2, statistically different at 0.05-significance level; 3 , no test performed due to significant difference between years for these constituents at the industrial site; 4, no test performed (no silica data for laboratory site)]

\begin{tabular}{|c|c|c|c|}
\hline \multirow[b]{2}{*}{ Property or constituent } & \multicolumn{3}{|c|}{ Sites compared } \\
\hline & $\begin{array}{l}\text { Industrial/ } \\
\text { Single }\end{array}$ & $\begin{array}{l}\text { Industrial/ } \\
\text { Laboratory }\end{array}$ & $\begin{array}{c}\text { Single/ } \\
\text { Laboratory }\end{array}$ \\
\hline 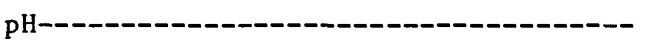 & 2 & 1 & 1 \\
\hline Specific conductance---- & 1 & 1 & 1 \\
\hline Ca1cium, dissolved-_- & 1 & 1 & 1 \\
\hline Magnesium, dissolved--_---_---_- & 1 & 1 & 1 \\
\hline Sodium, dissolved-- & 1 & 1 & 1 \\
\hline Potassium, dissolved--_---_- & 2 & 1 & 2 \\
\hline Sulfate, dissolved- & 1 & 1 & 1 \\
\hline Chloride, dissolved-_- & 1 & 1 & 1 \\
\hline Silica, dissolved-- & 1 & 4 & 4 \\
\hline $\begin{array}{l}\text { Nitrogen, nitrite, dissolved (as N)--- } \\
\text { Nitrogen, nitrite plus nitrate, }\end{array}$ & 1 & 1 & 1 \\
\hline dissolved (as N) - & 1 & 1 & 1 \\
\hline $\begin{array}{l}\text { Nitrogen, ammonia, dissolved (as } \mathrm{N})--- \\
\text { Nitrogen, ammonia plus organic, }\end{array}$ & 2 & 1 & 1 \\
\hline dissolved (as N) - & 2 & 1 & 1 \\
\hline Phosphorus, dissolved (as P) & 3 & 3 & 1 \\
\hline Aluminum, total recoverable------- & 1 & 1 & 1 \\
\hline Copper, total recoverable- & 1 & 1 & 1 \\
\hline Iron, total recoverable- & 1 & 1 & 1 \\
\hline Lead, total recoverable- & 1 & 1 & 1 \\
\hline Lead, dissolved-n & 1 & 1 & 1 \\
\hline Manganese, total recoverable-C & 1 & 1 & 1 \\
\hline Manganese, dissolved & 1 & 1 & 1 \\
\hline Nickel, total recoverable- & 1 & 1 & 1 \\
\hline Zinc, total recoverable-n & 1 & 1 & 1 \\
\hline Zinc, dissolved-n- & 1 & 1 & 2 \\
\hline \multicolumn{4}{|l|}{ Oxygen demand, chemical, } \\
\hline $0.25 \mathrm{~N}$ dichromate- & 1 & 1 & 1 \\
\hline Carbon, organic, dissolved- & 3 & 3 & 2 \\
\hline Phenols, total recoverable- & 2 & 1 & 1 \\
\hline
\end{tabular}


Table 10. Rainfall constituent event mean concentrations and loads for storms monitored at industrial site

[Event mean concentrations, in milligrams per liter (mg/L) or micrograms per liter ( $\mu g / \mathrm{L})$; storm load, in pounds (1b). ., no data available. <, actual value is less than value shown]

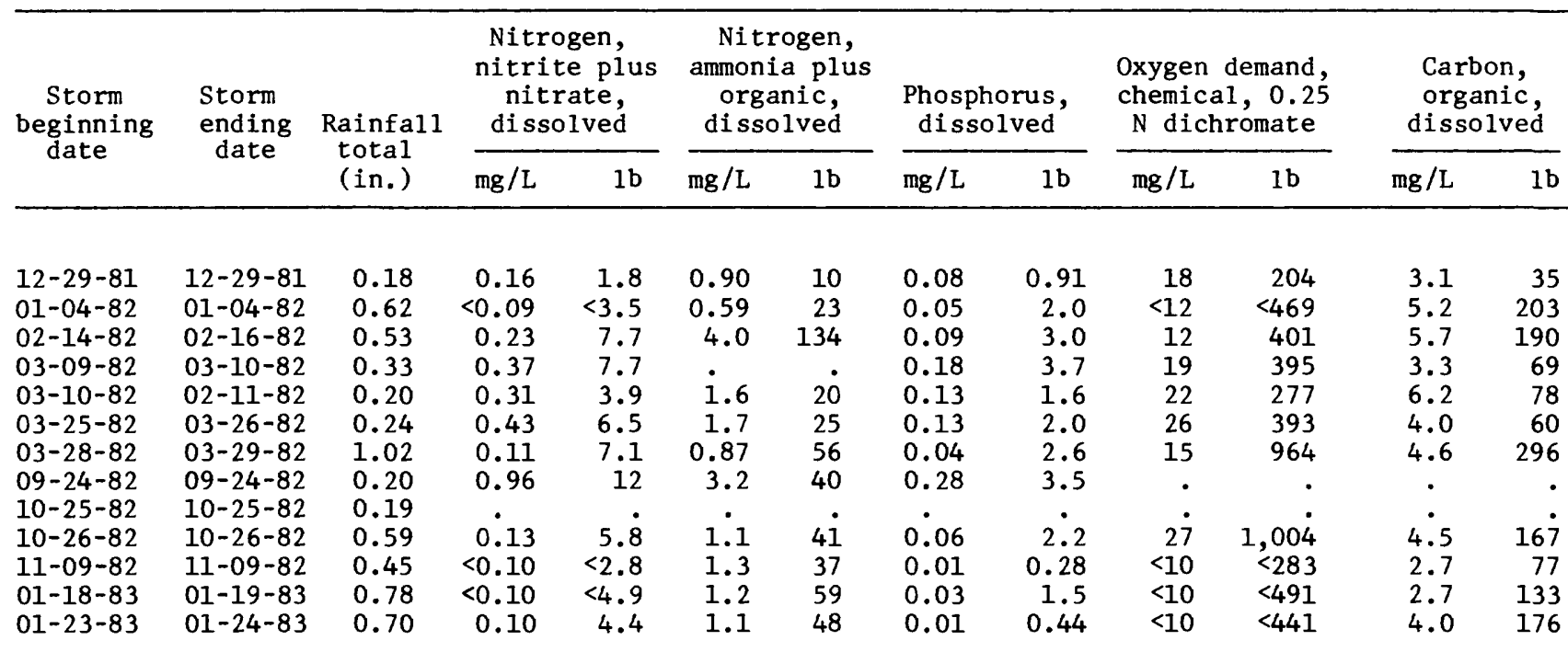

\begin{tabular}{|c|c|c|c|c|c|c|c|c|c|c|c|c|}
\hline \multirow{2}{*}{$\begin{array}{l}\text { Storm } \\
\text { beginning } \\
\text { date }\end{array}$} & \multirow{2}{*}{$\begin{array}{l}\text { Storm } \\
\text { ending } \\
\text { date }\end{array}$} & \multirow{2}{*}{$\begin{array}{l}\text { Rainfall } \\
\text { total } \\
\text { (in.) }\end{array}$} & \multicolumn{2}{|c|}{$\begin{array}{l}\text { Aluminum, } \\
\text { total } \\
\text { recoverable }\end{array}$} & \multicolumn{2}{|c|}{$\begin{array}{l}\text { Arsenic, } \\
\text { total }\end{array}$} & \multicolumn{2}{|c|}{$\begin{array}{l}\text { Chromium, } \\
\text { total } \\
\text { recoverable }\end{array}$} & \multicolumn{2}{|c|}{$\begin{array}{c}\text { Copper, } \\
\text { total } \\
\text { recoverable }\end{array}$} & \multicolumn{2}{|c|}{$\begin{array}{c}\text { Iron, } \\
\text { total } \\
\text { recoverable }\end{array}$} \\
\hline & & & $\mu \mathrm{g} / \mathrm{L}$ & $1 b$ & $\mu \mathrm{g} / \mathrm{L}$ & $1 b$ & $\mu_{\mathrm{g}} / \mathrm{L}$ & $1 b$ & $\mu g / L$ & $1 b$ & $\mu g / L$ & $1 b$ \\
\hline
\end{tabular}

\begin{tabular}{|c|c|c|c|c|c|c|c|c|c|c|c|c|}
\hline $\begin{array}{l}12-29-81 \\
01-04-82 \\
02-14-82 \\
03-09-82 \\
03-10-82 \\
03-25-82 \\
03-28-82 \\
09-24-82 \\
10-25-82 \\
10-26-82 \\
11-09-82 \\
01-18-83 \\
01-23-83\end{array}$ & $\begin{array}{l}12-29-81 \\
01-04-82 \\
02-16-82 \\
03-10-82 \\
03-11-82 \\
03-26-82 \\
03-29-82 \\
09-24-82 \\
10-25-82 \\
10-26-82 \\
11-09-82 \\
01-19-83 \\
01-04-83\end{array}$ & $\begin{array}{l}0.18 \\
0.62 \\
0.53 \\
0.33 \\
0.20 \\
0.24 \\
1.02 \\
0.20 \\
0.19 \\
0.59 \\
0.45 \\
0.78 \\
0.70\end{array}$ & $\begin{array}{r}\dot{ } \\
\dot{ } \\
\dot{ } \\
580 \\
140 \\
60 \\
.\end{array}$ & $\begin{array}{c}\dot{ } \\
\dot{0} \\
\dot{ } \\
\dot{0} \\
6.9 \\
4.0 \\
3.0 \\
.\end{array}$ & $\begin{array}{l}\dot{ } \\
\dot{ } \\
\dot{ } \\
: \\
\dot{ } \\
<1 \\
<1 \\
<1\end{array}$ & $\begin{array}{c}\dot{.} \\
\dot{.} \\
\dot{.} \\
<0.04 \\
<0.03 \\
<0.05 \\
<0.04\end{array}$ & $\begin{array}{r}\dot{ } \\
\dot{ } \\
\dot{ } \\
\dot{ } \\
\dot{1} \\
<1 \\
<1 \\
\text {. }\end{array}$ & $\begin{array}{c}\dot{.} \\
\dot{.} \\
\dot{0} \\
0.01 \\
<0.03 \\
<0.05 \\
.\end{array}$ & $\begin{array}{r}\dot{ } \\
\dot{.} \\
\dot{ } \\
\dot{ } \\
12 \\
\dot{6} \\
6 \\
.\end{array}$ & $\begin{array}{c}\dot{ } \\
\dot{0} \\
\dot{0} \\
0.14 \\
0.17 \\
0.30 \\
\dot{0}\end{array}$ & $\begin{array}{r}\dot{ } \\
\dot{.} \\
\dot{ } \\
2,800 \\
830 \\
40 \\
350 \\
60 \\
10\end{array}$ & $\begin{array}{r}\dot{ } \\
\dot{ } \\
\dot{ } \\
\dot{3} \\
9.9 \\
1.5 \\
9.9 \\
3.0 \\
0.44\end{array}$ \\
\hline \multirow{2}{*}{$\begin{array}{c}\text { Storm } \\
\text { beginning } \\
\text { date }\end{array}$} & \multirow{2}{*}{$\begin{array}{l}\text { Storm } \\
\text { ending } \\
\text { date }\end{array}$} & \multirow{2}{*}{$\begin{array}{l}\text { Rainfall } \\
\text { total } \\
\text { (in.) }\end{array}$} & \multicolumn{2}{|c|}{$\begin{array}{c}\text { Lead, } \\
\text { total } \\
\text { recoverable }\end{array}$} & \multicolumn{2}{|c|}{$\begin{array}{l}\text { Manganese, } \\
\text { total } \\
\text { recoverable }\end{array}$} & \multicolumn{2}{|c|}{$\begin{array}{c}\text { Mercury, } \\
\text { total } \\
\text { recoverable }\end{array}$} & \multicolumn{2}{|c|}{$\begin{array}{c}\text { Nickel, } \\
\text { total } \\
\text { recoverable }\end{array}$} & \multicolumn{2}{|c|}{$\begin{array}{l}\text { Zinc, } \\
\text { total } \\
\text { recoverable }\end{array}$} \\
\hline & & & $\mu \mathrm{g} / \mathrm{L}$ & $1 b$ & $\mu g / L$ & $1 b$ & $\mu \mathrm{g} / \mathrm{L}$ & $1 \mathrm{~b}$ & $\mu_{g} / L$ & $1 b$ & $\mu g / L$ & $1 b$ \\
\hline $\begin{array}{l}12-29-81 \\
01-04-82 \\
02-14-82 \\
03-09-82 \\
03-10-82 \\
03-25-82 \\
03-28-82 \\
09-24-82 \\
10-25-82 \\
10-26-82 \\
11-09-82 \\
01-18-83 \\
01-23-83\end{array}$ & $\begin{array}{l}12-29-81 \\
01-04-82 \\
02-16-82 \\
03-10-82 \\
03-11-82 \\
03-26-82 \\
03-29-82 \\
09-24-82 \\
10-25-82 \\
10-26-82 \\
11-09-82 \\
01-19-83 \\
01-24-83\end{array}$ & $\begin{array}{l}0.18 \\
0.62 \\
0.53 \\
0.33 \\
0.20 \\
0.24 \\
1.02 \\
0.20 \\
0.19 \\
0.59 \\
0.45 \\
0.78 \\
0.70\end{array}$ & $\begin{array}{r}7 \\
7 \\
8 \\
8 \\
5 \\
13 \\
10 \\
51 \\
16 \\
4 \\
8 \\
2 \\
2\end{array}$ & $\begin{array}{l}0.27 \\
0.67 \\
0.17 \\
0.06 \\
0.20 \\
0.64 \\
0.64 \\
0.19 \\
0.15 \\
0.23 \\
0.10 \\
0.09\end{array}$ & $\begin{array}{r}: \\
: \\
: \\
80 \\
40 \\
<10 \\
10 \\
<10 \\
<10\end{array}$ & $\begin{array}{r}\dot{ } \\
\dot{.} \\
\dot{ } \\
i .0 \\
0.48 \\
<0.37 \\
0.28 \\
<0.49 \\
<0.44\end{array}$ & $\begin{array}{c}: \\
\vdots \\
\vdots \\
\vdots \\
<0.1 \\
0.1 \\
0.2 \\
<0.1\end{array}$ & $\begin{array}{r}\dot{ } \\
\dot{0} \\
\dot{0} \\
\dot{0} \\
<0.01 \\
<0.01 \\
0.01 \\
<0.01\end{array}$ & $\begin{array}{r}\dot{ } \\
\dot{ } \\
\dot{ } \\
\dot{ } \\
11 \\
3 \\
5 \\
10 \\
<1 \\
1\end{array}$ & $\begin{array}{c}\dot{ } \\
\dot{ } \\
\dot{ } \\
\dot{0} \\
0.14 \\
0.04 \\
0.19 \\
0.28 \\
<0.05 \\
0.04\end{array}$ & $\begin{array}{r}\dot{ } \\
\dot{ } \\
\dot{ } \\
\dot{ } \\
90 \\
70 \\
40\end{array}$ & $\begin{array}{c}\dot{ } \\
\dot{ } \\
\dot{ } \\
\dot{ } \\
1.1 \\
2.0 \\
2.0 \\
.\end{array}$ \\
\hline
\end{tabular}


Table 11. Rainfall constituent event mean concentrations and loads for storms monitored at single-dwelling residential site

[Event mean concentrations, in milligrams per liter (mg/L) or micrograms per liter ( $\mu \mathrm{g} / \mathrm{L})$; storm load, in pounds (1b). ., no data available. <, actual value is less than value shown]

\begin{tabular}{|c|c|c|c|c|c|c|c|c|c|c|c|c|}
\hline \multirow{2}{*}{$\begin{array}{l}\text { Storm } \\
\text { beginning } \\
\text { date }\end{array}$} & \multirow{2}{*}{$\begin{array}{l}\text { Storm } \\
\text { ending } \\
\text { date }\end{array}$} & \multirow{2}{*}{$\begin{array}{l}\text { Rainfall } \\
\text { total } \\
\text { (in.) }\end{array}$} & \multicolumn{2}{|c|}{$\begin{array}{l}\text { Nitrogen, } \\
\text { nitrite plus } \\
\text { nitrate, } \\
\text { dissolved }\end{array}$} & \multicolumn{2}{|c|}{$\begin{array}{l}\text { Nitrogen, } \\
\text { ammonia plus } \\
\text { organic, } \\
\text { dissolved }\end{array}$} & \multicolumn{2}{|c|}{$\begin{array}{l}\text { Phosphorus, } \\
\text { dissolved }\end{array}$} & \multicolumn{2}{|c|}{$\begin{array}{l}\text { Oxygen demand, } \\
\text { chemical, } 0.25 \\
\mathrm{~N} \text { dichromate }\end{array}$} & \multicolumn{2}{|c|}{$\begin{array}{l}\text { Carbon, } \\
\text { organic, } \\
\text { dissolved }\end{array}$} \\
\hline & & & $\mathrm{mg} / \mathrm{L}$ & $1 b$ & $\mathrm{mg} / \mathrm{L}$ & $1 b$ & $\mathrm{mg} / \mathrm{L}$ & $1 b$ & $\mathrm{mg} / \mathrm{L}$ & $1 b$ & $\mathrm{mg} / \mathrm{L}$ & $1 b$ \\
\hline $\begin{array}{l}12-29-81 \\
01-04-82 \\
02-14-82 \\
03-09-82 \\
03-10-82 \\
03-25-82 \\
03-28-82 \\
03-31-82 \\
09-24-82 \\
10-25-82 \\
10-26-82 \\
11-09-82 \\
01-18-83 \\
01-24-83 \\
02-28-83 \\
03-16-83 \\
03-23-83\end{array}$ & $\begin{array}{l}12-30-81 \\
01-04-82 \\
02-16-82 \\
03-10-82 \\
03-11-82 \\
03-26-82 \\
03-29-82 \\
03-31-82 \\
09-24-82 \\
10-25-82 \\
10-26-82 \\
11-09-82 \\
01-19-83 \\
01-24-83 \\
03-01-83 \\
03-16-83 \\
03-23-83\end{array}$ & $\begin{array}{l}0.38 \\
0.83 \\
0.65 \\
0.47 \\
0.30 \\
0.20 \\
0.45 \\
0.95 \\
0.22 \\
0.09 \\
0.69 \\
0.45 \\
0.85 \\
0.74 \\
1.1 \\
0.40 \\
0.57\end{array}$ & $\begin{array}{r}0.14 \\
<0.09 \\
0.17 \\
0.46 \\
0.25 \\
0.45 \\
0.17 \\
0.04 \\
0.60 \\
.1 \\
0.10 \\
0.12 \\
<0.10 \\
<0.10 \\
<0.10 \\
0.46 \\
0.10\end{array}$ & $\begin{array}{r}1.1 \\
<1.6 \\
2.4 \\
4.6 \\
1.6 \\
1.9 \\
1.6 \\
0.81 \\
2.8 \\
.0 \\
1.5 \\
1.2 \\
<1.8 \\
<1.6 \\
<2.4 \\
3.9 \\
1.2\end{array}$ & $\begin{array}{c}0.68 \\
0.53 \\
1.7 \\
\dot{9} .7 \\
1.3 \\
0.92 \\
0.36 \\
\dot{1} \\
\dot{1} .0 \\
0.90 \\
0.70 \\
0.30 \\
0.50 \\
0.70 \\
0.60\end{array}$ & $\begin{array}{r}5.5 \\
9.4 \\
24 \\
. \\
62 \\
5.5 \\
8.8 \\
7.3 \\
\vdots \\
15 \\
8.6 \\
13 \\
4.7 \\
12 \\
6.0 \\
7.3\end{array}$ & $\begin{array}{r}0.02 \\
0.01 \\
0.08 \\
<0.01 \\
0.01 \\
0.04 \\
<0.01 \\
<0.01 \\
0.14 \\
<0.01 \\
<.01 \\
0.02 \\
0.01 \\
0.01 \\
0.03 \\
0.01\end{array}$ & $\begin{array}{r}0.16 \\
0.18 \\
1.1 \\
<0.10 \\
0.06 \\
0.17 \\
<0.10 \\
<0.20 \\
0.66 \\
<0.15 \\
0.10 \\
0.36 \\
0.16 \\
0.24 \\
0.26 \\
0.12\end{array}$ & $\begin{array}{r}16 \\
<12 \\
<7 \\
<12 \\
20 \\
30 \\
11 \\
12 \\
. \\
<10 \\
13 \\
17 \\
10 \\
<10 \\
20 \\
17\end{array}$ & $\begin{array}{r}130 \\
<212 \\
<97 \\
<120 \\
128 \\
128 \\
105 \\
243 \\
. \\
<147 \\
125 \\
308 \\
158 \\
<236 \\
170 \\
206\end{array}$ & $\begin{array}{c}3.2 \\
2.1 \\
5.5 \\
2.4 \\
5.1 \\
6.2 \\
3.5 \\
. \\
\vdots \\
2.3 \\
4.9 \\
2.1 \\
2.4 \\
3.3 \\
3.9\end{array}$ & $\begin{array}{r}26 \\
37 \\
76 \\
24 \\
33 \\
26 \\
34 \\
. \\
: \\
34 \\
47 \\
33 \\
57 \\
28 \\
47\end{array}$ \\
\hline \multirow{2}{*}{$\begin{array}{l}\text { Storm } \\
\text { beginning } \\
\text { date }\end{array}$} & \multirow{2}{*}{$\begin{array}{l}\text { Storm } \\
\text { ending } \\
\text { date }\end{array}$} & \multirow{2}{*}{$\begin{array}{l}\text { Rainfall } \\
\text { total } \\
\text { (in.) }\end{array}$} & \multicolumn{2}{|c|}{$\begin{array}{l}\text { Aluminum, } \\
\text { total } \\
\text { recoverable }\end{array}$} & \multicolumn{2}{|c|}{$\begin{array}{l}\text { Arsenic, } \\
\text { total }\end{array}$} & \multicolumn{2}{|c|}{$\begin{array}{l}\text { Chromium, } \\
\text { total } \\
\text { recoverable }\end{array}$} & \multicolumn{2}{|c|}{$\begin{array}{c}\text { Copper, } \\
\text { total } \\
\text { recoverable }\end{array}$} & \multicolumn{2}{|c|}{$\begin{array}{c}\text { Iron, } \\
\text { total } \\
\text { recoverable }\end{array}$} \\
\hline & & & $\mu \mathrm{g} / \mathrm{L}$ & $1 b$ & $\mu \mathrm{g} / \mathrm{L}$ & $1 b$ & $\mu \mathrm{g} /$ & $1 b$ & $\mu_{g} / L$ & $1 \mathrm{~b}$ & $\mu_{g} / L$ & $1 b$ \\
\hline $\begin{array}{l}12-29-81 \\
01-04-82 \\
02-14-82 \\
03-09-82 \\
03-10-82 \\
03-25-82 \\
03-28-82 \\
03-31-82 \\
09-24-82 \\
10-25-82 \\
10-26-82 \\
11-09-82 \\
01-18-83 \\
01-24-83 \\
02-28-83 \\
03-16-83 \\
03-23-83\end{array}$ & $\begin{array}{l}12-30-81 \\
01-04-82 \\
02-16-82 \\
03-10-82 \\
03-11-82 \\
03-26-82 \\
03-29-82 \\
03-31-82 \\
09-24-82 \\
10-25-82 \\
10-26-82 \\
11-09-82 \\
01-19-83 \\
01-24-83 \\
03-01-83 \\
03-16-83 \\
03-23-83\end{array}$ & $\begin{array}{l}0.38 \\
0.83 \\
0.65 \\
0.47 \\
0.30 \\
0.20 \\
0.45 \\
0.95 \\
0.22 \\
0.09 \\
0.69 \\
0.45 \\
0.85 \\
0.74 \\
1.1 \\
0.40 \\
0.57\end{array}$ & $\begin{array}{r}\dot{ } \\
\dot{ } \\
\dot{ } \\
\dot{ } \\
\dot{ } \\
\dot{ } \\
30 \\
80 \\
50 \\
\dot{ } \\
\dot{ }\end{array}$ & $\begin{array}{l}\dot{ } \\
\dot{:} \\
\dot{ } \\
\dot{ } \\
\dot{ } \\
\dot{0}\end{array}$ & $\begin{array}{l}\dot{ } \\
\dot{ } \\
\dot{ } \\
\dot{ } \\
\dot{ } \\
\dot{ } \\
\dot{ } \\
<1 \\
<1 \\
<1 \\
<1 \\
<1 \\
<1\end{array}$ & $\begin{array}{c}\dot{ } \\
\dot{ } \\
\dot{ } \\
\dot{ } \\
\dot{ } \\
\dot{0} \\
<0.02 \\
<0.01 \\
<0.02 \\
<0.02 \\
<0.02 \\
<0.01 \\
<0.01\end{array}$ & $\begin{array}{r}\dot{ } \\
\dot{ } \\
\dot{ } \\
\dot{ } \\
\dot{ } \\
\dot{ } \\
<1 \\
<1 \\
<i \\
\dot{ } \\
\end{array}$ & $\begin{array}{c}\dot{ } \\
\dot{0} \\
\dot{ } \\
\dot{ } \\
<0 \\
<0.01 \\
<0.02 \\
:\end{array}$ & $\begin{array}{l}\dot{5} \\
\dot{5} \\
\dot{5} \\
\dot{5} \\
\dot{ } \\
\dot{4} \\
6 \\
\dot{1} \\
\dot{.}\end{array}$ & $\begin{array}{c}\dot{ } \\
\dot{:} \\
\dot{ } \\
\dot{ } \\
\dot{0} \\
0.04 \\
0.11 \\
0.02 \\
:\end{array}$ & $\begin{array}{r}\dot{.} \\
\dot{.} \\
\dot{.} \\
\dot{5} \\
770 \\
1,400 \\
90 \\
360 \\
90 \\
40 \\
10 \\
170 \\
60\end{array}$ & $\begin{array}{c}\dot{ } \\
\dot{ } \\
\dot{ } \\
\dot{ } \\
3.6 \\
2.7 \\
1.3 \\
3.4 \\
1.6 \\
0.63 \\
0.24 \\
1.4 \\
0.73\end{array}$ \\
\hline
\end{tabular}


Table 11. Rainfall constituent event mean concentrations and loads for storms monitored at single-dwelling residential siteContinued

\begin{tabular}{|c|c|c|c|c|c|c|c|c|c|c|c|c|}
\hline \multirow{2}{*}{$\begin{array}{l}\text { Storm } \\
\text { beginning } \\
\text { date }\end{array}$} & \multirow{2}{*}{$\begin{array}{l}\text { Storm } \\
\text { ending } \\
\text { date }\end{array}$} & \multirow{2}{*}{$\begin{array}{l}\text { Rainfal1 } \\
\text { total } \\
\text { (in.) }\end{array}$} & \multicolumn{2}{|c|}{$\begin{array}{c}\text { Lead, } \\
\text { total } \\
\text { recoverable }\end{array}$} & \multicolumn{2}{|c|}{$\begin{array}{l}\text { Manganese, } \\
\text { total } \\
\text { recoverable }\end{array}$} & \multicolumn{2}{|c|}{$\begin{array}{c}\text { Mercury, } \\
\text { total } \\
\text { recoverable }\end{array}$} & \multicolumn{2}{|c|}{$\begin{array}{c}\text { Nickel, } \\
\text { total } \\
\text { recoverable }\end{array}$} & \multicolumn{2}{|c|}{$\begin{array}{c}\text { Zinc, } \\
\text { total } \\
\text { recoverable }\end{array}$} \\
\hline & & & $\mu_{g} / L$ & Ib & $\mu_{g} / L$ & $1 b$ & $\mu_{g} / L$ & $1 b$ & $\mu_{g} / L$ & $1 \mathrm{~b}$ & $\mu g / L$ & $1 b$ \\
\hline $\begin{array}{l}12-29-81 \\
01-04-82 \\
02-14-82 \\
03-09-82 \\
03-10-82 \\
03-25-82 \\
03-28-82 \\
03-31-82 \\
09-24-82 \\
10-25-82 \\
10-26-82 \\
11-09-82 \\
01-18-83 \\
01-24-83 \\
02-28-83 \\
03-16-83 \\
03-23-83\end{array}$ & $\begin{array}{l}12-30-81 \\
01-04-82 \\
02-16-82 \\
03-10-82 \\
03-11-82 \\
03-26-82 \\
03-29-82 \\
03-31-82 \\
09-24-82 \\
10-25-82 \\
10-26-82 \\
11-09-82 \\
01-19-83 \\
01-24-83 \\
03-01-83 \\
03-16-83 \\
03-23-83\end{array}$ & $\begin{array}{l}0.38 \\
0.83 \\
0.65 \\
0.47 \\
0.30 \\
0.20 \\
0.45 \\
0.95 \\
0.22 \\
0.09 \\
0.69 \\
0.45 \\
0.85 \\
0.74 \\
1.1 \\
0.40 \\
0.57\end{array}$ & $\begin{array}{r}3 \\
3 \\
15 \\
8 \\
10 \\
25 \\
9 \\
<4 \\
15 \\
61 \\
4 \\
5 \\
4 \\
4 \\
<1 \\
12 \\
8\end{array}$ & $\begin{array}{r}0.05 \\
0.21 \\
0.08 \\
0.06 \\
0.11 \\
0.09 \\
<0.08 \\
0.07 \\
0.12 \\
0.06 \\
0.05 \\
0.07 \\
0.06 \\
<0.02 \\
0.10 \\
0.10\end{array}$ & $\begin{array}{r}\dot{ } \\
\dot{ } \\
\dot{ } \\
\dot{ } \\
30 \\
60 \\
10 \\
10 \\
<10 \\
<10 \\
<10 \\
10 \\
<10\end{array}$ & $\begin{array}{c}\dot{ } \\
\dot{ } \\
\dot{ } \\
\dot{ } \\
0.14 \\
0.12 \\
0.15 \\
0.10 \\
<0.18 \\
<0.16 \\
<0.24 \\
0.08 \\
<0.12\end{array}$ & $\begin{array}{r}\dot{.} \\
\dot{.} \\
\dot{.} \\
\dot{.} \\
0.1 \\
0.1 \\
0.1 \\
<0.1 \\
0.1 \\
0.1 \\
<0.1\end{array}$ & $\begin{array}{c}\dot{ } \\
\dot{ } \\
\dot{ } \\
\dot{ } \\
\dot{ } \\
<0.01 \\
<0.01 \\
<0.01 \\
<0.01 \\
<0.01 \\
<0.01 \\
<0.01\end{array}$ & $\begin{array}{r}\dot{ } \\
\dot{ } \\
\dot{ } \\
\dot{ } \\
\dot{ } \\
5 \\
12 \\
9 \\
5 \\
<1 \\
10 \\
4 \\
10 \\
4\end{array}$ & $\begin{array}{c}\dot{ } \\
\dot{ } \\
\dot{ } \\
\dot{ } \\
0.02 \\
0.02 \\
0.13 \\
0.05 \\
<0.02 \\
0.16 \\
0.10 \\
0.08 \\
0.05\end{array}$ & $\begin{array}{r}\dot{ } \\
\dot{ } \\
\dot{ } \\
\dot{ } \\
\dot{ } \\
\dot{ } \\
60 \\
60 \\
30 \\
\dot{ } \\
.\end{array}$ & $\begin{array}{c}\dot{ } \\
\dot{ } \\
\dot{ } \\
\dot{ } \\
\dot{0} \\
\dot{0.58} \\
\dot{1.1} \\
0.71 \\
\dot{0}\end{array}$ \\
\hline
\end{tabular}


Table 12. Statistical summary of discrete runoff sample data: Industrial catchment

[Statistical calculations include analytical detection limit concentration for those analyses which are reported to be less than detection limit. Other organics were analyzed for but not detected and are given at the end of this table. <, actual value is less than value shown]

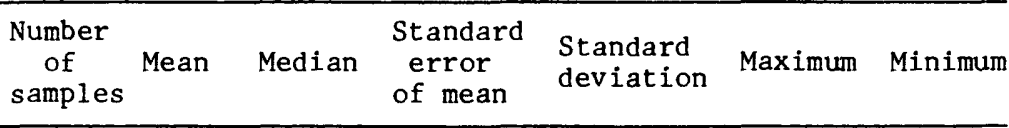

INORGANICS

Field measurements

Specific conductance ( $\mu \mathrm{S} / \mathrm{cm}$ at $\left.25^{\circ} \mathrm{C}\right) \ldots$

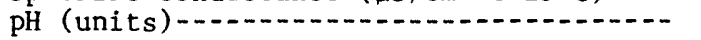

\section{5} 221

464

6.7

304

6.7

42
0.0

Major ions (mg/L)

Hardness, total (as $\left.\mathrm{CaCO}_{3}\right)$................

Calcium, dissolved-...

Magnesium, dissolved-

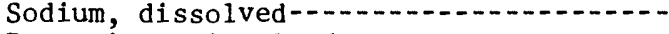

Potassium, dissolved-1...

Alkalinity, total (as $\mathrm{CaCO}_{3}$ ) ........

Sulfate, di ssolved-...

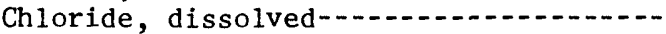

Silica, dissolved--

Nutrients (mg/L)

Nitrogen, nitrate, dissolved (as N)-...-

Nitrogen, nitrite plus nitrate,

dissolved (as N) -

Nitrogen, ammonia, dissolved (as N)-..-

Nitrogen, ammonia plus organic,

total (as N)

Nitrogen, ammonia plus organic,

dissolved (as N)

Nitrogen, organic, dissolved (as N)-..--

Nitrogen, dissolved (as N)

Phosphorus, total (as P)

Phosphorus, dissolved (as P)

Phosphorus, orthophosphate,

total (as P)

dissolved (as P)

Metals $(\mu \mathrm{g} / \mathrm{L})$

Aluminum, total recoverable

Aluminum, dissolved-......................

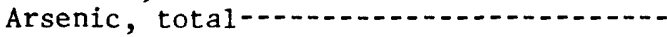

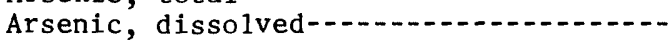

Cadmium, total recoverable-.................

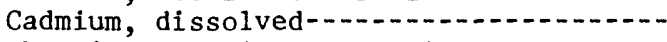

Chromium, total recoverable

Chromium, dissolved

Copper, total recoverable-............

Copper, dissolved-_...

Iron, total recoverable

Iron, dissolved-1

Lead, total recoverable

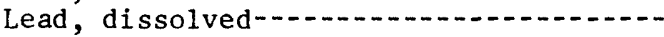

Manganese, total recoverable-.........

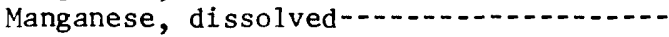

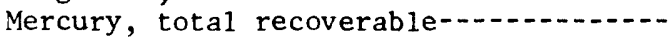

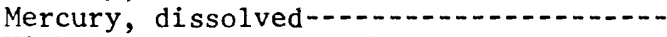

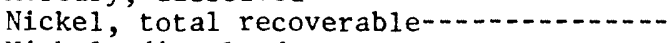

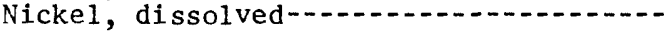

Zinc, total recoverable

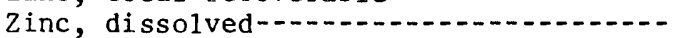

BIOLOGICAL

Coliform, fecal, $0.7 \mu \mathrm{m}-\mathrm{MF}$

(colonies/100 mL) -

$\begin{array}{rrrrrrr}101 & 65 & 48 & 5 & 52 & 410 & 17 \\ 101 & 15 & 11 & 1.4 & 14 & 120 & 4.0 \\ 101 & 6.4 & 4.9 & 0.5 & 4.6 & 26 & 1.6 \\ 102 & 74 & 19 & 19 & 200 & 1,800 & 5.7 \\ 99 & 24 & 22 & 1.1 & 11 & 62 & 5.2 \\ 101 & 84 & 79 & 5 & 47 & 221 & 5 \\ 102 & 25 & 16 & 2.0 & 21 & 110 & <5.0 \\ 102 & 110 & 24 & 32 & 320 & 3,000 & 4.8 \\ 74 & 5.4 & 4.0 & 0.6 & 5.0 & 30 & 1.6 \\ & & & & & & \\ 42 & 1.2 & 1.0 & 0.13 & 0.83 & 3.3 & 0.00 \\ 81 & 1.8 & 1.3 & 0.14 & 1.3 & 5.5 & 0.10 \\ 86 & 6.6 & 6.4 & 0.35 & 3.2 & 20 & 0.90 \\ 78 & 27 & 24 & 1.4 & 13 & 78 & 8.8 \\ & & & & & & \\ 83 & 18 & 17 & 0.93 & 8.5 & 45 & 3.6 \\ 86 & 12 & 10 & 0.79 & 7.3 & 38 & 0.1 \\ 79 & 20 & 18 & 1.2 & 10 & 54 & 4.0 \\ 90 & 6.6 & 6.3 & 0.29 & 2.8 & 20 & 0.92 \\ 89 & 5.0 & 4.7 & 0.25 & 2.4 & 11 & 0.40 \\ 71 & 4.5 & 4.0 & 0.25 & 2.1 & 10 & 0.72 \\ 66 & 3.7 & 3.3 & 0.23 & 1.8 & 9 & 0.68\end{array}$

16

16
107

107
68

70

69

86

69

86

85

107

102

107

106

37

37

107

69

107

106

86

81

10,000

$7,000 \quad 1,300$

1,300
21

5,300
82

18,000

3,000

160
17
10

14

9

1

0
0

2

17

2

89

16

12,000

620

95
10

520

180

0.2

0.2

27
9

740

250

20

9,700

4,250

2,300

10,000

31,000

$<120$

17

4.0
1.6

5.7

5

5.0

1.6

.00

0.10 8.8 3.6

4.0

0.92

.72

0.68

20

1

$<1$

$<1$

$<1$

$<1$

30
3
480

22

16

$<1$
170

46
$<0.1$

$<0.1$

4

$\begin{array}{rr}3,100 & 280 \\ 1,400 & 70\end{array}$

\section{6}


Table 12. Statistical summary of discrete runoff sample data: Industrial catchment-Continued

\begin{tabular}{|c|c|c|c|c|c|c|c|}
\hline Property or constituent & $\begin{array}{l}\text { Number } \\
\text { of } \\
\text { samples }\end{array}$ & Mean & Median & $\begin{array}{l}\text { Standard } \\
\text { error } \\
\text { of mean }\end{array}$ & $\begin{array}{l}\text { Standard } \\
\text { deviation }\end{array}$ & Maximum & Minimum \\
\hline \multicolumn{8}{|l|}{ OXYGEN DEMAND (mg/L) } \\
\hline \multicolumn{8}{|l|}{ Oxygen demand, chemical, } \\
\hline $0.25 \mathrm{~N}$ dichromate & 56 & 620 & 490 & 56 & 417 & 2,500 & 150 \\
\hline $\begin{array}{l}\text { Oxygen demand, biochemical, } \\
\text { carbonaceous, 5-day at } 20^{\circ}\end{array}$ & & 149 & 135 & 11 & & & \\
\hline oxygen demand, biochemical, & 42 & 149 & 135 & 11 & 10 & 330 & 30 \\
\hline carbonaceous, 20-day- & 42 & 189 & 160 & 20 & 126 & 830 & 39 \\
\hline \multicolumn{8}{|l|}{ PHYSICAL PROPERTIES } \\
\hline $\begin{array}{l}\text { Turbidity (NTU) } \\
\text { Solids, residue at } 180^{\circ} \mathrm{C} \text {, }\end{array}$ & 83 & 160 & 110 & 15 & 141 & 800 & 1 \\
\hline $\begin{array}{l}\text { dissolved (mg/L) } \\
\text { Solids, sum of constituents, }\end{array}$ & 93 & 423 & 242 & 67 & 648 & 5,870 & 77 \\
\hline dissolved $(\mathrm{mg} / \mathrm{L})$ & 96 & 321 & 165 & 56 & 545 & 4,997 & 63 \\
\hline Sediment, suspended (mg/L) & 100 & 684 & 500 & 62 & 619 & 2,770 & 51 \\
\hline \multicolumn{8}{|l|}{ ORGANICS } \\
\hline $\begin{array}{l}\text { Carbon, organic, dissolved } \\
(\mathrm{mg} / \mathrm{L} \text { as } \mathrm{C})\end{array}$ & 56 & 190 & 130 & 42 & 310 & 2,300 & 20 \\
\hline Carbon, organic, suspended & & & & & & & \\
\hline$(\mathrm{mg} / \mathrm{L}$ as $\mathrm{C})$ & 54 & 25 & 26 & 1.5 & 11 & 41 & 5.8 \\
\hline Cyanide, total (mg/L) & 3 & 0.01 & $<0.01$ & 0.00 & 0.00 & $<0.01$ & $<0.01$ \\
\hline $\begin{array}{l}\text { Cyanide, dissolved (mg/L) } \\
\text { Oil and grease, total recoverable, }\end{array}$ & 3 & 0.01 & $<0.01$ & 0.00 & 0.00 & $<0.01$ & $<0.01$ \\
\hline gravimetric $(\mathrm{mg} / \mathrm{L})$ & 15 & 11 & 4 & 5 & 20 & 80 & $<1$ \\
\hline Phenols, total recoverable $(\mu \mathrm{g} / \mathrm{L})$ & 5 & 114 & 20 & 96 & 216 & 500 & 8 \\
\hline \multicolumn{8}{|l|}{ Pesticides (total recoverable, $\mu g / L$ ) } \\
\hline Chlordane--n- & 19 & 0.12 & $<0.10$ & 0.01 & 0.05 & 0.30 & $<0.10$ \\
\hline DDE & 19 & 0.01 & 0.01 & 0.00 & 0.01 & 0.03 & $<0.01$ \\
\hline Diazinon- -1 & 18 & 0.67 & 0.53 & 0.17 & 0.71 & 3.3 & 0.14 \\
\hline Dieldrin- & 19 & 0.01 & $<0.01$ & 0.00 & 0.00 & 0.02 & $<0.01$ \\
\hline Endosulfan- & 19 & 0.01 & $<0.01$ & 0.00 & 0.00 & 0.02 & $<0.01$ \\
\hline Lindane-n. & 19 & 0.05 & 0.03 & 0.01 & 0.06 & 0.27 & 0.01 \\
\hline Malathion- & 18 & 0.66 & 0.44 & 0.16 & 0.67 & 3.0 & 0.20 \\
\hline Me thoxychlor & 19 & 0.01 & $<0.01$ & 0.00 & 0.00 & 0.03 & $<0.01$ \\
\hline Parathion- & 18 & 0.05 & $<0.01$ & 0.02 & 0.09 & 0.38 & $<0.01$ \\
\hline 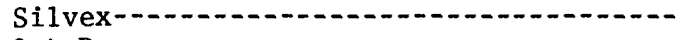 & 19 & 0.01 & $<0.01$ & 0.00 & 0.01 & 0.07 & $<0.01$ \\
\hline $2,4-D-\cdots-\cdots-\cdots+-\cdots$ & 19 & 0.26 & 0.03 & 0.17 & 0.72 & 3.2 & $<0.01$ \\
\hline
\end{tabular}

Other organics analyzed but not detected

\begin{tabular}{|c|c|c|c|c|c|}
\hline $\begin{array}{c}\text { Organic } \\
\text { (total recoverable) }\end{array}$ & $\begin{array}{c}\text { Detection } \\
\text { limit } \\
(\mu g / L)\end{array}$ & $\begin{array}{l}\text { Number } \\
\text { of } \\
\text { samples }\end{array}$ & $\begin{array}{c}\text { Organic } \\
\text { (total recoverable) }\end{array}$ & $\begin{array}{c}\text { Detection } \\
\text { limit } \\
(\mu g / L)\end{array}$ & $\begin{array}{l}\text { Number } \\
\text { of } \\
\text { samples }\end{array}$ \\
\hline Aldrin-ne & 0.01 & 19 & Heptachlor & 0.01 & 19 \\
\hline Benzene--nes & 1 & 5 & Heptachlor epoxide- & 0.01 & 19 \\
\hline Chlorobenzene- & & 5 & Methomy 1 - & 2 & 8 \\
\hline DDD-10- & 0.01 & 19 & Methyl parathion & 0.01 & 18 \\
\hline DDT-D-n & 0.01 & 19 & Methyl trithion & 0.01 & 19 \\
\hline Dibromochloropropane-n. & 0.003 & *7 & 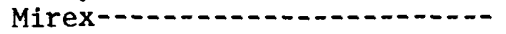 & 0.01 & 19 \\
\hline Endrin- & 0.01 & 19 & Perthane-1-n & 0.1 & 19 \\
\hline Ethion- & 0.01 & 19 & Propham-n- & 2 & 8 \\
\hline Ethylbenzene- & 1 & 5 & Sevin- & 2 & 8 \\
\hline Gross polychlorinated & & & Toxaphene- & 1 & 19 \\
\hline biphenyls -2 & 0.1 & 19 & Trithion- & 0.01 & 19 \\
\hline Gross polychlorinated & & & $2,4-D P-\cdots$ & 0.01 & 19 \\
\hline naphthalenes- & 0.1 & 19 & $2,4,5-\mathrm{T}-\cdots$ & 0.01 & 19 \\
\hline
\end{tabular}

*One sample had a concentration equal to the detection limit. 
Table 13. Statistical summary of discrete runoff sample data: Single-dwelling residential catchment

[Statistical calculations include analytical detection limit concentration for those analyses which are reported to be less than detection limit. Other organics were analyzed for but not detected and are given at the end of this table. <, actual value is less than value shown]

\begin{tabular}{|c|c|c|c|c|c|c|c|}
\hline Property or constituent & $\begin{array}{l}\text { Number } \\
\text { of } \\
\text { samples }\end{array}$ & Mean & Median & $\begin{array}{l}\text { Standard } \\
\text { error } \\
\text { of mean }\end{array}$ & $\begin{array}{l}\text { Standard } \\
\text { deviation }\end{array}$ & Maximum & Minimum \\
\hline
\end{tabular}

\section{INORGANICS}

Field measurements

Specific conductance $\left(\mu \mathrm{S} / \mathrm{cm}\right.$ at $\left.25^{\circ} \mathrm{C}\right)-\cdots \quad 121$

$\mathrm{pH}$ (units)

97

Major ions (mg/L)

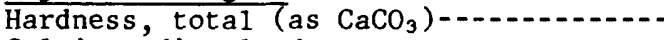

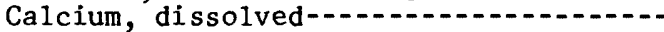

Magnesium, dissolved--.-..-.

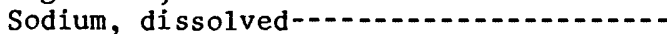

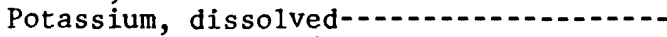

Alkalinity, total (as $\left.\mathrm{CaCO}_{3}\right)$

Sulfate, dissolved-...

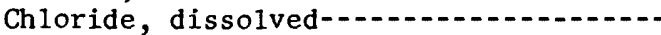

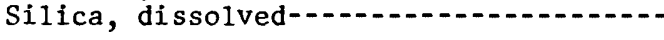

Nutrients (mg/L)

Nitrogen, nitrate, dissolved (as N) -...-

Nitrogen, nitrite plus nitrate,

dissolved (as N) -

Nitrogen, ammonia, dissolved (as N) -...

Nitrogen, ammonia plus organic, total (as N)

Nitrogen, ammonia plus organic, dissolved (as $\mathrm{N}$ ) dissolved (as $\mathrm{N})-1$.

Nitrogen, organic, dissolved (as N) - -

Nitrogen, dissolved (as N)
Phosphorus, total (as P)

Phosphorus, dissolved (as P) -............

Phosphorus, orthophosphate,

total (as P)

Phosphorus, orthophosphate,

dissolved (as P)

Metals ( $\mu \mathrm{g} / \mathrm{L})$

Aluminum, total recoverable-.........

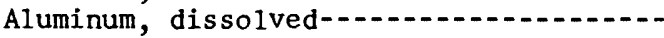

Arsenic, total-...

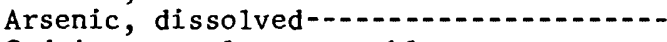

Cadmium, total recoverable-..........

Cadmium, dissolved-......................

Chromium, total recoverable-..........

Chromium, dissolved-...................

Copper, total recoverable-....

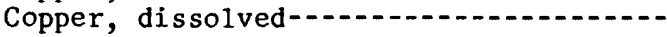

Iron, total recoverable

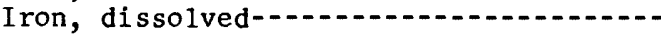

Lead, total recoverable-.....

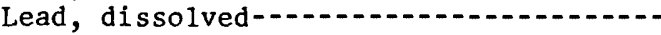

Manganese, total recoverable-.........

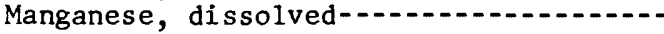

Mercury, total recoverable-..............

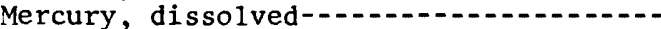

Nickel, total recoverable-............

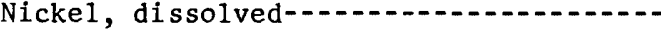

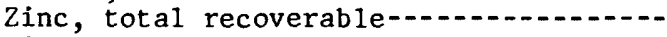

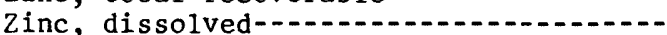

\section{BIOLOGICAL}

Coliform, fecal, $0.7 \mu \mathrm{m}-\mathrm{MF}$

(colonies $/ 100 \mathrm{~mL}$ ) -.....

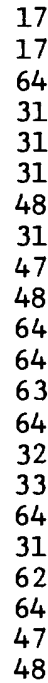

$\begin{array}{rrrrrrr}62 & 20 & 15 & 2 & 16 & 70 & 4 \\ 65 & 5.8 & 4.7 & 0.5 & 4.1 & 18 & 1.3 \\ 65 & 1.3 & 0.7 & 0.2 & 1.4 & 6.2 & 0.1 \\ 65 & 3.9 & 3.2 & 0.4 & 3.0 & 18 & 0.7 \\ 65 & 3 & 2.3 & 0.3 & 2.4 & 9.8 & 0.8 \\ 65 & 19 & 15 & 2 & 14 & 73 & 7 \\ 61 & 8 & 7 & 1 & 4 & 27 & 4 \\ 64 & 3.3 & 2.5 & 0.4 & 3.1 & 14 & 0.6 \\ 44 & 3.0 & 2.2 & 0.6 & 4.0 & 27 & 0.8 \\ & & & & & & \\ 25 & 0.75 & 0.49 & 0.12 & 0.58 & 2.1 & 0.18 \\ 65 & 0.93 & 0.50 & 0.13 & 1.0 & 4.7 & 0.11 \\ 65 & 1.4 & 0.69 & 0.18 & 1.5 & 6.4 & 0.12 \\ & & & & & & \\ 55 & 4.5 & 2.7 & 0.61 & 4.5 & 22 & 0.57 \\ 64 & 3.8 & 2.1 & 0.5 & 3.8 & 16 & 0.5 \\ 62 & 2.6 & 1.5 & 0.3 & 2.7 & 12 & 0.2 \\ 64 & 4.8 & 2.4 & 0.60 & 4.8 & 21 & 0.63 \\ 65 & 0.63 & 0.39 & 0.07 & 0.59 & 2.4 & 0.10 \\ 65 & 0.37 & 0.23 & 0.04 & 0.32 & 1.6 & 0.09 \\ 64 & 0.37 & 0.22 & 0.05 & 0.38 & 2.2 & 0.10 \\ 64 & 0.31 & 0.20 & 0.04 & 0.29 & 1.6 & 0.09\end{array}$

$\begin{array}{rrr}5,000 & 3,400 & 1,300 \\ 100 & 50 & 30 \\ 2 & 1 & 0 \\ 1 & 1 & 0 \\ 1 & 1 & 0 \\ 2 & 2 & 0 \\ 9 & 8 & 1 \\ 1 & <1 & 0 \\ 32 & 14 & 6 \\ 6 & 5 & 1 \\ 4,600 & 1,700 & 790 \\ 190 & 91 & 28 \\ 350 & 170 & 53 \\ 42 & 25 & 5 \\ 160 & 110 & 30 \\ 50 & 23 & 10 \\ 0.6 & 0.1 & 0.2 \\ 0.1 & <0.1 & 0.0 \\ 19 & 11 & 3 \\ 6 & 4 & 1 \\ 210 & 90 & 40 \\ 70 & 43 & 10\end{array}$

5,400
110
2
1
1
1
7
1
40
4
6,300
230
420
41
150
60
1.4
0.0
22
7
280
71

$\begin{array}{rr}20,000 & 530 \\ 370 & 30 \\ 8 & <1 \\ 5 & <1 \\ 4 & <1 \\ 4 & <1 \\ 40 & <1 \\ 4 & <1 \\ 180 & 4 \\ 21 & <1 \\ 29,000 & 160 \\ 960 & 29 \\ 2,100 & 15 \\ 200 & 2 \\ 480 & 20 \\ 210 & 5 \\ 8.6 & <0.1 \\ 0.1 & <0.1 \\ 85 & 1 \\ 30 & <1 \\ 1,300 & 30 \\ 350 & 21\end{array}$


Table 13. Statistical summary of discrete runoff sample data: Single-dwelling residential catchment-Continued

\begin{tabular}{|c|c|c|c|c|c|c|c|}
\hline Property or constituent & $\begin{array}{l}\text { Number } \\
\text { of } \\
\text { samples }\end{array}$ & Mean & Median & $\begin{array}{l}\text { Standard } \\
\text { error } \\
\text { of mean }\end{array}$ & $\begin{array}{l}\text { Standard } \\
\text { deviation }\end{array}$ & Maximum & Minimum \\
\hline \multicolumn{8}{|l|}{ OXYGEN DEMAND $(\mathrm{mg} / \mathrm{L})$} \\
\hline Oxygen demand, chemical, & & & & & & & \\
\hline $0.25 \mathrm{~N}$ dichromate & 34 & 106 & 95 & 10 & 56 & 290 & 27 \\
\hline Oxygen demand, biochemical, & & & & & & & \\
\hline $\begin{array}{l}\text { carbonaceous, 5-day at } 20^{\circ} \mathrm{C} \\
\text { oxygen demand, biochemical, }\end{array}$ & 22 & 14.6 & 8.3 & 3.4 & 16 & 53 & 2.1 \\
\hline carbonaceous, 20-day- & 22 & 21 & 12 & 4.7 & 22 & 81 & 2.3 \\
\hline \multicolumn{8}{|l|}{ PHYSICAL PROPERTIES } \\
\hline $\begin{array}{l}\text { Turbidity (NTU) } \\
\text { Solids, residue at } 180^{\circ} \mathrm{C} \text {, }\end{array}$ & 49 & 57 & 11 & 20 & 138 & 900 & 1.7 \\
\hline $\begin{array}{l}\text { dissolved (mg/L) } \\
\text { Solids, sum of constituents, }\end{array}$ & 64 & 63 & 46 & 6 & 48 & 224 & 9 \\
\hline dissolved (mg/L) & 64 & 45 & 34 & 4 & 31 & 155 & 13 \\
\hline Sediment, suspended (mg/L) & 64 & 246 & 70 & 48 & 380 & 1,540 & 9 \\
\hline \multicolumn{8}{|l|}{ ORGANICS } \\
\hline $\begin{array}{l}\text { Carbon, organic, dissolved } \\
\text { (mg/L as C) } \\
\text { Carbon, organic, suspended }\end{array}$ & 36 & 75 & 46 & 16 & 96 & 550 & 4 \\
\hline$(\mathrm{mg} / \mathrm{L}$ as $\mathrm{C})$ & 33 & 3.2 & 2.3 & 0.6 & 3.2 & 17 & 0.8 \\
\hline Cyanide, total (mg/L) & 5 & 0.01 & $<0.01$ & 0.00 & 0.00 & $<0.01$ & $<0.01$ \\
\hline $\begin{array}{l}\text { Cyanide, dissolved (mg/L) } \\
\text { Oil and grease, total recoverable, }\end{array}$ & 5 & 0.01 & $<0.01$ & 0.00 & 0.00 & $<0.01$ & $<0.01$ \\
\hline gravimetric (mg/L) & 11 & 3 & 2 & 1 & 2 & 8 & 1 \\
\hline Phenols, total recoverable $(\mu \mathrm{g} / \mathrm{L})$ & 5 & 22 & 18 & 4 & 10 & 35 & 13 \\
\hline \multicolumn{8}{|l|}{ Pesticides (total recoverable, $\mu \mathrm{g} / \mathrm{L}$ ) } \\
\hline Chlordane--n- & 16 & 0.16 & 0.10 & 0.02 & 0.07 & 0.30 & 0.10 \\
\hline 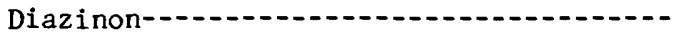 & 16 & 0.36 & 0.27 & 0.07 & 0.27 & 1.1 & 0.11 \\
\hline 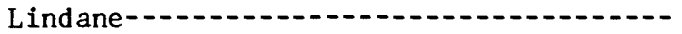 & 16 & 0.03 & 0.03 & 0.00 & 0.02 & 0.06 & 0.01 \\
\hline Malathion-- & 16 & 2.2 & 0.99 & 0.82 & 3.3 & 13 & 0.19 \\
\hline Methoxychlor & 16 & 0.03 & $<0.01$ & 0.01 & 0.05 & 0.19 & $<0.01$ \\
\hline Methyl parathion- & 16 & 0.01 & $<0.01$ & 0.00 & 0.00 & 0.03 & $<0.01$ \\
\hline Parathion- & 16 & 0.21 & 0.13 & 0.07 & 0.26 & 0.92 & $<0.01$ \\
\hline Silvex-10 & 16 & 0.01 & $<0.01$ & 0.00 & 0.00 & 0.03 & $<0.01$ \\
\hline $2,4-D-10$ & 16 & 0.26 & 0.07 & 0.13 & 0.51 & 1.7 & $<0.01$ \\
\hline
\end{tabular}

Other organics analyzed but not detected

\begin{tabular}{|c|c|c|c|c|c|}
\hline $\begin{array}{c}\text { Organic } \\
\text { (total recoverable) }\end{array}$ & $\begin{array}{c}\text { Detection } \\
\text { limit } \\
(\mu g / L)\end{array}$ & $\begin{array}{l}\text { Number } \\
\text { of } \\
\text { samples }\end{array}$ & $\begin{array}{c}\text { Organic } \\
\text { (total recoverable) }\end{array}$ & $\begin{array}{c}\text { Detection } \\
\text { limit } \\
(\mu g / L)\end{array}$ & $\begin{array}{l}\text { Number } \\
\text { of } \\
\text { samples }\end{array}$ \\
\hline Aldrin-- & 0.01 & 16 & Heptach lor & 0.01 & 16 \\
\hline Benzene-- & 1 & 3 & Heptachlor epoxide-- & 0.01 & 16 \\
\hline Chlorobenzene- & 1 & 3 & Methomy 1 - & 2 & 4 \\
\hline DDD-1 & 0.01 & 16 & Methyl trithion- & 0.01 & 16 \\
\hline DDE--20 & 0.01 & *16 & Mirex-1- & 0.01 & 16 \\
\hline DDT & 0.01 & $\star * 16$ & Perthane-1- & 0.01 & 16 \\
\hline Dibromoch loropropane---- & 0.003 & $\star * 4$ & Propham-1-0 & 0.01 & 4 \\
\hline Dieldrin-1 & 0.01 & *16 & 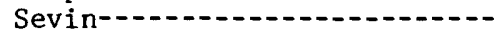 & 2 & 4 \\
\hline Endosulfan- & 0.01 & $\star \star 16$ & Silvex-1 & 0.01 & 16 \\
\hline Endrin- & 0.01 & $* * 16$ & Toxaphene-1- & 0.1 & 16 \\
\hline Ethion- & 0.01 & 16 & Trithion- & 2 & 16 \\
\hline Ethylbenzene- & 1 & 3 & $2,4-\mathrm{DP}=$ & 2 & 16 \\
\hline \multicolumn{6}{|l|}{ Gross polychlorinated } \\
\hline biphenyls & 0.1 & 16 & & & \\
\hline \multicolumn{6}{|l|}{ Gross polychlorinated } \\
\hline naphthalenes & 0.1 & 16 & & & \\
\hline
\end{tabular}

* Four samples had concentrations equal to the detection limit. **One sample had a concentration equal to the detection limit. 
Table 14. Statistical summary of discrete runoff sample data: Multiple-dwelling residential catchment

[Statistical calculations include analytical detection limit concentration for those analyses which are reported to be less than detection limit. Other organics were analyzed for but not detected and are given at the end of this table. <, actual value is less than value shown]

\begin{tabular}{|c|c|c|c|c|c|c|c|}
\hline Property or constituent & $\begin{array}{l}\text { Number } \\
\text { of } \\
\text { samples }\end{array}$ & Mean & Median & $\begin{array}{l}\text { Standard } \\
\text { error } \\
\text { of mean }\end{array}$ & $\begin{array}{l}\text { Standard } \\
\text { deviation }\end{array}$ & Maximum & Minimum \\
\hline \multicolumn{8}{|l|}{ INORGANICS } \\
\hline Specific conductance $\left(\mu \mathrm{S} / \mathrm{cm}\right.$ at $\left.25^{\circ} \mathrm{C}\right)$ & \multicolumn{6}{|c|}{ Field measurements } & \\
\hline $\mathrm{pH}$ (units) & 169 & 7.1 & 7.0 & 0.0 & 0.3 & 8.8 & 6.4 \\
\hline \multicolumn{8}{|l|}{ Major ions (mg/L) } \\
\hline $\begin{array}{l}\text { Hardness, total (as } \mathrm{CaCO}_{3} \text { ) } \\
\text { Calcium, dissolved }\end{array}$ & $\begin{array}{l}85 \\
87\end{array}$ & $\begin{array}{r}30 \\
8.3\end{array}$ & $\begin{array}{r}14 \\
4.3\end{array}$ & $\begin{array}{r}4 \\
1.1\end{array}$ & $\begin{array}{l}37 \\
10\end{array}$ & $\begin{array}{r}230 \\
65\end{array}$ & $\begin{array}{r}6 \\
2.0\end{array}$ \\
\hline Magnesium, dissolved & 87 & 2.1 & 0.9 & 0.3 & 2.8 & 16 & 0.3 \\
\hline Sodium, díssolved- & 87 & 6.8 & 3.8 & 0.9 & 8.5 & 49 & 1.0 \\
\hline Potassium, dissolved & 87 & 3.4 & 2.2 & 0.3 & 3.2 & 19 & 0.8 \\
\hline Alkalinity, total (as $\left.\mathrm{CaCO}_{3}\right)$ & 89 & 25 & 15 & 2 & 24 & 150 & 6 \\
\hline Sulfate, dissolved & 88 & 12 & 8.0 & 1.3 & 12 & 76 & 3.6 \\
\hline Chloride, dissolved & 88 & 5.1 & 2.0 & 0.9 & 8.8 & 65 & 0.6 \\
\hline Silica, dissolved & & 4.7 & 2.8 & 0.6 & 5.4 & 25 & 1.5 \\
\hline \multicolumn{8}{|l|}{ Nutrients (mg/L) } \\
\hline Nitrogen, nitrate, dissolved (as N) & 45 & 0.89 & 0.53 & 0.19 & 1.2 & 6.6 & 0.14 \\
\hline Nitrogen, nitrite plus nitrate, & & & & & & & \\
\hline dissolved (as N) & 88 & 1.1 & 0.60 & 0.16 & 1.5 & 7.5 & $<0.10$ \\
\hline $\begin{array}{l}\text { Nitrogen, ammonia, dissolved (as N) } \\
\text { Nitrogen, ammonia plus organic, }\end{array}$ & 88 & 1.4 & 0.94 & 0.15 & 1.4 & 7.3 & $<0.06$ \\
\hline total (as N) & 85 & 5.2 & 2.7 & 0.64 & 5.9 & 25 & 0.83 \\
\hline Nitrogen, ammonia plus organic, & & & & . & 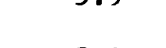 & & \\
\hline dissolved (as $\mathrm{N}$ ) & 88 & 4.3 & 2.5 & 0.5 & 5.0 & 26 & $<0.2$ \\
\hline Nitrogen, organic, dissolved (as N) & 84 & 2.9 & 1.3 & 0.5 & 4.2 & 25 & 0.2 \\
\hline Nitrogen, dissolved (as N) & 86 & 5.5 & 3.4 & 0.71 & 6.6 & 33 & 0.82 \\
\hline Phosphorus, total (as P) & 89 & 0.81 & 0.43 & 0.10 & 0.97 & 5.0 & 0.08 \\
\hline Phosphorus, dissolved (as P) & 87 & 0.58 & 0.30 & 0.08 & 0.77 & 4.7 & 0.06 \\
\hline Phosphorus, orthophosphate, & & & & & & & \\
\hline total (as P) & 87 & 0.46 & 0.27 & 0.05 & 0.46 & 2.4 & 0.07 \\
\hline $\begin{array}{l}\text { Phosphorus, orthophosphate, } \\
\text { dissolved (as P) }\end{array}$ & 88 & 0.38 & 0.22 & 0.04 & 0.39 & 2.1 & 0.03 \\
\hline \multicolumn{8}{|l|}{ Metals $(\mu \mathrm{g} / \mathrm{L})$} \\
\hline Aluminum, total recoverable & 17 & $1.2,000$ & 6,300 & 2,800 & 11,000 & 37,000 & 1,600 \\
\hline Aluminum, dissolved & 14 & 250 & 195 & 50 & 170 & 570 & 50 \\
\hline Arsenic, total & 87 & 3 & 2 & 0 & 3 & 16 & $<1$ \\
\hline Arsenic, dissolved & 51 & 2 & 1 & 0 & 2 & 10 & $<1$ \\
\hline Cadmium, total recoverable- & 53 & 2 & 1 & 0 & 1 & 6 & $<1$ \\
\hline Cadmium, dissolved- & 51 & 2 & $<1$ & 0 & 1 & 5 & $<1$ \\
\hline Chromium, total recoverable & 70 & 16 & 15 & 1 & 10 & 62 & 1 \\
\hline Chromium, dissolvedno & 51 & 1 & $<1$ & 0 & 1 & 4 & $<1$ \\
\hline Copper, total recoverable & 70 & 39 & 22 & 6 & 49 & 270 & 7 \\
\hline Copper, dissolved- & 66 & 9 & 5 & 1 & 11 & 58 & 1 \\
\hline Iron, total recoverable & 91 & 11,000 & 5,600 & 1,400 & 14,000 & 72,000 & 450 \\
\hline 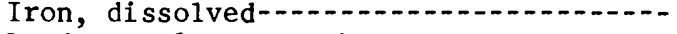 & 87 & 250 & 150 & 30 & 280 & 1,800 & 20 \\
\hline Lead, total recoverable & 91 & 225 & 170 & 20 & 190 & 940 & 25 \\
\hline Lead, dissolved & 87 & 20 & 12 & 2 & 19 & 86 & 1 \\
\hline 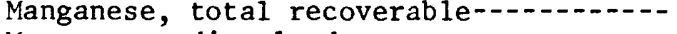 & 38 & 400 & 200 & 70 & 430 & 1,600 & 40 \\
\hline Manganese, dissolved-..... & 36 & 110 & 56 & 22 & 130 & 470 & 9 \\
\hline Mercury, total recoverablen................. & 88 & 0.3 & 0.2 & 0.0 & 0.3 & 1.6 & $<0.1$ \\
\hline Mercury, dissolved & 51 & 0.2 & $<0.1$ & 0.0 & 0.3 & 2.3 & 0.0 \\
\hline 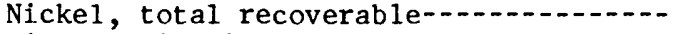 & 91 & 40 & 19 & 6 & 54 & 310 & 2 \\
\hline 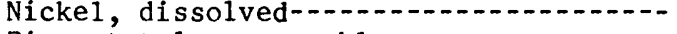 & 87 & 10 & 5 & 2 & 15 & 78 & $<1$ \\
\hline Zinc, total recoverable & 70 & 290 & 170 & 40 & 320 & 1,800 & 60 \\
\hline Zinc, dissolved & 66 & 110 & 50 & 19 & 151 & 840 & 20 \\
\hline $\begin{array}{l}\text { 3IOLOGICAL } \\
\text { Coliform, fecal, } 0 .\end{array}$ & & & & & & & \\
\hline (colonies $/ 100 \mathrm{~mL})-$ & 37 & 6,000 & 2,500 & 1,800 & 11,000 & 62,000 & 400 \\
\hline
\end{tabular}


Table 14. Statistical summary of discrete runoff sample data: Multiple-dwelling residential catchment-Continued

\begin{tabular}{|c|c|c|c|c|c|c|c|}
\hline Property or constituent & $\begin{array}{l}\text { Number } \\
\text { of } \\
\text { samples }\end{array}$ & Mean & Median & $\begin{array}{l}\text { Standard } \\
\text { error } \\
\text { of mean }\end{array}$ & $\begin{array}{l}\text { Standard } \\
\text { deviation }\end{array}$ & Maximum & Minimum \\
\hline \multicolumn{8}{|l|}{ OXYGEN DEMAND (mg/L) } \\
\hline $0.25 \mathrm{~N}$ dichromate & 58 & 160 & 89 & 31 & 240 & 1,400 & 31 \\
\hline $\begin{array}{l}\text { Oxygen demand, biochemical, } \\
\text { carbonaceous, } 5 \text {-day at } 20^{\circ} \mathrm{C}-\cdots \\
\text { Oxygen demand, biochemical, }\end{array}$ & 45 & 15 & 7.2 & 3.0 & 20 & 110 & 3.1 \\
\hline carbonaceous, 20-day---- & 45 & 23 & 12 & 4.4 & 30 & 150 & 5.2 \\
\hline \multicolumn{8}{|l|}{ PHYSICAL PROPERTIES } \\
\hline $\begin{array}{l}\text { Turbidity (NTU) } \\
\text { Solids, residue at } 180^{\circ} \mathrm{C} \text {, }\end{array}$ & 72 & 49 & 28 & 7.2 & 62 & 320 & 2.0 \\
\hline $\begin{array}{l}\text { dissolved (mg/L) } \\
\text { Solids, sum of constituents, }\end{array}$ & 81 & 104 & 46 & 16 & 140 & 775 & 14 \\
\hline dissolved (mg/L) & 182 & 49 & 32 & 4 & 50 & 407 & 16 \\
\hline Sediment, suspended (mg/L) & 86 & 638 & 333 & 87 & 804 & 4,300 & 8 \\
\hline \multicolumn{8}{|l|}{ ORGANICS } \\
\hline $\begin{array}{l}\text { (mg/L as } \mathrm{C}) \\
\text { Carbon, organic, suspended }\end{array}$ & 58 & 64 & 23 & 12 & 92 & 460 & 5 \\
\hline$(\mathrm{mg} / \mathrm{L}$ as $\mathrm{C})$ & 54 & 3.7 & 2.9 & 0.4 & 2.8 & 15 & 1.3 \\
\hline Cyanide, total (mg/L) & 5 & 0.01 & $<0.01$ & 0.00 & 0.00 & $<0.01$ & $<0.01$ \\
\hline $\begin{array}{l}\text { Cyanide, dissolved (mg/L) } \\
\text { Oil and grease, total recoverable, }\end{array}$ & 5 & 0.01 & $<0.01$ & 0.00 & 0.00 & $<0.01$ & $<0.01$ \\
\hline gravimetric (mg/L) - & 17 & 2 & 1 & 0 & 1 & 5 & $<1$ \\
\hline Phenols, total recoverable $(\mu \mathrm{g} / \mathrm{L})-$ & 9 & 20 & 16 & 4 & 11 & 41 & \\
\hline \multicolumn{8}{|l|}{ Pesticides (total recoverable, $\mu \mathrm{g} / \mathrm{L}$ ) } \\
\hline Aldrin-:- & 27 & 0.01 & $<0.01$ & 0.00 & 0.00 & 0.02 & $<0.01$ \\
\hline Chlordane & 26 & 0.25 & 0.10 & 0.05 & 0.27 & 1.2 & $<0.10$ \\
\hline DDE & 27 & 0.01 & $<0.01$ & 0.00 & 0.01 & 0.06 & $<0.01$ \\
\hline Diazinon- & 27 & 0.70 & 0.22 & 0.30 & 1.6 & 8.1 & 0.06 \\
\hline Dibromoch loropropane----... & 7 & 0.003 & $<0.003$ & 0.00 & 0.00 & 0.004 & $<0.003$ \\
\hline Dieldrin- & 27 & 0.01 & $<0.01$ & 0.00 & 0.00 & 0.02 & $<0.01$ \\
\hline Lindane- & 27 & 0.01 & 0.01 & 0.00 & 0.01 & 0.03 & $<0.01$ \\
\hline 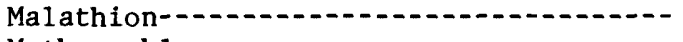 & 27 & 1.3 & 0.49 & 0.51 & 2.7 & 14 & 0.08 \\
\hline Methoxych1or- & 27 & 0.01 & $<0.01$ & 0.00 & 0.00 & 0.02 & $<0.01$ \\
\hline Parathion-- & 27 & 0.20 & 0.06 & 0.09 & 0.48 & 2.5 & $<0.01$ \\
\hline $2,4-D-\cdots$ & 26 & 0.36 & 0.08 & 0.16 & 0.80 & 3.7 & $<0.01$ \\
\hline
\end{tabular}

Other organics analyzed but not detected

\begin{tabular}{|c|c|c|c|c|c|}
\hline $\begin{array}{c}\text { Organic } \\
\text { (tota1 recoverable) }\end{array}$ & $\begin{array}{l}\text { Detection } \\
\text { limit } \\
\quad(\mu \mathrm{g} / \mathrm{L})\end{array}$ & $\begin{array}{l}\text { Number } \\
\text { of } \\
\text { samples }\end{array}$ & $\begin{array}{c}\text { Organic } \\
\text { (total recoverable) }\end{array}$ & $\begin{array}{l}\text { Detection } \\
\quad 1 \text { imit } \\
\quad(\mu g / L)\end{array}$ & $\begin{array}{l}\text { Number } \\
\text { of } \\
\text { samples }\end{array}$ \\
\hline Benzene--.--..... & 1 & 7 & Heptach 1or epoxide-- & 0.01 & 27 \\
\hline Chlorobenzene-.......... & 1 & 7 & Methomy $1 \ldots$ & 2 & 8 \\
\hline DDD- & 0.01 & 27 & Methyl parathion-...... & 0.01 & 27 \\
\hline DDT-10.-1 & 0.01 & $* 27$ & Methyl trithion- & 0.01 & 27 \\
\hline Endosulfan- & 0.01 & 27 & Mirex-10 & 0.01 & 27 \\
\hline Endrin- & 0.01 & 27 & Perthane- & 0.1 & 27 \\
\hline Ethion- & 0.01 & 27 & Propham- & $\frac{11}{2}$ & 8 \\
\hline Ethylbenzene-1. & 1 & 7 & Sevin- & 2 & 8 \\
\hline Gross polychlorinated & & & Silvex-1. & 0.01 & 26 \\
\hline biphenyls - - & 0.1 & $\star \star 27$ & Toxaphene--.--....- & 1 & 27 \\
\hline Gross polychlorinated & & & Trithion- & 0.01 & 27 \\
\hline naphthalenes- & 0.1 & 27 & $2,4-D P \cdots$ & 0.01 & 26 \\
\hline Heptachlor- & 0.01 & 27 & $2,4,5-\mathrm{T}-\cdots$ & 0.01 & 26 \\
\hline
\end{tabular}

*Three samples had concentrations equal to the detection limit.

**One sample had a concentration equal to the detection limit. 
Table 15. Statistical summary of discrete runoff sample data: Commercial catchment

[Statistical calculations include analytical detection limit concentration for those analyses which are reported to be less than detection limit. Other organics were analyzed for but not detected and are given at the end of this table. <, actual value is less than value shown]

\begin{tabular}{|c|c|c|c|c|c|c|c|}
\hline Property or constituent & $\begin{array}{l}\text { Number } \\
\text { of } \\
\text { samples }\end{array}$ & Mean & Median & $\begin{array}{l}\text { Standard } \\
\text { error } \\
\text { of mean }\end{array}$ & $\begin{array}{l}\text { Standard } \\
\text { deviation }\end{array}$ & Maximum & Minimum \\
\hline
\end{tabular}

\section{INORGANICS \\ Field measurements}

Specific conductance ( $\mu \mathrm{S} / \mathrm{cm}$ at $\left.25^{\circ} \mathrm{C}\right)-\cdots$ $\mathrm{pH}$ (units)

256

203

Major ions (mg/L)

Hardness, total (as $\left.\mathrm{CaCO}_{3}\right)$

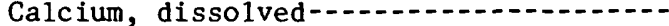

Magnesium, dissolved-_....................

Sodium, dissolved-........................

Potassium, dissolved-........................

Alkalinity, total (as $\mathrm{CaCO}_{3}$ )

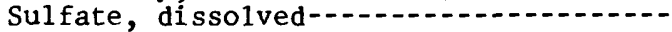

Chloride, dissolved-.....

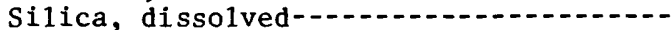

Nutrients (mg/L)

Nitrogen, nitrate, dissolved (as N)-..--

Nitrogen, nitrite plus nitrate,

dissolved (as $\mathrm{N}$ ) -......

Nitrogen, ammonia, dissolved (as N) -...-

Nitrogen, ammonia plus organic,

total (as N) -.........................

Nitrogen, ammonia p1us organic,

dissolved (as $\mathrm{N}$ ) -

Nitrogen, organic, dissolved (as N)-.-.-

Nitrogen, dissolved (as N) -.....

Phosphorus, total (as P)

Phosphorus, dissolved (as P)

Phosphorus, orthophosphate,

total (as P)

Phosphorus, or thophosphate,

dissolved (as P)

Metals ( $\mu \mathrm{g} / \mathrm{L})$

Aluminum, total recoverable-........

Aluminum, dissolved-....................

Arsenic, tota1-...

Arsenic, dissolved-...................

Cadmium, total recoverable-..........

Cadmium, dissolved-.....................

Chromium, total recoverable-......

Chromium, dissolved-...................

Copper, total recoverable-1..-

Copper, dissolved-....

Iron, total recoverable-.......

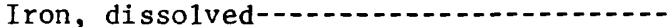

Lead, total recoverable-..................

Lead, dissolved-1.....

Manganese, total recoverable-.......-

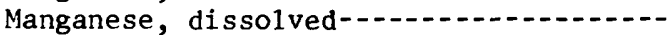

Mercury, total recoverable-.............

Mercury, dissolved-_...

Nickel, total recoverable-...........

Nickel, dissolved-........................

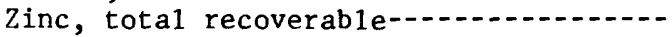

Zinc, dissolved-....

BIOLOGICAL

Coliform, fecal, $0.7 \mu \mathrm{m}-\mathrm{MF}$

(colonies/100 mL) -

95
96
96
96
96
96
95
95
64

39

87

87

82

$\begin{array}{rr}90 & 28 \\ 6.9 & 6.9\end{array}$

9

146

0.4

868

8.9

6.1

49

11

8
2.1

73

20

5.6

3.5

3.4
0.7

0.6

$6.8 \quad 2.7$

0.9

2.9

1.1

0.4

5
3.3

21

5.4

10
7

3.3
0.8

3.2

1.8
1.5

0.8

9.0

3.7
52

52
32

7.4

6.4

330

22

37

15

257

190

31

44

3
0.8

0.1

0.6

0.3

1
3.1
0.2

0.5

0.78

0.41

0.15

0.93

4.5

0.14

2.1

0.55

0.44

4.1

22

$<0.10$

$\begin{array}{lll}2.2 & 1.0 & 0.33\end{array}$

3.1

0.22

6.3

2.3

1.0

9.2

61

0.57

5.7

2.1

0.91

3.6

1.2

0.61

$\begin{array}{lll}8.1 & 2.8 & 1.4\end{array}$

$\begin{array}{lll}0.63 & 0.25 & 0.14\end{array}$

$\begin{array}{lll}0.45 & 0.14 & 0.12\end{array}$

8.5

5.6

13

1.3

1.2

0.07

0.66

0.07

0.65

44

$<0.10$

0.00

66

0.70

9.1

0.03

0.33

0.12

8.0

0.02

0.28

0.09

5.0

0.03

4.8

$<0.02$

7,800

200

3,400

2,600

80

1

49

49

68

49

68

68

95

95

95

95

46

46

95

49

94

95

68

68

38
11,000
150
80

42

2,500

8,400
11,000

$\begin{array}{rr}45,000 & 120 \\ 1,500 & 20 \\ 17 & <1 \\ 18 & <1 \\ 12 & <1\end{array}$

5
37

13
380

380
45

57,000

1,400

1,200

250

1,700

910

0.5

0.7

120

53

3,400

2,400

350

52,000

32,000

140 
Table 15. Statistical summary of discrete runoff sample data: Commercial catchment-Continued

\begin{tabular}{|c|c|c|c|c|c|c|c|}
\hline Property or constituent & $\begin{array}{l}\text { Number } \\
\text { of } \\
\text { samples }\end{array}$ & Mean & Median & $\begin{array}{l}\text { Standard } \\
\text { error } \\
\text { of mean }\end{array}$ & $\begin{array}{l}\text { Standard } \\
\text { deviation }\end{array}$ & Maximum & Minimum \\
\hline \multicolumn{8}{|l|}{ OXYGEN DEMAND $(\mathrm{mg} / \mathrm{L})$} \\
\hline Oxygen demand, chemical, & & & & & & & \\
\hline $0.25 \mathrm{~N}$ dichromate & 50 & 95 & 63 & 13 & 92 & 460 & 12 \\
\hline Oxygen demand, biochemical, & & & & & & & \\
\hline $\begin{array}{l}\text { carbonaceous, 5-day at } 20^{\circ} \mathrm{C} \\
\text { Oxygen demand, biochemical, }\end{array}$ & 44 & 8.4 & 5.6 & 1.2 & 7.0 & 30 & 2.7 \\
\hline carbonaceous, 20-day- & 44 & 13 & 7.7 & 2.0 & 13 & 64 & 3.4 \\
\hline \multicolumn{8}{|l|}{ PHYSICAL PROPERTIES } \\
\hline $\begin{array}{l}\text { Turbidity (NTU) } \\
\text { Solids, residue at } 180^{\circ} \mathrm{C} \text {, }\end{array}$ & 71 & 31 & 9.8 & 6.1 & 52 & 300 & 1.6 \\
\hline $\begin{array}{l}\text { dissolved (mg/L) } \\
\text { Solids, sum of constituents, }\end{array}$ & 87 & 143 & 39 & 24 & 244 & 1,010 & 1 \\
\hline dissolved $(\mathrm{mg} / \mathrm{L})$ & 88 & 78 & 29 & 10 & 91 & 413 & 9 \\
\hline Sediment, suspended & 94 & 264 & 57 & 59 & 571 & 3,720 & 2 \\
\hline \multicolumn{8}{|l|}{ ORGANICS } \\
\hline $\begin{array}{l}\text { Carbon, organic, dissolved } \\
\text { (mg/L as C) } \\
\text { Carbon, organic, suspended }\end{array}$ & 47 & 54 & 24 & 9 & 64 & 260 & 4 \\
\hline$(\mathrm{mg} / \mathrm{L}$ as $\mathrm{C})$ & 46 & 2.5 & 1.9 & 0.2 & 1.7 & 10 & 0.9 \\
\hline Cyanide, total (mg/L) & 6 & 0.01 & $<0.01$ & 0.00 & 0.00 & $<0.01$ & $<0.01$ \\
\hline $\begin{array}{l}\text { Cyanide, dissolved (mg/L) } \\
\text { Oil and grease, total recoverable, }\end{array}$ & 6 & 0.01 & $<0.01$ & 0.00 & 0.00 & $<0.01$ & $<0.01$ \\
\hline gravimetric $(\mathrm{mg} / \mathrm{L})$ & 18 & 4 & 3 & 1 & 6 & 26 & 0 \\
\hline Phenols, total recoverable $(\mu \mathrm{g} / \mathrm{L})$ & 9 & 22 & 17 & 5 & 15 & 52 & 6 \\
\hline \multicolumn{8}{|l|}{ Pesticides (total recoverable, $\mu g / L$ ) } \\
\hline 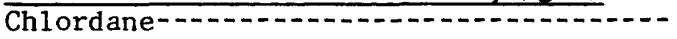 & 23 & 0.12 & 0.10 & 0.01 & 0.05 & 0.30 & $<0.10$ \\
\hline Diazinon- & 24 & 1.6 & 0.39 & 0.76 & 3.7 & 18 & 0.13 \\
\hline Dibromoch loropropane & 8 & 0.004 & $<0.003$ & 0.001 & 0.002 & 0.01 & $<0.003$ \\
\hline Endosulfan- & 24 & 0.01 & $<0.01$ & 0.00 & 0.01 & 0.07 & $<0.01$ \\
\hline 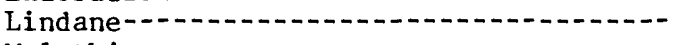 & 24 & 0.01 & 0.01 & 0.00 & 0.01 & 0.03 & 0.01 \\
\hline Malathion- & 24 & 0.28 & 0.23 & 0.05 & 0.25 & 1.4 & 0.08 \\
\hline Methyl parathion- & 24 & 0.01 & $<0.01$ & 0.00 & 0.00 & 0.03 & $<0.01$ \\
\hline Parathion- & 24 & 0.16 & 0.09 & 0.04 & 0.20 & 0.90 & $<0.01$ \\
\hline 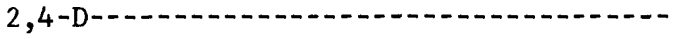 & 23 & 0.07 & 0.01 & 0.03 & 0.14 & 0.63 & $<0.01$ \\
\hline
\end{tabular}

Other organics analyzed but not detected

\begin{tabular}{|c|c|c|c|c|c|}
\hline $\begin{array}{c}\text { Organic } \\
\text { (total recoverable) }\end{array}$ & $\begin{array}{c}\text { Detection } \\
\text { limit } \\
(\mu g / L)\end{array}$ & $\begin{array}{l}\text { Number } \\
\text { of } \\
\text { samples }\end{array}$ & $\begin{array}{c}\text { Organic } \\
\text { (total recoverable) }\end{array}$ & $\begin{array}{c}\text { Detection } \\
\text { limit } \\
(\mu \mathrm{g} / \mathrm{L})\end{array}$ & $\begin{array}{l}\text { Number } \\
\text { of } \\
\text { samples }\end{array}$ \\
\hline Aldrin- & 0.01 & 24 & Heptachlor & 0.01 & 24 \\
\hline Benzene-1-n & 1 & 7 & Heptachlor epoxide-... & 0.01 & 24 \\
\hline Chlorobenzene- & 1 & 7 & Methomyl & 2 & 7 \\
\hline 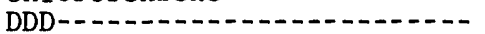 & 0.01 & 24 & Methoxychlor & 0.01 & 24 \\
\hline 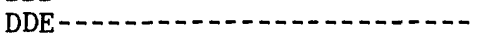 & 0.01 & *24 & Methyl trithion & 0.01 & 24 \\
\hline DDT- & 0.01 & 24 & Mirex- & 0.01 & 24 \\
\hline Dieldrin- & 0.01 & $* * 24$ & Perthane-c- & 0.1 & 24 \\
\hline Endrin-10 & 0.01 & 24 & Propham- & 2 & 7 \\
\hline Ethion- & 0.01 & 24 & Sevin- & 2 & 7 \\
\hline Ethylbenzene-.... & 1 & 7 & Silvex-chen & 0.01 & 23 \\
\hline Gross polychlorinated & & & Toxaphene-1. & 1 & 24 \\
\hline biphenyls & 0.1 & $\star \star * 24$ & Trithion- & 0.01 & 24 \\
\hline Gross polychlorinated & & & $2,4-\mathrm{DP} \ldots$ & 0.01 & 23 \\
\hline naphthalenes....... & 0.1 & 24 & $2,4,5-\mathrm{T} \cdots$ & 0.01 & 23 \\
\hline
\end{tabular}

*Twelve samples concentrations equal to the detection limit.

**One sample had a concentration equal to the detection limit.

***Two samples had concentrations equal to the detection limit. 
Table 16. Results of statistical comparison testing between catchments using discrete runoff quality data

Constituents for which no statistical difference $(\alpha=0.05)$ was determined for the listed catchments:

Industrial, single, multiple, commercial

Nitrogen, nitrate, dissolved

Cadmium, total recoverable and dissolved

Chromium, tota1 recoverable and dissolved

Nicke1, dissolved

Chlordane, total recoverable Diazinon, total recoverable Parathion, total recoverable Malathion, total recoverable 2,4-D, total recoverable Oil and grease, total recoverable Coliform, fecal

Industria1, commercia1

Mercury, tota1 recoverable

Industrial, single

Lindane, total recoverable

Industria1, multiple, commercial

Lead, dissolved
Single, multiple, commercial

Nitrogen, dissolved

Nitrogen, nitrite plus

nitrate, dissolved

Nitrogen, organic, dissolved

Nitrogen, ammonia, dissolved

Nitrogen, ammonia plus organic, total and dissolved

Magnesium, dissolved

Chloride, dissolved

Sulfate, dissolved

Arsenic, total and dissolved

Copper, dissolved

Mercury, dissolved

Zinc, total recoverable

Oxygen demand, chemica1

Industrial, multiple

Sediment, suspended

Iron, total recoverable

Multiple, commercial

Carbon, organic, dissolved

oxygen demand, biochemical, 5-day

oxygen demand, biochemical, 20-day

\section{Single, multiple}

Phosphorus, total and dissolved

Phosphorus, orthophosphate, tota 1 and dissolved

Specific conductance

Calcium, dissolved

Potassium, dissolved

Hardness, total

Solids, sum of constituents, dissolved

Solids, residue at $180^{\circ} \mathrm{C}$, dissolved

Turbidity

Alkalinity, tota1

Copper, total recoverable

Iron, dissolved

Lead total recoverable

Mercury, total recoverable

Zinc, dissolved

Carbon, organic, suspended

Industrial, single, multiple

Silica, dissolved

Nickel, total recoverable

Significant 1y different for al1 four catchments: ph and sodium, dissolved 
Table 17. Results of linear regression analysis using discrete runoff sample data

[Form of equation: $y=a+b x$ ]

\begin{tabular}{|c|c|c|c|c|c|c|}
\hline $\begin{array}{l}\text { Calculated constituent } \\
\text { concentration, in } \\
\text { milligrams per liter } \\
\text { (dependent variable, y) }\end{array}$ & $\begin{array}{l}\text { Regression } \\
\text { constant } \\
\text { (a) }\end{array}$ & $\begin{array}{l}\text { Regression } \\
\text { coeffi- } \\
\text { cient } \\
\text { (b) }\end{array}$ & $\begin{array}{l}\text { Constituent } \\
\text { concentration, in } \\
\text { micrograms per liter } \\
\text { or microsiemens per } \\
\text { centimeter at } 25^{\circ} \mathrm{C} \\
\text { (independent } \\
\text { variable, x) }\end{array}$ & $\begin{array}{l}\text { Adjusted } \\
\text { percent- } \\
\text { age of } \\
\text { variation } \\
\text { explained } \\
\left(\mathrm{R}^{2}\right)\end{array}$ & $\begin{array}{l}\text { Root } \\
\text { mean } \\
\text { square } \\
\text { error }\end{array}$ & $\begin{array}{l}\text { Number } \\
\text { of data } \\
\text { obser- } \\
\text { vations }\end{array}$ \\
\hline \multicolumn{7}{|c|}{ Single-dwelling residential catchment } \\
\hline Phosphorus, dissolved & -0.00419 & 0.006020 & Specific conductance & 87 & 0.110 & 57 \\
\hline $\begin{array}{l}\text { Phosphorus, dissolved } \\
\text { Phosphorus, dissolved }\end{array}$ & $\begin{array}{l}0.0134 \\
0.0137\end{array}$ & $\begin{array}{r}0.750 \\
1.17\end{array}$ & $\begin{array}{l}\text { Phosphorus, total } \\
\text { Phosphorus, ortho- } \\
\text { phosphate, dissolved }\end{array}$ & $\begin{array}{l}95 \\
95\end{array}$ & $\begin{array}{l}0.0722 \\
0.0678\end{array}$ & $\begin{array}{l}51 \\
55\end{array}$ \\
\hline $\begin{array}{l}\text { Nitrogen, ammonia, } \\
\text { dissolved }\end{array}$ & 0.00290 & 0.419 & $\begin{array}{l}\text { Nitrogen, ammonia plus } \\
\text { organic, dissolved }\end{array}$ & 96 & 0.307 & 48 \\
\hline $\begin{array}{l}\text { Nitrogen, ammonia plus } \\
\text { organic, dissolved }\end{array}$ & 0.339 & 0.648 & $\begin{array}{l}\text { Nitrogen, ammonia plus } \\
\text { organic, total }\end{array}$ & 68 & 0.859 & 40 \\
\hline $\begin{array}{l}\text { Nitrogen, ammonia plus } \\
\text { organic, dissolved }\end{array}$ & -0.772 & 0.0574 & $\begin{array}{l}\text { Specific conductance } \\
\text { (first rain season) }\end{array}$ & 92 & 0.455 & 28 \\
\hline $\begin{array}{l}\text { Nitrogen, ammonia plus } \\
\text { organic, dissolved }\end{array}$ & -0.0847 & 0.0754 & $\begin{array}{l}\text { Specific conductance } \\
\text { (second rain season) }\end{array}$ & 97 & 0.841 & 19 \\
\hline $\begin{array}{c}\text { Nitrogen, nitrite plus } \\
\text { nitrate, dissolved }\end{array}$ & 0.0772 & * & $\begin{array}{l}0.000226 \text { ( specific } \\
\text { conductance) }{ }^{2}- \\
0.000000584(\text { specific } \\
\text { conductance) }{ }^{3}\end{array}$ & 96 & 0.227 & 57 \\
\hline $\begin{array}{l}\text { Solids, sum of constit- } \\
\text { uents, dissolved }\end{array}$ & 6.84 & 0.576 & Specific conductance & 97 & 3.21 & 41 \\
\hline Oxygen demand, chemical & 36.1 & 1.48 & Specific conductance & 74 & 22.9 & 27 \\
\hline Alkalinity, total & 6.26 & 0.192 & Specific conductance & 78 & 4.85 & 57 \\
\hline \multicolumn{7}{|c|}{ Multiple-dwelling residential catchment } \\
\hline $\begin{array}{l}\text { Phosphorus, dissolved } \\
\text { Phosphorus, dissolved } \\
\text { Phosphorus, ortho- } \\
\text { phosphate, dissolved }\end{array}$ & $\begin{array}{r}0.0372 \\
0.00970 \\
0.0171\end{array}$ & $\begin{array}{r}0.00532 \\
0.756 \\
0.680\end{array}$ & $\begin{array}{l}\text { Specific conductance } \\
\text { Phosphorus, total } \\
\text { Phosphorus, dissolved }\end{array}$ & $\begin{array}{l}86 \\
36 \\
88\end{array}$ & $\begin{array}{l}0.122 \\
0.0713 \\
0.0879\end{array}$ & $\begin{array}{l}68 \\
50 \\
60\end{array}$ \\
\hline $\begin{array}{l}\text { Nitrogen, ammonia, } \\
\text { dissolved }\end{array}$ & 0.0190 & 0.389 & $\begin{array}{l}\text { Nitrogen, ammonia plus } \\
\text { organic, dissolved }\end{array}$ & 94 & 0.358 & 60 \\
\hline $\begin{array}{l}\text { Nitrogen, ammonia plus } \\
\text { organic, dissolved }\end{array}$ & -0.0499 & 0.890 & $\begin{array}{l}\text { Nitrogen, ammonia plus } \\
\text { organic, total }\end{array}$ & 90 & 0.482 & 49 \\
\hline $\begin{array}{l}\text { Nitrogen, ammonia plus } \\
\text { organic, dissolved }\end{array}$ & -0.705 & 0.0604 & Specific conductance & 95 & 0.837 & 59 \\
\hline $\begin{array}{l}\text { Nitrogen, nitrite plus } \\
\text { nitrate, dissolved }\end{array}$ & -0.382 & 0.0190 & Specific conductance & 95 & 0.257 & 68 \\
\hline $\begin{array}{l}\text { Solids, sum of constit- } \\
\text { uents, dissolved }\end{array}$ & 4.60 & 0.647 & Specific conductance & 99 & 5.20 & 53 \\
\hline Alkalinity, total & 3.54 & 0.239 & Specific conductance & 89 & 5.18 & 70 \\
\hline \multicolumn{7}{|c|}{ **Commercial catchment } \\
\hline Phosphorus, dissolved & 0.00920 & 0.00377 & Specific conductance & 93 & 0.0278 & 34 \\
\hline $\begin{array}{l}\text { Phosphorus, dissolved } \\
\text { Phosphorus, dissolved }\end{array}$ & $\begin{array}{r}-0.0154 \\
0.0229\end{array}$ & $\begin{array}{r}0.916 \\
1.31\end{array}$ & $\begin{array}{l}\text { Phosphorus, total } \\
\text { Phosphorus, ortho- } \\
\text { phosphate, dissolved }\end{array}$ & $\begin{array}{l}93 \\
93\end{array}$ & $\begin{array}{l}0.0268 \\
0.0516\end{array}$ & $\begin{array}{l}35 \\
60\end{array}$ \\
\hline $\begin{array}{l}\text { Nitrogen, ammonia, } \\
\text { dissolved }\end{array}$ & 0.0331 & 0.547 & $\begin{array}{l}\text { Nitrogen, ammonia plus } \\
\text { organic, dissolved }\end{array}$ & 94 & 0.180 & 35 \\
\hline $\begin{array}{l}\text { Nitrogen, ammonia plus } \\
\text { organic, dissolved }\end{array}$ & 0.104 & 0.0481 & Specific conductance & 90 & 0.433 & 34 \\
\hline $\begin{array}{l}\text { Nitrogen, ammonia plus } \\
\text { organic, dissolved }\end{array}$ & 0.0432 & 0.860 & $\begin{array}{l}\text { Nitrogen, ammonia plus } \\
\text { organic, total }\end{array}$ & 96 & 0.260 & 35 \\
\hline $\begin{array}{l}\text { Nitrogen, nitrite plus } \\
\text { nitrate, dissolved }\end{array}$ & -0.0434 & 0.0167 & Specific conductance & 94 & 0.115 & 34 \\
\hline $\begin{array}{l}\text { Solids, sum of constit- } \\
\text { uents, dissolved }\end{array}$ & 9.89 & 0.465 & Specific conductance & 93 & 3.11 & 36 \\
\hline Alkalinity, total & 2.59 & 0.244 & Specific conductance & 80 & 6.89 & 62 \\
\hline
\end{tabular}

*Nonlinear relation; form of equation: $y=a+c x^{2}+d x^{3}$.

**Only first rain season data used because of construction activity during second season. 
Table 18. Constituent storm-runoff loads: Industrial catchment

[Time is beginning and end of runoff, in hours. Total runoff volume is depth in inches covering the catchment drainage area. EMC is event mean concentration of constituent, in milligrams per liter $(\mathrm{mg} / \mathrm{L})$ or micrograms per liter $(\mu \mathrm{g} / \mathrm{L})$, as noted. Event load is in pounds. $\mathrm{n}$ is number of samples used in computation of storm-runoff load. Composite samples are identified by a $C$. <, actual value is less than value shown]

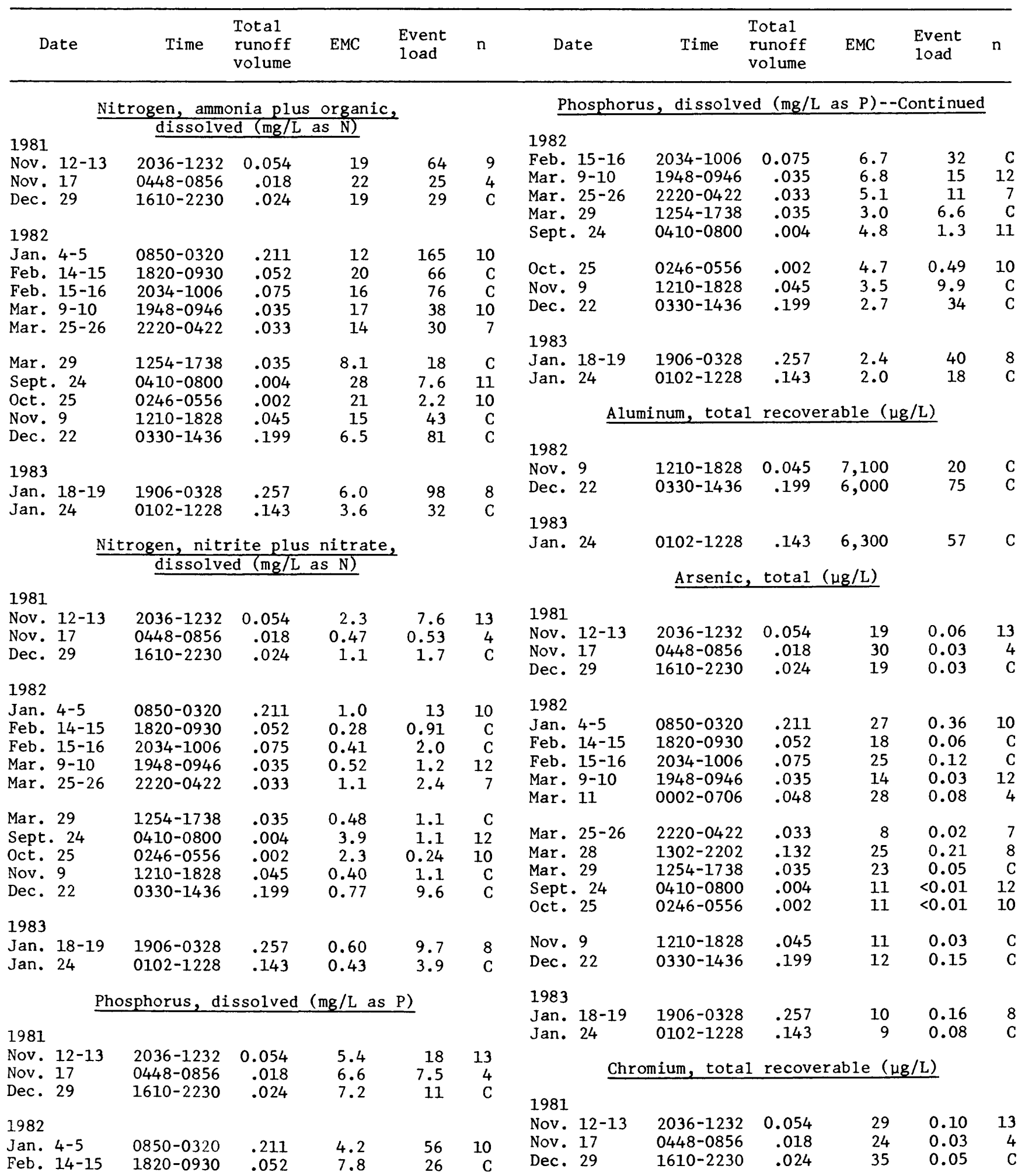


Table 18. Constituent storm-runoff loads: Industrial catchment-Continued

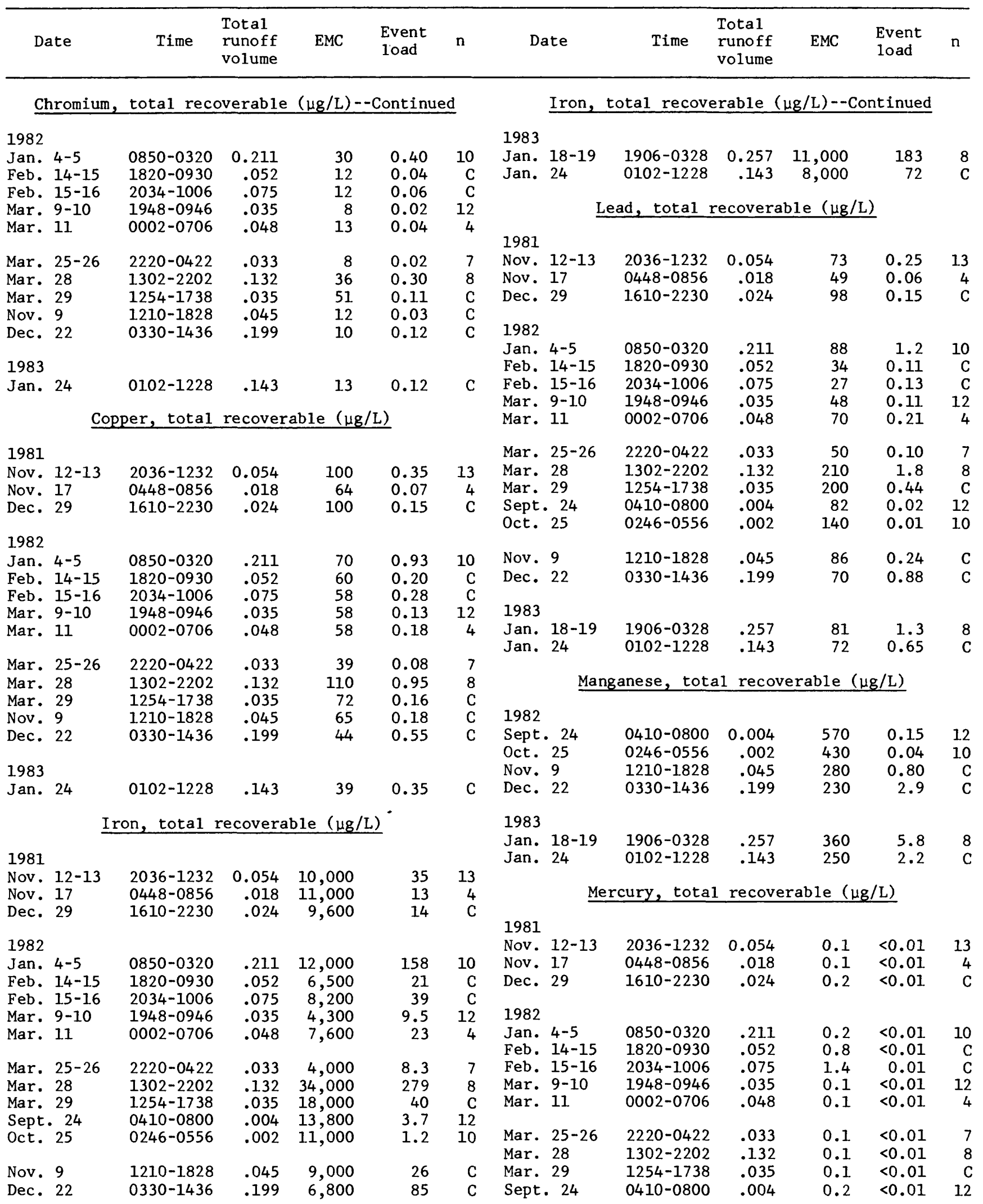


Table 18. Constituent storm-runoff loads: Industrial catchment-Continued

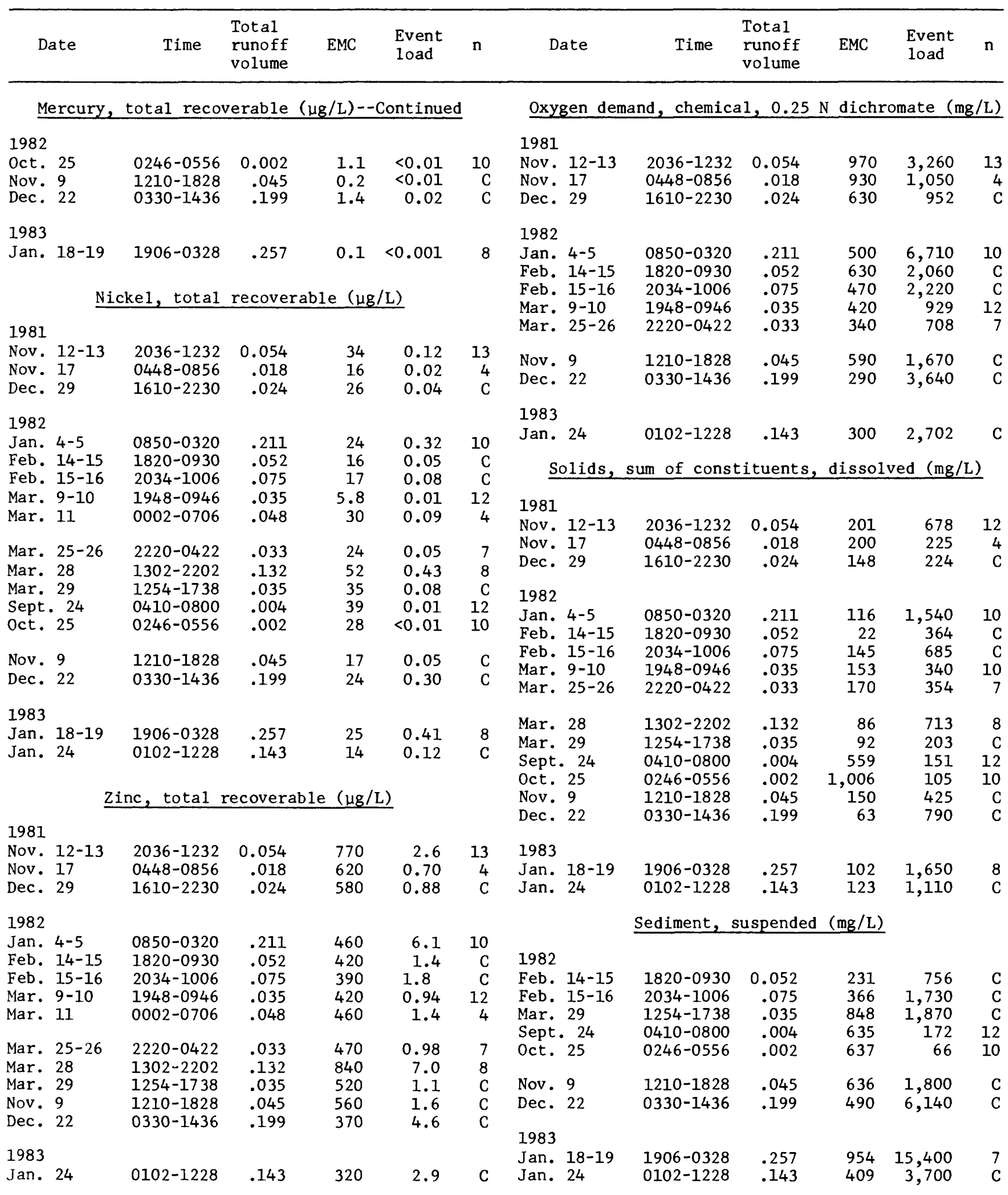


Table 18. Constituent storm-runoff loads: Industrial catchment-Continued

\begin{tabular}{|c|c|c|c|c|c|c|c|c|c|c|c|}
\hline Date & Time & $\begin{array}{l}\text { Total } \\
\text { runoff } \\
\text { volume }\end{array}$ & EMC & $\begin{array}{l}\text { Event } \\
\text { load }\end{array}$ & $\mathrm{n}$ & Date & Time & $\begin{array}{l}\text { Total } \\
\text { runoff } \\
\text { volume }\end{array}$ & EMC & $\begin{array}{l}\text { Event } \\
\text { load }\end{array}$ & $\mathrm{n}$ \\
\hline \multicolumn{6}{|c|}{ Carbon, organic, dissolved (mg/L) } & \multicolumn{6}{|c|}{ Carbon, organic, suspended (mg/L) } \\
\hline $\begin{array}{l}1981 \\
\text { Nov. } 12-13 \\
\text { Nov. } 17 \\
\text { Dec. } 29\end{array}$ & $\begin{array}{l}2036-1232 \\
0448-0856 \\
1610-2230\end{array}$ & $\begin{array}{r}0.054 \\
.018 \\
.024\end{array}$ & $\begin{array}{r}220 \\
87 \\
85\end{array}$ & $\begin{array}{r}751 \\
98 \\
128\end{array}$ & $\begin{array}{r}13 \\
4 \\
\mathrm{C}\end{array}$ & $\begin{array}{l}1981 \\
\text { Nov. } 12-13 \\
\text { Nov. } 17 \\
\text { Dec. } 29\end{array}$ & $\begin{array}{l}2036-1232 \\
0448-0856 \\
1610-2230\end{array}$ & $\begin{array}{r}0.054 \\
.018 \\
.024\end{array}$ & $\begin{array}{l}28 \\
40 \\
28\end{array}$ & $\begin{array}{l}96 \\
45 \\
42\end{array}$ & $\begin{array}{r}13 \\
3 \\
\mathrm{C}\end{array}$ \\
\hline $\begin{array}{l}1982 \\
\text { Jan. } 4-5 \\
\text { Feb. 14-15 } \\
\text { Feb. 15-16 } \\
\text { Mar. } 9-10 \\
\text { Mar. } 25-26\end{array}$ & $\begin{array}{l}0850-0320 \\
1820-0930 \\
2034-1006 \\
1948-0946 \\
2220-0422\end{array}$ & $\begin{array}{l}.211 \\
.052 \\
.075 \\
.035 \\
.033\end{array}$ & $\begin{array}{r}72 \\
230 \\
86 \\
220 \\
200\end{array}$ & $\begin{array}{l}962 \\
753 \\
406 \\
480 \\
409\end{array}$ & $\begin{array}{r}10 \\
\mathrm{C} \\
\mathrm{C} \\
12 \\
7\end{array}$ & $\begin{array}{l}1982 \\
\text { Jan. } 4-5 \\
\text { Feb. } 14-15 \\
\text { Feb. } 15-16 \\
\text { Mar. } 9-10 \\
\text { Mar. 25-26 }\end{array}$ & $\begin{array}{l}0850-0320 \\
1820-0930 \\
2034-1006 \\
1948-0946 \\
2220-0422\end{array}$ & $\begin{array}{l}.211 \\
.052 \\
.075 \\
.035 \\
.033\end{array}$ & $\begin{array}{l}35 \\
22 \\
22 \\
21 \\
10\end{array}$ & $\begin{array}{r}468 \\
72 \\
104 \\
47 \\
20\end{array}$ & $\begin{array}{r}10 \\
\mathrm{C} \\
\mathrm{C} \\
12 \\
7\end{array}$ \\
\hline $\begin{array}{ll}\text { Mar. } & 29 \\
\text { Nov. } & 9 \\
\text { Dec. } & 22\end{array}$ & $\begin{array}{l}1254-1738 \\
1210-1828 \\
0330-1436\end{array}$ & $\begin{array}{l}.035 \\
.045 \\
.199\end{array}$ & $\begin{array}{r}750 \\
60 \\
20\end{array}$ & $\begin{array}{r}1,700 \\
170 \\
251\end{array}$ & $\begin{array}{l}\mathrm{C} \\
\mathrm{C} \\
\mathrm{C}\end{array}$ & $\begin{array}{ll}\text { Mar. } 29 \\
\text { Nov. } 9 \\
\text { Dec. } 22\end{array}$ & $\begin{array}{l}1254-1738 \\
1210-1828 \\
0330-1436\end{array}$ & $\begin{array}{l}.035 \\
.045 \\
.199\end{array}$ & $\begin{array}{l}36 \\
38 \\
22\end{array}$ & $\begin{array}{r}80 \\
108 \\
276\end{array}$ & $\begin{array}{l}\mathrm{C} \\
\mathrm{C} \\
\mathrm{C}\end{array}$ \\
\hline $\begin{array}{l}1983 \\
\text { Jan. } 24\end{array}$ & $0102-1228$ & .143 & 24 & 216 & $\mathrm{C}$ & & & & & & \\
\hline
\end{tabular}

Table 19. Constituent storm-runoff loads: Single-dwelling residential catchment

[Time is beginning and end of runoff, in hours. Total runoff volume is depth in inches covering the catchment drainage area. EMC is event mean concentration of constituent, in milligrams per liter $(\mathrm{mg} / \mathrm{L})$ or micrograms per liter $(\mu \mathrm{g} / \mathrm{L})$, as noted. Event load is in pounds. $n$ is number of samples used in computation of storm-runoff load. Sample concentrations were determined by laboratory analyses except where noted by an e, which indicates sample concentration were estimated using a regression equation. Composite samples are identified by a $C$. <, actual value is less than value shown]

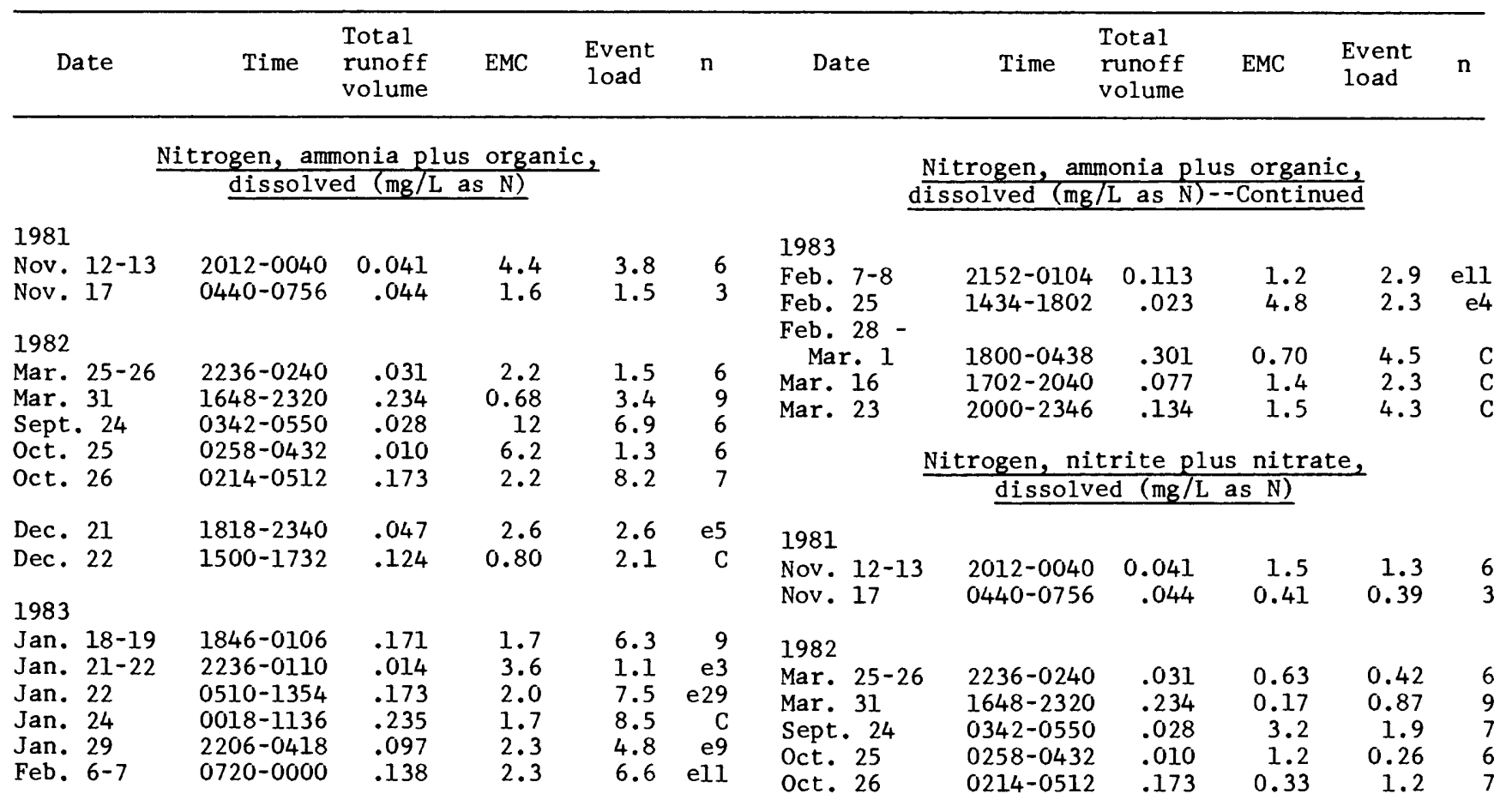


Table 19. Constituent storm-runoff loads: Single-dwelling residential catchment-Continued

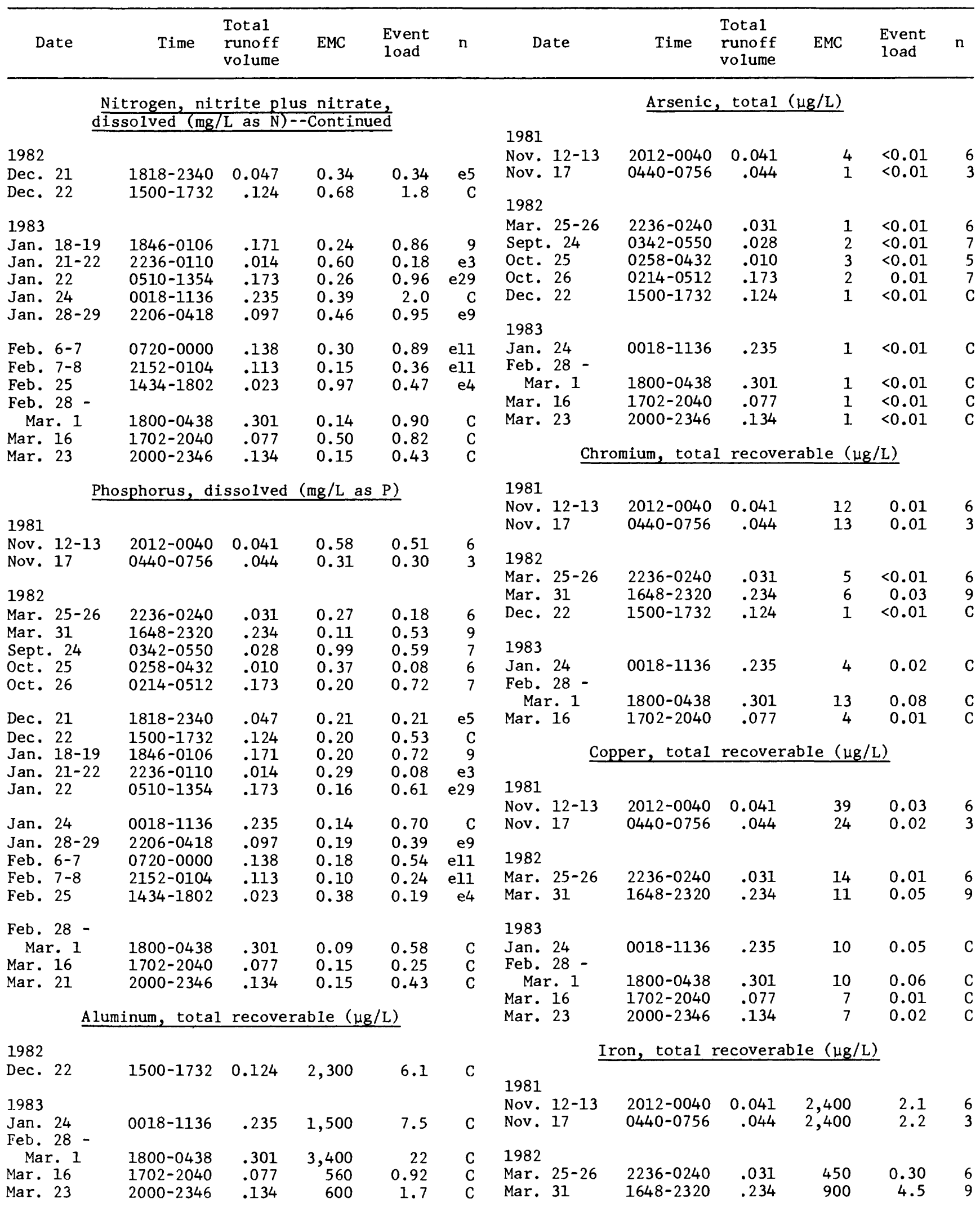


Table 19. Constituent storm-runoff loads: Single-dwelling residential catchment-Continued

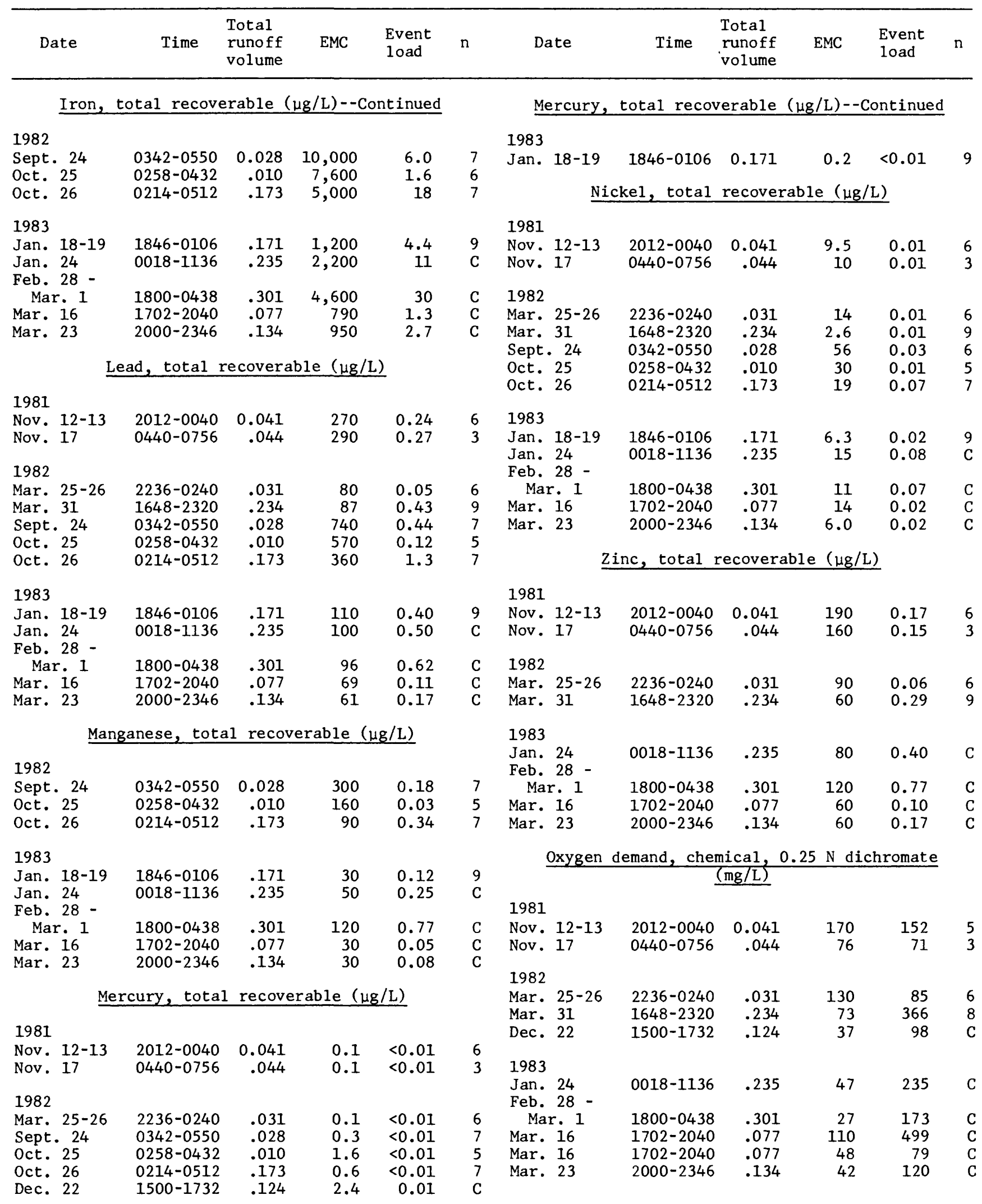


Table 19. Constituent storm-runoff loads: Single-dwelling residential catchment-Continued

\begin{tabular}{|c|c|c|c|c|c|c|c|c|c|c|c|}
\hline Date & Time & $\begin{array}{l}\text { Total } \\
\text { runoff } \\
\text { volume }\end{array}$ & EMC & $\begin{array}{l}\text { Event } \\
\text { load }\end{array}$ & $\mathrm{n}$ & Date & Time & $\begin{array}{l}\text { Total } \\
\text { runoff } \\
\text { volume }\end{array}$ & EMC & $\begin{array}{l}\text { Event } \\
\text { load }\end{array}$ & $\mathrm{n}$ \\
\hline \multicolumn{6}{|c|}{ Solids, sum of constituents, dissolved (mg/L) } & \multicolumn{6}{|c|}{ Sediment, suspended (mg/L)--Continued } \\
\hline 1981 & & & & & & 1983 & & & & & \\
\hline $\begin{array}{l}\text { Nov. } 12-13 \\
\text { Nov. } 17\end{array}$ & $\begin{array}{l}2012-0040 \\
0440-0756\end{array}$ & $\begin{array}{r}0.041 \\
.044\end{array}$ & $\begin{array}{l}60 \\
38\end{array}$ & $\begin{array}{l}52 \\
36\end{array}$ & $\begin{array}{l}6 \\
3\end{array}$ & $\begin{array}{l}\text { Jan. } 18-19 \\
\text { Jan. } 24 \\
\text { Feb. } 28-\end{array}$ & $\begin{array}{l}1846-0106 \\
0018-1136\end{array}$ & $\begin{array}{r}0.171 \\
.235\end{array}$ & $\begin{array}{l}43 \\
71\end{array}$ & $\begin{array}{l}156 \\
355\end{array}$ & $\begin{array}{l}9 \\
\mathrm{C}\end{array}$ \\
\hline 1982 & & & & & & Mar. 1 & $1800-0438$ & .301 & 70 & 448 & $\mathrm{C}$ \\
\hline Mar. 25-26 & $2236-0240$ & .031 & 37 & 24 & 6 & Mar. 16 & $1702-2040$ & .077 & 36 & 59 & C \\
\hline Mar. 31 & $1648-2320$ & .234 & 18 & 91 & 9 & Mar. 23 & $2000-2346$ & .134 & 30 & 86 & $\mathrm{C}$ \\
\hline Sept. 24 & $0342-0550$ & .028 & 93 & 56 & 7 & & & & & & \\
\hline Oct. 25 & $0258-0432$ & .010 & 56 & 12 & 6 & \multirow{2}{*}{\multicolumn{5}{|c|}{ Carbon, organic, dissolved (mg/L) }} & \\
\hline Oct. 26 & $0214-0512$ & .173 & 23 & 85 & 7 & 1981 & & & & & \\
\hline Dec. 21 & $1818-2340$ & .047 & 27 & 27 & e5 & Nov. $12-13$ & $2012-0040$ & 0.041 & 76 & 66 & 6 \\
\hline Dec. 22 & $1500-1732$ & .124 & 15 & 40 & C & Nov. 17 & $0440-0756$ & .044 & 140 & 128 & 3 \\
\hline 1983 & & & & & & 1982 & & & & & \\
\hline Jan. $18-19$ & 1846-0106 & .171 & 21 & 77 & 9 & Mar. 25-26 & $2236-0240$ & .031 & 100 & 66 & 6 \\
\hline Jan. $21-22$ & $2236-0110$ & .014 & 35 & 10 & e3 & Mar. 31 & $1648-2320$ & .234 & 150 & 747 & 9 \\
\hline Jan. 22 & $0510-1354$ & .173 & 23 & 85 & e29 & Mar. 22 & $1500-1732$ & .124 & 50 & 132 & C \\
\hline Jan. 24 & 0018-1136 & .235 & 44 & 220 & C & & & & & & \\
\hline Jan. $28-29$ & $2206-0418$ & .097 & 25 & 52 & e9 & 1983 & & & & & \\
\hline Feb. 6-7 & $0720-0000$ & .138 & 25 & 73 & ell & Feb. $28-$ & $0010-1130$ & כנכ2 & 20 & 101 & C \\
\hline Feb. 7-8 & 2152-0104 & .113 & 17 & 40 & ell & Mar. 1 & $1800-0438$ & .301 & 4.4 & 28 & $\mathrm{C}$ \\
\hline Feb. 25 & $1434-1802$ & .023 & 44 & 22 & $\mathrm{e} 4$ & Mar. 16 & $1702-2040$ & .077 & 45 & 74 & C \\
\hline Feb. 28 - & & & & & & Mar. 23 & $2000-2346$ & .134 & 27 & 77 & C \\
\hline Mar. 1 & $1800-0438$ & .301 & 17 & 109 & C & & & & & & \\
\hline Mar. 23 & $2000-2346$ & .134 & 21 & 60 & C & \multicolumn{5}{|c|}{ Carbon, organic, suspended (mg/L) } & \\
\hline & & & & & & 1981 & & & & & \\
\hline & Sediment, & su spended & $(\mathrm{mg} / \mathrm{L})$ & & & Nov. $12-13$ & $2012-0040$ & 0.041 & 3.2 & 2.8 & 4 \\
\hline 1981 & & & & & & $\Delta$ & & & 3 & & 3 \\
\hline Nov. $12-13$ & $2012-0040$ & 0.041 & 106 & 93 & 6 & 1982 & & & & & \\
\hline Nov. 17 & $0440-0756$ & .044 & 216 & 202 & 3 & $\begin{array}{l}\text { Mar. 25-26 } \\
\text { Mar. } 31\end{array}$ & $\begin{array}{l}2236-0240 \\
1648-2320\end{array}$ & $\begin{array}{l}.031 \\
.234\end{array}$ & $\begin{array}{l}1.4 \\
1.5\end{array}$ & $\begin{array}{r}0.95 \\
7.7\end{array}$ & $\begin{array}{l}6 \\
9\end{array}$ \\
\hline 1982 & & & & & & Dec. 22 & $1500-1732$ & .124 & 5.0 & 13 & C \\
\hline Mar. 25-26 & $2236-0240$ & .031 & 22 & 14 & 6 & & & & & & \\
\hline Mar. 31 & $1648-2320$ & .234 & 36 & 178 & 9 & 1983 & & & & & \\
\hline Sept. 24 & $0342-0550$ & .028 & 538 & 321 & 7 & Feb. $28-$ & & & & & \\
\hline Oct. 25 & $0258-0432$ & .010 & 307 & 65 & 6 & Mar. 1 & $1800-0438$ & .301 & 1.9 & 12 & C \\
\hline Oct. 26 & $0214-0512$ & .173 & 392 & 1,440 & 7 & Mar. 16 & $1702-2040$ & .077 & 3.6 & 5.9 & C \\
\hline Dec. 22 & $1500-1732$ & .124 & 136 & 359 & C & Mar. 23 & $2000-2346$ & .134 & 2.3 & 6.6 & C \\
\hline
\end{tabular}


Table 20. Constituent storm-runoff loads: Multiple-dwelling residential catchment

[Time is beginning and end of runoff, in hours. Total runoff volume is depth in inches covering the catchment drainage area. EMC is event mean concentration of constituent, in milligrams per liter (mg/L) or micrograms per liter $(\mu \mathrm{g} / \mathrm{L})$, as noted. Event load is in pounds. $n$ is number of samples used in computation of storm-runoff load. Sample concentrations were determined by laboratory analyses except where noted by an e, which indicates sample concentrations were estimated using a regression equation. Composite samples are identified by a $C$. <, actual value is less than value shown]

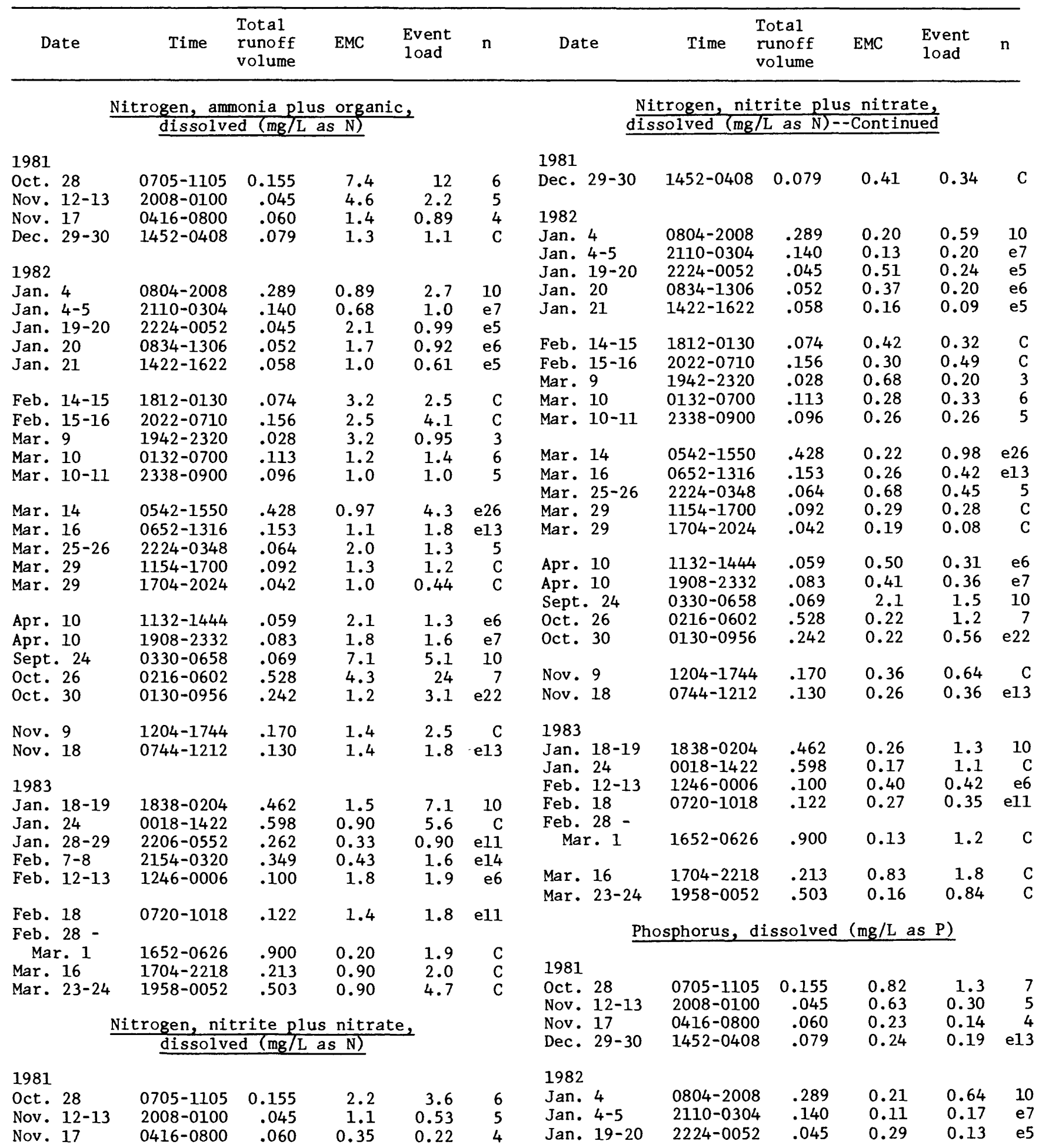


Table 20. Constituent storm-runoff loads: Multiple-dwelling residential catchment-Continued

\begin{tabular}{|c|c|c|c|c|c|c|c|c|c|c|c|}
\hline Date & Time & $\begin{array}{l}\text { Total } \\
\text { runoff } \\
\text { volume }\end{array}$ & EMC & $\begin{array}{l}\text { Event } \\
\text { load }\end{array}$ & $\mathrm{n}$ & Date & Time & $\begin{array}{l}\text { Total } \\
\text { runoff } \\
\text { volume }\end{array}$ & EMC & $\begin{array}{l}\text { Event } \\
\text { load }\end{array}$ & $\mathrm{n}$ \\
\hline
\end{tabular}

Phosphorus, dissolved (mg/L as P)--Continued

Arsenic, total $(\mu g / \mathrm{L})--$ Continued

1982

Jan. $20 \quad 0834-1306$

Jan. 21

Feb. 14-15

Feb. 15-16

Mar. 9

1422-1622

1812-0130

2022-0710

$1942-2320$

Mar. 10

0132-0700

Mar. 10-1.1

Mar. 14

2338-0900

0542-1550

0652-1.316

Mar. 16

Mar. 25-26

2224-0348

Mar. 29

$1154-1700$

Mar. 29

1.704-2024

1.132-1.444

Apr. 10

1908-2332

Apr. 10

0330-0658

Oct. 26

0216-0602

0130-0956

1204-1744

Nov. 9

Nov 18

0744-1.21.2

0.052

.058

.074

.156

.028

.113

.096

.428

.153

.064

0.25

0.19

0.43

0.14

0.32

0.14

0.11

0.33

0.12

0.23

0.15

0.16

0.23

0.22

0.10

0.14

0.23

0.65

0.26

0.15

.092

.042

.059

.083

.069

0.11

0.12

0.29

0.26
0.73

0.11

0.05

0.18

0.73

0.22
0.53

.528

.242

.170

0.19

0.21

0.20

1.1

0.52

0.22

0.36

0.30 el.3

1983

Jan. 18-19

Jan. 24

1838-0204

0018-1422

.462

0.32

$1.6 \quad 10$

Jan . 28-29

2206-0552

.598

.262

.349

Feb. 1.2-13

2154-0320

.100

0.08

0.13

0.14

C

0.50 el1

$0.26 \quad 0.27$ e6

Feb. 18

Mar. 1

0720-1018 .122

0.22

$0.28 \mathrm{ell}$

Mar. 1

1652-0626 .900

$1704-2218 \quad .213$

0.06

0.15

0.56

0.33

$0.08 \quad 0.42$

Mar. 23-24

$1958-0052 \quad .503$

\section{Aluminum, total recoverable $(\mu \mathrm{g} / \mathrm{L})$}

1982

$1204-1744$

0.170

2,800

5.0

C

1983

Jan. 24

Feb. 28 -

Mar. 1

Mar. 16

0018-14

1652-0626

$.598 \quad 4,400$

27

$.900 \quad 2,700$

$\begin{array}{lll}1704-2218 & .213 & 3,200\end{array}$

Arsenic, total ( $\mu g / L)$

1981.

oct. 28

0705-11.05

2008-0100

0.155

.045

Nov. 17

0416-0800

.060

Dec. 29-30

1452-0408

.079

1982

Feb. 14-15

1812-0130 .074

Feb. 15-16 2022-0710 .156

Mar. 10

$0132-0700$

.156

Mar. 29

$1154-1.700$

C

0.01

$<0.01$

$<0.01$

$<0.01$

1982

Mar. 29

Sept. 24

Nov. 9

0.042

.069

.528

.170

$1<0.01$

$4<0.01$

20.01

$<0.01$

1983

Jan. $18-19 \quad 1838-0204 \quad .462 \quad 1 \quad 0.01$

Feb. 28 -

Mar. $1.1652-0626 \quad .900$

Mar. $16 \quad 1704-2218 \quad .213$

Mar. 23-24 1958-0052 .503

$1 \quad 0.01$

$1 \quad<0.01$

$\mathrm{C}$
$\mathrm{C}$
$\mathrm{C}$

Chromium, total recoverable $(\mu \mathrm{g} / \mathrm{L})$

1981

Nov. $12-1.3$

Nov. 17

0705-1105

0.155

.045

.060

.079

12

0.02

Dec. $29-30$

0416-0800

21.

0.01

0.02

0.02

1982

Jan. 4

0804-2008

.289

22

0.07

Feb. 14-15

$1812-0130$

Feb. 15-16 2022-0710

Mar. $9 \quad 1942-2320$

.074

.156

10

0.01

Mar. 10

0132-0700

.028

.113

10

0.02

Mar. 10-11 2338-0900

.096

2224-0348

1154-1700

Mar. 29

1704-2024

.064

.092

.042

1204-1744 .170

$23 \quad 0.03$

Nov. 9

1983

Jan. 24

Feb. 28 -

Mar. 1

Mar. 16

Mar. 23

$\begin{array}{rrrrr}0018-1422 & .598 & 10 & 0.06 & \mathrm{C} \\ 1652-0626 & .900 & 8 & 0.08 & \mathrm{C} \\ 1704-2218 & .213 & 10 & 0.02 & \mathrm{C} \\ 1958-0052 & .503 & 6 & 0.03 & \mathrm{C}\end{array}$

Copper, total recoverable ( $\mu \mathrm{g} / \mathrm{L})$

1981

1981

Nov. 12-13

Nov. 17

Dec. $29-30$

0705-1105

0.155

100

0.17

2008-0100

0416-0800

.045

.060

35

0.02

0.02

0.02

6
5
4

1982

Jan. 4

0804-2008

.289

Feb. 14-15

1812-0130

Feb. 15-16

2022-0710

1942-2320

.074

.0756

.028

.113

2338-0900 .096

Mar. 10-11 
Table 20. Constituent storm-runoff loads: Multiple-dwelling residential catchment-Continued

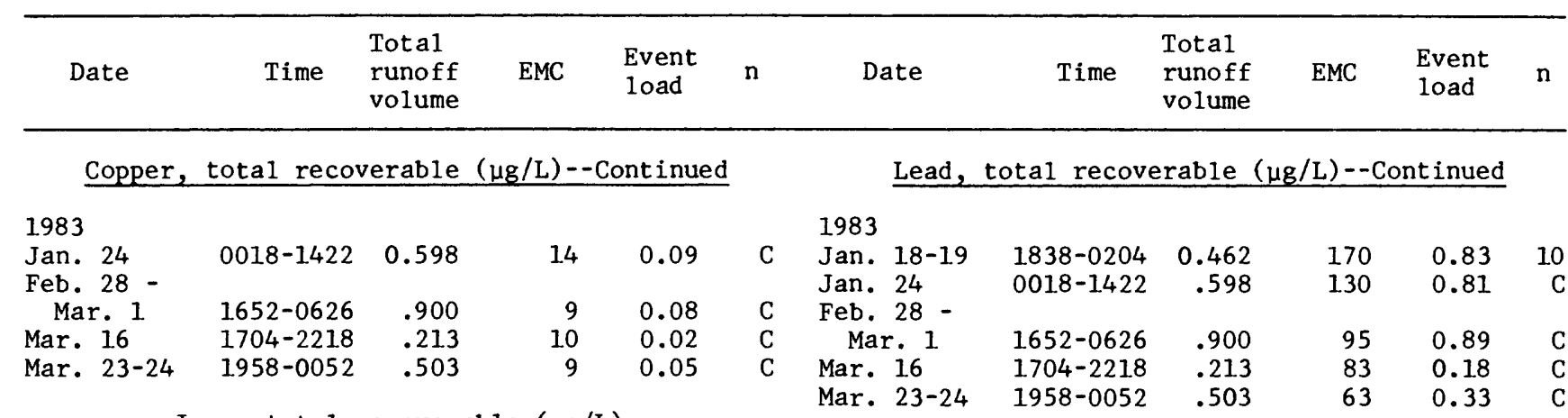

Iron, total recoverable ( $\mu \mathrm{g} / \mathrm{L})$

1981.

Oct. 28

Nov. $12-13$

Nov. 17

Dec. $29-30$

0705-1105

2008-0100

0416-0800

1452-0408

1982

Jan. 4

Feb. 14-15

Feb. 15-16

Mar. 9

Mar. 10

0804-2008

1812-0130

2022-0710

1942-2320

0132-0700

Mar. 10-11

Mar. 25-26

Mar. 29

Mar. 29

Sept. 24

Oct. 26

Nov. 9

2338-0900

2224-0348

$1154-1700$

1704-2024

0330-0658

$0.15533,000$

$.0457,000$

$.060 \quad 15,000$

$.079 \quad 9,400$

$.289 \quad 7,900$

$.0743,800$

$.1563,400$

$.0283,000$

$.11311,000$

$.0967,700$

$.0642,600$

$.0923,600$

$.0424,700$

$.06929,000$

0216-0602

$.528 \quad 27,000$

1.204-1744

$.170 \quad 3,600$

1983

Jan. $18-19$
Jan. 24

Feb. 28-

Mar. 1

Mar. 16

Mar. 23-24
1838-0204

$.462 \quad 5,400$

0018-1.422

1652-0626

1704-2218

1958-0052 $\begin{array}{ll}.462 & 5,400 \\ .598 & 6,000\end{array}$

$.900 \quad 3,800$

$.2134,100$

$.5032,500$

$\begin{array}{rr}54 & 6 \\ 3.3 & 5 \\ 9.4 & 4 \\ 7.7 & \mathrm{C}\end{array}$

Manganese, total recoverable $(\mu \mathrm{g} / \mathrm{L})$

1982

Sept. 24

Oct. 24

Nov. 9

0330-0658

0216-0602

0.069

.528

840

1.204-1744

.170

520

0.60

1983

$\begin{array}{rrlllllr}24 & 10 & \text { Jan. 18-19 } & 1838-0204 & .462 & 120 & 0.57 & 10 \\ 3.0 & \text { C } & \text { Jan. 24 } & 0018-1422 & .598 & 120 & 0.75 & \text { C } \\ 5.5 & \text { C } & \text { Feb. 28 } & & & & & \\ 0.88 & 3 & \text { Mar. 1 } & 1652-0626 & .900 & 90 & 0.84 & \text { C } \\ 13 & 5 & \text { Mar. 16 } & 1704-2218 & .213 & 90 & 0.20 & \text { C } \\ & & \text { Mar. 23-24 } & 1958-0052 & .503 & 60 & 0.32 & \text { C }\end{array}$

$7.7 \quad 5$

1.75

3.5 C

2.1

21

10

1981

Oct. 28

Mercury, total recoverable $(\mu \mathrm{g} / \mathrm{L})$

Nov. 12-13

1489 Nov. 17

$0705-1105$

2008-0100

0416-0800

6.4 C

Dec. 29-30

1452-0408

0.155

.045

$0.8<0.01$

.060

$0.5<0.01$

1982

$26 \quad 10 \quad$ Jan. 4

0804-2008

.079

$0.2<0.01$

Jan. 4 -15 $1804-20$

.289

$0.2<0.01$

.074

.156

$1.3<0.01$

Feb. 15-16 2022-0710

36 C Mar. 9 1942-2320

9.1

Mar. 9

$0132-0700$

.028

$0.7<0.01$

.113

$0.3<0.01$

$0.3<0.01$

Mar. 10-11

2338-0900

.096

$0.2<0.01$

Mar. 25-26

2224-0348

Mar. 29

Mar. 29

1981

Oct. 28

$0705-1105$

Nov. 12-13

2008-0100

0.155

.045

Nov. 17

0416-0800

.060

.079

670

$$
150
$$

Dec. 29-30

$1452-0408$

240

1.1

Sept. 24

oct. 26

Nov. 9

$11.54-1.700$

1.704-2024

.064

.092

$0.2<0.01$

.042

$0.1<0.01$

$0.1<0.01$

0330-0658

.069

$0.6<0.01$

0216-0602 .528

1204-1744 .170

$0.4<0.01$

$0.2<0.01$

1983

Jan. 4

Feb. 14-15

0804-2008

\section{.289}

1812-0130

.074

220

Feb. 15-16

2022-0710

.156

Mar. 9

Mar. 10

1942-2320

.028

.113

170

89

120

350

0.13

Jan. 18-19

Feb. $28-$

0.043 Mar. 1

0.41

230

0.23

\section{.096}

2224-0348 .064

1154-1700

.092

.042

80
110

0.05

140

490

0.11

$\begin{array}{lr}0.06 & \mathrm{C} \\ 0.35 & 10\end{array}$

0330-0658 .069

Oct. 26

0216-0602

.528

260

1.59

1204-1.744 .170 1.20

0.21

5
5
$C$
$C$
0
9

Nov. 29
Jan. 24

Mar. 16

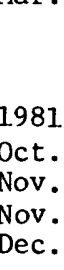

Oct. 28

Nov. 12-13

1838-0204

$1838-0204$
$0018-1422$

.462

$0.2<0.01$

1652-0626

Nickel, total recoverable $(\mu \mathrm{g} / \mathrm{L})$

0705-1105 0.155

2008-0100

0416-0800

1452-0408
Dec. 29-30

$1704-2218$
120

24

24
18

0.19

0.01

0.01

0.02
0.02

120


Table 20. Constituent storm-runoff loads: Multiple-dwelling residential catchment-Continued

\begin{tabular}{|c|c|c|c|c|c|c|c|c|c|c|c|}
\hline Date & Time & $\begin{array}{l}\text { Total } \\
\text { runoff } \\
\text { volume }\end{array}$ & EMC & $\begin{array}{l}\text { Event } \\
\text { load }\end{array}$ & $\mathrm{n}$ & Date & Time & $\begin{array}{l}\text { Total } \\
\text { runoff } \\
\text { volume }\end{array}$ & EMC & $\begin{array}{l}\text { Event } \\
\text { load }\end{array}$ & $\mathrm{n}$ \\
\hline \multicolumn{6}{|c|}{ Nickel, total recoverable $(\mu g / L)--$ Continued } & \multicolumn{6}{|c|}{$\frac{\text { Oxygen demand, chemica1, } 0.25 \mathrm{~N} \text { dichromate }}{\text { (mg/L)--Continued }}$} \\
\hline \multicolumn{12}{|l|}{1982} \\
\hline $\begin{array}{l}\text { Jan. } 4 \\
\text { Feb. } 14-15\end{array}$ & $\begin{array}{l}0804-2008 \\
1812-0130\end{array}$ & $\begin{array}{r}0.289 \\
.074\end{array}$ & $\begin{array}{l}17 \\
14\end{array}$ & $\begin{array}{l}0.05 \\
0.01\end{array}$ & $\begin{array}{r}10 \\
C\end{array}$ & $\begin{array}{l}1982 \\
\text { Jan. } 4\end{array}$ & $0804-2008$ & 0.289 & 54 & 163 & \\
\hline $\begin{array}{l}\text { Feb. } 14-15 \\
\text { Feb. } 15-16\end{array}$ & $2022-0710$ & .074 & 11 & 0.01 & $\mathrm{C}$ & Feb. 14-15 & $1812-0130$ & .074 & 110 & $\begin{array}{r}163 \\
85\end{array}$ & $\begin{array}{r}10 \\
\mathrm{C}\end{array}$ \\
\hline Mar. 9 & $1942-2320$ & .028 & 5 & $<0.01$ & 3 & Feb. $15-16$ & $2022-0710$ & .156 & 49 & 80 & $\mathrm{C}$ \\
\hline Mar. 10 & $0132-0700$ & .113 & 10 & 0.01 & 5 & $\begin{array}{l}\text { Mar. } 9 \\
\text { Mar. } 10\end{array}$ & $\begin{array}{l}1942-2320 \\
0132-0700\end{array}$ & $\begin{array}{l}.028 \\
.113\end{array}$ & $\begin{array}{r}110 \\
80\end{array}$ & $\begin{array}{l}31 \\
95\end{array}$ & $\begin{array}{l}3 \\
6\end{array}$ \\
\hline Mar. $10-11$ & $2338-0900$ & .096 & 19 & .02 & 5 & & & & & & \\
\hline Mar. 25-26 & $2224-0348$ & .064 & 21 & 0.01 & 5 & Mar. $10-11$ & $2338-0900$ & .096 & 96 & 97 & 5 \\
\hline Mar. 29 & $1154-1700$ & .092 & 10 & 0.01 & $\mathrm{C}$ & Mar. 25-26 & $2224-0348$ & .064 & 110 & 73 & 5 \\
\hline Mar. 29 & $1704-2024$ & .042 & 13 & 0.01 & $\mathrm{C}$ & Mar. 29 & $1154-1700$ & .092 & 71 & 68 & C \\
\hline Sept. 24 & $0330-0658$ & .069 & 110 & 0.08 & 10 & $\begin{array}{l}\text { Mar. } 29 \\
\text { Nov. } 9\end{array}$ & $\begin{array}{l}1704-2024 \\
1204-1744\end{array}$ & $\begin{array}{l}.042 \\
.170\end{array}$ & $\begin{array}{l}68 \\
77\end{array}$ & $\begin{array}{r}30 \\
137\end{array}$ & $\begin{array}{l}\mathrm{C} \\
\mathrm{C}\end{array}$ \\
\hline 0ct. 26 & $0216-0602$ & .528 & 82 & 0.45 & 9 & & & & & & \\
\hline Nov. 9 & $1204-1744$ & .170 & 13 & 0.02 & $\mathrm{C}$ & $\begin{array}{l}1983 \\
\text { Jan. } 24\end{array}$ & $0018-1422$ & .598 & 56 & 350 & C \\
\hline $\begin{array}{l}1983 \\
\text { Jan. }\end{array}$ & 4 & .462 & 20 & 0 & & $\begin{array}{l}\text { Feb. } 28- \\
\text { Mar. } 1\end{array}$ & & 0 & 43 & & \\
\hline $\begin{array}{ll}\text { Jan. } 24 \\
\text { Feb. } 28-\end{array}$ & $0018-$ & .598 & 20 & 10 & $\mathrm{C}$ & Mar. 16 & $\begin{array}{l}1652-0626 \\
1704-2218 \\
1958-005 ?\end{array}$ & .213 & $\begin{array}{r}110 \\
38\end{array}$ & $\begin{array}{l}404 \\
245 \\
200\end{array}$ & C \\
\hline Mar. 1 & $1652-0626$ & .900 & 13 & 0.12 & $\mathrm{C}$ & & & & & & \\
\hline $\begin{array}{l}\text { Mar. } 16 \\
\text { Mar. } 23\end{array}$ & $\begin{array}{l}1704-2218 \\
1958-0052\end{array}$ & .213 & $\begin{array}{l}24 \\
10\end{array}$ & $\begin{array}{l}0.05 \\
0.05\end{array}$ & $\begin{array}{l}\mathrm{C} \\
\mathrm{C}\end{array}$ & \multicolumn{6}{|c|}{$\frac{\text { Solids, sum of constituents, }}{\text { dissolved (mg/L) }}$} \\
\hline \multicolumn{6}{|c|}{ Zinc, total recoverable $(\mu g / L)$} & $\begin{array}{l}1981 \\
\text { Oct. } 28\end{array}$ & $0705-1105$ & 55 & 83 & 135 & 6 \\
\hline 1981 & & & & & & Nov. $12-13$ & $2008-0100$ & .045 & 74 & 35 & 5 \\
\hline 0ct. 28 & $0705-1105$ & 0.155 & 1,100 & 1.7 & 6 & Nov. 17 & $0416-0800$ & .060 & 38 & 24 & 4 \\
\hline Nov. $12-13$ & $2008-0100$ & .045 & 240 & 0.11 & 5 & Dec. $29-30$ & $1452-0408$ & .079 & 35 & 29 & $\mathrm{C}$ \\
\hline Nov. 17 & $0416-0800$ & .060 & 230 & 0.14 & 4 & 1982 & & & & & \\
\hline \multirow[t]{2}{*}{ Dec. $29-30$} & $1452-0408$ & .079 & 220 & 0.18 & C & Jan. 4 & $0804-2008$ & .289 & 27 & 81 & 10 \\
\hline & & & & & & Jan. 4- & $2110-0304$ & .140 & 21 & 30 & e7 \\
\hline Jan. 4 & $0804-2008$ & .289 & 190 & 0.58 & 10 & $\begin{array}{l}\text { Jan. } 19-20 \\
\text { Jan. } 20\end{array}$ & $\begin{array}{l}4-0052 \\
+-1306\end{array}$ & $\begin{array}{l}.045 \\
.052\end{array}$ & $\begin{array}{l}35 \\
30\end{array}$ & $\begin{array}{l}16 \\
16\end{array}$ & $\begin{array}{l}e 5 \\
e 6\end{array}$ \\
\hline Feb. $14-15$ & $1812-0130$ & .074 & 170 & 0.13 & $\mathrm{C}$ & Jan. 21 & $1422-1622$ & .058 & 23 & 14 & e5 \\
\hline $\begin{array}{l}\text { Feb. } 15-16 \\
\text { Mar. } 9\end{array}$ & $\begin{array}{l}2022-0710 \\
1942-2320\end{array}$ & .156 & 110 & 0.18 & C & & & & & & \\
\hline $\begin{array}{ll}\text { Mar. } 9 \\
\text { Mar. } 10\end{array}$ & $\begin{array}{l}1942-2320 \\
0132-0700\end{array}$ & .028 & 150 & 0.04 & 3 & Feb. $14-15$ & $1812-0130$ & .074 & 40 & 31 & C \\
\hline & $0132-0700$ & 13 & 291 & 0 . & 5 & Feb. 15-16 & $2022-0710$ & .156 & 30 & 4 & C \\
\hline Mar. 10-11 & $2338-0900$ & .096 & 170 & 0.17 & 5 & $\begin{array}{l}\text { Mar. } 9 \\
\text { Mar. } 10\end{array}$ & 10 & & 24 & 3 & $\begin{array}{l}3 \\
3\end{array}$ \\
\hline Mar. 25-26 & $2224-0348$ & .064 & 120 & 0.0 & 5 & Mar. 10-11 & $\begin{array}{l}0132-0 / 00 \\
2338-0900\end{array}$ & $\begin{array}{l}.113 \\
.096\end{array}$ & $\begin{array}{l}24 \\
28\end{array}$ & $\begin{array}{l}20 \\
29\end{array}$ & 5 \\
\hline $\begin{array}{l}\text { Mar. } 29 \\
\text { Mar. } 29\end{array}$ & $1154-1700$ & .092 & 110 & 0.1 & C & & & & & & \\
\hline $\begin{array}{l}\text { Mar. } 29 \\
\text { Nov. } 9\end{array}$ & 1704-2024 & .042 & 110 & 0.05 & $\mathrm{C}$ & Mar. 14 & $0542-1550$ & .428 & 24 & 106 & e26 \\
\hline \multirow[t]{2}{*}{ Nov. 9} & $1204-1744$ & 170 & 7 & 0 & $\mathrm{C}$ & Mar. 16 & $0652-1316$ & .153 & 25 & 41 & e13 \\
\hline & & & & & & $\begin{array}{l}\text { Mar. } 25-26 \\
\text { Mar. } 29\end{array}$ & $\begin{array}{l}2224-0348 \\
1154-1700\end{array}$ & .064 & $\begin{array}{l}34 \\
40\end{array}$ & $\begin{array}{l}22 \\
38\end{array}$ & $\begin{array}{l}5 \\
\mathrm{C}\end{array}$ \\
\hline \multirow{5}{*}{$\begin{array}{l}\text { Feb. } 28- \\
\text { Mar. } 1 \\
\text { Mar. } 16 \\
\text { Mar. } 23-24\end{array}$} & $0018-1422$ & .598 & 120 & 0.75 & C & Mar. 29 & $1704-2024$ & .042 & 30 & 13 & el1 \\
\hline & $1652-0626$ & .900 & 80 & 0.75 & $\mathrm{C}$ & Apr. 1 & 4 & & & & e6 \\
\hline & $1704-2218$ & .213 & 140 & 0.31 & C & Apr. 10 & $1908-2332$ & .083 & 32 & 27 & e7 \\
\hline & $1958-0052$ & .503 & 70 & 0.37 & C & Sept. 24 & $0330-0658$ & .069 & 82 & 58 & 10 \\
\hline & & & & & & Oct. 26 & $0216-0602$ & .528 & 30 & 164 & 9 \\
\hline Oxygen & emand, chem & $\frac{\mathrm{ical}, \quad 0}{\mathrm{mg} / \mathrm{L})}$ & $\mathrm{N}$ di & romate & & Oct. 30 & $0130-0956$ & .242 & 25 & 64 & e22 \\
\hline & & & & & & Nov. 9 & -1744 & .1 & 27 & 48 & C \\
\hline Oct. 28 & 105 & 0.15 & $4 / 0$ & 15 & 8 & & 2 & & 7 & & 13 \\
\hline Nov. $12-13$ & $2008-0100$ & .045 & 180 & 84 & 5 & 1983 & & & & & \\
\hline Nov. 17 & $0416-0800$ & .060 & 74 & 46 & 4 & Jan. 18 & $1838-0204$ & .462 & 27 & 129 & 10 \\
\hline Dec. $29-30$ & $1452-0408$ & .079 & 100 & 83 & $\mathrm{C}$ & Jan. 24 & $0018-1422$ & .598 & 24 & 150 & $\Gamma$ \\
\hline
\end{tabular}


Table 20. Constituent storm-runoff loads: Multiple-dwelling residential catchment-Continued

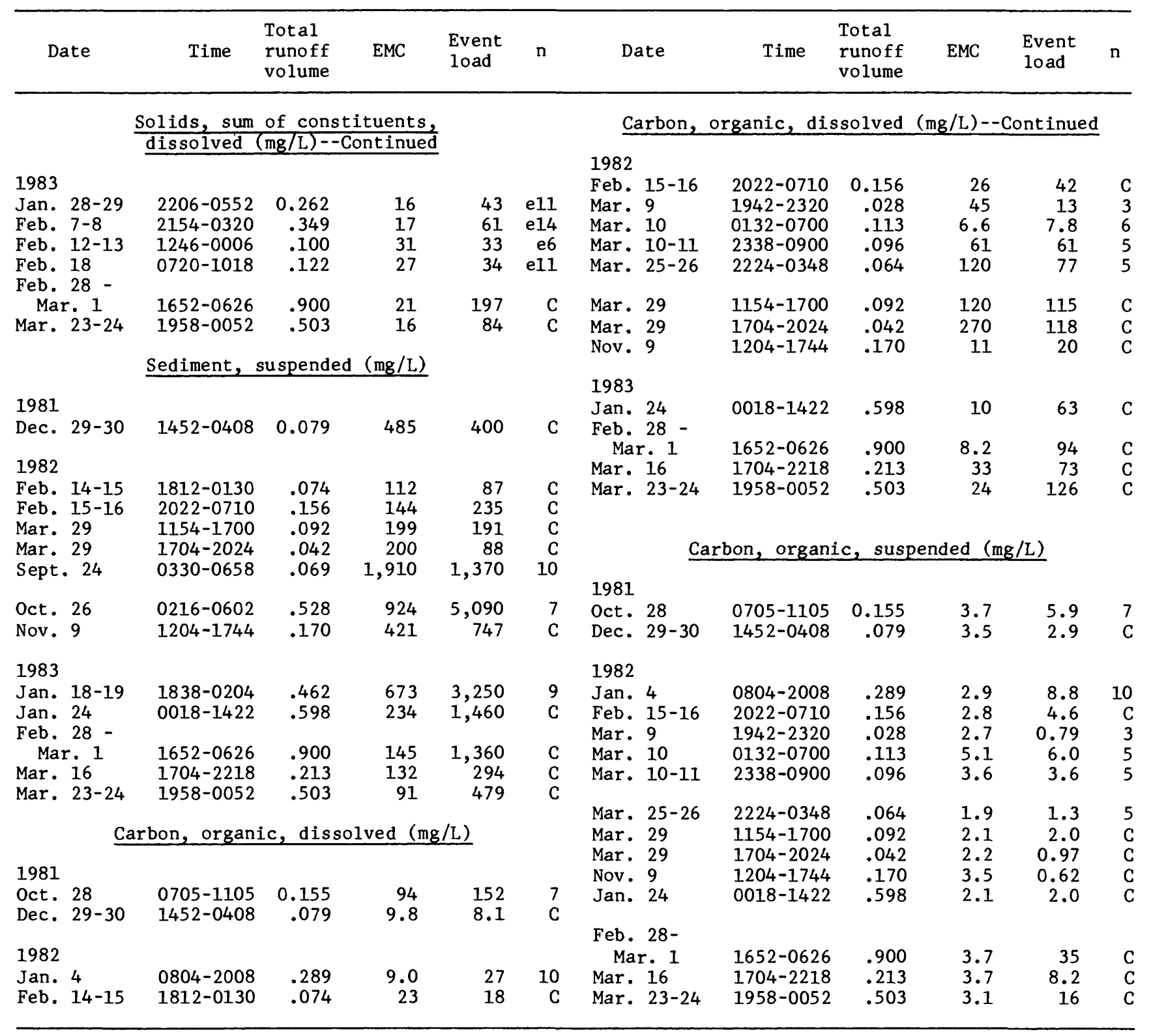


Table 21. Constituent storm-runoff loads: Commercial catchment

[Time is beginning and end of runoff, in hours. Total runoff volume is depth in inches covering the catchment drainage area. EMC is event mean concentration of constituent, in milligrams per liter $(\mathrm{mg} / \mathrm{L})$ or micrograms per liter $(\mu \mathrm{g} / \mathrm{L})$, as noted. Event load is in pounds. $n$ is number of samples used in computation of storm-runoff load. Sample concentrations were determined by laboratory analyses except where noted by an $e$, which indicates sample concentration were estimated using a regression equation. Composite samples are identified by a $\mathrm{C}$. <, actual value is less than value shown]

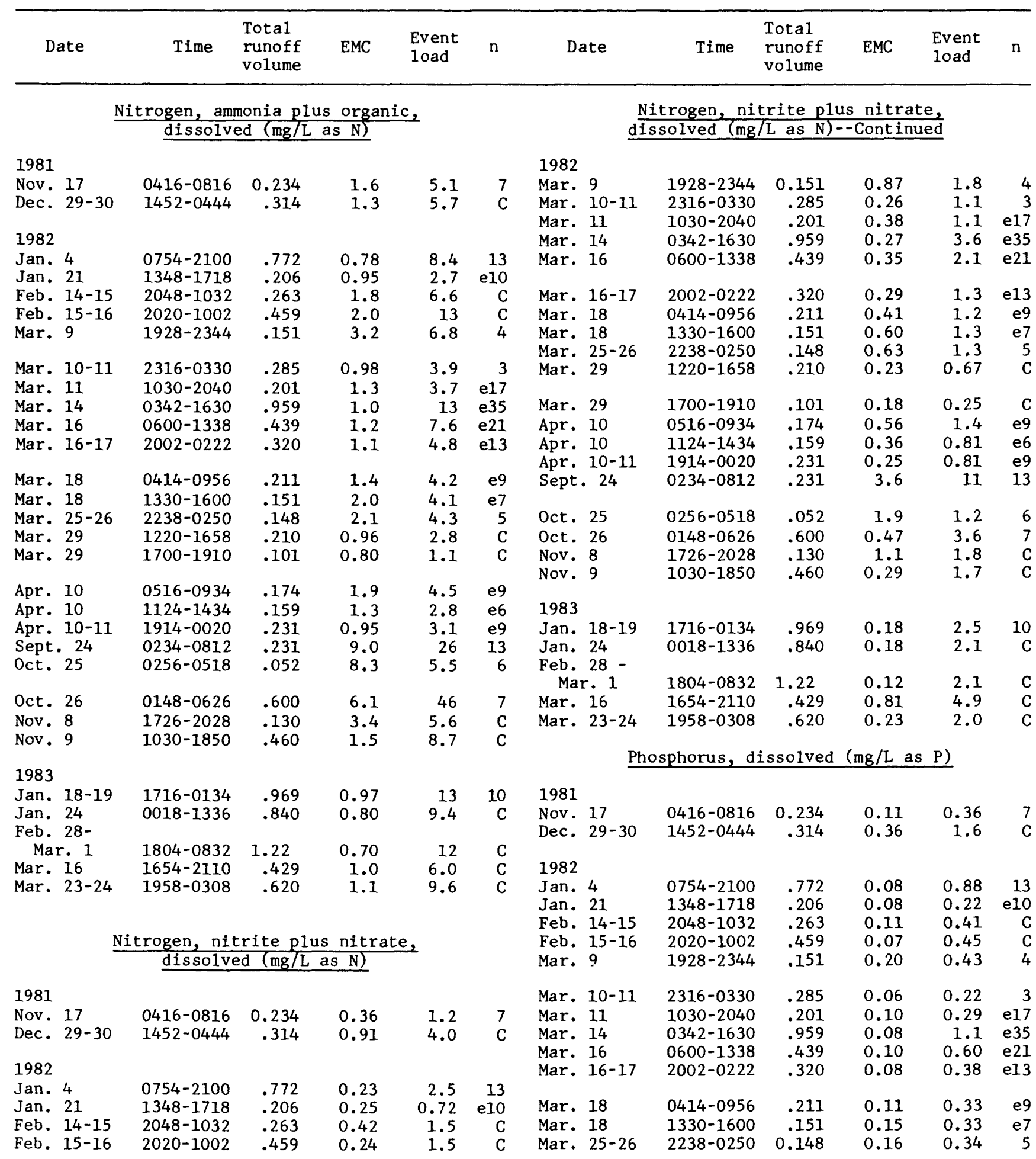


Table 21. Constituent storm-runoff loads: Commercial catchment-Continued

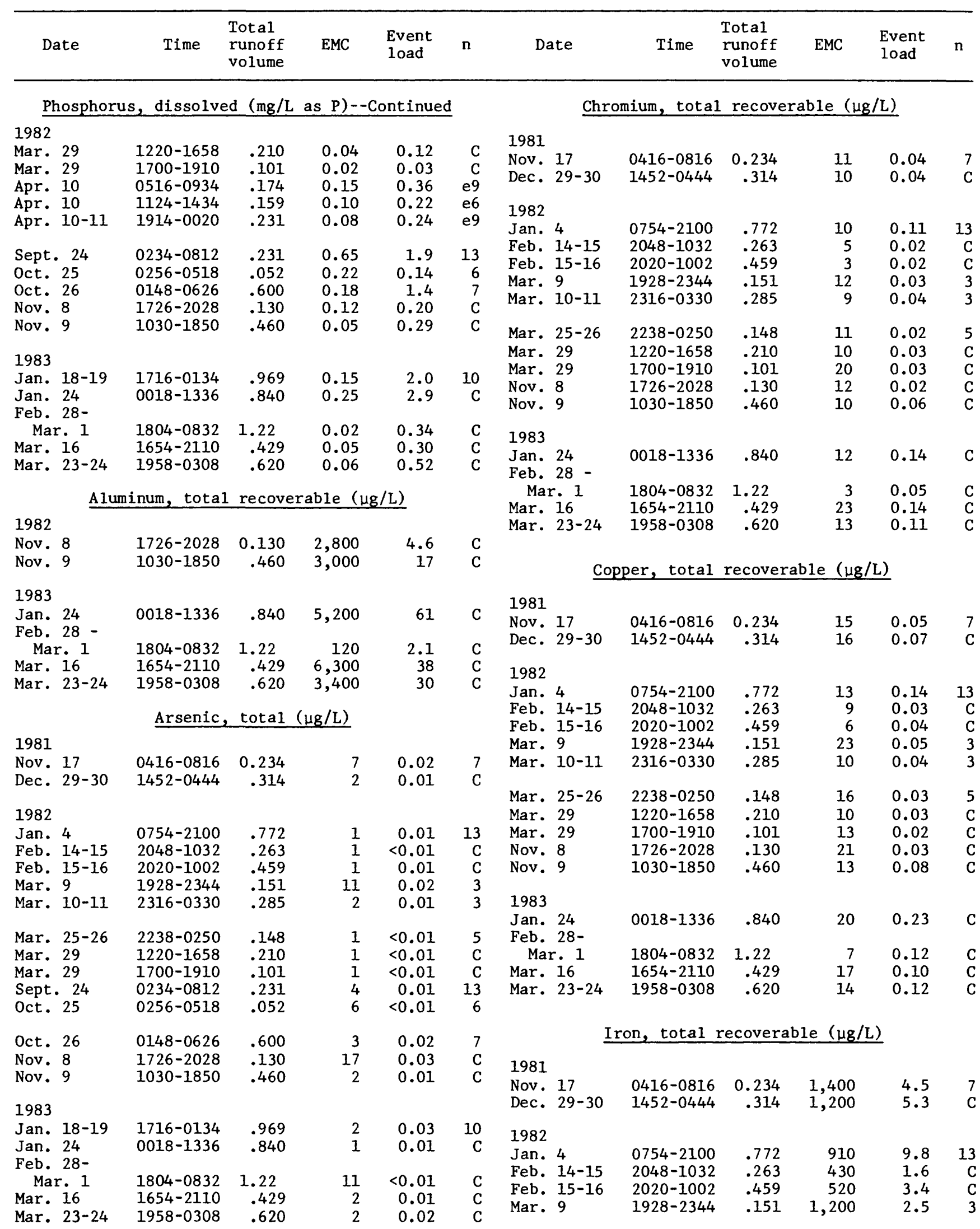


Table 21. Constituent storm-runoff loads: Commercial catchment-Continued

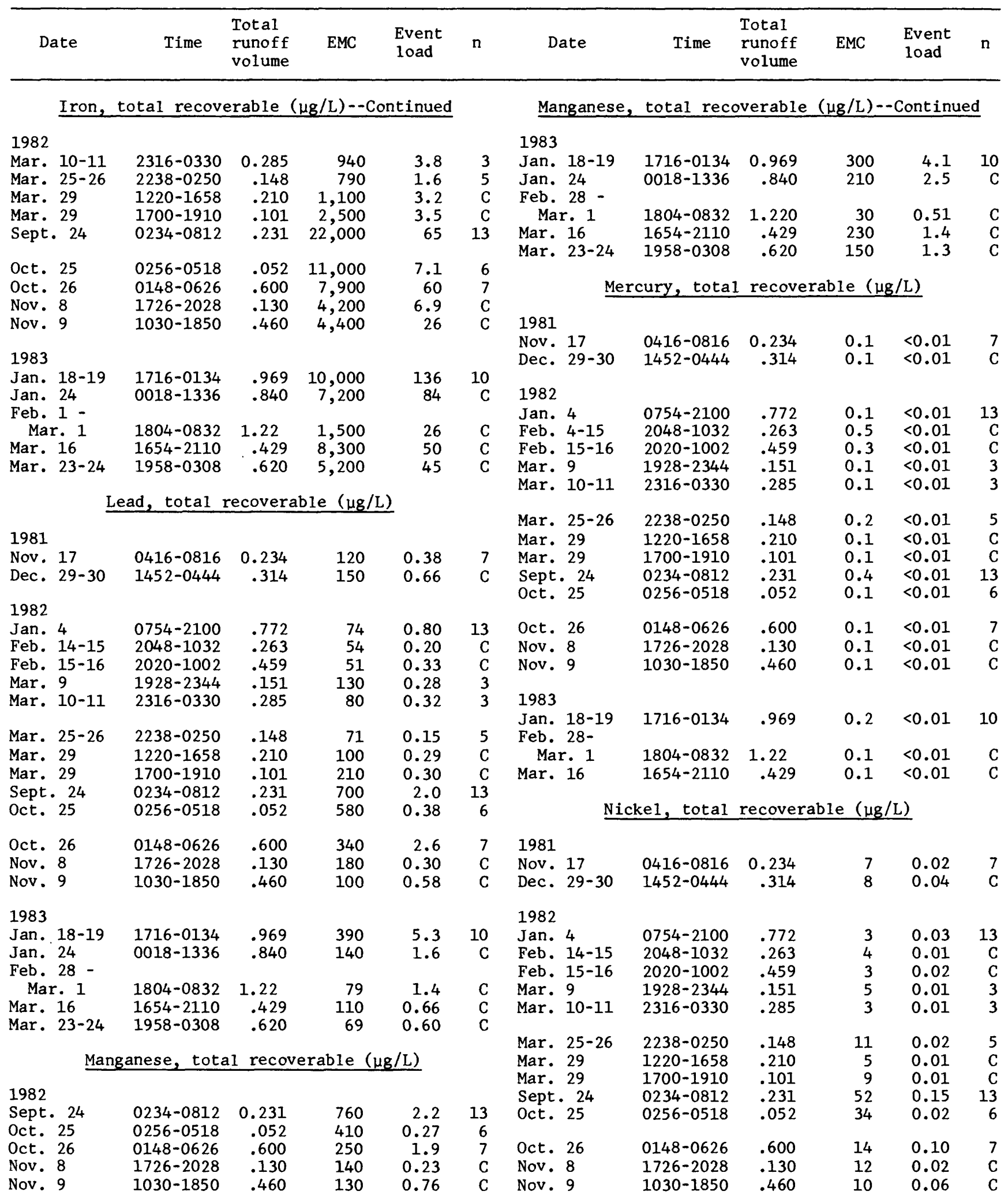


Table 21. Constituent storm-runoff loads: Commercial catchment-Continued

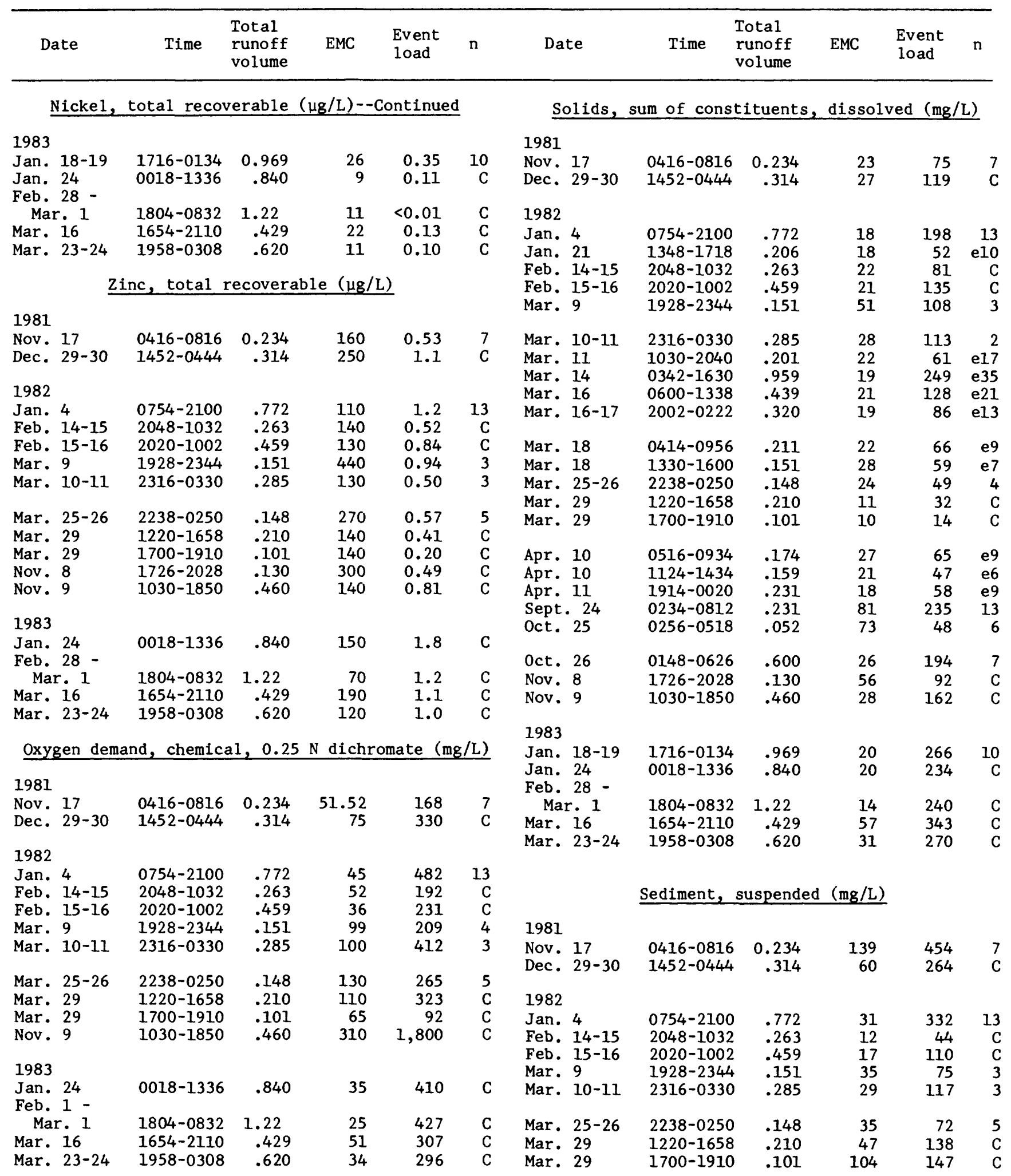


Table 21. Constituent storm-runoff loads: Commercial catchment-Continued

\begin{tabular}{|c|c|c|c|c|c|c|c|c|c|c|c|}
\hline Date & Time & $\begin{array}{l}\text { Total } \\
\text { runoff } \\
\text { volume }\end{array}$ & EMC & $\begin{array}{l}\text { Event } \\
\text { load }\end{array}$ & $\mathrm{n}$ & Date & Time & $\begin{array}{l}\text { Total } \\
\text { runoff } \\
\text { volume }\end{array}$ & EMC & $\begin{array}{l}\text { Event } \\
\text { load }\end{array}$ & $\mathrm{n}$ \\
\hline \multicolumn{6}{|c|}{ Sediment, suspended $(\mathrm{mg} / \mathrm{L})--$ Continued } & \multicolumn{6}{|c|}{ Carbon, organic, dissolved (mg/L)--Continued } \\
\hline $\begin{array}{l}1982 \\
\text { Sept. } 24 \\
\text { Oct. } 25 \\
\text { Oct. } 26 \\
\text { Nov. } 8 \\
\text { Nov. } 9\end{array}$ & $\begin{array}{l}0234-0812 \\
0256-0518 \\
0148-0626 \\
1726-2028 \\
1030-1850\end{array}$ & $\begin{array}{r}0.231 \\
.052 \\
.600 \\
.130 \\
.460\end{array}$ & $\begin{array}{r}1,260 \\
422 \\
586 \\
175 \\
133\end{array}$ & $\begin{array}{r}3,650 \\
279 \\
4,430 \\
287 \\
773\end{array}$ & $\begin{array}{r}13 \\
6 \\
7 \\
C \\
C\end{array}$ & $\begin{array}{l}1983 \\
\text { Jan. } 24 \\
\text { Feb. } 28- \\
\text { Mar. } 1 \\
\text { Mar. 16 } \\
\text { Mar. 23-24 }\end{array}$ & $\begin{array}{l}0018-1336 \\
1804-0832 \\
1654-2110 \\
1958-0308\end{array}$ & $\begin{array}{c}0.840 \\
1.22 \\
.429 \\
.620\end{array}$ & $\begin{array}{l}14 \\
12 \\
14 \\
78\end{array}$ & $\begin{array}{r}164 \\
205 \\
84 \\
679\end{array}$ & $\begin{array}{l}\mathrm{C} \\
\mathrm{C} \\
\mathrm{C}\end{array}$ \\
\hline $\begin{array}{l}1983 \\
\text { Jan. } 18-19 \\
\text { Jan. } 24 \\
\text { Feb. } 28-\end{array}$ & $\begin{array}{l}1716-0134 \\
0018-1336\end{array}$ & $\begin{array}{l}.969 \\
.840\end{array}$ & $\begin{array}{r}1,110 \\
323\end{array}$ & $\begin{array}{r}15,000 \\
3,780\end{array}$ & $\begin{array}{r}10 \\
\mathrm{C}\end{array}$ & \multirow{2}{*}{\multicolumn{5}{|c|}{ Carbon, organic, suspended (mg/L) }} & \\
\hline $\begin{array}{l}\text { Mar. }{ }^{1} \\
\text { Mar. } 16 \\
\text { Mar. } 23-24\end{array}$ & $\begin{array}{l}1804-0832 \\
1654-2110 \\
1958-0308\end{array}$ & $\begin{array}{r}1.22 \\
.429 \\
.620\end{array}$ & $\begin{array}{l}404 \\
291 \\
167\end{array}$ & $\begin{array}{l}6,910 \\
1,750 \\
1,450\end{array}$ & $\begin{array}{l}\mathrm{C} \\
\mathrm{C} \\
\mathrm{C}\end{array}$ & & & & & & $\begin{array}{l}7 \\
\mathrm{C}\end{array}$ \\
\hline $\begin{array}{l}\quad \text { Ca } \\
1981 \\
\text { Nov. } 17 \\
\text { Dec. } 29-30\end{array}$ & $\begin{array}{l}0416-0816 \\
1452-0444\end{array}$ & $\begin{array}{r}0.234 \\
.314\end{array}$ & lved (m & $\begin{array}{r}38 \\
193\end{array}$ & $\begin{array}{l}7 \\
C\end{array}$ & $\begin{array}{l}1982 \\
\text { Jan. } 4 \\
\text { Feb. 14-15 } \\
\text { Feb. } 15-16 \\
\text { Mar. } 9 \\
\text { Mar. 10-11 }\end{array}$ & $\begin{array}{l}0754-2100 \\
2048-1032 \\
2020-1002 \\
1928-2344 \\
2316-0330\end{array}$ & $\begin{array}{l}.772 \\
.263 \\
.459 \\
.151 \\
.285\end{array}$ & $\begin{array}{l}1.4 \\
1.3 \\
2.2 \\
1.9 \\
1.8\end{array}$ & $\begin{array}{r}15 \\
4.7 \\
14 \\
4.1 \\
7.1\end{array}$ & $\begin{array}{r}11 \\
C \\
C \\
4 \\
3\end{array}$ \\
\hline $\begin{array}{l}1982 \\
\text { Jan. } 4 \\
\text { Feb. 14-15 } \\
\text { Feb. 15-16 } \\
\text { Mar. } 9 \\
\text { Mar. 10-11 }\end{array}$ & $\begin{array}{l}0754-2100 \\
2048-1032 \\
2020-1002 \\
1928-2344 \\
2316-0330\end{array}$ & $\begin{array}{l}.772 \\
.263 \\
.459 \\
.151 \\
.285\end{array}$ & $\begin{array}{r}54 \\
26 \\
39 \\
31 \\
170\end{array}$ & $\begin{array}{r}589 \\
96 \\
251 \\
65 \\
695\end{array}$ & $\begin{array}{r}11 \\
C \\
C \\
4 \\
3\end{array}$ & $\begin{array}{l}\text { Mar. } 25-26 \\
\text { Mar. } 29 \\
\text { Mar. } 29 \\
\text { Nov. } 8 \\
\text { Nov. } 9 \\
\text { Feb. } 28-\end{array}$ & $\begin{array}{l}2238-0250 \\
1220-1658 \\
1700-1910 \\
1726-2028 \\
1030-1850\end{array}$ & $\begin{array}{l}.148 \\
.210 \\
.101 \\
.130 \\
.460\end{array}$ & $\begin{array}{l}1.9 \\
2.1 \\
3.2 \\
5.2 \\
3.2\end{array}$ & $\begin{array}{r}3.9 \\
6.2 \\
4.5 \\
8.5 \\
19\end{array}$ & $\begin{array}{l}5 \\
\mathrm{C} \\
\mathrm{C} \\
\mathrm{C} \\
\mathrm{C}\end{array}$ \\
\hline $\begin{array}{l}\text { Mar. } 25-26 \\
\text { Mar. } 29 \\
\text { Mar. } 29 \\
\text { Nov. } 8 \\
\text { Nov. } 9\end{array}$ & $\begin{array}{l}2238-0250 \\
1220-1658 \\
1700-1910 \\
1726-2028 \\
1030-1850\end{array}$ & $\begin{array}{l}.148 \\
.210 \\
.101 \\
.130 \\
.460\end{array}$ & $\begin{array}{r}79 \\
260 \\
49 \\
22 \\
47\end{array}$ & $\begin{array}{r}164 \\
764 \\
69 \\
36 \\
272\end{array}$ & $\begin{array}{l}5 \\
C \\
C \\
C \\
C\end{array}$ & $\begin{array}{c}\text { Mar. } 1 \\
\text { Mar. } 23-24\end{array}$ & $\begin{array}{l}1804-0832 \\
1958-0308\end{array}$ & $\begin{array}{r}1.22 \\
.620\end{array}$ & $\begin{array}{l}2.9 \\
3.3\end{array}$ & $\begin{array}{l}50 \\
29\end{array}$ & $\begin{array}{l}\mathrm{C} \\
\mathrm{C}\end{array}$ \\
\hline
\end{tabular}


Table 22. Significant variables affecting constituent event mean concentrations

[RUNOFF, runoff volume; DRYHRS, number of dry hours since last storm; SFIRST, number of days since first storm of rain season. ., none of the three variables were significant]

\begin{tabular}{|c|c|c|c|c|}
\hline \multirow[b]{2}{*}{ Constituent } & \multicolumn{4}{|c|}{ Catchment } \\
\hline & Industrial & $\begin{array}{c}\text { Single- } \\
\text { dwelling } \\
\text { residential }\end{array}$ & $\begin{array}{l}\text { Multiple- } \\
\text { dwelling } \\
\text { residential }\end{array}$ & Commercial \\
\hline \multicolumn{5}{|l|}{ Nutrients } \\
\hline $\begin{array}{l}\text { Nitrogen, ammonia plus } \\
\text { organic, dissolved-- }\end{array}$ & $\begin{array}{l}\text { RUNOFF, } \\
\text { SFIRST }\end{array}$ & RUNOFF & $\begin{array}{l}\text { DRYHRS, } \\
\text { RUNOFF }\end{array}$ & $\begin{array}{l}\text { DRYHRS, } \\
\text { SFIRST }\end{array}$ \\
\hline $\begin{array}{l}\text { Nitrogen, nitrite plus } \\
\text { nitrate, dissolved-- }\end{array}$ & DRYHRS & RUNOFF & $\begin{array}{l}\text { DRYHRS, } \\
\text { RUNOFF, } \\
\text { SFIRST }\end{array}$ & $\begin{array}{l}\text { DRYHRS, } \\
\text { RUNOFF }\end{array}$ \\
\hline Phosphorus, dissolved-------- & RUNOFF & $\begin{array}{l}\text { RUNOFF, } \\
\text { DRYHRS, } \\
\text { SFIRST }\end{array}$ & $\begin{array}{l}\text { DRYHRS, } \\
\text { RUNOFF }\end{array}$ & . \\
\hline \multicolumn{5}{|l|}{ Oxygen demand } \\
\hline Oxygen demand, chemical------ & $\begin{array}{l}\text { RUNOFF, } \\
\text { SFIRST }\end{array}$ & DRYHRS & $\begin{array}{l}\text { DRYHRS, } \\
\text { RUNOFF }\end{array}$ & - \\
\hline \multicolumn{5}{|l|}{ Organics } \\
\hline Carbon, organic, dissolved--- & • & . & - & . \\
\hline Carbon, organic, suspended--- & SFIRST & DRYHRS, & $\dot{\text { SFIRST }}$ & . \\
\hline \multicolumn{5}{|l|}{ Metals } \\
\hline$\overline{\text { Arsenic }}$, total-_- & - & - & - & - \\
\hline Chromium, total recoverable-- & . & - & $\begin{array}{l}\text { DRYHRS, } \\
\text { RUNOFF, } \\
\text { SFIRST }\end{array}$ & - \\
\hline Copper, total recoverable---- & . & SFIRST & - & DRYHRS \\
\hline Iron, total recoverable------ & - & - & SFIRST & . \\
\hline Lead, total recoverable----- & $\dot{0}$ & SFIRST & SFIRST & - \\
\hline Mercury, total recoverable--- & DRYHRS & - & SFIRST & . \\
\hline Nickel, total recoverable---- & - & $\cdot$ & - & - \\
\hline Zinc, total recoverable------ & . & SFIRST & - & DRYHRS \\
\hline \multicolumn{5}{|l|}{ Physical properties } \\
\hline $\begin{array}{l}\text { Solids, sum of constituents, } \\
\text { dissolved-- }\end{array}$ & $\cdot$ & - & $\begin{array}{l}\text { DRYHRS, } \\
\text { RUNOFF }\end{array}$ & DRYHRS \\
\hline Sediment, suspended-------- & - & SFIRST & SFIRST & RUNOFF \\
\hline
\end{tabular}


Table 23. Results of linear regression analysis using runoff event mean concentration data

[Form of equation: $a$, regression constant; $b, c, d$, regression coefficient; $x_{1}, x_{2}, x_{3}$, independent variable]

\begin{tabular}{|c|c|c|c|c|c|c|c|c|c|c|}
\hline \multirow{2}{*}{ Dependent variable } & \multicolumn{7}{|c|}{ Form of equation: $y=a+b x_{1}+c x_{2}+d x_{3}$} & \multirow{2}{*}{$\begin{array}{l}\text { Adjusted } \\
\text { percent- } \\
\text { age of } \\
\text { variation } \\
\text { explained } \\
\quad\left(R^{2}\right)\end{array}$} & \multirow{2}{*}{$\begin{array}{l}\text { Root } \\
\text { mean } \\
\text { square } \\
\text { error }\end{array}$} & \multirow{2}{*}{$\begin{array}{l}\text { Number } \\
\text { of data } \\
\text { observa- } \\
\text { tions }\end{array}$} \\
\hline & a & $b$ & $x_{1}$ & c & $x_{2}$ & $d$ & $x_{3}$ & & & \\
\hline \multicolumn{11}{|c|}{ Industrial catchment } \\
\hline $\begin{array}{l}\text { Nitrogen, ammonia plus } \\
\text { organic, dissolved } \\
\text { Nitrogen, nitrite plus }\end{array}$ & 24.0 & -48.3 & RUNOFF & -0.062 & SFIRST & . & . & 59 & 3.88 & 12 \\
\hline nitrate, dissolved & 0.4 & -0.00258 & DRYHRS & . & . & - & . & 32 & 0.241 & 12 \\
\hline $\begin{array}{l}\text { Phosphorus, dissolved } \\
\text { 0xygen demand, }\end{array}$ & 6.31 & -15.7 & RUNOFF & . & . & . & $\dot{.}$ & 34 & 1.71 & 12 \\
\hline $\begin{array}{l}\text { chemical } \\
\text { Carbon, organic, }\end{array}$ & 943 & -1290 & RUNOFF & -3.55 & SFIRST & . & . & 77 & 93.8 & 10 \\
\hline $\begin{array}{l}\text { suspended } \\
\text { Mercury, total }\end{array}$ & 37.1 & -0.110 & SFIRST & - & . & . & - & 26 & 7.95 & 11 \\
\hline recoverable & 0.122 & 0.0000962 & DRYHRS & - & . & . & . & 27 & 0.040 & 12 \\
\hline \multicolumn{11}{|c|}{ Single-dwelling residential catchment } \\
\hline $\begin{array}{l}\text { Nitrogen, ammonia plus } \\
\text { organic, dissolved } \\
\text { Nitrogen, nitrite plus }\end{array}$ & 2.96 & -7.98 & RUNOFF & . & . & . & . & 36 & 0.836 & 17 \\
\hline nitrate, dissolved & 0.619 & -1.78 & RUNOFF & . & & & . & 39 & 0.177 & 17 \\
\hline $\begin{array}{l}\text { Phosphorus, dissolved } \\
\text { Oxygen demand, }\end{array}$ & 0.307 & 0.000526 & RUNOFF & -0.532 & DRYHRS & -0.000619 & SFIRST & 69 & 0.044 & 17 \\
\hline $\begin{array}{l}\text { chemical } \\
\text { Carbon, organic, }\end{array}$ & 29.3 & 0.615 & DRYHRS & . & . & . & . & 68 & 19.6 & 9 \\
\hline $\begin{array}{l}\text { suspended } \\
\text { Copper, total }\end{array}$ & 9.76 & -0.016 & DRYHRS & -0.040 & SFIRST & - & - & 69 & 1.44 & 8 \\
\hline $\begin{array}{l}\text { recoverable } \\
\text { Lead, total }\end{array}$ & 25.2 & -0.098 & SFIRST & . & . & . & . & 86 & 2.11 & 7 \\
\hline $\begin{array}{l}\text { recoverable } \\
\text { Zinc, total }\end{array}$ & 357 & -1.77 & SFIRST & . & . & . & - & 88 & 37.5 & 9 \\
\hline recoverable & 170 & -0.585 & SFIRST & . & . & . & . & 63 & 23.3 & 7 \\
\hline Sediment, suspended & 321 & -1.80 & SFIRST & . & . & ${ }^{\circ}$ & . & 71 & 66.7 & 10 \\
\hline \multicolumn{11}{|c|}{ Multiple-dwelling residential catchment } \\
\hline $\begin{array}{l}\text { Nitrogen, ammonia plus } \\
\text { organic, dissolved } \\
\text { Nitrogen, nitrite plus }\end{array}$ & 1.41 & -1.44 & RUNOFF & . & DRYHRS & . & . & 49 & 0.515 & 31 \\
\hline nitrate, dissolved & 0.213 & -0.308 & RUNOFF & 0.000573 & DRYHRS & 0.00119 & SFIRST & 33 & 0.140 & 30 \\
\hline $\begin{array}{l}\text { Phosphorus, dissolved } \\
\text { oxygen demand, }\end{array}$ & 0.190 & -0.127 & RUNOFF & 0.000443 & DRYHRS & . & . & 51 & 0.057 & 32 \\
\hline $\begin{array}{l}\text { chemical } \\
\text { Solids, sum of }\end{array}$ & 80.5 & -51.3 & RUNOFF & 0.100 & DRYHRS & . & . & 57 & 16.6 & 16 \\
\hline $\begin{array}{l}\text { constituents, dissolved } \\
\text { Chromium, total }\end{array}$ & 29.4 & -14.2 & RUNOFF & 0.0235 & DRYHRS & & & 39 & 5.21 & 31 \\
\hline $\begin{array}{l}\text { recoverable } \\
\text { Iron, total }\end{array}$ & 29.8 & -9.76 & RUNOFF & -0.017 & DRYHRS & -0.094 & SFIRST & 64 & 3.91 & 18 \\
\hline $\begin{array}{l}\text { recoverable } \\
\text { Lead, total }\end{array}$ & 11300 & -46.5 & SFIRST & . & - & - & . & 34 & 2750 & 17 \\
\hline $\begin{array}{l}\text { recoverable } \\
\text { Mercury, total }\end{array}$ & 247 & -0.767 & SFIRST & . & . & - & . & 18 & 69.5 & 18 \\
\hline $\begin{array}{l}\text { recoverable } \\
\text { Sediment, suspended }\end{array}$ & $\begin{array}{r}0.307 \\
788\end{array}$ & $\begin{array}{r}-0.000991 \\
-4.00\end{array}$ & $\begin{array}{l}\text { SFIRST } \\
\text { SFIRST }\end{array}$ & $\dot{.}$ & $\dot{.}$ & $\dot{.}$ & $\dot{.}$ & $\begin{array}{l}29 \\
52\end{array}$ & $\begin{array}{r}0.071 \\
182\end{array}$ & $\begin{array}{l}15 \\
12\end{array}$ \\
\hline \multicolumn{11}{|c|}{ Commercial catchment } \\
\hline $\begin{array}{l}\text { Nitrogen, ammonia plus } \\
\text { organic, dissolved } \\
\text { Nitrogen, nitrite plus }\end{array}$ & 2.60 & 0.00570 & DRYHRS & -0.011 & SFIRST & . & . & 28 & 0.939 & 28 \\
\hline $\begin{array}{l}\text { nitrate, dissolved } \\
\text { Solids, sum of }\end{array}$ & 0.4 & -0.00213 & DRYHRS & -0.267 & RUNOFF & . & . & 47 & 0.183 & 28 \\
\hline $\begin{array}{l}\text { constituents, dissolved } \\
\text { Copper, total }\end{array}$ & 20.2 & 0.104 & DRYHRS & . & . & - & . & 34 & 9.45 & 28 \\
\hline $\begin{array}{l}\text { recoverable } \\
\text { Zinc, total }\end{array}$ & 11.4 & 0.046 & DRYHRS & . & . & . & . & 43 & 3.70 & 16 \\
\hline recoverable & 124 & 1.04 & DRYHRS & . & . & . & . & 64 & 56.4 & 16 \\
\hline Sediment, suspended & 22.3 & 305 & RUNOFF & . & . & . & . & 29 & 137 & 17 \\
\hline
\end{tabular}


Table 24. Statistical summary of runoff event mean concentration data for all monitored catchments

[Computation maximum and minimum are the maximum and minimum event mean concentrations (EMC) of data set used to compute mean after excluding early rain season high event mean concentration. Study maximum equals maximum event mean concentration for study period. ., no data available]

\begin{tabular}{|c|c|c|c|c|c|c|}
\hline \multirow{2}{*}{ Catchment } & \multirow{2}{*}{ Mean } & \multirow{2}{*}{$\begin{array}{l}\text { Standard } \\
\text { error }\end{array}$} & \multirow{2}{*}{$\begin{array}{l}\text { Number } \\
\text { of EMC } \\
\text { values }\end{array}$} & \multicolumn{2}{|c|}{ Computation } & \multirow{2}{*}{$\begin{array}{l}\text { Study } \\
\text { maximum }\end{array}$} \\
\hline & & & & Maximum & Minimum & \\
\hline \multicolumn{7}{|c|}{ Nitrogen, ammonia plus organic, dissolved (mg/L as $N$ ) } \\
\hline Industrial & 13 & 1.8 & 12 & 22 & 3.6 & 28 \\
\hline $\begin{array}{l}\text { Single-dwelling } \\
\text { residential }\end{array}$ & 2.0 & 0.25 & 17 & 4.8 & 0.68 & 12 \\
\hline $\begin{array}{l}\text { Multiple-dwelling } \\
\text { residential }\end{array}$ & 1.4 & 0.13 & 31 & 3.2 & 0.20 & 7.4 \\
\hline Commercial & 1.6 & 0.21 & 28 & 3.4 & 0.70 & 9.0 \\
\hline \multicolumn{7}{|c|}{ Nitrogen, nitrite plus nitrate, dissolved (mg/L as $N$ ) } \\
\hline $\begin{array}{l}\text { Industrial } \\
\text { Single-dwelling }\end{array}$ & 0.63 & 0.08 & 12 & 1.1 & 0.28 & 3.9 \\
\hline $\begin{array}{l}\text { residential } \\
\text { Multiple-dwelling }\end{array}$ & 0.40 & 0.06 & 17 & 0.97 & 0.14 & 3.2 \\
\hline residential & 0.33 & 0.03 & 30 & 0.83 & 0.13 & 2.2 \\
\hline Commercial & 0.41 & 0.05 & 28 & 1.1 & 0.12 & 3.6 \\
\hline \multicolumn{7}{|c|}{ Phosphorus, dissolved (mg/L as P) } \\
\hline $\begin{array}{l}\text { Industrial } \\
\text { Single-dwelling }\end{array}$ & 4.8 & 0.48 & 15 & 7.8 & 2.0 & 7.8 \\
\hline $\begin{array}{l}\text { residential } \\
\text { Multiple-dwelling }\end{array}$ & 0.20 & 0.02 & 17 & 0.38 & 0.09 & 0.99 \\
\hline residential & 0.20 & 0.01 & 32 & 0.43 & 0.06 & 0.82 \\
\hline Commercial & 0.11 & 0.01 & 28 & 0.36 & 0.02 & 0.65 \\
\hline \multicolumn{7}{|c|}{ Aluminum, total recoverable $(\mu \mathrm{g} / \mathrm{L})$} \\
\hline Industrial & 6,500 & 330 & 3 & 7,100 & 6,000 & 7,100 \\
\hline $\begin{array}{l}\text { Single-dwelling } \\
\text { residential } \\
\text { Multiple-dwelling }\end{array}$ & 1,700 & 540 & 5 & 3,400 & 560 & 3,400 \\
\hline residential & 2,900 & 450 & 5 & 4,400 & 1,600 & 4,400 \\
\hline Commercial & - & - & 0 & - & - & - \\
\hline \multicolumn{7}{|c|}{ Arsenic, total $(\mu \mathrm{g} / \mathrm{L})$} \\
\hline $\begin{array}{l}\text { Industrial } \\
\text { Single-dwelling }\end{array}$ & 18 & 2 & 17 & 30 & 8 & 30 \\
\hline $\begin{array}{l}\text { residential } \\
\text { Multiple-dwelling }\end{array}$ & 1 & 0 & 8 & 2 & 1 & 4 \\
\hline residential & 2 & 0 & 13 & 2 & 1 & 8 \\
\hline Commercial & 2 & 0 & 15 & 7 & 1 & 17 \\
\hline \multicolumn{7}{|c|}{ Chromium, total recoverable $(\mu \mathrm{g} / \mathrm{L})$} \\
\hline $\begin{array}{l}\text { Industrial } \\
\text { Single-dwelling }\end{array}$ & 21 & 4 & 14 & 51 & 8 & 51 \\
\hline $\begin{array}{l}\text { residential } \\
\text { Multiple-dwelling }\end{array}$ & 7 & 2 & 8 & 13 & 1 & 13 \\
\hline residential & 15 & 2 & 18 & 28 & 6 & 28 \\
\hline Commercial & 11 & 1 & 16 & 23 & 3 & 23 \\
\hline
\end{tabular}


Table 24. Statistical summary of runoff event mean concentration data for all monitored catchmentsContinued

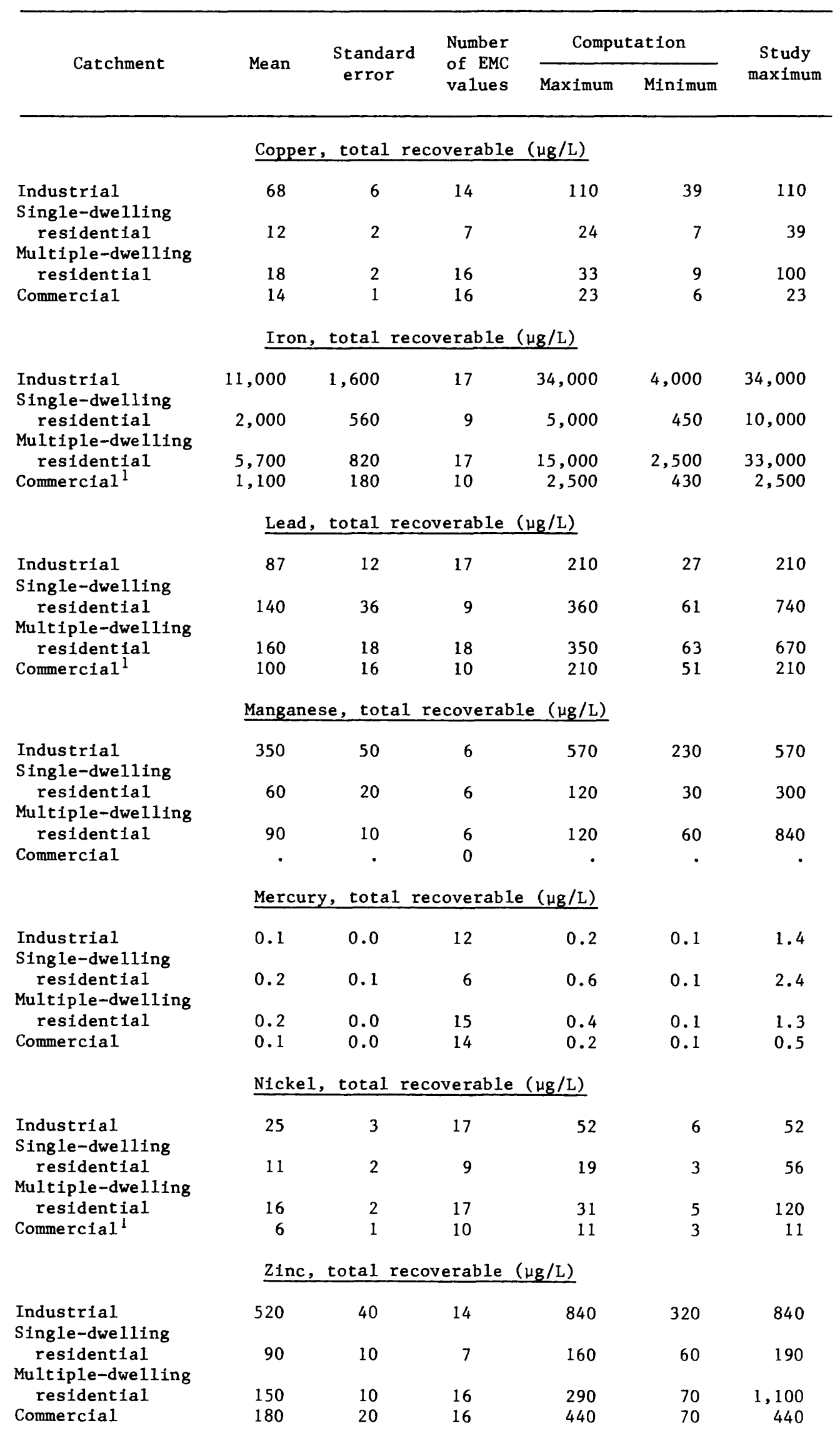


Table 24. Statistical summary of runoff event mean concentration data for all monitored catchmentsContinued

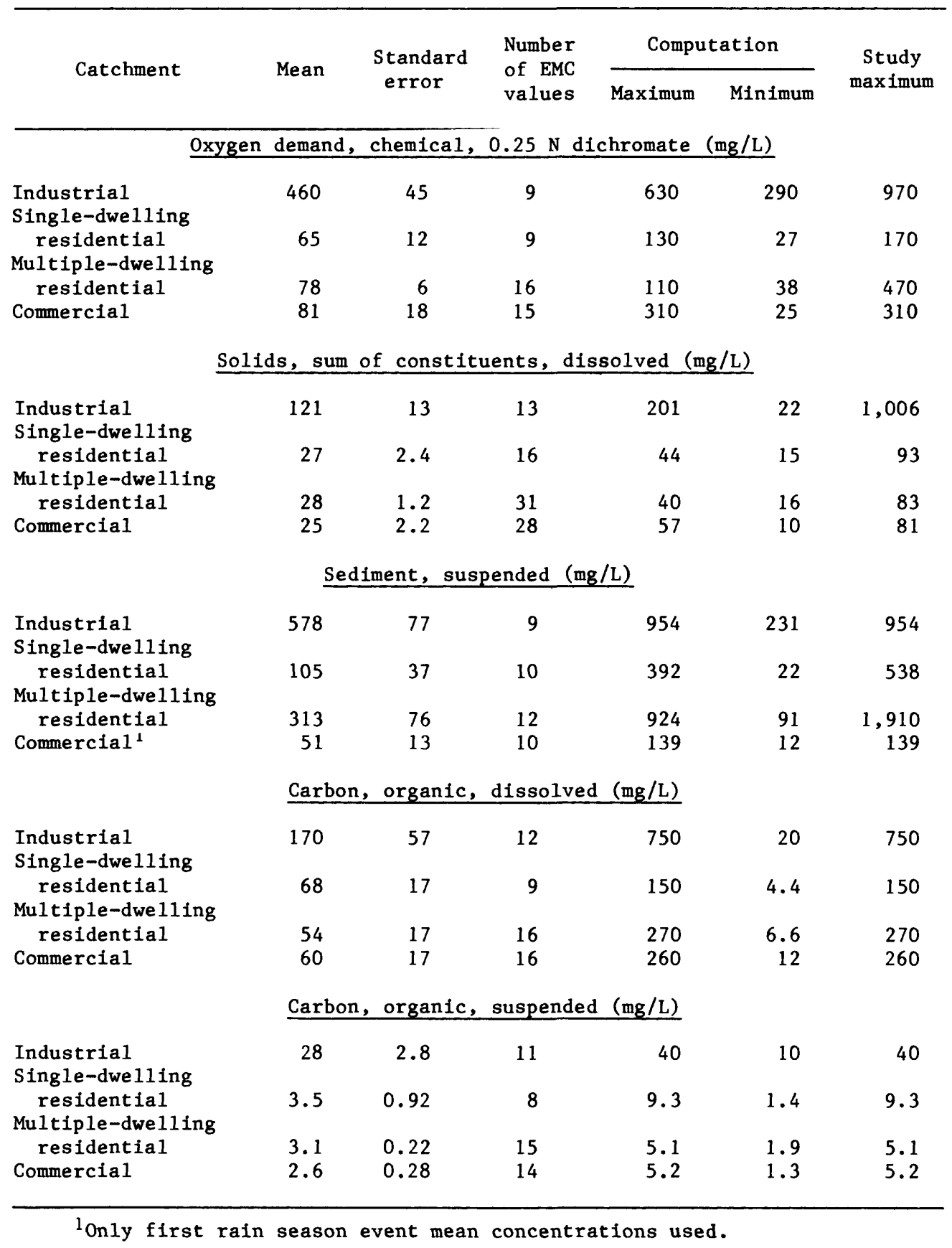


Table 25. Estimated average annual constituent unit loads for each land-use type

\begin{tabular}{|c|c|c|c|c|}
\hline & \multicolumn{4}{|c|}{ Catchment } \\
\hline & Industrial & $\begin{array}{c}\text { Single- } \\
\text { dwelling } \\
\text { residential }\end{array}$ & $\begin{array}{l}\text { Multiple- } \\
\text { dwelling } \\
\text { residential }\end{array}$ & Commercial \\
\hline \multicolumn{5}{|l|}{ Mean rainfall-runoff } \\
\hline coefficient* & 0.18 & 0.21 & 0.39 & 0.93 \\
\hline \multicolumn{5}{|l|}{ Mean annual catchment } \\
\hline runoff, in inches** & 1.84 & 2.15 & 3.99 & 9.52 \\
\hline Constituent & \multicolumn{4}{|c|}{$\begin{array}{l}\text { Mean annual constituent unit load } \\
\text { (pounds per acre) }\end{array}$} \\
\hline \multicolumn{5}{|l|}{ Nitrogen, organic plus } \\
\hline \multicolumn{5}{|l|}{ Nitrogen, nitrite plus } \\
\hline nitrate, dissolved & 0.26 & 0.19 & 0.30 & 0.88 \\
\hline Phosphorus, dissolved & 2.0 & 0.10 & 0.18 & 0.24 \\
\hline Oxygen demand, chemical & 190 & 32 & 70 & 180 \\
\hline Carbon, organic, dissolved & 77 & 33 & 49 & 130 \\
\hline Carbon, organic, suspended & 11 & 1.7 & 2.8 & 5.6 \\
\hline Aluminum, total recoverable & 2.7 & 0.81 & 2.7 & $\cdot$ \\
\hline Arsenic, total & 0.0074 & 0.0005 & 0.0014 & 0.0040 \\
\hline Chromium, total recoverable & 0.0088 & 0.0036 & 0.014 & 0.024 \\
\hline Copper, total recoverable & 0.028 & 0.0057 & 0.016 & 0.030 \\
\hline Iron, total recoverable & 4.5 & 1.0 & 5.2 & 2.4 \\
\hline Lead, total recoverable & 0.036 & 0.068 & 0.14 & 0.22 \\
\hline Manganese, total recoverable & 0.15 & 0.029 & 0.084 & \\
\hline Mercury, total recoverable & 0.0001 & 0.0001 & 0.0002 & 0.0002 \\
\hline Nicke1, total recoverable & 0.010 & 0.0054 & 0.014 & 0.013 \\
\hline Zinc, total recoverable & 0.21 & 0.044 & 0.14 & 0.39 \\
\hline \multicolumn{5}{|l|}{ Solids, sum of constituents, } \\
\hline dissolved & 50 & 13 & 25 & 54 \\
\hline Sediment, suspended & 240 & 51 & 283 & 110 \\
\hline
\end{tabular}

*Taken from table 5 .

**Based on average annual rainfall of 10.24 inches. 
Table 26. Statistical summary of atmospheric dry-deposition quality data: Industrial site

[Statistical calculations include analytical detection limit concentration for those analyses that are reported to be less than detection limit. Mass concentrations determined by dividing bucket-washed sample constituent concentration by total solids concentration and muliplying by $10^{6}$. $<$, actual value is less than value shown. ., not calculated]

\begin{tabular}{|c|c|c|c|c|c|}
\hline $\begin{array}{l}\text { Property or } \\
\text { constituent }\end{array}$ & $\begin{array}{l}\text { Number } \\
\text { of } \\
\text { samples }\end{array}$ & Mean & $\begin{array}{l}\text { Standard } \\
\text { deviation }\end{array}$ & Maximum & Minimum \\
\hline \multicolumn{6}{|l|}{$\begin{array}{l}\text { INORGANICS } \\
\text { Major ions }(\mathrm{mg} / \mathrm{kg})\end{array}$} \\
\hline $\begin{array}{l}\text { Calcium, dissolved } \\
\text { Magnesium, dissolved } \\
\text { Sodium, dissolved } \\
\text { Potassium, dissolved } \\
\text { Sulfate, dissolved } \\
\text { Chloride, dissolved } \\
\text { Silica, dissolved }\end{array}$ & $\begin{array}{r}10 \\
10 \\
10 \\
10 \\
10 \\
10 \\
5\end{array}$ & $\begin{array}{r}12,400 \\
5,950 \\
9,070 \\
18,500 \\
63,800 \\
9,360 \\
3,000\end{array}$ & $\begin{array}{r}9,040 \\
5,760 \\
6,950 \\
20,700 \\
58,000 \\
7,340 \\
2,540\end{array}$ & $\begin{array}{r}31,100 \\
2,100 \\
21,000 \\
74,200 \\
178,000 \\
25,800 \\
7,320\end{array}$ & $\begin{array}{r}2,760 \\
780 \\
1,380 \\
2,760 \\
<922 \\
2,300 \\
1,050\end{array}$ \\
\hline \multicolumn{6}{|l|}{ Nutrients (mg/kg) } \\
\hline $\begin{array}{l}\text { dissolved (as } N \text { ) } \\
\text { Nitrogen, ammonia, total (as } N \text { ) } \\
\text { Nitrogen, ammonia plus organic, }\end{array}$ & $\begin{array}{l}10 \\
10\end{array}$ & $\begin{array}{r}9,330 \\
12,000\end{array}$ & $\begin{array}{l}12,400 \\
13,900\end{array}$ & $\begin{array}{l}42,200 \\
46,800\end{array}$ & $\begin{array}{l}1,200 \\
1,050\end{array}$ \\
\hline $\begin{array}{l}\text { total (as N) } \\
\text { Nitrogen, organic, total (as N) } \\
\text { Phosphorus, total (as P) } \\
\text { Phosphorus, orthophosphate, }\end{array}$ & $\begin{array}{r}10 \\
9 \\
10\end{array}$ & $\begin{array}{r}62,200 \\
52,100 \\
5,160\end{array}$ & $\begin{array}{r}43,200 \\
40,400 \\
2,990\end{array}$ & $\begin{array}{r}136,000 \\
129,000 \\
10,600\end{array}$ & $\begin{array}{r}13,400 \\
12,400 \\
1,290\end{array}$ \\
\hline total (as P) & 10 & 4,490 & 7,620 & 25,800 & 553 \\
\hline \multicolumn{6}{|l|}{ Metals $(\mu g / k g)$} \\
\hline $\begin{array}{l}\text { Aluminum, total recoverable } \\
\text { Aluminum, dissolved } \\
\text { Arsenic, total } \\
\text { Chromium, total recoverable } \\
\text { Copper, total recoverable } \\
\text { Copper, dissolved } \\
\text { Iron, total recoverable } \\
\text { Iron, dissolved } \\
\text { Lead, total recoverable } \\
\text { Lead, dissolved } \\
\text { Manganese, total recoverable } \\
\text { Manganese, dissolved } \\
\text { Mercury, total recoverable } \\
\text { Nickel, total recoverable } \\
\text { Nickel, dissolved } \\
\text { Zinc, total recoverable } \\
\text { Zinc, dissolved- }\end{array}$ & $\begin{array}{r}5 \\
2 \\
5 \\
5 \\
5 \\
2 \\
5 \\
2 \\
10 \\
7 \\
5 \\
2 \\
5 \\
5 \\
2 \\
5 \\
2\end{array}$ & $\begin{array}{r}18,400,000 \\
451,000 \\
14,400 \\
155,500 \\
415,000 \\
183,000 \\
25,000,000 \\
330,000 \\
627,000 \\
36,300 \\
754,000 \\
282,000 \\
2,140 \\
134,000 \\
25,800 \\
1,630,000 \\
534,000\end{array}$ & $\begin{array}{r}12,400,000 \\
305,000 \\
8,490 \\
97,100 \\
205,000 \\
150,000 \\
15,900,000 \\
67,900 \\
434,000 \\
42,200 \\
512,000 \\
9,190 \\
1,530 \\
115,000 \\
5,090 \\
775,000 \\
189,000\end{array}$ & $\begin{array}{r}33,300,000 \\
667,000 \\
23,500 \\
289,000 \\
689,000 \\
289,000 \\
42,400,000 \\
378,000 \\
1,610,000 \\
97,600 \\
1,330,000 \\
289,000 \\
4,440 \\
329,000 \\
29,400 \\
2,440,000 \\
667,000\end{array}$ & $\begin{array}{r}8,290,000 \\
235,000 \\
4,610 \\
27,600 \\
115,000 \\
76,500 \\
11,100,000 \\
282,000 \\
140,000 \\
<3,380 \\
276,000 \\
276,000 \\
741 \\
27,600 \\
<22,200 \\
369,000 \\
400,000\end{array}$ \\
\hline \multicolumn{6}{|l|}{ PHYSICAL PROPERTIES } \\
\hline $\begin{array}{l}\text { total, (mg/L) } \\
\text { Solids, sum of constituents, }\end{array}$ & 10 & 211 & 243 & 856 & 41 \\
\hline dissolved $(\mathrm{mg} / \mathrm{kg})-(10)$ & 4 & 226,000 & 203,000 & 452,000 & 44,400 \\
\hline \multicolumn{6}{|l|}{ ORGANICS } \\
\hline $\begin{array}{l}\text { Carbon, organic, dissolved } \\
\quad(\mathrm{mg} / \mathrm{kg} \text { as } \mathrm{C})\end{array}$ & 10 & 118,000 & 123,000 & 390,000 & 10,100 \\
\hline \multicolumn{6}{|l|}{ Pesticides $(\mu \mathrm{g} / \mathrm{kg})$} \\
\hline $\begin{array}{l}\text { Chlordane, total recoverable } \\
\text { DDE, total recoverable } \\
\text { Diazinon, total recoverable } \\
\text { Lindane, total recoverable } \\
\text { Malathion, total recoverable }\end{array}$ & $\begin{array}{l}1 \\
1 \\
1 \\
1 \\
1\end{array}$ & $\begin{array}{r}270 \\
13 \\
120 \\
13 \\
200\end{array}$ & $\dot{:}$ & $\begin{array}{r}270 \\
13 \\
120 \\
13 \\
200\end{array}$ & $\begin{array}{r}270 \\
13 \\
120 \\
13 \\
200\end{array}$ \\
\hline
\end{tabular}


Table 26. Statistical summary of atmospheric dry-deposition quality data: Industrial site-Continued

Other pesticides analyzed but not detected (one sample)

\begin{tabular}{|c|c|c|c|}
\hline $\begin{array}{l}\text { Pesticide } \\
\text { (total recoverable) }\end{array}$ & $\begin{array}{l}\text { *Detection } \\
\text { limit } \\
(\mu \mathrm{g} / \mathrm{L})\end{array}$ & $\begin{array}{cc}\text { Pesticide } & \text { *Detection } \\
\text { (total recoverable }) & 1 \text { imit } \\
(\mu g / L)\end{array}$ & $\begin{array}{cc}\text { Pesticide } & \text { *Detection } \\
\text { (total recoverable) } & \text { limit } \\
& (\mu \mathrm{g} / \mathrm{L})\end{array}$ \\
\hline $\begin{array}{l}\text { Aldrin } \\
\text { DDDT } \\
\text { Dieldrin- } \\
\text { Endosulfan } \\
\text { Endrinn } \\
\text { Ethion } \\
\text { Gross polychlorinated } \\
\quad \text { biphenyls }\end{array}$ & 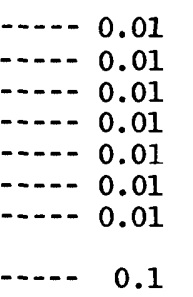 & 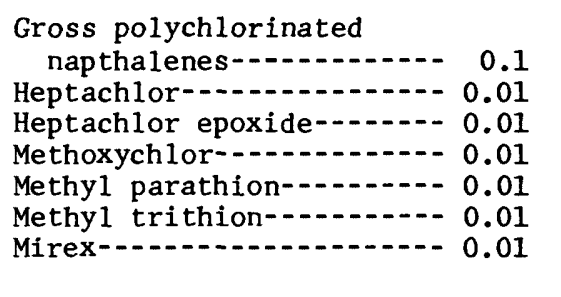 & $\begin{array}{l}\text { Parathion- } \\
\text { Perthane- } \\
\text { Silvex } \\
\text { Toxaphene- } \\
\text { Trithion- } \\
2,4-\mathrm{D}-01 \\
2,4-\mathrm{DP} \\
2,4,5-\mathrm{T}\end{array}$ \\
\hline
\end{tabular}

*Detection limit not converted to mass units.

Table 27. Statistical summary of atmospheric dry-deposition quality data: Single-dwelling residential site

[Statistical calculations include analytical detection level concentration for those analyses that are reported to be less than detection level. Mass concentrations determined by dividing bucket-washed sample constituent concentration by total solids concentrations and mutiplying by $10^{6}$. $<$, actual value is less than value shown. ., not calculated]

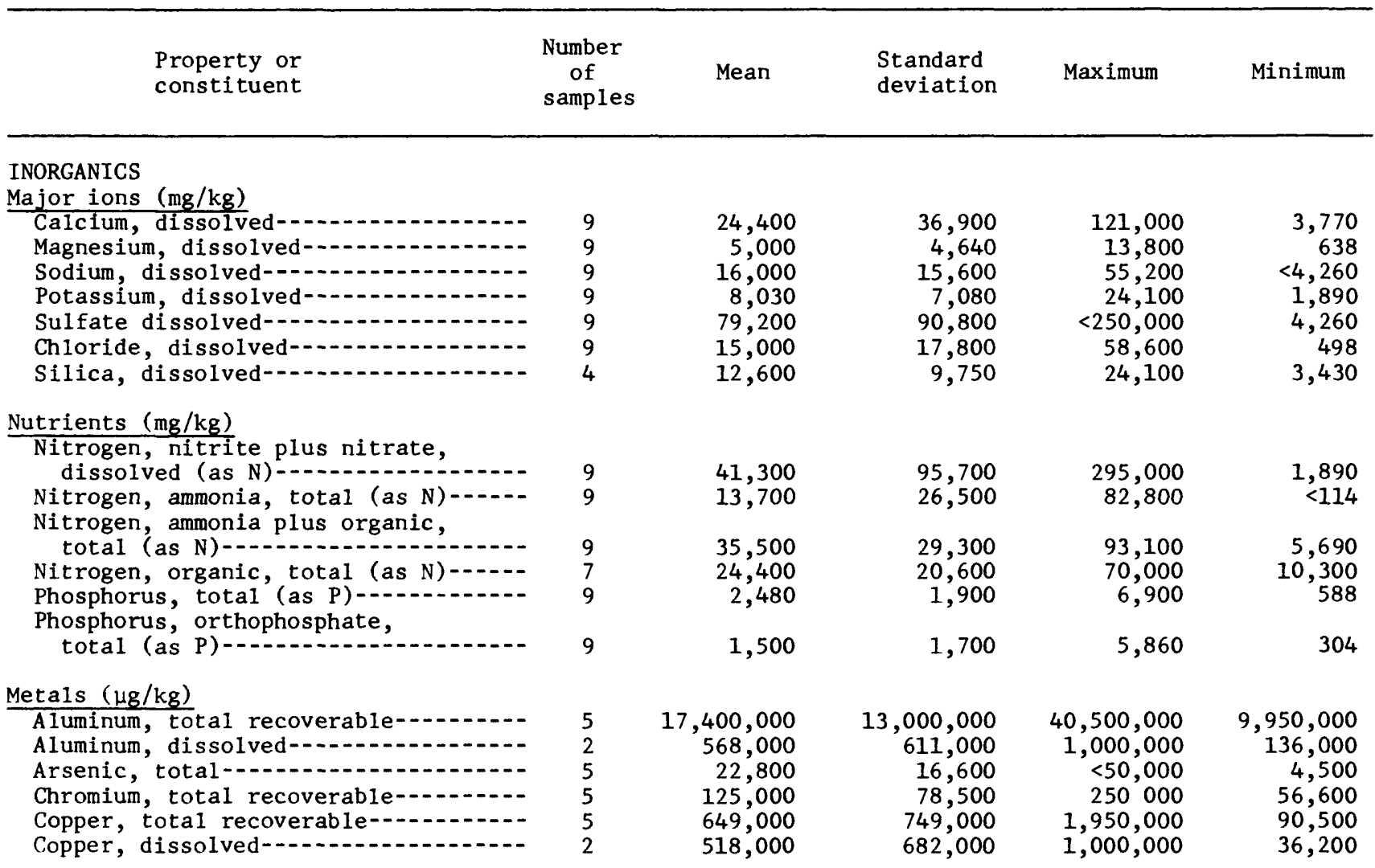


Table 27. Statistical summary of atmospheric dry-deposition quality data: Single-dwelling residential site-Continued

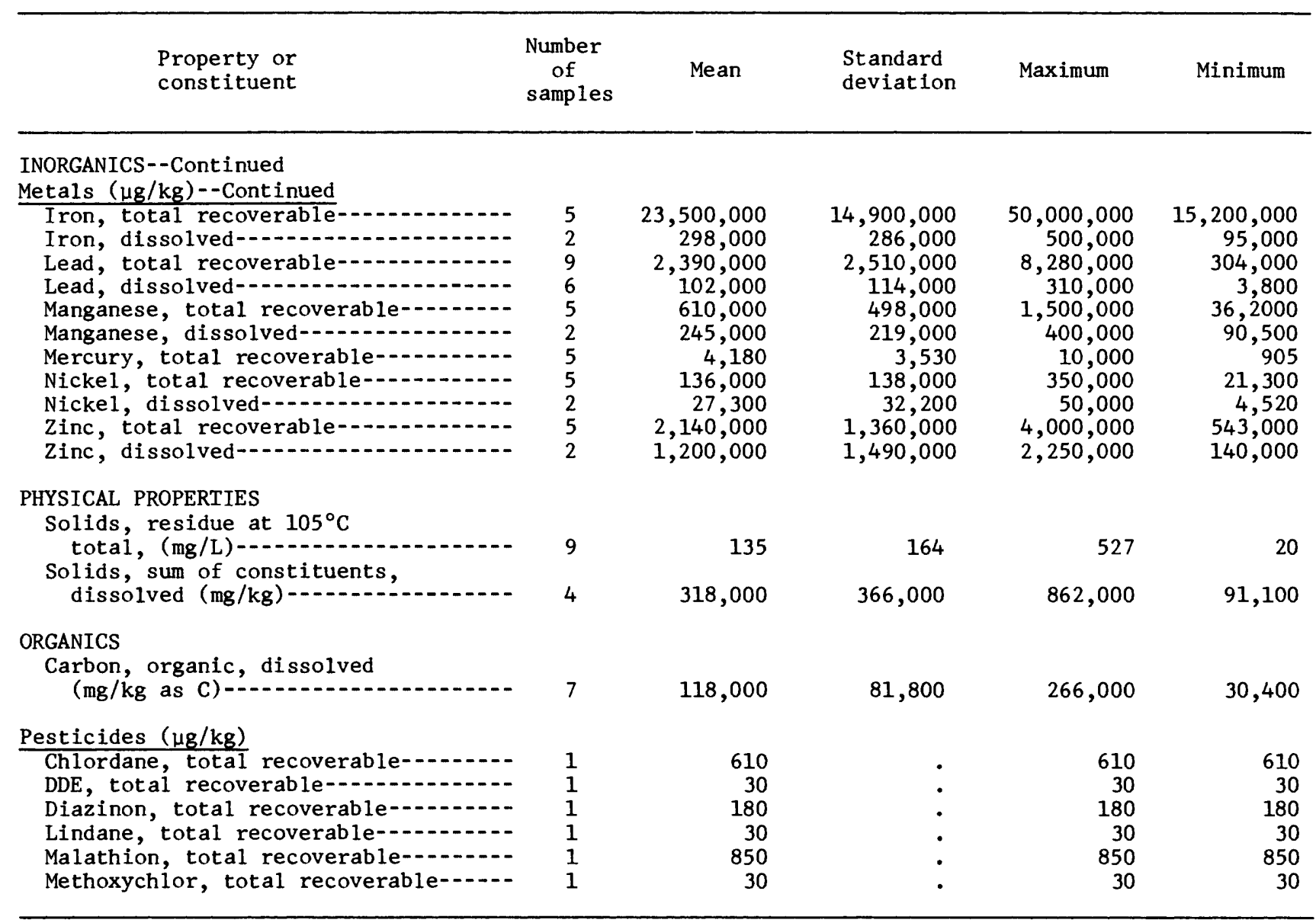

Other pesticides analyzed but not detected (one sample)

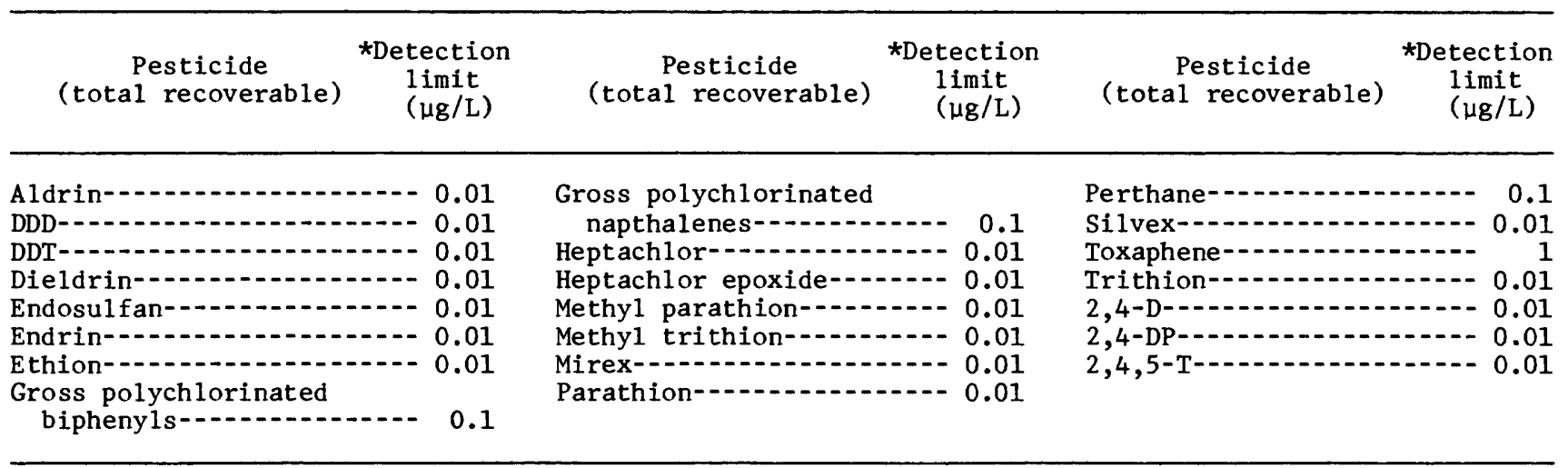

*Detection limit not converted to mass units. 
Table 28. Statistical summary of street-surface particulate quality samples: Industrial catchment

[Statistical calculations include analytical detection limit concentration for those analyses that are reported to be less than detection limit. The analytical detection limit increased with increased quantities of constituents such as oils and greases that interfere with analytical instrumentation. $<$, actual value is less than the value shown]

\begin{tabular}{|c|c|c|c|c|c|c|c|}
\hline $\begin{array}{c}\text { Constituent, } \\
\text { in bottom materials }\end{array}$ & $\begin{array}{l}\text { Number } \\
\text { of } \\
\text { samples }\end{array}$ & Mean & Median & $\begin{array}{l}\text { Standard } \\
\text { error of } \\
\text { mean }\end{array}$ & $\begin{array}{l}\text { Standard } \\
\text { deviation }\end{array}$ & Maximum & Minimum \\
\hline
\end{tabular}

INORGANICS

Major ions $(\mathrm{mg} / \mathrm{kg})$

Calcium, total recoverable-..----

Magnesium, total recoverable-...-

Sodium, total recoverable--...--

Potassium, total recoverable-....- 3

Nutrients (mg/kg)

Nitrogen, nitrite, total (as $\mathrm{N}$ )----

Nitrogen, nitrite plus,

nitrate, total (as N)

Nitrogen, ammonia, total (as N)--- 5

Nitrogen, ammonia plus

organic, total (as N) -............

Nitrogen, total (as N) -.........

Phosphorus, total (as P)

Metals $(\mu g / g)$

Aluminum, total recoverable-.....-

Arsenic, total-...................

Cadmium, total recoverable-......

Chromium, total recoverable-.....-

Copper, total recoverable-......

Iron, total recoverable-......--

Lead, total recoverable-.........-

Manganese, total recoverable-...--

Mercury, total recoverable-.....-

Nickel, total recoverable--......--

Zinc, total recoverable-......-.

OXYGEN DEMAND (mg/kg)

Oxygen demand, chemical,

total

PHYSICAL PROPERTIES ( $\mathrm{mg} / \mathrm{kg}$ )

Residue, loss on ignition-.......

ORGANICS

Carbon, inorganic plus

organic, total ( $\mathrm{g} / \mathrm{kg}$ as $\mathrm{C}) \ldots$

Carbon, inorganic,

total $(\mathrm{g} / \mathrm{kg}$ as $\mathrm{C})$

5

13

11

1.0

3

17

10

$0.1<0.1$

0.0

0.0

0.2

$<0.1$

Pesticides (total recoverable,

\section{$\mu \mathrm{g} / \mathrm{kg})$}

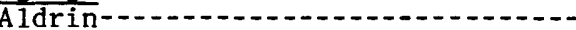

Ch1ordane-1...

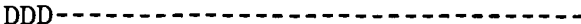

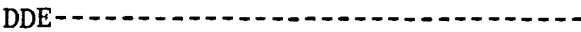

DDT-10.-10

Diazinon---

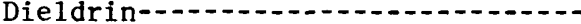

Endosulfan--.-.-.

Endrin--.--

Ethion-1.-.

Heptachlor epoxide-...............

Heptachlor-1...

Lindane-............

$\begin{array}{rr}1.5 & <1.0 \\ 1.40 & 110 \\ 1.3 & <0.5 \\ 12 & 12 \\ 21 & 21 \\ 4.7 & <1.0 \\ 1.2 & 1.2 \\ 1.3 & <0.5 \\ 0.7 & <0.5 \\ 0.8 & <1.0 \\ 1.4 & <0.5 \\ 1.1 & 0.5 \\ 2.6 & 2.1\end{array}$

0.6
33
0.7
1.1
4.3
3.8
0.4
0.7
0.1
0.2
0.6
0.7
0.5
1.4

75

1.5

2.5

9.6

8.6

0.8

1.5

0.2

0.4

1.2

1.6

1.1

$\begin{array}{rr}40 & 30 \\ 40 & 20 \\ <10 & <10 \\ 420 & 310\end{array}$

$7.4<2.0$

$1,000 \quad 300$

$250-347$

$\begin{array}{rr}830 & 780 \\ 4 & 2 \\ <10 & <1 \\ 30 & 10 \\ 54 & 27 \\ 3,700 & 2,000 \\ 300 & 100 \\ 46 & 34 \\ 0.03 & 0.01 \\ <100 & 20 \\ 120 & 49\end{array}$

$65,000 \quad 30,000$

$31,100 \quad 19,900$
$<2 \quad<2$

20

(10


Table 28. Statistical summary of street-surface particulate quality samples: Industrial catchment-Continued

\begin{tabular}{|c|c|c|c|c|c|c|c|}
\hline $\begin{array}{c}\text { Constituent, } \\
\text { in bottom materials }\end{array}$ & $\begin{array}{l}\text { Number } \\
\text { of } \\
\text { samples }\end{array}$ & Mean & Median & $\begin{array}{l}\text { Standard } \\
\text { error of } \\
\text { mean }\end{array}$ & $\begin{array}{l}\text { Standard } \\
\text { deviation }\end{array}$ & Maximum & Minimum \\
\hline \multicolumn{8}{|l|}{$\begin{array}{l}\text { ORGANICS--Continued } \\
\text { Pesticides (total recoverable, } \\
\mu g / \mathrm{kg})-- \text { Continued }\end{array}$} \\
\hline 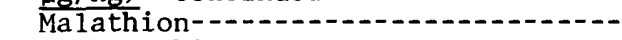 & 5 & 1.0 & $<1.0$ & 0.3 & 0.7 & 2.1 & $<0.1$ \\
\hline Methoxych1or & 5 & 2.9 & $<2.5$ & 1.3 & 3.0 & $<8.0$ & $<0.5$ \\
\hline Methyl parathion- & 5 & 0.8 & $<1.0$ & 0.2 & 0.4 & $<1.0$ & $<0.1$ \\
\hline Methyl trithion & 5 & 0.8 & $<1.0$ & 0.2 & 0.4 & $<1.0$ & $<0.1$ \\
\hline Mirex-1 & 5 & 1.5 & $<1.0$ & 0.6 & 1.4 & $<4.0$ & $<0.5$ \\
\hline Parathion- & 5 & 3.8 & $<1.0$ & 3.1 & 6.8 & 16 & $<0.1$ \\
\hline PCB-10-10 & 5 & 30 & 33 & 3 & 6 & 37 & 23 \\
\hline 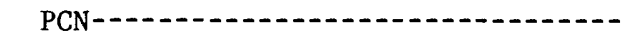 & 2 & 10 & $<10$ & 0.0 & 0.0 & $<10$ & $<10$ \\
\hline Perthane- & 5 & 13 & $<5$ & 7 & 15 & $<40$ & $<5$ \\
\hline Toxaphene- & 5 & 130 & $<50$ & 70 & 150 & $<400$ & $<50$ \\
\hline Trithion- & 5 & 0.8 & $<1.0$ & 0.2 & 0.4 & $<1.0$ & $<0.1$ \\
\hline $2,4-\mathrm{D}-\cdots$ & 2 & 0.5 & $<0.5$ & 0.0 & 0.0 & $<0.5$ & $<0.5$ \\
\hline
\end{tabular}

Table 29. Statistical summary of street-surface particulate quality samples: Single-dwelling residential catchment

[Statistical calculations include analytical detection limit concentration for those analyses that are reported to be less than detection limit. The analytical detection limit increased with increased quantities of constituents such as oils and greases that interfere with analytical instrumentation. $<$, actual value is less than value shown]

\begin{tabular}{|c|c|c|c|c|c|c|c|}
\hline $\begin{array}{l}\text { Constituent, } \\
\text { in bottom materials }\end{array}$ & $\begin{array}{l}\text { Number } \\
\text { of } \\
\text { samples }\end{array}$ & Mean & Median & $\begin{array}{l}\text { Standard } \\
\text { error of } \\
\text { mean }\end{array}$ & $\begin{array}{l}\text { Standard } \\
\text { deviation }\end{array}$ & Maximum & Minimum \\
\hline \multicolumn{8}{|l|}{ INORGANICS } \\
\hline \multicolumn{8}{|l|}{ Major ions $(\mathrm{mg} / \mathrm{kg})$} \\
\hline Calcium, total recoverable & 3 & 70 & 60 & 20 & 40 & 110 & 30 \\
\hline Magnesium, total recoverable-c. & 3 & 20 & 20 & 0 & 0 & 20 & 20 \\
\hline Sodium, total recoverable-1 & 3 & 10 & $<10$ & 0 & 0 & $<10$ & $<10$ \\
\hline Potassium, total recoverable-- & 3 & 760 & 800 & 40 & 60 & 800 & 690 \\
\hline \multicolumn{8}{|l|}{ Nutrients (mg/kg) } \\
\hline $\begin{array}{l}\text { Nitrogen, nitrite, total (as N)--- } \\
\text { Nitrogen, nitrite plus }\end{array}$ & 3 & 2 & $<2$ & 0 & 0 & $>2$ & $<2$ \\
\hline nitrate, total (as $\mathrm{N}$ ) & 5 & 5.5 & 4.1 & 1.7 & 3.9 & 12 & $<2.0$ \\
\hline $\begin{array}{l}\text { Nitrogen, ammonia, total (as N) - - } \\
\text { Nitrogen, ammonia plus }\end{array}$ & 5 & 35 & 31 & 8 & 18 & 64 & 19 \\
\hline organic, total (as N) & 5 & 900 & 1,000 & 130 & 300 & 1,200 & 500 \\
\hline Nitrogen, total (as N) & 4 & 878 & 897 & 168 & 336 & 1,210 & 507 \\
\hline Phosphorus, total (as P) & 5 & 450 & 260 & 190 & 420 & 1,200 & 220 \\
\hline \multicolumn{8}{|l|}{ Metals $(\mu \mathrm{g} / \mathrm{g})$} \\
\hline Aluminum, total recoverable- & 2 & 1,200 & 1,250 & 150 & 210 & 1,400 & 1,100 \\
\hline Arsenic, total & 5 & 2 & 2 & 0 & 1 & 3 & 2 \\
\hline Cadmium, total recoverable & 3 & 4 & $<1$ & 3 & 5 & $<10$ & $<1$ \\
\hline Chromium, total recoverable-.... & 3 & 4 & 4 & 0 & 0 & 4 & 4 \\
\hline Copper, total recoverable-n & 5 & 14 & 12 & 2 & 4 & 18 & $<10$ \\
\hline Iron, total recoverable & 5 & 3,100 & 3,200 & 250 & 570 & 3,600 & 2,100 \\
\hline Lead, total recoverablen............. & 5 & 560 & 510 & 60 & 130 & 790 & 500 \\
\hline Manganese, total recoverable-....- & 2 & 54 & 54 & 11 & 16 & 65 & 43 \\
\hline Mercury, total recoverable-....... & 5 & 0.03 & 0.03 & 0.01 & 0.01 & 0.05 & 0.01 \\
\hline Nickel, total recoverable & 5 & 28 & 10 & 18 & 40 & $<100$ & $<10$ \\
\hline Zinc, total recoverable & 5 & 220 & 85 & 140 & 320 & 800 & 59 \\
\hline
\end{tabular}


Table 29. Statistical summary of street-surface particulate quality samples: Single-dwelling residential catchment-Continued

\begin{tabular}{|c|c|c|c|c|c|c|c|}
\hline $\begin{array}{l}\text { Constituent, } \\
\text { in bottom materials }\end{array}$ & $\begin{array}{l}\text { Number } \\
\text { of } \\
\text { samples }\end{array}$ & Mean & Median & $\begin{array}{l}\text { Standard } \\
\text { error of } \\
\text { mean }\end{array}$ & $\begin{array}{l}\text { Standard } \\
\text { deviation }\end{array}$ & Maximum & Minimum \\
\hline \multicolumn{8}{|l|}{ OXYGEN DEMAND (mg/kg) } \\
\hline Oxygen demand, chemical, total-..- & 5 & 52,000 & 50,000 & 4,100 & 9,200 & 66,000 & 44,000 \\
\hline \multicolumn{8}{|l|}{ PHYSICAL PROPERTIES (mg/kg) } \\
\hline Residue, loss on ignition- & 5 & 62,500 & 58,000 & 10,000 & 22,400 & 98,000 & 36,100 \\
\hline \multicolumn{8}{|l|}{ ORGANICS } \\
\hline $\begin{array}{l}\text { Carbon, inorganic plus organic, } \\
\text { total }(\mathrm{g} / \mathrm{kg} \text { as } \mathrm{C})\end{array}$ & 5 & 21 & 20 & 1.0 & 3 & 25 & 18 \\
\hline total $(\mathrm{g} / \mathrm{kg}$ as $\mathrm{C})$ & 5 & 0.2 & $<1.0$ & 0.1 & 0.3 & 0.7 & $<0.1$ \\
\hline \multicolumn{8}{|l|}{$\frac{\text { Pesticides (total recoverable, }}{\mu \mathrm{g} / \mathrm{kg} \text { ) }}$} \\
\hline 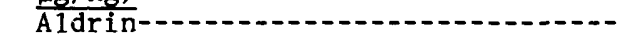 & 5 & 0.9 & $<1.0$ & 0.1 & 0.2 & $<1.0$ & $<0.5$ \\
\hline Chlordane-1 & 5 & 300 & 290 & 46 & 110 & 470 & 170 \\
\hline 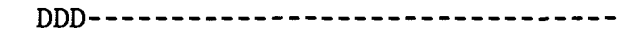 & 5 & 1.5 & $<1.0$ & 0.6 & 1.4 & $<4.0$ & $<0.5$ \\
\hline 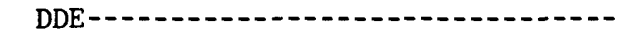 & 5 & 6.5 & 6.0 & 1.3 & 2.8 & 11 & 3.3 \\
\hline DDT & 5 & 17 & 15 & 4 & 8 & 31 & 11 \\
\hline Diazinon-1- & 5 & 7.4 & 6.0 & 2.8 & 6.2 & 18 & 3.0 \\
\hline Dieldrin-10 & 5 & 3.1 & 3.7 & 0.8 & 1.7 & 5.2 & 0.7 \\
\hline Endosulfan- & 5 & 1.5 & $<1.0$ & 0.6 & 1.4 & $<4.0$ & $<0.5$ \\
\hline 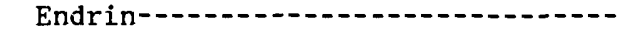 & 5 & 0.9 & $<1.0$ & 0.1 & 0.2 & $<1.0$ & $<0.5$ \\
\hline Ethion-- - - - & 5 & 0.8 & $<1.0$ & 0.2 & 0.4 & $<1.0$ & $<0.1$ \\
\hline Heptachlor epoxide & 5 & 0.9 & $<1.0$ & 0.1 & 0.3 & 1.2 & $<0.5$ \\
\hline Heptachlor & 5 & 1.5 & 1.4 & 0.2 & 0.5 & 2.2 & 1.0 \\
\hline Lindane-c- & 5 & 7.5 & 2.8 & 4.6 & 10 & 26 & 1.5 \\
\hline Malathion- & 5 & 4.1 & 2.9 & 1.6 & 3.6 & 10 & $<1.0$ \\
\hline Methoxychlor & 5 & 2.3 & $<1.0$ & 1.4 & 3.2 & $<8.0$ & $<0.5$ \\
\hline Methy1 parathion- & 5 & 0.8 & $<1.0$ & 0.2 & 0.4 & $<1.0$ & $<0.1$ \\
\hline Methy1 trithion & 5 & 0.8 & $<1.0$ & 0.2 & 0.4 & $<1.0$ & $<0.1$ \\
\hline 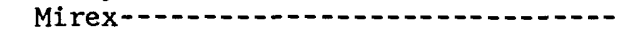 & 5 & 0.9 & $<1.0$ & 0.1 & 0.2 & $<1.0$ & $<0.5$ \\
\hline Parathion- & 5 & 6.4 & $<1.0$ & 5.6 & 13 & 29 & $<0.1$ \\
\hline Gross polychlorinated biphenyls---- & 5 & 21 & 13 & 8 & 17 & 51 & 10 \\
\hline Gross polychlorinated & & & & & & & \\
\hline naphthalenes & 2 & 10 & $<10$ & 0 & 0 & $<10$ & $<10$ \\
\hline Perthane-10 & 5 & 15 & $<10$ & 6 & 14 & $<40$ & $<5$ \\
\hline Toxaphene- & 5 & 150 & $<100$ & 60 & 140 & $<400$ & $<50$ \\
\hline Trithion & 5 & 0.8 & $<1.0$ & 0.2 & 0.4 & $<1.0$ & $<0.1$ \\
\hline $2,4-D-\cdots$ & 2 & 0.5 & $<0.5$ & 0.0 & 0.0 & $<0.5$ & $<0.5$ \\
\hline
\end{tabular}

Table 30. Statistical summary of street-surface particulate quality samples: Multiple-dwelling residential catchment

[Statistical calculations include analytical detection limit concentration for those analyses that are reported to be less than detection limit. The analytical detection limit increased with increased quantities of constituents such as oils and greases that interfere with analytical instrumentation. $<$, actual value is less than value shown]

\begin{tabular}{|c|c|c|c|c|c|c|c|}
\hline $\begin{array}{l}\text { Constituent, } \\
\text { in bottom materials }\end{array}$ & $\begin{array}{l}\text { Number } \\
\text { of } \\
\text { samples }\end{array}$ & Mean & Median & $\begin{array}{l}\text { Standard } \\
\text { error of } \\
\text { mean }\end{array}$ & $\begin{array}{l}\text { Standard } \\
\text { deviation }\end{array}$ & Maximum & Minimum \\
\hline $\begin{array}{l}\text { INORGANICS } \\
\text { Major ions }(\mathrm{mg} / \mathrm{kg})\end{array}$ & & & & & & & \\
\hline $\begin{array}{l}\text { Calcium, total recoverable } \\
\text { Magnesium, total recoverable } \\
\text { Potassium, total recoverable } \\
\text { Sodium, total recoverable }\end{array}$ & $\begin{array}{l}3 \\
3 \\
3 \\
3\end{array}$ & $\begin{array}{r}30 \\
20 \\
530 \\
10\end{array}$ & $\begin{array}{r}30 \\
20 \\
500 \\
<10\end{array}$ & $\begin{array}{r}0 \\
0 \\
60 \\
0.0\end{array}$ & $\begin{array}{r}10 \\
10 \\
100 \\
0.0\end{array}$ & $\begin{array}{r}40 \\
20 \\
640 \\
<10\end{array}$ & $\begin{array}{r}30 \\
10 \\
460 \\
<10\end{array}$ \\
\hline
\end{tabular}


Table 30. Statistical summary of street-surface particulate quality samples: Multiple-dwelling residential catchment-Continued

\begin{tabular}{|c|c|c|c|c|c|c|c|}
\hline $\begin{array}{l}\text { Constituent, } \\
\text { in bottom materials }\end{array}$ & $\begin{array}{l}\text { Number } \\
\text { of } \\
\text { samples }\end{array}$ & Mean & Median & $\begin{array}{l}\text { Standard } \\
\text { error of } \\
\text { mean }\end{array}$ & $\begin{array}{l}\text { Standard } \\
\text { deviation }\end{array}$ & Maximum & Minimum \\
\hline \multicolumn{8}{|l|}{$\begin{array}{l}\text { INORGANICS--Continued } \\
\text { Nutrients }(\mathrm{mg} / \mathrm{kg})\end{array}$} \\
\hline $\begin{array}{l}\text { Nitrogen, nitrite, total (as } \mathrm{N} \text { ) } \\
\text { Nitrogen, nitrite plus nitrate, }\end{array}$ & 3 & 2 & $<2$ & 0.0 & 0.0 & $>2$ & $<2$ \\
\hline total (as N) - & 5 & 7.3 & 5.0 & 2.3 & 5.1 & 15 & $<2.0$ \\
\hline $\begin{array}{l}\text { Nitrogen, ammonia, total (as } \mathrm{N}) \\
\text { Nitrogen, ammonia plus organic, }\end{array}$ & 5 & 30 & 30 & 3.0 & 6.5 & 38 & 22 \\
\hline total (as N) - & 5 & 440 & 470 & 60 & 130 & 570 & 250 \\
\hline Nitrogen, total (as $N$ ) $-\cdots$ & 4 & 429 & 440 & 69 & 138 & 580 & 255 \\
\hline Phosphorus, total (as P) - - & 5 & 210 & 180 & 20 & 60 & 300 & 160 \\
\hline \multicolumn{8}{|l|}{ Metals $(\mu g / g)$} \\
\hline Aluminum, total recoverable-- & 2 & 1,200 & 1,200 & 490 & 690 & 1,700 & 720 \\
\hline Arsenic, total- & 5 & 2 & 2 & 0 & 1 & 2 & 1 \\
\hline Cadmium, total recoverable-c- & 3 & 4 & 1 & 3 & 5 & 10 & 1 \\
\hline Chromium, total recoverable & 3 & 3 & 3 & 0 & 1 & 4 & 3 \\
\hline Copper, total recoverable & 5 & 10 & $<10$ & 2 & 5 & 17 & 5 \\
\hline Iron, total recoverable-... & 5 & 2,400 & 2,400 & 330 & 740 & 3,000 & 1,200 \\
\hline Lead, total recoverable--- & 5 & 330 & 400 & 50 & 110 & 430 & 200 \\
\hline Manganese, total recoverable & 2 & 46 & 46 & 14 & 21 & 60 & 31 \\
\hline Mercury, total recoverable-- & 5 & 0.03 & 0.03 & 0.00 & 0.01 & 0.04 & 0.02 \\
\hline Nickel, total recoverable-- & 5 & 28 & $<10$ & 18 & 40 & $<100$ & 8 \\
\hline Zinc, total recoverable---- & 5 & 72 & 49 & 20 & 45 & 150 & 40 \\
\hline \multicolumn{8}{|l|}{ OXYGEN DEMAND (mg/kg) } \\
\hline Oxygen demand, chemical, total & 5 & 36,000 & 37,000 & 3,900 & 8,700 & 49,000 & 25,000 \\
\hline \multicolumn{8}{|l|}{ PHYSICAL PROPERTIES (mg/kg) } \\
\hline Residue, loss on ignition & 5 & 27,700 & 20,600 & 6,440 & 14,400 & 53,200 & 19,600 \\
\hline \multicolumn{8}{|l|}{ ORGANICS } \\
\hline $\begin{array}{l}\text { Carbon, inorganic plus org } \\
\text { total }(\mathrm{g} / \mathrm{kg} \text { as } \mathrm{C})\end{array}$ & 5 & 12 & 11 & 1 & 1 & 14 & 11 \\
\hline Carbon, inorganic, & 5 & 01 & $<0,7$ & 00 & 00 & $0 ?$ & $<07$ \\
\hline total $(\mathrm{g} / \mathrm{kg}$ as $\mathrm{C})-\ldots$ & 2 & 0.1 & $<0.1$ & 0.0 & 0.0 & 0.2 & 0.1 \\
\hline \multicolumn{8}{|l|}{ Pesticides (total recoverable, } \\
\hline \multicolumn{8}{|l|}{$\mu g / \mathrm{kg})$} \\
\hline Aldrin- & 5 & 0.7 & $<0.5$ & 0.1 & 0.3 & $<1.0$ & $<0.5$ \\
\hline Chlordane-- & 5 & 110 & 110 & 17 & 39 & 160 & 57 \\
\hline DDD & 5 & 0.6 & $<0.5$ & 0.1 & 0.3 & $<1.0$ & $<0.2$ \\
\hline $\mathrm{DDE}-$ & 5 & 5.7 & 4.5 & 1.4 & 3.1 & 10 & 3.1 \\
\hline DDT & 5 & 5.9 & 4.4 & 2.7 & 6.0 & 15 & $<0.5$ \\
\hline Diazinon- & 5 & 8.0 & 3.9 & 4.3 & 9.6 & 25 & 1.8 \\
\hline Dieldrin- & 5 & 1.6 & 1.2 & 0.5 & 1.1 & 2.8 & 0.3 \\
\hline Endosulfan--1 & 5 & 1.8 & $<0.5$ & 1.2 & 2.8 & 6.7 & $<0.2$ \\
\hline Endrin- & 5 & 0.5 & $<0.5$ & 0.2 & 0.4 & $<1.0$ & $<0.1$ \\
\hline Ethion- & 5 & 0.5 & $<0.1$ & 0.2 & 0.5 & $<1.0$ & $<0.1$ \\
\hline Heptachlor epoxide & 5 & 0.7 & $<0.5$ & 0.4 & 0.9 & 2.2 & $<0.1$ \\
\hline Heptachlor & 5 & 1.2 & 1.2 & 0.2 & 0.5 & 1.9 & $<0.8$ \\
\hline Lindane & 5 & 1.6 & 1.5 & 0.5 & 1.0 & 3.3 & 0.6 \\
\hline Malathion- & 5 & 3.1 & 2.1 & 1.5 & 3.4 & 8.7 & $<0.1$ \\
\hline Methoxychlor & 5 & 2.9 & $<2.5$ & 1.3 & 3.0 & $<8.0$ & $<0.5$ \\
\hline Methyl parathion- & 5 & 0.5 & $<0.1$ & 0.2 & 0.5 & $<1.0$ & $<0.1$ \\
\hline Methyl trithion- & 5 & 0.5 & $<0.1$ & 0.2 & 0.5 & $<1.0$ & $<0.1$ \\
\hline Mirex- & 5 & 0.7 & $<0.5$ & 0.1 & 0.2 & $<1.0$ & $<0.5$ \\
\hline Parathion- & 5 & 8.0 & 1.0 & 7.0 & 16 & 36 & $<0.1$ \\
\hline Gross polychlorinated biphenyls---- & 5 & 38 & 38 & 3 & 8 & 49 & 30 \\
\hline Gross polychlorinated & & & & & & & \\
\hline naph thal enes- & 2 & 5.0 & $<5$ & 0 & 0 & $<5$ & $<5$ \\
\hline
\end{tabular}


Table 30. Statistical summary of street-surface particulate quality samples: Multiple-dwelling residential catchment-Continued

\begin{tabular}{|c|c|c|c|c|c|c|c|}
\hline $\begin{array}{l}\text { Constituent, } \\
\text { in bottom materials }\end{array}$ & $\begin{array}{l}\text { Number } \\
\text { of } \\
\text { samples }\end{array}$ & Mean & Median & $\begin{array}{l}\text { Standard } \\
\text { error of } \\
\quad \text { mean }\end{array}$ & $\begin{array}{l}\text { Standard } \\
\text { deviation }\end{array}$ & Maximum & Minimum \\
\hline \multicolumn{8}{|l|}{$\begin{array}{l}\text { ORGANICS--Continued } \\
\text { Pesticides (total recoverable, } \\
\mu \mathrm{g} / \mathrm{kg})-- \text { Continued }\end{array}$} \\
\hline $\begin{array}{l}\text { Perthane- } \\
\text { Toxaphene- } \\
\text { Trithion- } 2,4-\mathrm{D}\end{array}$ & $\begin{array}{l}5 \\
5 \\
5 \\
2\end{array}$ & $\begin{array}{r}6 \\
60 \\
0.5 \\
0.5\end{array}$ & $\begin{array}{r}<5 \\
<50 \\
<0.1 \\
<0.5\end{array}$ & $\begin{array}{r}1 \\
10 \\
0.2 \\
0.0\end{array}$ & $\begin{array}{r}3 \\
30 \\
0.5 \\
0.0\end{array}$ & $\begin{array}{r}<10 \\
<100 \\
<1.0 \\
<0.5\end{array}$ & $\begin{array}{r}<2 \\
<20 \\
<0.1 \\
<0.5\end{array}$ \\
\hline
\end{tabular}

Table 31. Statistical summary of street-surface particulate quality samples: Commercial catchment

[Statistical calculations include analytical detection limit concentration for those analyses that are reported to be less than detection limit. The analytical detection limit increased with increased quantities of constituents such as oils and greases that interfere with analytical instrumentation. $<$, actual value is less than value shown. ., not calculated]

\begin{tabular}{|c|c|c|c|c|c|c|c|}
\hline $\begin{array}{l}\text { Constituent, } \\
\text { in bottom materials }\end{array}$ & $\begin{array}{l}\text { Number } \\
\text { of } \\
\text { samples }\end{array}$ & Mean & Median & $\begin{array}{l}\text { Standard } \\
\text { error of } \\
\text { mean }\end{array}$ & $\begin{array}{l}\text { Standard } \\
\text { deviation }\end{array}$ & Maximum & Minimum \\
\hline \multicolumn{8}{|l|}{ INORGANICS } \\
\hline \multicolumn{8}{|l|}{ Major ions (mg/kg) } \\
\hline Calcium, total recoverable & 4 & 90 & 80 & 10 & 20 & 120 & 70 \\
\hline Magnesium, total recoverable-..... & 4 & 40 & 40 & 0 & 10 & 50 & 30 \\
\hline Sodium, total recoverable-... & 4 & $<10$ & $<10$ & 0.0 & 0.0 & $<10$ & $<10$ \\
\hline Potassium, total recoverable..... & 4 & 950 & 1,000 & 230 & 460 & 1,400 & 500 \\
\hline \multicolumn{8}{|l|}{ Nutrients (mg/kg) } \\
\hline $\begin{array}{l}\text { Nitrogen, nitrate, total (as N)--- } \\
\text { Nitrogen, nitrite plus }\end{array}$ & 4 & 2 & $<2$ & 0.0 & 0.0 & $>2$ & $<2$ \\
\hline nitrate, total (as N) & 6 & 16 & 13 & 5.4 & 13 & 42 & 6.6 \\
\hline $\begin{array}{l}\text { Nitrogen, ammonia, total (as N)-.-- } \\
\text { Nitrogen, ammonia plus organic, }\end{array}$ & - & 48 & 39 & 11 & 28 & 100 & 24 \\
\hline total (as N) & 6 & 1,190 & 1,250 & 190 & 470 & 1,900 & 630 \\
\hline Nitrogen, total (as $\mathrm{N}$ ) & 6 & 1,200 & 1,270 & 193 & 472 & 1,910 & 643 \\
\hline Phosphorus, total (as P) & 6 & 330 & 340 & 40 & 90 & 450 & 180 \\
\hline \multicolumn{8}{|l|}{ Metals $(\mu \mathrm{g} / \mathrm{g})$} \\
\hline Aluminum, total recoverable-....- & 2 & 1,600 & - & 350 & 500 & 1,900 & 1,200 \\
\hline Arsenic, total- & 6 & 4 & 4 & 1 & 2 & 7 & 1 \\
\hline Cadmium, total recoverable-..... & 4 & 4 & 2 & 2 & 4 & $<10$ & 1 \\
\hline Chromium, total recoverable & 4 & 20 & 20 & 0.0 & 0.0 & 20 & 20 \\
\hline Copper, total recoverable & 6 & & & 5 & & 50 & 12 \\
\hline Iron, total recoverable-..- & 6 & 4,800 & 5,000 & 680 & 1,700 & 7,000 & 2,500 \\
\hline Lead, total recoverable & 6 & 770 & 810 & 110 & 270 & 1,000 & 280 \\
\hline Manganese, total recoverable-....- & 2 & 85 & 86 & 24 & 35 & 110 & 61 \\
\hline Mercury, total recoverable-..... & 6 & 0.08 & 0.07 & 0.01 & 0.03 & 0.13 & 0.05 \\
\hline Nickel, total recoverable & 6 & 36 & 26 & 13 & 32 & $<100$ & 10 \\
\hline Zinc, total recoverable & 6 & 410 & 740 & 180 & 440 & 1,300 & 130 \\
\hline \multicolumn{8}{|l|}{ OXYGEN DEMAND (mg/kg) } \\
\hline Oxygen demand, chemical, total-..- & 6 & 120,000 & 120,000 & 9,400 & 23,000 & 150,000 & 91,000 \\
\hline \multicolumn{8}{|l|}{ PHYSICAL PROPERTIES (mg/kg) } \\
\hline Residue, loss on ignition- & 6 & 73,200 & 75,000 & 8,570 & 21,000 & 98,300 & 41,200 \\
\hline
\end{tabular}


Table 31. Statistical summary of street-surface particulate quality samples: Commercial catchment-Continued

\begin{tabular}{|c|c|c|c|c|c|c|c|}
\hline $\begin{array}{c}\text { Constituent, } \\
\text { in bottom materials }\end{array}$ & $\begin{array}{l}\text { Number } \\
\text { of } \\
\text { samples }\end{array}$ & Mean & Median & $\begin{array}{l}\text { Standard } \\
\text { error of } \\
\text { mean }\end{array}$ & $\begin{array}{l}\text { Standard } \\
\text { deviation }\end{array}$ & Maximum & Minimum \\
\hline \multicolumn{8}{|l|}{ ORGANICS } \\
\hline \multicolumn{3}{|l|}{ Carbon, inorganic plus organic, } & 46 & 4 & 11 & 55 & 29 \\
\hline$(\mathrm{g} / \mathrm{kg}$ as $\mathrm{C})$ & 6 & 0.4 & 0.3 & 0.1 & 0.3 & 0.8 & $<0.1$ \\
\hline \multicolumn{8}{|l|}{ Pesticides (total recoverable, } \\
\hline Aldrin- $-\cdots$ & 3 & 1.8 & $<1.0$ & 1.1 & 1.9 & $<4.0$ & $<0.5$ \\
\hline Chlordane-1. & 3 & 1,400 & 420 & 1,000 & 1,800 & 3,400 & 280 \\
\hline 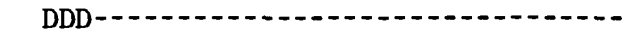 & 3 & 4.3 & $<4.0$ & 2.0 & 3.5 & 7.9 & $<1.0$ \\
\hline DDE-10 & 3 & 1.8 & $<1.0$ & 1.1 & 1.9 & $<4.0$ & $<0.5$ \\
\hline DDT $-0^{-6}$ & 3 & 7.8 & 3.3 & 5.7 & 9.8 & 19 & $<1.0$ \\
\hline Diazinon- -1 & 3 & 41 & 26 & 20 & 34 & 80 & 16 \\
\hline Dieldrin & 3 & 32 & 6.8 & 28 & 49 & 89 & 1.2 \\
\hline Endosulfan & 3 & $1 . \overline{8}$ & $<1.0$ & 1.1 & 1.9 & $<4.0$ & $<0.5$ \\
\hline Endrin- & 3 & 1.8 & $<1.0$ & 1.1 & 1.9 & $<4.0$ & $<0.5$ \\
\hline Ethion- & 3 & 0.7 & $<1.0$ & 0.3 & 0.5 & $<1.0$ & $<0.1$ \\
\hline Heptachlor epoxide & 3 & 16 & 9.9 & 9.9 & 17 & 35 & 2.4 \\
\hline Heptachlor & 3 & 2.0 & 2.2 & 0.7 & 1.2 & 3.0 & 0.7 \\
\hline Lindane & 3 & 3.5 & 4.1 & 0.9 & 1.3 & 4.8 & 1.7 \\
\hline Malathion--...- & 3 & 12 & 15 & 3.9 & 6.8 & 17 & 4.4 \\
\hline 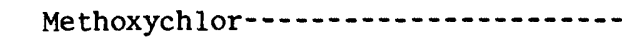 & 3 & 3.2 & $<1.0$ & 2.4 & 4.2 & $<8.0$ & $<0.5$ \\
\hline Methyl parathion & 3 & 0.7 & $<1.0$ & 0.3 & 0.5 & $<1.0$ & $<0.1$ \\
\hline Methy1 trithion & 3 & 0.7 & $<1.0$ & 0.3 & 0.5 & $<1.0$ & $<0.1$ \\
\hline Mirex-c.s. & 3 & 1.8 & $<1.0$ & 1.1 & 1.9 & $<4.0$ & $<0.5$ \\
\hline Parathion- & 3 & 13 & $<1.0$ & 12 & 22 & 38 & $<0.1$ \\
\hline Gross polychlorinated biphenyls & 3 & 630 & 820 & 210 & 360 & 860 & 220 \\
\hline \multicolumn{8}{|l|}{ Gross polychlorinated } \\
\hline naph tha lenes & 0 & - & 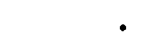 & - & • & . & - \\
\hline Perthane- & 3 & 18 & $<10$ & 11 & 19 & $<40$ & $<5$ \\
\hline Toxaphene- & 3 & 180 & $<100$ & 110 & 190 & $<400$ & $<50$ \\
\hline Trithion- & 3 & 0.7 & $<1.0$ & 0.3 & 0.5 & $<1.0$ & $<0.1$ \\
\hline $2,4-D \cdots$ & 2 & 0.5 & $<0.5$ & 0.0 & 0.0 & $<0.5$ & $<0.5$ \\
\hline
\end{tabular}


Table 32. Percentage of runoff load attributable to rainfall load for the industrial and two residential catchments

[Rainfall total, in inches. Numbered columns below constituent names indicate (1) Rainfall drainoff load, in pounds; (2) Total runoff load, in pounds; (3) value of rainfall load to runoff load, in percent. ., no data available]

a. Industrial catchment

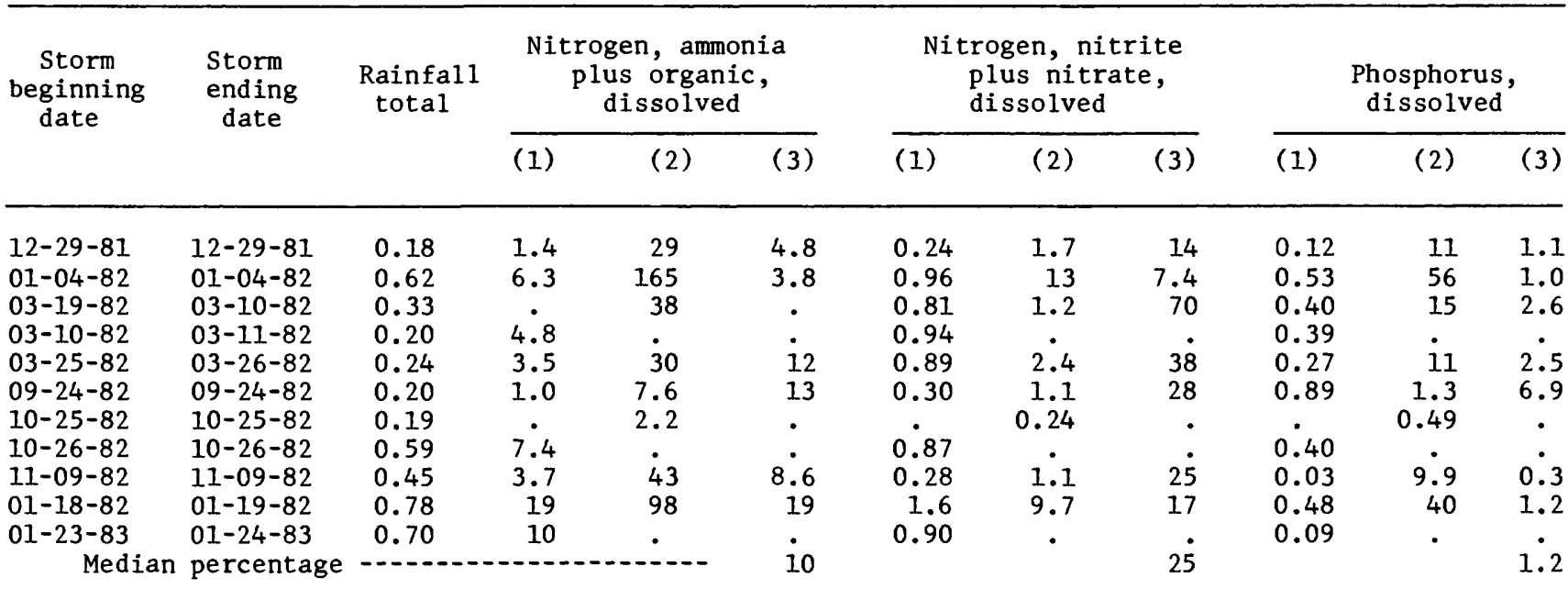

\begin{tabular}{|c|c|c|c|c|c|c|c|c|c|c|}
\hline \multirow{2}{*}{$\begin{array}{l}\text { Storm } \\
\text { beginning } \\
\text { date }\end{array}$} & \multirow{2}{*}{$\begin{array}{l}\text { Storm } \\
\text { ending } \\
\text { date }\end{array}$} & \multicolumn{3}{|c|}{$\begin{array}{l}\text { Oxygen demand, chemical, } \\
0.25 \mathrm{~N} \text { dichromate }\end{array}$} & \multicolumn{3}{|c|}{$\begin{array}{l}\text { Carbon, organic, } \\
\text { dissolved (as C) }\end{array}$} & \multicolumn{3}{|c|}{$\begin{array}{l}\text { Iron, total } \\
\text { recoverable }\end{array}$} \\
\hline & & (1) & (2) & (3) & (1) & (2) & (3) & (1) & (2) & (3) \\
\hline $\begin{array}{r}12-28-81 \\
01-04-82 \\
03-09-82 \\
03-10-82 \\
03-25-82 \\
09-24-82 \\
10-25-82 \\
10-26-82 \\
11-09-82 \\
01-18-83 \\
01-23-83 \\
\text { Median }\end{array}$ & $\begin{array}{c}12-29-81 \\
01-04-82 \\
03-10-82 \\
03-11-82 \\
03-26-82 \\
09-24-82 \\
10-25-82 \\
10-26-82 \\
11-09-82 \\
01-19-83 \\
01-24-83 \\
\text { percentage }\end{array}$ & $\begin{array}{r}27 \\
128 \\
42 \\
67 \\
54 \\
. \\
181 \\
28 \\
162 \\
90 \\
-\end{array}$ & $\begin{array}{r}952 \\
6,710 \\
930 \\
709 \\
\dot{0} \\
1,670 \\
\dot{0} \\
\end{array}$ & $\begin{array}{l}2.9 \\
1.9 \\
4.5 \\
7.6 \\
\dot{0} \\
\dot{1.7} \\
\dot{0} \\
\dot{0} .9\end{array}$ & $\begin{array}{r}4.7 \\
55 \\
7.3 \\
19 \\
8.3 \\
. \\
30 \\
7.7 \\
44 \\
36\end{array}$ & $\begin{array}{c}128 \\
962 \\
480 \\
409 \\
\dot{.} \\
170 \\
\dot{.}\end{array}$ & $\begin{array}{c}3.6 \\
5.8 \\
1.5 \\
2.0 \\
. \\
\dot{4} \\
.5 \\
\dot{3.6}\end{array}$ & $\begin{array}{c}\dot{ } \\
\dot{ } \\
\dot{0} \\
0.88 \\
0.11 \\
0.27 \\
0.99 \\
0.97 \\
0.09\end{array}$ & $\begin{array}{c}14 \\
158 \\
9.5 \\
\cdot \\
8.3 \\
3.7 \\
1.2 \\
\dot{26} \\
183 \\
\cdot\end{array}$ & $\begin{array}{c}\dot{.} \\
\dot{.} \\
\dot{24} \\
9.2 \\
3.8 \\
0.5 \\
6.5\end{array}$ \\
\hline
\end{tabular}

\begin{tabular}{|c|c|c|c|c|c|c|c|c|c|c|}
\hline \multirow{2}{*}{$\begin{array}{l}\text { Storm } \\
\text { beginning } \\
\text { date }\end{array}$} & \multirow{2}{*}{$\begin{array}{l}\text { Storm } \\
\text { ending } \\
\text { date }\end{array}$} & \multicolumn{3}{|c|}{$\begin{array}{l}\text { Lead, total } \\
\text { recoverable }\end{array}$} & \multicolumn{3}{|c|}{$\begin{array}{l}\text { Nickel, total } \\
\text { recoverable }\end{array}$} & \multicolumn{3}{|c|}{$\begin{array}{l}\text { Zinc, total } \\
\text { recoverable }\end{array}$} \\
\hline & & (1) & (2) & (3) & (1) & (2) & (3) & (1) & (2) & (3) \\
\hline $\begin{array}{r}12-29-81 \\
01-04-82 \\
03-09-82 \\
03-10-82 \\
03-25-82 \\
09-24-82 \\
10-25-82 \\
10-26-82 \\
11-09-82 \\
01-18-83 \\
01-23-83 \\
\text { Median }\end{array}$ & $\begin{array}{c}12-29-81 \\
01-04-82 \\
03-10-82 \\
03-11-82 \\
03-26-82 \\
09-24-82 \\
10-25-82 \\
10-26-82 \\
11-09-82 \\
01-19-83 \\
01-24-83 \\
\text { percentage }\end{array}$ & $\begin{array}{r}0.08 \\
0.02 \\
0.02 \\
0.03 \\
0.02 \\
<0.01 \\
0.03 \\
0.02 \\
0.03 \\
0.02 \\
\end{array}$ & $\begin{array}{l}0.15 \\
1.2 \\
0.11 \\
. \\
0.10 \\
0.02 \\
0.01 \\
0.24 \\
1.3 \\
.0 .\end{array}$ & $\begin{array}{c}6.7 \\
18 \\
\dot{30} \\
100 \\
\dot{8.3} \\
2.3 \\
\dot{13}\end{array}$ & $\begin{array}{c}\dot{ } \\
\dot{0} \\
<0.01 \\
<0.01 \\
0.03 \\
0.03 \\
0.02 \\
0.01\end{array}$ & $\begin{array}{c}0.04 \\
0.32 \\
0.01 \\
0.05 \\
0.05 \\
0.01 \\
<0.01 \\
0.05 \\
0.41 \\
.\end{array}$ & $\begin{array}{l}\dot{ } \\
\dot{ } \\
\dot{ } \\
\dot{6} \\
60 \\
4.9 \\
32\end{array}$ & $\begin{array}{c}\dot{ } \\
\dot{0} \\
\dot{0} \\
0.01 \\
0.20 \\
0.65 \\
\dot{0}\end{array}$ & $\begin{array}{l}0.88 \\
6.1 \\
0.94 \\
\dot{0.98} \\
\dot{0} \\
\dot{1.6} \\
\dot{.}\end{array}$ & $1 \dot{2}$ \\
\hline
\end{tabular}


Table 32. Percentage of runoff load attributable to rainfall load for the industrial and two residential catchments-Continued b. Single-dwelling residential catchment

\begin{tabular}{|c|c|c|c|c|c|c|c|c|c|c|c|}
\hline \multirow[t]{2}{*}{$\begin{array}{l}\text { Storm } \\
\text { beginning } \\
\text { date }\end{array}$} & \multirow[t]{2}{*}{$\begin{array}{l}\text { Storm } \\
\text { ending } \\
\text { date }\end{array}$} & \multirow[t]{2}{*}{$\begin{array}{l}\text { Rainfall } \\
\text { total }\end{array}$} & \multicolumn{3}{|c|}{$\begin{array}{l}\text { Nitrogen, ammonia } \\
\text { plus organic, } \\
\text { dissolved }\end{array}$} & \multicolumn{3}{|c|}{$\begin{array}{l}\text { Nitrogen, nitrite } \\
\text { plus nitrate, } \\
\text { dissolved }\end{array}$} & \multicolumn{3}{|c|}{$\begin{array}{l}\text { Phosphorus, } \\
\text { dissolved }\end{array}$} \\
\hline & & & (1) & (2) & (3) & (1) & (2) & (3) & (1) & (2) & (3) \\
\hline $\begin{array}{l}03-25-82 \\
03-28-82 \\
03-31-82 \\
09-24-82 \\
10-25-82 \\
10-26-82 \\
01-18-83 \\
01-24-83 \\
02-28-83 \\
03-16-83 \\
03-23-83 \\
\text { Median }\end{array}$ & $\begin{array}{l}03-26-82 \\
03-29-82 \\
03-31-82 \\
09-24-82 \\
10-25-82 \\
10-26-82 \\
01-19-83 \\
01-24-83 \\
03-01-83 \\
03-16-83 \\
03-23-83 \\
\text { percentage }\end{array}$ & $\begin{array}{l}0.20 \\
0.45 \\
0.95 \\
0.22 \\
0.09 \\
0.69 \\
0.85 \\
0.74 \\
1.11 \\
0.40 \\
0.57 \\
\end{array}$ & $\begin{array}{c}0.85 \\
1.8 \\
1.8 \\
. \\
3.7 \\
2.5 \\
1.5 \\
3.2 \\
1.1 \\
1.7 \\
\end{array}$ & $\begin{array}{l}1.5 \\
3.4 \\
6.9 \\
1.3 \\
8.2 \\
6.3 \\
8.5 \\
4.5 \\
2.3 \\
4.3 \\
. . .\end{array}$ & $\begin{array}{r}57 \\
53 \\
. \\
4 \dot{5} \\
40 \\
18 \\
72 \\
48 \\
40 \\
46\end{array}$ & $\begin{array}{l}0.29 \\
0.33 \\
0.20 \\
0.36 \\
0.37 \\
0.36 \\
0.50 \\
0.64 \\
0.75 \\
0.28\end{array}$ & $\begin{array}{r}0.42 \\
. \\
0.87 \\
1.9 \\
0.26 \\
1.2 \\
0.86 \\
2.0 \\
0.90 \\
0.82 \\
0.43\end{array}$ & $\begin{array}{r}69 \\
23 \\
19 \\
31 \\
42 \\
25 \\
71 \\
91 \\
65 \\
42\end{array}$ & $\begin{array}{l}0.03 \\
0.02 \\
0.05 \\
0.08 \\
0.04 \\
0.07 \\
0.05 \\
0.06 \\
0.05 \\
0.03\end{array}$ & $\begin{array}{l}0.18 \\
0.53 \\
0.59 \\
0.08 \\
0.72 \\
0.72 \\
0.70 \\
0.58 \\
0.25 \\
0.43\end{array}$ & $\begin{array}{l}17 \\
9.4 \\
14 \\
5.6 \\
9.7 \\
7.1 \\
10 \\
20 \\
7.0 \\
9.7\end{array}$ \\
\hline
\end{tabular}

\begin{tabular}{|c|c|c|c|c|c|c|c|c|c|c|}
\hline \multirow{2}{*}{$\begin{array}{l}\text { Storm } \\
\text { beginning } \\
\text { date }\end{array}$} & \multirow{2}{*}{$\begin{array}{l}\text { Storm } \\
\text { ending } \\
\text { date }\end{array}$} & \multicolumn{3}{|c|}{$\begin{array}{l}\text { Oxygen demand, chemical, } \\
0.25 \mathrm{~N} \text { dichromate }\end{array}$} & \multicolumn{3}{|c|}{$\begin{array}{l}\text { Carbon, organic, } \\
\text { dissolved (as C) }\end{array}$} & \multicolumn{3}{|c|}{$\begin{array}{l}\text { Iron, total } \\
\text { recoverable }\end{array}$} \\
\hline & & (1) & (2) & (3) & (1) & (2) & (3) & (1) & (2) & (3) \\
\hline $\begin{array}{l}03-25-82 \\
03-28-82 \\
03-31-82 \\
09-24-82 \\
10-25-82 \\
10-26-82 \\
01-18-83 \\
01-24-83 \\
02-28-83 \\
03-16-83 \\
03-23-83 \\
\text { Median }\end{array}$ & $\begin{array}{c}03-26-82 \\
03-29-82 \\
03-31-82 \\
09-24-82 \\
10-25-82 \\
10-26-82 \\
01-19-83 \\
01-24-83 \\
03-01-83 \\
03-16-83 \\
03-23-83 \\
\text { percentage }\end{array}$ & $\begin{array}{r}20 \\
22 \\
60 \\
. \\
37 \\
62 \\
50 \\
64 \\
33 \\
49\end{array}$ & $\begin{array}{r}85 \\
36 \dot{6} \\
: \\
\dot{ } \\
235 \\
173 \\
79 \\
120 \\
\end{array}$ & $\begin{array}{r}23 \\
16 \\
\dot{ } \\
\dot{ } \\
\dot{2} \\
21 \\
37 \\
42 \\
40 \\
30\end{array}$ & $\begin{array}{c}4.0 \\
6.8 \\
: \\
\dot{0} \\
8.5 \\
\dot{10} \\
15 \\
5.4 \\
11\end{array}$ & $\begin{array}{r}66 \\
747 \\
\dot{ } \\
\dot{ } \\
101 \\
28 \\
74 \\
77\end{array}$ & $\begin{array}{c}6.1 \\
\dot{1} \\
\dot{1} \\
\dot{10} \\
54 \\
7.3 \\
14 \\
10\end{array}$ & $\begin{array}{c}\dot{.} \\
0.46 \\
0.30 \\
0.33 \\
0.33 \\
0.20 \\
0.06 \\
0.28 \\
0.17\end{array}$ & $\begin{array}{r}0.30 \\
4.5 \\
6.0 \\
1.6 \\
18 \\
4.4 \\
11 \\
30 \\
1.3 \\
2.7\end{array}$ & $\begin{array}{r}. \\
\dot{7} \\
7.7 \\
19 \\
1.8 \\
7.5 \\
1.8 \\
0.2 \\
22 \\
6.3 \\
6.9\end{array}$ \\
\hline
\end{tabular}

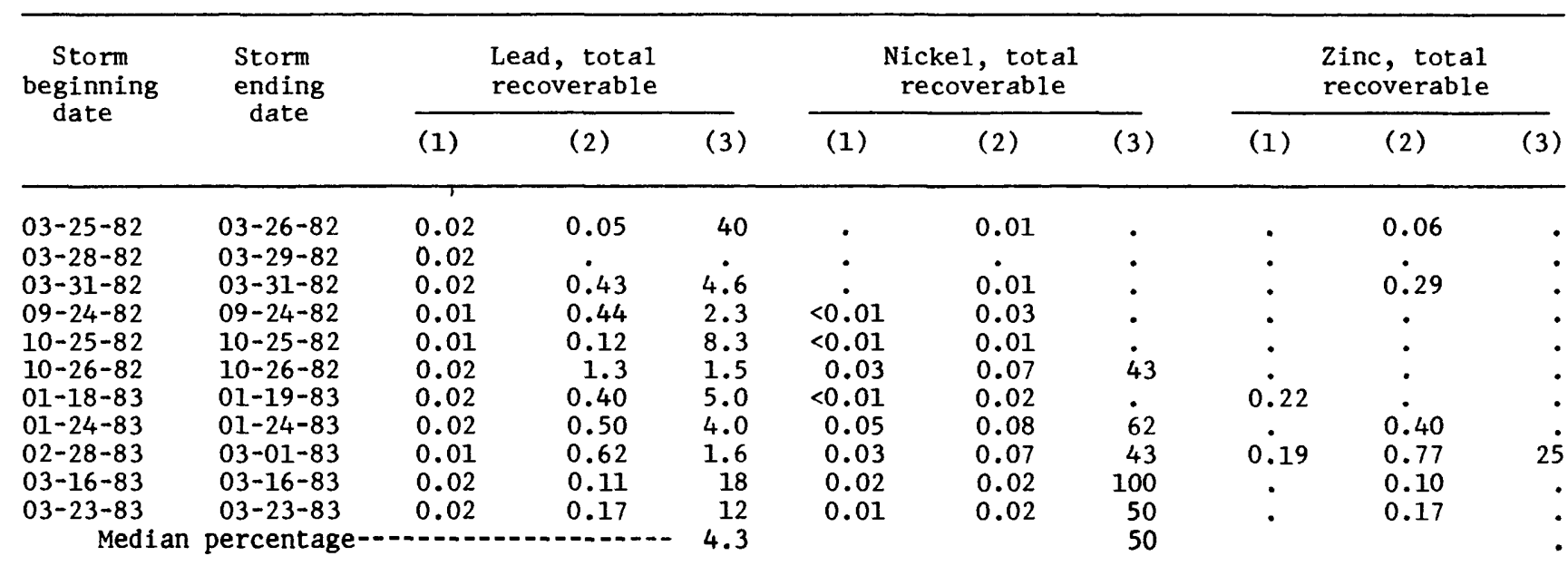


Table 32. Percentage of runoff load attributable to rainfall load for the industrial and two residential catchments-Continued c. Multiple-dwelling residential catchment

\begin{tabular}{|c|c|c|c|c|c|c|c|c|c|c|c|}
\hline \multirow[t]{2}{*}{$\begin{array}{l}\text { Storm } \\
\text { beginning } \\
\text { date }\end{array}$} & \multirow[t]{2}{*}{$\begin{array}{l}\text { Storm } \\
\text { ending } \\
\text { date }\end{array}$} & \multirow[t]{2}{*}{$\begin{array}{c}\text { Rainfall } \\
\text { total }\end{array}$} & \multicolumn{3}{|c|}{$\begin{array}{l}\text { Nitrogen, ammonia } \\
\text { plus organic, } \\
\text { dissolved }\end{array}$} & \multicolumn{3}{|c|}{$\begin{array}{l}\text { Nitrogen, nitrite } \\
\text { plus nitrate, } \\
\text { dissolved }\end{array}$} & \multicolumn{3}{|c|}{$\begin{array}{c}\text { Phosphorus, } \\
\text { dissolved }\end{array}$} \\
\hline & & & (1) & (2) & (3) & (1) & (2) & (3) & (1) & (2) & (3) \\
\hline $\begin{array}{l}12-29-81 \\
01-04-82 \\
09-24-82 \\
10-26-82 \\
11-09-82 \\
01-18-83 \\
01-24-83 \\
03-16-83 \\
03-23-83 \\
\text { Median }\end{array}$ & $\begin{array}{l}12-30-81 \\
01-04-82 \\
09-24-82 \\
10-26-82 \\
11-09-82 \\
01-19-83 \\
01-24-83 \\
03-16-83 \\
03-23-83 \\
\text { percentage }\end{array}$ & $\begin{array}{l}0.38 \\
0.83 \\
0.22 \\
0.69 \\
0.45 \\
0.85 \\
0.74 \\
0.40 \\
0.57 \\
\end{array}$ & $\begin{array}{c}0.56 \\
1.6 \\
5.4 \\
1.6 \\
3.0 \\
1.7 \\
1.6 \\
3.1 \\
\end{array}$ & $\begin{array}{r}1.1 \\
2.7 \\
5.1 \\
24 \\
2.5 \\
7.1 \\
5.6 \\
2.0 \\
4.7 \\
--.\end{array}$ & $\begin{array}{r}51 \\
59 \\
2 \\
22 \\
64 \\
43 \\
30 \\
78 \\
66 \\
55\end{array}$ & $\begin{array}{l}0.12 \\
0.27 \\
0.41 \\
0.54 \\
0.21 \\
0.43 \\
0.57 \\
1.0 \\
0.52\end{array}$ & $\begin{array}{r}0.34 \\
0.59 \\
1.5 \\
1.2 \\
0.64 \\
1.3 \\
1.1 \\
1.8 \\
0.84\end{array}$ & $\begin{array}{l}35 \\
46 \\
27 \\
45 \\
33 \\
33 \\
52 \\
56 \\
62 \\
45\end{array}$ & $\begin{array}{l}0.02 \\
0.03 \\
0.10 \\
0.05 \\
0.02 \\
0.09 \\
0.06 \\
0.07 \\
0.05\end{array}$ & $\begin{array}{l}0.19 \\
0.64 \\
0.53 \\
1.1 \\
0.36 \\
1.6 \\
0.50 \\
0.33 \\
0.42\end{array}$ & $\begin{array}{r}11 \\
4.7 \\
19 \\
4.5 \\
5.6 \\
5.6 \\
12 \\
21 \\
12 \\
11\end{array}$ \\
\hline
\end{tabular}

\begin{tabular}{|c|c|c|c|c|c|c|c|c|c|c|}
\hline \multirow{2}{*}{$\begin{array}{l}\text { Storm } \\
\text { beginning } \\
\text { date }\end{array}$} & \multirow{2}{*}{$\begin{array}{l}\text { Storm } \\
\text { ending } \\
\text { date }\end{array}$} & \multicolumn{3}{|c|}{$\begin{array}{l}\text { Oxygen demand, chemical, } \\
0.25 \mathrm{~N} \text { dichromate }\end{array}$} & \multicolumn{3}{|c|}{$\begin{array}{l}\text { Carbon, organic, } \\
\text { dissolved (as C) }\end{array}$} & \multicolumn{3}{|c|}{$\begin{array}{l}\text { Iron, total } \\
\text { recoverable }\end{array}$} \\
\hline & & (1) & (2) & (3) & (1) & (2) & (3) & (1) & (2) & (3) \\
\hline $12-29-81$ & $12-30-81$ & 13 & 83 & 16 & 2.6 & 8.1 & 32 & . & 7.7 & • \\
\hline $01-04-82$ & $01-04-82$ & 36 & 163 & 22 & 6.3 & 27 & 23 & & 24 & \\
\hline $09-24-82$ & $09-24-82$ & & & & & -7 & . & 0.53 & 21 & 2.5 \\
\hline $10-26-82$ & $10-26-82$ & 54 & & & 12 & 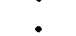 & & 0.48 & 148 & 0.3 \\
\hline $11-09-82$ & $11-09-82$ & 23 & 137 & 17 & 8.7 & 20 & $4 \dot{4}$ & 0.64 & 6.4 & 10 \\
\hline $01-18-83$ & $01-19-83$ & 73 & & & 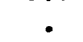 & . & $\because$ & 0.39 & 26 & 1.5 \\
\hline $01-24-83$ & $01-24-83$ & 57 & $350^{\circ}$ & 16 & i2 & 63 & 19 & 0.23 & 38 & 0.6 \\
\hline $03-16-83$ & $03-16-83$ & 44 & 245 & 18 & 7.3 & 73 & 10 & 0.38 & 9.1 & 4.2 \\
\hline $03-23-83$ & $03-23-83$ & 89 & 200 & 45 & 21 & 126 & 17 & 0.32 & 13 & 2.5 \\
\hline Medial & percentage & & & 17 & & & 21 & & & 2.5 \\
\hline
\end{tabular}

\begin{tabular}{|c|c|c|c|c|c|c|c|c|c|c|}
\hline \multirow{2}{*}{$\begin{array}{l}\text { Storm } \\
\text { beginning } \\
\text { date }\end{array}$} & \multirow{2}{*}{$\begin{array}{l}\text { Storm } \\
\text { ending } \\
\text { date }\end{array}$} & \multicolumn{3}{|c|}{$\begin{array}{l}\text { Lead, total } \\
\text { recoverable }\end{array}$} & \multicolumn{3}{|c|}{$\begin{array}{l}\text { Nickel, total } \\
\text { recoverable }\end{array}$} & \multicolumn{3}{|c|}{$\begin{array}{l}\text { Zinc, total } \\
\text { recoverable }\end{array}$} \\
\hline & & (1) & (2) & (3) & (1) & (2) & (3) & (1) & (2) & (3) \\
\hline $\begin{array}{l}12-29-81 \\
01-04-82 \\
09-24-82 \\
10-26-82 \\
11-09-82 \\
01-18-83 \\
01-24-83 \\
03-16-83 \\
03-23-83 \\
\text { Median }\end{array}$ & $\begin{array}{c}12-30-81 \\
01-04-82 \\
09-24-82 \\
10-26-82 \\
11-09-82 \\
01-19-83 \\
01-24-83 \\
03-16-83 \\
03-23-83 \\
\text { percentage }\end{array}$ & $\begin{array}{l}0.01 \\
0.01 \\
0.02 \\
0.01 \\
0.02 \\
0.02 \\
0.03 \\
0.04 \\
-\end{array}$ & $\begin{array}{l}0.20 \\
0.66 \\
0.35 \\
1.5 \\
0.21 \\
0.83 \\
0.81 \\
0.18 \\
0.33 \\
-. .-\end{array}$ & $\begin{array}{r}1.5 \\
2.9 \\
1.3 \\
4.8 \\
2.4 \\
2.5 \\
17 \\
12 \\
3.8\end{array}$ & $\begin{array}{c}. \\
<0.01 \\
0.05 \\
0.01 \\
<0.01 \\
0.06 \\
0.02 \\
0.02\end{array}$ & $\begin{array}{l}0.02 \\
0.05 \\
0.08 \\
0.45 \\
0.02 \\
0.10 \\
0.12 \\
0.05 \\
0.05\end{array}$ & $\begin{array}{l}\dot{.} \\
\dot{11} \\
50 \\
\dot{50} \\
40 \\
40 \\
40\end{array}$ & $\begin{array}{c}\dot{ } \\
\dot{0} \\
0.11 \\
0.26 \\
\dot{.}\end{array}$ & $\begin{array}{c}0.18 \\
0.58 \\
. \\
0.23 \\
0.75 \\
0.31 \\
0.37\end{array}$ & $\begin{array}{r}\dot{ } \\
\dot{48} \\
\dot{ } \\
\dot{ } \\
\dot{ }\end{array}$ \\
\hline
\end{tabular}


Table 33. Summary of pesticides detected in rainfall, runoff, atmospheric dry-deposition, and street-surface particulate samples [ND, not detected; D, detected; ., no data available]

\begin{tabular}{|c|c|c|c|c|c|c|c|c|}
\hline \multirow{2}{*}{$\begin{array}{l}\text { Pesticide } \\
\text { (total } \\
\text { recoverable) }\end{array}$} & \multicolumn{2}{|c|}{ Rainfall } & \multicolumn{2}{|c|}{ Runoff } & \multicolumn{2}{|c|}{$\begin{array}{c}\text { Atmospheric } \\
\text { dry deposition }\end{array}$} & \multicolumn{2}{|c|}{$\begin{array}{c}\text { Street-surface } \\
\text { particulate }\end{array}$} \\
\hline & $\begin{array}{l}\text { Number } \\
\text { of } \\
\text { samples }\end{array}$ & $\begin{array}{c}\text { Detection } \\
\text { status }\end{array}$ & $\begin{array}{l}\text { Number } \\
\text { of } \\
\text { samples }\end{array}$ & $\begin{array}{c}\text { Detection } \\
\text { status }\end{array}$ & $\begin{array}{l}\text { Number } \\
\text { of } \\
\text { samples }\end{array}$ & $\begin{array}{c}\text { Detection } \\
\text { status }\end{array}$ & $\begin{array}{l}\text { Number } \\
\text { of } \\
\text { samples }\end{array}$ & $\begin{array}{c}\text { Detection } \\
\text { status }\end{array}$ \\
\hline \multicolumn{9}{|l|}{ Gross measures } \\
\hline \multirow{2}{*}{$\begin{array}{l}\text { Polychlorinated } \\
\text { biphenyls } \\
\text { Polychlorinated } \\
\text { napthalenes }\end{array}$} & 50 & ND & 86 & $\mathrm{D}$ & 2 & ND & 18 & $D$ \\
\hline & 50 & $\mathrm{ND}$ & 86 & ND & 2 & ND & 6 & $\mathrm{ND}$ \\
\hline \multicolumn{9}{|c|}{ Organochlorine compounds } \\
\hline Aldrin & 50 & ND & 86 & $D^{*}$ & 2 & ND & 18 & ND \\
\hline Chlordane & 50 & D & 84 & D & 2 & $\mathrm{D}$ & 18 & D \\
\hline DDD & 50 & ND & 86 & ND & 2 & ND & 18 & $D^{*}$ \\
\hline DDE & 50 & D & 86 & D & 2 & D & 18 & D \\
\hline DDT & 50 & ND & 86 & D & 2 & ND & 18 & D \\
\hline Dieldrin & 50 & D & 86 & D & 2 & ND & 18 & $D^{*}$ \\
\hline Endosulfan & 50 & D & 86 & D & 2 & ND & 18 & $D^{*}$ \\
\hline Endrin & 50 & ND & 86 & $D^{\star}$ & 2 & ND & 18 & ND \\
\hline \multirow{2}{*}{\multicolumn{9}{|c|}{ Heptachlor }} \\
\hline & & & & & & & & \\
\hline epoxide & 50 & ND & 86 & ND & 2 & ND & 18 & $\mathrm{D}$ \\
\hline Lindane & 50 & $\mathrm{D}$ & 86 & D & 2 & D & 18 & D \\
\hline Me thoxychlor & 50 & D & 86 & D & 2 & D & 18 & ND \\
\hline Mirex & 50 & ND & 86 & ND & 2 & ND & 18 & ND \\
\hline Perthane & 50 & ND & 86 & ND & 2 & ND & 18 & ND \\
\hline Toxaphene & 50 & ND & 86 & ND & 2 & ND & 18 & ND \\
\hline \multicolumn{9}{|c|}{ Organophosphorus compounds } \\
\hline Diazinon & 54 & $\mathrm{D}$ & 85 & $\mathrm{D}$ & 2 & $\mathrm{D}$ & 18 & $\mathrm{D}$ \\
\hline Ethion & 54 & $D^{*}$ & 86 & ND & 2 & ND & 18 & ND \\
\hline Malathion & 54 & $\mathrm{D}$ & 85 & $\mathrm{D}$ & 2 & $\mathrm{D}$ & 18 & $\mathrm{D}$ \\
\hline Methyl parathion & 54 & $D^{*}$ & 85 & $D^{*}$ & 2 & ND & 18 & ND \\
\hline Methyl trithion & 54 & ND & 86 & ND & 2 & ND & 18 & ND \\
\hline Parathion & 54 & $\mathrm{D}$ & 85 & D & 2 & ND & 18 & D \\
\hline Trithion & 54 & ND & 86 & ND & 2 & ND & 18 & ND \\
\hline \multicolumn{9}{|c|}{ Carbamate insecticides } \\
\hline Methomy1 & 10 & ND & 27 & ND & - & - & - & - \\
\hline Propham & 10 & ND & 27 & ND & - & - & - & - \\
\hline Sevin & 10 & ND & 27 & ND & - & • & • & • \\
\hline \multicolumn{9}{|c|}{ Chlorophenoxy acid herbicides } \\
\hline $2,4-D$ & 44 & D & 84 & $\mathrm{D}$ & 2 & ND & 8 & ND \\
\hline $2,4-D P$ & 44 & ND & 84 & ND & 2 & ND & - & - \\
\hline $2,4,5-T$ & 44 & ND & 84 & ND & 2 & ND & . & - \\
\hline Silvex & 44 & ND & 84 & D & 2 & ND & • & . \\
\hline
\end{tabular}

*Detected for only one sample. 
Table 34. Statistical summary of pesticides detected in rainfall samples

[Mean and standard deviation determined if all values were greater than or equal to the detection limit. Pesticide values are shown in micrograms per liter. <, actual value is less than value shown. ., not calculated]

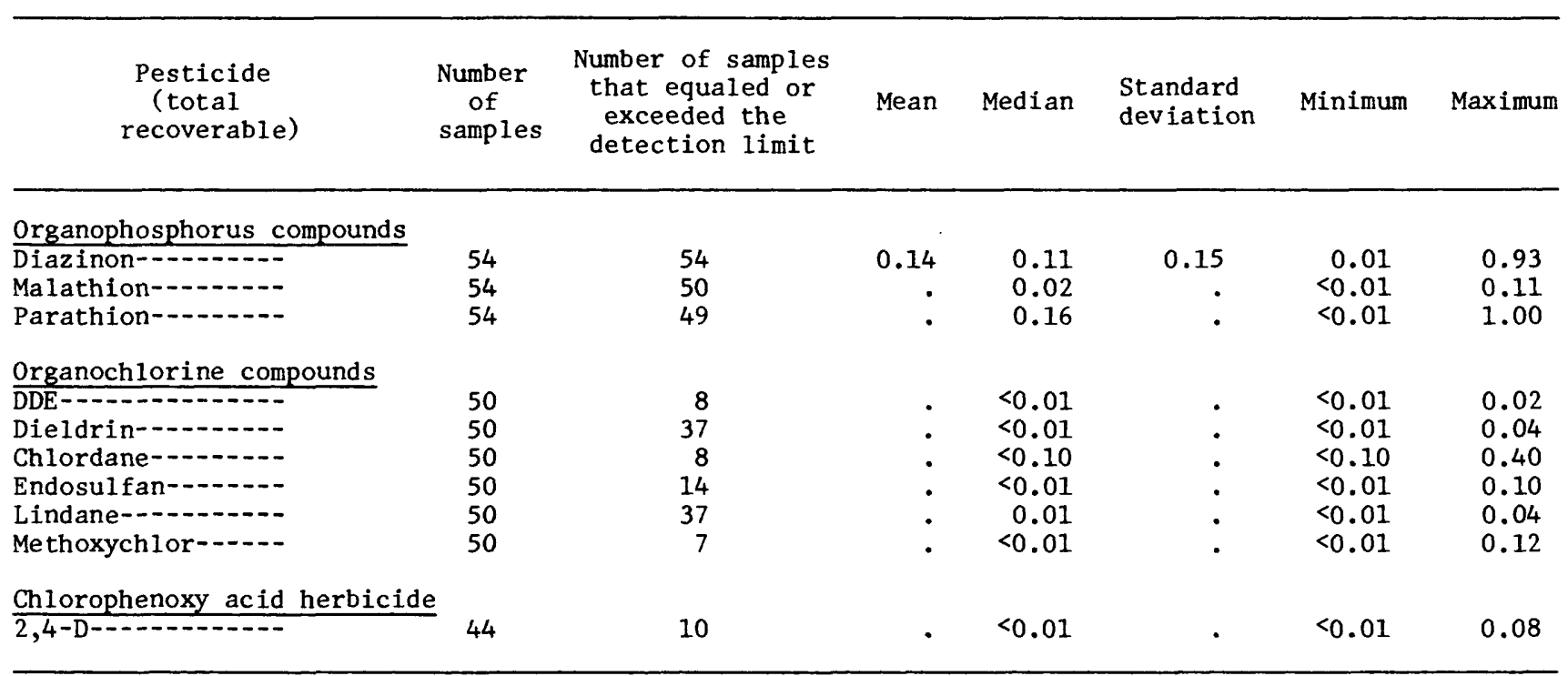


Table 35. Statistical summary of most frequently detected pesticides in runoff for each catchment

[Mean and standard deviation determined if all values were greater than or equal to the detection limit. Pesticide values are shown in micrograms per liter., <actual value is less than value shown. ., not calculated]

\begin{tabular}{|c|c|c|c|c|c|c|}
\hline $\begin{array}{l}\text { Pesticide } \\
\text { (total } \\
\text { recoverable) }\end{array}$ & $\begin{array}{l}\text { Number } \\
\text { of } \\
\text { samples }\end{array}$ & $\begin{array}{l}\text { Number of samples } \\
\text { that equaled or } \\
\text { exceeded the } \\
\text { detection limit }\end{array}$ & Mean & $\begin{array}{l}\text { Standard } \\
\text { deviation }\end{array}$ & Minimum & Maximum \\
\hline \multicolumn{7}{|c|}{ Industrial catchment } \\
\hline \multicolumn{7}{|l|}{ Organophosphorus compounds } \\
\hline $\begin{array}{l}\text { Parathion } \\
\text { Diazinon } \\
\text { Malathion }\end{array}$ & $\begin{array}{l}18 \\
18 \\
18\end{array}$ & $\begin{array}{r}5 \\
18 \\
18\end{array}$ & $\begin{array}{l}0.67 \\
0.66\end{array}$ & $\begin{array}{l}0.71 \\
0.67\end{array}$ & $\begin{array}{r}<0.01 \\
0.20 \\
0.20\end{array}$ & $\begin{array}{r}0.38 \\
3.3 \\
3.0\end{array}$ \\
\hline \multicolumn{7}{|l|}{ Organochlorine compounds } \\
\hline $\begin{array}{l}\text { Chlordane } \\
\text { Lindane }\end{array}$ & $\begin{array}{l}19 \\
19\end{array}$ & $\begin{array}{r}5 \\
19\end{array}$ & 0.05 & $0.0 \dot{6}$ & $\begin{array}{r}<0.10 \\
0.01\end{array}$ & $\begin{array}{l}0.30 \\
0.27\end{array}$ \\
\hline \multicolumn{7}{|l|}{ Chlorophenoxy acid herbicide } \\
\hline $2,4-D$ & 19 & 14 & - & - & $<0.01$ & 3.2 \\
\hline \multicolumn{7}{|c|}{$\underline{\text { Single-dwelling residential catchment }}$} \\
\hline \multicolumn{7}{|l|}{ Organophosphorus compounds } \\
\hline $\begin{array}{l}\text { Parathion } \\
\text { Diazinon } \\
\text { Malathion }\end{array}$ & $\begin{array}{l}16 \\
16 \\
16\end{array}$ & $\begin{array}{l}13 \\
16 \\
16\end{array}$ & $\begin{array}{r}0.3 \dot{6} \\
2.2\end{array}$ & $\begin{array}{r}0.27 \\
3.3\end{array}$ & $\begin{array}{r}<0.01 \\
0.11 \\
0.19\end{array}$ & $\begin{array}{r}0.92 \\
1.1 \\
13\end{array}$ \\
\hline $\begin{array}{l}\text { Organochlorine compounds } \\
\text { Chlordane } \\
\text { Lindane }\end{array}$ & $\begin{array}{l}16 \\
16\end{array}$ & $\begin{array}{l}16 \\
16\end{array}$ & $\begin{array}{l}0.16 \\
0.03\end{array}$ & $\begin{array}{l}0.07 \\
0.02\end{array}$ & $\begin{array}{l}0.10 \\
0.01\end{array}$ & $\begin{array}{l}0.30 \\
0.06\end{array}$ \\
\hline \multicolumn{7}{|l|}{ Chlorophenoxy acid herbicide } \\
\hline $2,4-D$ & 16 & 14 & - & - & $<0.01$ & 1.7 \\
\hline \multicolumn{7}{|c|}{ Multiple-dwelling residential catchment } \\
\hline \multicolumn{7}{|l|}{ Organophosphorus compounds } \\
\hline $\begin{array}{l}\text { Parathion } \\
\text { Diazinon } \\
\text { Malathion }\end{array}$ & $\begin{array}{l}27 \\
27 \\
27\end{array}$ & $\begin{array}{l}16 \\
27 \\
27\end{array}$ & $\begin{array}{r}0.68 \\
1.3\end{array}$ & $\begin{array}{r}1 . \dot{5} \\
2.6\end{array}$ & $\begin{array}{r}<0.01 \\
0.06 \\
0.08\end{array}$ & $\begin{array}{r}2.5 \\
8.1 \\
14\end{array}$ \\
\hline \multicolumn{7}{|l|}{ Organochlorine compounds } \\
\hline $\begin{array}{l}\text { Chlordane } \\
\text { Lindane } \\
\text { Chlorophenoxy acid herbicide }\end{array}$ & $\begin{array}{l}26 \\
27\end{array}$ & $\begin{array}{l}21 \\
22\end{array}$ & $\dot{.}$ & $\dot{\cdot}$ & $\begin{array}{l}<0.10 \\
<0.01\end{array}$ & $\begin{array}{r}1.2 \\
0.03\end{array}$ \\
\hline $2,4-D$ & 26 & 21 & - & - & $<0.01$ & 3.7 \\
\hline \multicolumn{7}{|c|}{ Commercial catchment } \\
\hline \multicolumn{7}{|l|}{ Organophosphorus compounds } \\
\hline $\begin{array}{l}\text { Parathion } \\
\text { Diazinon } \\
\text { Malathion }\end{array}$ & $\begin{array}{l}24 \\
24 \\
24\end{array}$ & $\begin{array}{l}17 \\
24 \\
24\end{array}$ & $\begin{array}{r}1 . \dot{6} \\
0.28\end{array}$ & $\begin{array}{r}3 . \dot{7} \\
0.25\end{array}$ & $\begin{array}{r}<0.01 \\
0.13 \\
0.08\end{array}$ & $\begin{array}{r}0.90 \\
18 \\
1.4\end{array}$ \\
\hline \multicolumn{7}{|l|}{ Organochlorine compounds } \\
\hline $\begin{array}{l}\text { Chlordane } \\
\text { Lindane }\end{array}$ & $\begin{array}{l}23 \\
24\end{array}$ & $\begin{array}{l}15 \\
23\end{array}$ & $\dot{.}$ & $\dot{.}$ & $\begin{array}{l}<0.10 \\
<0.01\end{array}$ & $\begin{array}{l}0.30 \\
0.03\end{array}$ \\
\hline Chlorophenoxy acid herbicide & & & & & & \\
\hline $2,4-D$ & 23 & 13 & - & - & $<0.01$ & 0.63 \\
\hline
\end{tabular}

